\title{
HYDROLOGY OF AREA 50, NORTHERN GREAT PLAINS AND \\ ROCKY MOUNTAIN COAL PROVINCES, \\ WYOMING AND MONTANA
}

BY

MARLIN E. LOWRY, JAMES F. WILSON, JR., AND OTHERS

U.S. GEOLOGICAL SURVEY

WATER-RESOURCES INVESTIGATIONS

OPEN-FILE REPORT 83-545

CHEYENNE, WYOMING

OCTOBER, 1986 


\title{
UNITED STATES DEPARTMENT OF THE INTERIOR
}

\author{
DONALD PAUL HODEL, SECRETARY
}

\section{GEOLOGICAL SURVEY}

Dallas. L. Peck, Director

For additional information write to:

District Chief

U.S. Geological Survey

Water Resources Division

P.O. Box 1125

Cheyenne, Wyoming 82003 


\section{CONTENTS}

Abstract 1

1.0 Introduction. .2

1.1 Objective 2

Frederick A. Kilpatrick and Marlin E. Lowry

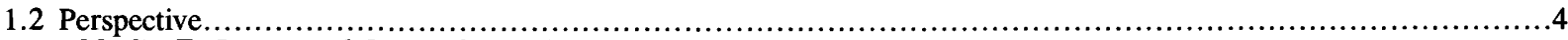

Marlin E. Lowry and James G. Rankl

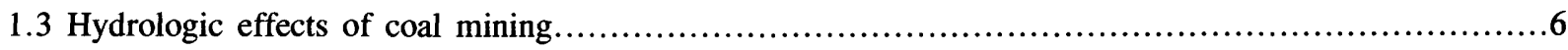

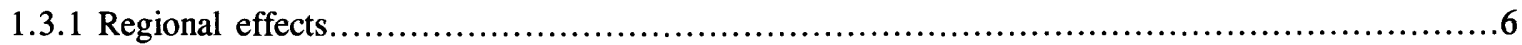
Marlin E. Lowry

1.3.2 Local effects. .8 Marlin E. Lowry

2.0 Definition of terms.

3.0 Physiography

3.1 Climate

H. W. Lowham

3.2 Landforms. 14

James G. Rankl

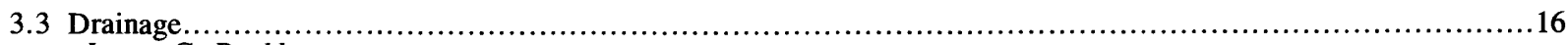

James G. Rankl

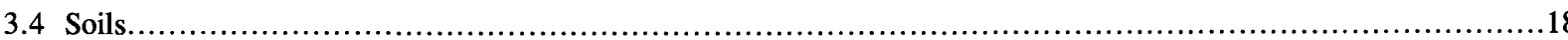

James G. Rankl

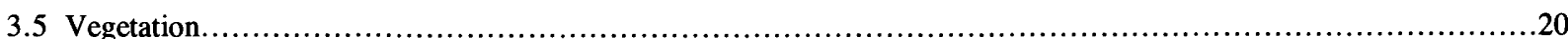

David A. Peterson

3.6 Geology

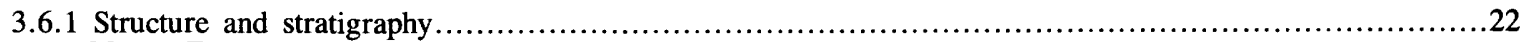
Marlin E. Lowry

3.6.2 Surficial geology

Marlin E. Lowry

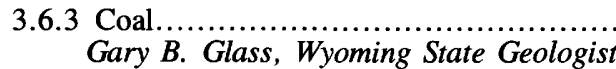

4.0 Economic development

4.1 Surface ownership. 28

David A. Peterson and Marlin E. Lowry

4.2 Minerals ownership

Marlin E. Lowry

4.3 Land and water use. David A. Peterson

4.4 Coal

Gary B. Glass, Wyoming State Geologist

4.5 Other mineral resources.

Marlin E. Lowry (U.S. Geological Survey) and Alan J. Ver Ploeg

and Ray E. Harris (The Geological Survey of Wyoming) 
$H$. W. Lowham and L. R. Larson

6.0 Surface-water quantity

6.1 Average flow... James G. Rankl and Gerald W. Armentrout, Jr.

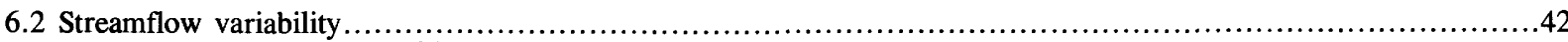
James G. Rankl and Gerald W. Armentrout, Jr.

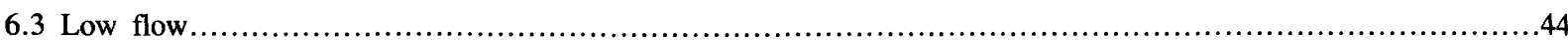
James G. Rankl and Gerald W. Armentrout, Jr.

6.4 Floods

6.4.1 Occurrence.

Gerald W. Armentrout, Jr.

6.4.2 Peak-flow frequency... James F. Wilson, Jr.

6.4.3 Hydrographs-small streams. James F. Wilson, Jr.

6.4.4 Flood-prone area maps.

Gerald W. Armentrout, $J r$.

6.5 Relationship to ground water.

James G. Rankl and Marlin E. Lowry

7.0 Surface-water quality

7.1 Chemical quality

7.1.1 Dissolved solids.

L. R. Larson

7.1.2 Seasonal variability

L. R. Larson

7.1.3 Alkalinity

$$
\text { L. R. Larson }
$$

$7.1 .4 \mathrm{pH}$

L. R. Larson

7.1.5 Ionic composition

7.1.6 Total phosphorus

$$
\text { L. R. Larson }
$$

7.1.7 Trace metals L. R. Larson

7.2 Suspended sediment

7.2.1 Concentration.

Bruce H. Ringen

7.2.2 Loads-Powder River.

Bruce H. Ringen

7.2.3 Loads-Belle Fourche and Cheyenne Rivers

Bruce H. Ringen 
7.3 Biology

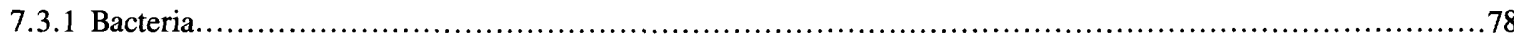

David A. Peterson

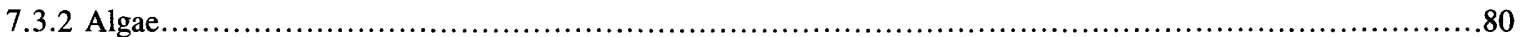

David A. Peterson

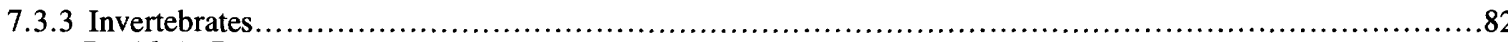

David A. Peterson

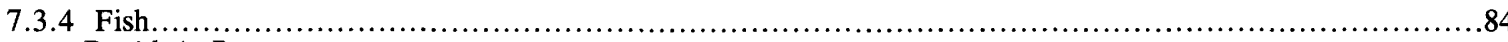

David A. Peterson

7.4 Temperature.

H. W. Lowham

8.0 Ground water

8.1 Ground-water data.

Marlin E. Lowry

8.2 Availability

Marlin E. Lowry

Pamela B. Daddow

8.4 Chemical quality

8.4.1 Dissolved solids

L. R. Larson

8.4.2 Trace metals

L. R. Larson

8.4.3 Ground-water-quality controls. Marlin E. Lowry

9.0 Water-data sources

9.1 Introduction

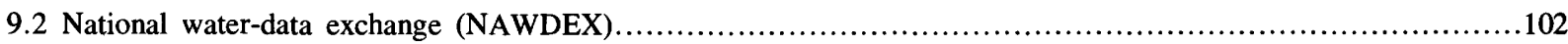

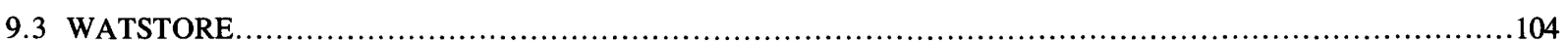

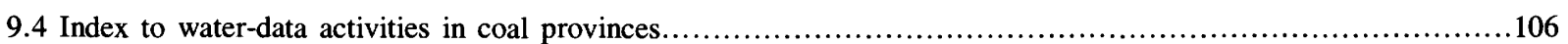

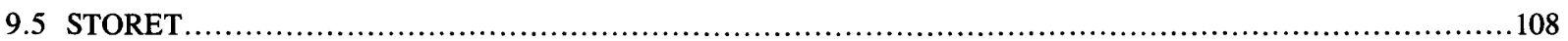

10.0 Supplemental information for Area 50

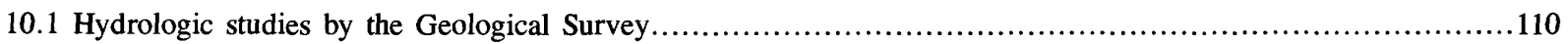

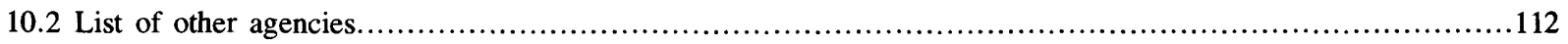

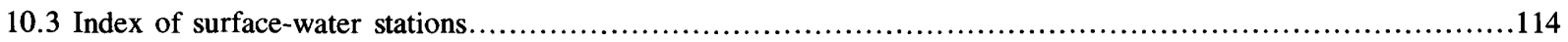

11.0 References

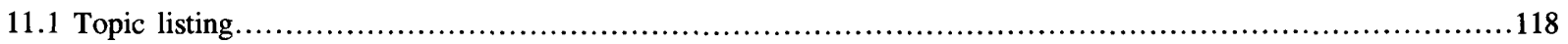

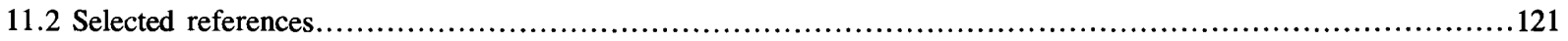




\section{FACTORS FOR CONVERTING INCH-POUND UNITS TO INTERNATIONAL SYSTEM OF UNITS (SI)}

\section{For the convenience of readers who may want to use the International System of Units (SI), the data may be converted by using the following factors:}

\begin{tabular}{|c|c|}
\hline Multiply & By \\
\hline acre & 4,047 \\
\hline acre-foot (acre-ft) & 1,233 \\
\hline acre-foot per square mile (acre $\mathrm{ft} / \mathrm{mi}^{2}$ ) & 476 \\
\hline British thermal unit per pound (BTU//b) & 2.326 \\
\hline cubic foot $\left(\mathrm{ft}^{3}\right)$ & 0.02832 \\
\hline cubic foot per second $\left(\mathrm{ft}^{3} / \mathrm{s}\right)$ & 0.02832 \\
\hline $\begin{array}{l}\text { cubic foot per second per } \\
\text { square mile }\left[\left(\mathrm{ft}^{3} / \mathrm{s}\right) / \mathrm{mi}^{2}\right]\end{array}$ & 0.01093 \\
\hline foot $(\mathrm{ft})$ & 0.3048 \\
\hline foot per mile $(\mathrm{ft} / \mathrm{mi})$ & 0.1894 \\
\hline gallon per minute (gal $/ \mathrm{min}$ ) & 0.06309 \\
\hline gallon per second (gal/s) & 3.785 \\
\hline inch (in.) & 25.40 \\
\hline mile (mi) & 1.609 \\
\hline million gallons per day (Mgal/d) & $\begin{array}{l}0.04381 \\
3.785\end{array}$ \\
\hline pound (lb) & 453.6 \\
\hline pound per cubic foot $\left(\mathrm{lb} / \mathrm{ft}^{3}\right)$ & 16.02 \\
\hline square foot $\left(\mathrm{ft}^{2}\right)$ & 0.09290 \\
\hline square mile $\left(\mathrm{mi}^{2}\right)$ & 2.590 \\
\hline ton (short, 2,000 pounds) & 0.9072 \\
\hline ton per day (ton/d) & $\begin{array}{l}0.0105 \\
0.9072\end{array}$ \\
\hline
\end{tabular}

To obtain
square meter
cubic meter
cubic meter per square kilometer
joule per gram
cubic meter
cubic meter per second
cubic meter per second
square kilometer
meter
meter per kilometer
liter per second
liter per second
millimeter
kilometer
cubic meter per second
cubic meter per day
gram
kilogram per cubic meter
square meter
square kilometer
metric ton
kilogram per second
metric ton per day

Temperature can be converted to degrees Fahrenheit $\left({ }^{\circ} \mathrm{F}\right)$ or degrees Celsius $\left({ }^{\circ} \mathrm{C}\right)$ by the following equations:

$$
\begin{aligned}
& { }^{\circ} \mathrm{F}=9 / 5\left({ }^{\circ} \mathrm{C}\right)+32 \\
& { }^{\circ} \mathrm{C}=5 / 9\left({ }^{\circ} \mathrm{F}-32\right)
\end{aligned}
$$

National Geodetic Vertical Datum of 1929 (NGVD of 1929): A geodetic datum derived from a general adjustment of the first-order level nets of both the United States and Canada, formerly called mean sea level. NGVD of 1929 is referred to as sea level in this report. 


\section{HYDROLOGY OF AREA 50, \\ NORTHERN GREAT PLAINS AND \\ ROCKY MOUNTAIN COAL PROVINCES, WYOMING AND MONTANA}

MY

\section{Abstract}

Area 50 includes the entire Powder River Basin and the upstream parts of the Belle Fourche and Cheyenn tion in this report will be useful to Federal agencies in leasing and management of Federal coal lands, to surfacemine owners, operators and others preparing permit appents a summary of the restis to date report repreresources investigations of the U.S. Geological Survey, conducted in cooperation with State and other Federa agencies.

The area has abundant deposits of coal, but water is scarce. Increased population, industrial development, an water-based recreation are expected to have a much greater impact on water resources than the mining and transporta-
tion of the coal. However, the most likely effect of reclamation will be to inset into the existing hydrologic system a unit having hydrologic properties that are completely different from the undisturbed bedrock and overdetrimental in others.

The climate is semiarid in most of the area. The terrain varies from forested mountains to sand dunes, bu semiarid plains and the tablelands near the center of the area. Ephemeral and interrupted streams drain 80 percent
of the area and yield 40 percent of the runoff. Soils of the plains cover 94 percent of the area. In the plains areas a mixture of grasses and sagebrush are the predo
vegetation; trees are scarce except in the mountains.

The area coincides approximately with the Powder periods are present; the coal was deposited during the Cretaceous and Tertiary Periods. Most coal beds are
within the Fort Union and Wasatch Formations. The within the Fort Union and Wasatch Formations. The
near-surface deposits generally are nearly flat-lying and near-surface deposits generally are nearly flat-lying and
uninterrupted by major faults. The average thickness of the coal bed being mined during 1983 was 70 feet. Nearly all of the near-surface coals are of subbituminous rank,
averaging about 8,000 British thermal units per pound averaging about 8,000 British thermal units per pound,
with about 0.5 percent sulfur content. State and Federal governments own less than one-half of the land surface;
however, the Federal government owns most of the coal.
Nearly 90 percent of the land is used for agricultura purposes-mostly livestock grazing; 92 percent of the wat esulted in intense competition between agriculture and industry for land and water.

All active coal mining in the area is in the outcrop of ng. Annual coal production has increased from less than million tons in 1970 to 81.2 million tons in 1982; the projected production in 81.2 is 122 million tons. Other um, bentonite, gypsum, limestone, and metals. gas, uran-

Surface-water data are available for 168 locations on streams in Area $50 ; 132$ have streamflow data, 81 have
chemical-quality data, 42 have fluvial-sediment data, and 67 have biological data. In mountain areas average-annual runoff exceeds 200 acre-feet per square mile; in the plain areas it is less than 10 acre-feet per square mile. Mos

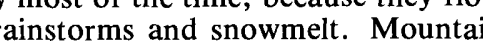
streams seldom go dry.

Intense summer thunderstorms cause most of the the common cause of floo, while rapid spring snowmelt is taneous flooding on all streams in the area is rare. Values of the 100-year floods are available for 37 stations; graph ites and a procedure is described for synthesizing hydrographs for small streams. Analysis of streamflow and water-level data indicates that discharge to streams from local ground-water systems is
regional ground-water system.

Average dissolved-solids concentrations are significantly greater than the national secondary drinking-wate 00 milligrams per liter in samples at nearly one-half of the stations. Dissolved-solids concentration generally vary seasonally with stream discharge. Strean Average concentrations in the Belle Fourche River are
significantly smaller downstream from Keyhole Reservoi than upstream.
Average alkalinity concentrations exceed 100 milligrams per liter at all sampling stations and 200 milligram per liter at host stations; the risk of acid mine drainage is of the area's streams is accompanied by uniformly capacily values-nearly all measurements are above 7 but less than 9 . Sodium and sulfate generally are the dominant ions, excep in mountain streams, in which calcium, magnesium, and end and magnesium are large enough
ever, to make the water very hard.

Total-phosphorus concentrations, associated with large concentrations of suspended sediment, are large average 0.58 milligrams per liter. Although the Belle Fourche River often has large concentrations of tota phosphorus, algal growth is not a problem in Keyhole area's streams; exceptions are large concentrations of selenium in the South Fork Powder River and large concen-
trations of manganese and iron in some samples throughtrations of $m$ out the area.
out

The discharge-weighted concentration of suspended sediment in the Powder River at Arvada, Wyoming wa year in contrast with an average of about 8000 milligam per liter for the 1979-80 water years. Sediment loads transported by the Powder River are large, eroded mostly from the Wyoming reach and partly deposited in the Fourche and Cheyenne Rivers, increase significantly in the downstream direction, and are trapped in Keyhole and Angostura Reservoirs. Clay-size particles comprise bet-
ween 38 and 97 percent of the sediment transported out of

Bacteria concentrations in streams are small throughout the area, indicating little pollution from warm-bloode ous species of algae in many streams indicate some enrichment--probably the result of natural conditions and waste from livestock and wildlife.

The invertebrate communities in Clear Creek downstream from Buffalo and in Donkey Creek downstream from Gillette reflect degradation of the water by sewage
effluent. In the Belle Fourche River, invertebrate com作 from a coal mine as upstream. Invertebrates also can be
used to indicate relative volume and pattern of streamflow.
Trout and other cold-water game fish are found in , but generally not plains streams; catfish, bass, and o the coal mines are nut not in mountain streams. Most of that do not support a fishery resource; the Little Powder exception.

Stream temperature affects rates of chemical reactions range from 0 degrees Celsius (32 degrees Fahrenheit) in winter to about 25 degrees Celsius (77 degrees Fahrenheit) summer.

Ground-water data--water levels, well yields, and water quality-are available for about 3,000 wells in Area
50 . Water levels in 800 wells completed in the WyodakAnderson coal were collected during 1981 by mining comdata for the coal and overburden in the mine areas of Campbell County, Wyoming.

Ground-water supplies suitable for stock and domestic use can be developed from wells less than 500 feet deep in most of the area. Deeper wells generally are needed to considered where large supplies are sought; however, because the permeability of the formation is principally charge to aquifers occurs mainly in the outcrop areas nea their southern, western, and eastern extents. Small quantiMadison and Lower Cretaceous aquifers. Movement in the coal aquifers is complex.

Eighty-four percent of the wells and springs sampled
ineld water with dissolved-solids concentrations greater than the recommended national secondary drinking-wate standard of 500 milligrams per liter. Nearly all sources sampled, however, yield water suitable for livestock. Maners are large enough to be objectionable for domestic supplies because of taste and staining problems. The chemical quality of the ground water is controlled by the solubility of the minerals that comprise the rocks, the water temperature and $\mathrm{pH}$, and the length of time during which the water is in contact with the rocks. 
1.0 INTRODUCTION

1.1 Objective

\section{Report Summarizes Available Hydrologic Data}

Existing hydrologic conditions and sources of hydrologic information are

identified to aid in the preparation and appraisal of environmental impact
studies and mine-permit applications and in making leasing decisions.

Hydrologic information and analyses are needed 0 aid in making decisions to lease Federally owned ronmental assessments and impact study This need has become even more critical with the enactment of Public Law 95-87, "Surface Mining Control and Reclamation Act of 1977". This Act requires an appropriate regulatory agency to issue mining permits partly on the basis of the assessment of the hydrologic impacts in the mining-permit application. This need is partly fulfiled by a series of reports that broadly characterize the hydrology of This report is part of that series. A similar report is available for Area 49, which is adjacent to the northwestern border of Area 50 (Slagle and others, 1983).

Area 50 includes the entire Powder River drainage basin and he upstream parts of the Belle Fourche and Cheyenne River basins. The Powder River drainage basin does not coincide with the Powder River structural basin (fig. 1.1-1). Most of Area 50, which includes 20,676 square miles in Montana and Province; the remainder is in the Rocky Mountain Coal Province.

This report provides general hydrologic information by means of a brief text with accompanying map, chart, graph, or other illustration, for each of a series of water-resources-related topics. Collectively the topical discussions represent a deschiption of the hydrology of the area. The information contained hend mall be useful to Fedral agel lands, to susace mine owners, operators, and others preparing permit

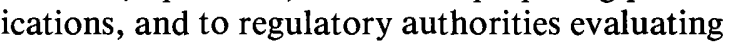
the adequacy of the applications.

The hydrologic information presented herein or available through sources identified in this report will be useful in describing the hydrology of the "general area" of any proposed mine. This hydrologic information will be supplemented by the lease applicant's site-specific data as well as data from other sources.
Site-specific data are used for a detailed appraisal of the hydrology of the area in the vicinity of the mine and to determine the anticipated hydrologic consequences of the mining operation.

This report represents a summary of the results ions to date in northeastern Wyoming and southeastern Montana. The U.S. Geological Survey has collected hydrologic data and made interpretive hydrologic studies in the area for decades. Much of the work has been done in cooperation with State and other Federal agenciesparticularly the Wyoming State Engineer, Wyoming Department, Wyoming Department of Environmental Quality, Montana Bureau of Mines and Geology, Montana Department of Natural Resources and Conservation, U.S. Bureau of Land Management, U.S. Army Corps of Engineers, U.S. Environmental Protection Agency, and U.S. Department of Energy. To a large extent this cooperation has been responsible for achieving the present state of knowledge of the hydrology of Area so and will be an important 


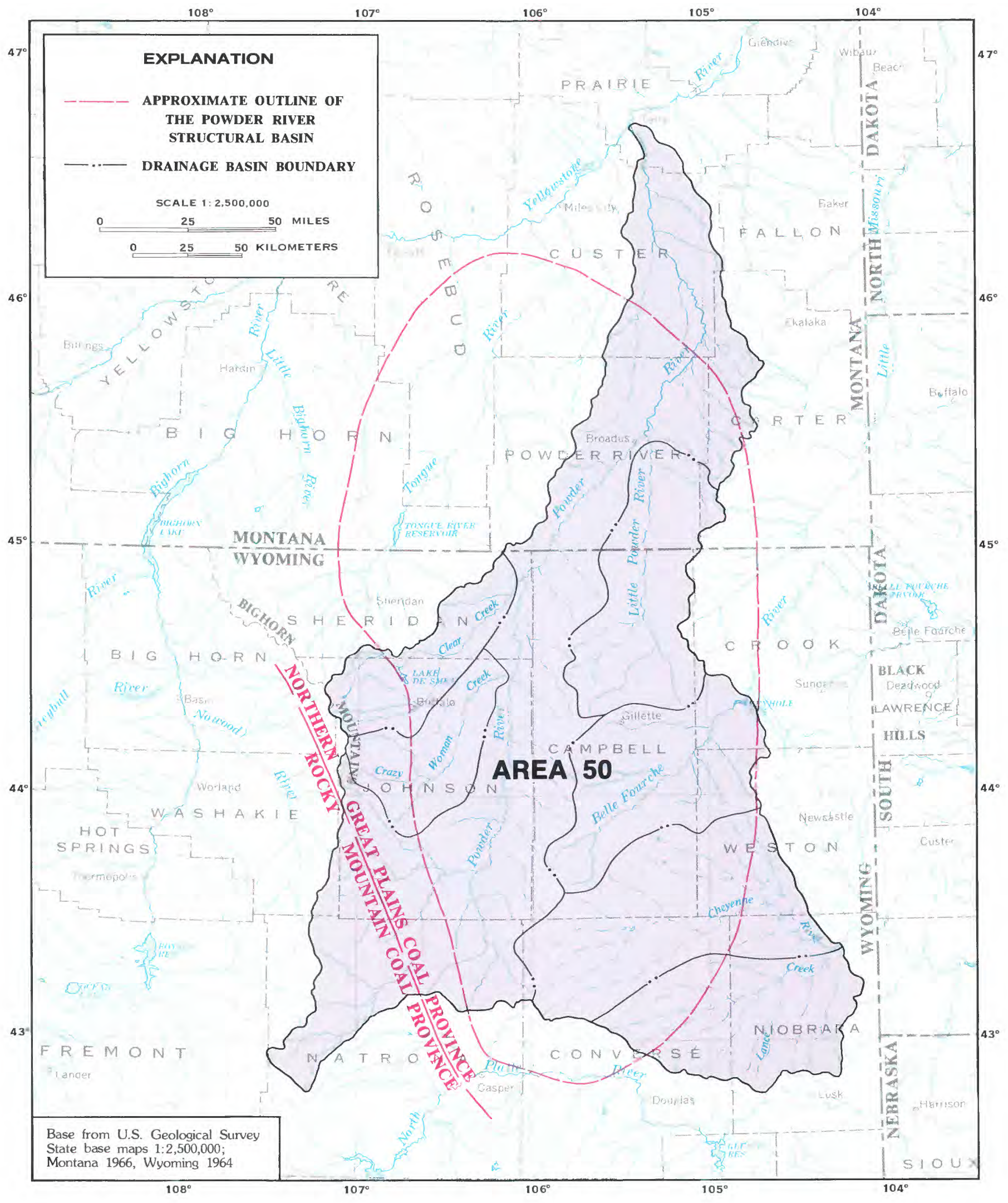

Figure 1.1-1 Location of Area 50 and the Powder River Structural basin. 


\title{
1.0 INTRODUCTION--Continued \\ 1.2 Perspective
}

\section{Abundant Coal, Scarce Water}

\author{
Development of the area's vast coal deposits spans nearly a century, but \\ modern development is significantly affected by the scarcity of water.
}

The Powder River indirectly was named because of the coal in the area. Fires, generally caused by spontaneous combustion, have burned extensive areas, leaving baked and fused red rock that is locally called clinker or scoria. The Raynolds survey of 1859 reported, "*** Powder River, (which derives its name from the sulphurous vapors rising from burning beds of lignite in its vicinity,) ***" (Raynolds, 1868, p. 8).

The coal resources captured the imagination of some on the earliest expeditions into the area. One of the first recorded proposals for development of the coal and water in the Lake De Smet area is given in Palmer's account of the expedition of Connor in 1865, where he suggested the following: "Seven miles from Clear Fork we came to a very pretty lake, about two miles long and about three-fourths of a mile wide, which Major Bridger told us was De Smet Lake, named for Father De Smet. The lake is strongly impregnated with alkali, in fact so strong that an egg or potato will not sink if thrown into the water; large red bluffs are to be seen on both sides, and underneath the lake is an immense coal vein. Not many miles from this lake is a flowing oil well. A scheme might be inaugurated to tunnel under this lake, pump the oil into the lake, set the tunnel on fire and boil the whole body of alkali water and oil into soap. ${ }^{1}$ Lake De Smet has since been developed into an off-stream reservoir and still is prominant in plans for the development of the 200 -foot coal bed that partly underlies the lake.

"The Virginian" of Owen Wister's novel of the same name, who was the prototype for western heroes, also had plans for coal development in the Powder River Basin. The Virginian planned for the changes in ranching which he envisioned and said, "I am well fixed for the new conditions. And then, when I took up my land, I chose a place where there is coal. It will not be long before the new railroad needs that." (Wister, 1902, p. 433).
Although the area has abundant coal, little water is readily available to develop the coal and to supply the resulting increased population. Area $50 \mathrm{com}$ prises about 2 percent of the area of the Mississippi drainage basin, but contributes only about 0.1 percent of the flow to the Mississippi River. The quotations on the facing page (fig. 1.2-1) emphasize that coal is abundant, water is deficient, and although there is a need for development, care is needed to develop the resources wisely.

The shortage of water for energy development in the area is perhaps best shown by two projects, the 330,000-kilowatt Wyodak steam-electric powerplant and the Energy Transportation Systems Incorporated (ETSI) proposed coal-slurry pipeline. The Wyodak plant is the world's largest (1983) air-cooled, steamelectric plant. The decision for building an aircooled system, which requires a larger capital investment and is less efficient than water-cooled systems, was made because of the abundance of coal and the scarcity of water. The 200 to 300 gallons of water per minute required by the plant is principally effluent from the Gillette sewage-treatment facility.

The ETSI slurry pipeline was originally intended to use ground water to transport pulverized coal from the Powder River Basin to Arkansas. The use of ground water was approved by the Wyoming Legislature in 1974. The ensuing battle, often emotional and sometimes bitter, centered on two issues: the transport of "scarce" Wyoming water, via the pipeline, to other States; and the alleged potential for lowering water levels in western South Dakota. The State of South Dakota threatened legal action against the State of Wyoming if ground water were used for the coal slurry. Present (1983) plans are to obtain water for the slurry line by building a pipeline from the Oahe Reservoir, which is on the Missouri River in South Dakota. This plan is being opposed in the courts by States downstream from the reservoir.

\footnotetext{
${ }^{1}$ Quoted text reprinted with permission of the publishers, The Arthur H. Clark Company, from Powder River Campaigns and Sawyer Expedition of 1865, edited by L. R. Hafen and A. W. Hafen (1961, p. 124).
} 
"AND YET, ANCIENT AS ARE THE ORIGINS OF THESE FOUNDATIONS OF OUR CURRENT PROSPERITY THE REMARKABLE THING IS THAT THE PROVSION FO THEIS BOUN OF OUR CUNET HAS BEEN SUCH EARLY NINETEENTH CENTURY THAN THERE WAS BETWEEN THAT ERA AND THE PERIOD OF THE LIFE OF CHRIST. THE REASON FOR THIS IS THE INCREASINGLY SUCCESSFUL EXPLOITATION OF THE CRUST OF THE PLANET ON WHICH WE LIVE. LIFE EXPECTANCY AS RECORDED IN ONE OF THE OLDER CENSUSES BASED ON SWEDEN IN THE MIDDLE OF THE 18TH CENTURY WAS 19 YEARS IN TOWNS AND VILLAGES. IN THOSE SAME PLACES, IT IS NOW 70 YEARS AND THE DIFFERENCE THAT HAS ARISEN IN THAT BRIEF TIME SPAN RESULTS FROM FOUR PARTICULAR DISCOVERIES AND APPLICATIONS: MEDICAL CARE, AND ADEQUATE DIET, CLEAN WATER SUPPLIES, AND AN EFFECTIVE SYSTEM OF WASTE DISPOSAL. AND ALL THOSE THINGS ULTIMATELY DEPEND UPON MATERIALS PROVIDED BY THE SURFACE OF THE PLANET ON WHICH WE LIVE.

THE DEVELOPMENT DURING THE THT AND 18 TH CENTURIES OF CHEAP AND THE INVENTON OF THE BAST FURNACE TO PRODUCE INEXPENSIVE IRON AND STEE AEALIZE THE TOTALTY OF OUR DEPENDENCE ON THE EARTH THE BULLDINGS IN WHCH WE LIVE ARE BUILT OF MATERIAL MANUFACTURED FROM THE EARTH'S CRUST. HEATING, COOLING, AND LIGHTING SYSTEMS INVOLVE THE USE OF ENERGY DERIVED FROM MATERIALS IN THE CRUST, ENERGY STORED FROM THE SUN BY PLANTS AND ANIMALS MILLIONS OF YEARS AGO. MOST OF THE CLOTHING WE WEAR, THE FOOD WE EAT, GASOLINE, CARS, RADIO, TV-ALL THESE ARE TRIUMPHS OF EXTRACTION OF CRUDE MATERIALS FROM THE CRUST OF THE EARTH; DULL, UNPROMISING ROCKLIKE MANUFACTURED INTO SOMETHING OF IMMEDIATE VALUE.

FOR SOME OF OUR MOST ESSENTIAL COMMODITIES-OIL, GAS, MERCURY, TIN,

ES DWINDLE

YET DEMAND INCREASES. OUR NONREPLENISHABLE RESOURCES, OUR BURGEONING

RHODES AND STONE (1981 P. 357-350) WITH PERMISSIC

\section{WORLD COAL RESOURCE STANDINGS}

2) RUSSIA

3) UNITED STATES

5) CAMPBELL COUNTY, WYOMING-IF IT WERE AN INDEPENDENT COUNTRY

\section{GARY B. GLASS, WYOMING STATE GEOLOGIST}

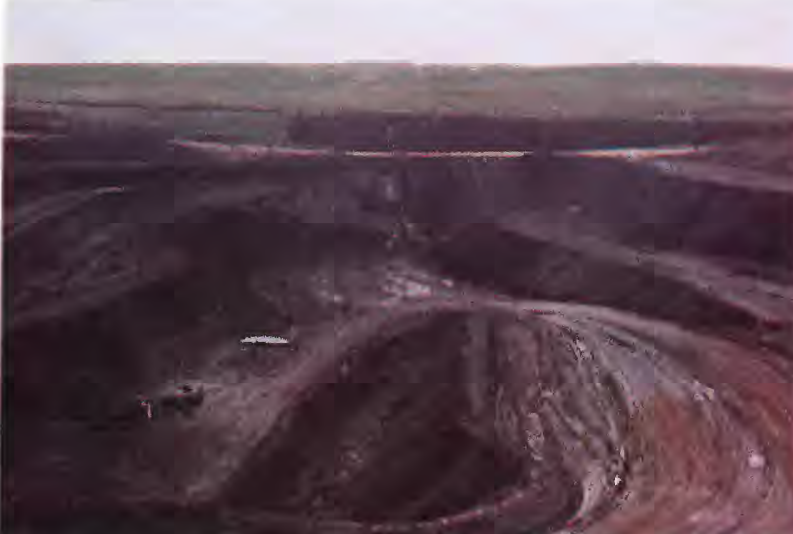
Photograph by Susan
Enoming Department of
Environmental Quality

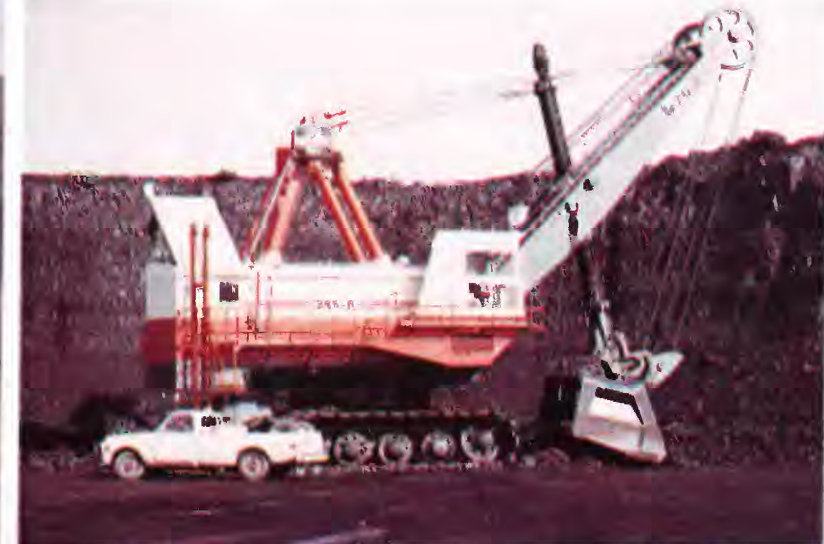

Photograph by R. Rothschadl
U. S. Bureau of Land Management

The Wyodak coal bed in Campbell County, Wyoming has an average thickness of about 70 feet, with 5 to 50 feet of overburden.

IN SUMMARY, THERE IS PROBABLY SUFFICIENT SURFACE WATER IN THE UPPER MISSOURI BASIN TO SUPPORT FULL ENFRGY DEVELPMENT (IF, SYNFUFLS, COAL-FIRED GENERATING PLANTS, SLURRY PIPELINES). ACTUAL DEVELOPMENT, HOWEVER, WOULD NECESSIATE LARGE SCALE DIVERSIONS WITHIN THE BASIN WHICH WILL RESULT IN MANY EMOTIONAL, POLITICAL, AND LEGAL REPURCUSSIONS. *** THE NEXT FEW DECADES WILL BE CRITITCAL FOR THE WATER RESOURCES OF THE UPPER MISSOURI BASIN. THE IMPENDING ENERGY DEMAND MUST BE MANAGED WITH CARE. SENSTIVTY AND TECHNCAL IANOVATHON TO AVOD A TOTAL DISTRUPTION OF THE HYDROGEOLOGY OF THE AREA." 


\title{
1.0 INTRODUCTION--Continued
}

1.3 Hydrologic Effects of Coal Mining

1.3.1 Regional Effects

\section{Increased Population, Not Mining, Will Have Largest Hydrologic Impact}

\author{
Water development for the increased population, industrial development, and \\ water-based recreation may result in greatest hydrologic impacts.
}

The largest impact on the hydrology probably will be caused by the increases in population and land use, rather than actual mining activities. The largest increase in population because of coal development has been and will continue to be in Campbell County, Wyo., but adjoining service areas will have significant increases also. The population trends for Gillette and Campbell County, Wyo., are shown in figure 1.3.1-1. Water for municipal use is projected to increase from 3,990 acre-feet per year during 1975 to 11,290 acre-feet per year by 1990 (U.S. Department of the Interior, 1979d, p. R1-19). Use of water for coal mines is projected to increase, in the same period, from 170 to 3,500 acre-feet per year. Waterbased recreation will increase more than 100 percent. As of March 1983 no complaints had been filed with the Office of the Wyoming State Engineer about effects of coal mining on water resources. However, ground water for individual domestic supplies, trailer courts, and housing developments was being developed to such a large extent that the State Engineer started an investigation in the summer of 1982 (Richard G. Stockdale, Office of the Wyoming State Engineer, oral commun., 1983).

Because the area is semiarid, water supplies from outside the area will have to be developed; the impacts of such development will extend beyond Area 50. The City of Gillette has developed water from the Madison Limestone, about 40 miles northeast of the town, to meet the increased demand for municipal supplies. Most water-based recreation is outside Area 50.

The impacts on hydrology of the different alternatives for coal conversion in the area and for transporting coal from the area differ, but some alternatives would cause larger hydrologic impacts than actual mining. A comparison of the impacts of four coal-use processes using $\mathbf{1 2 . 5}$ million tons of coal per year on selected aspects of the environment for the Colorado part of the Yampa River basin is reproduced in table 1.3.1-1. Although these are not the only possible alternatives, the table indicates that hydrologic impacts are largely dependent on coal-use processes and on population. This table is used, rather than data for projects proposed in the area, because it is based on a common coal tonnage for comparison.

Airborne residuals may enter the hydrologic cycle either by washout, by precipitation, or by direct settling on the surface and later being incorporated in runoff. There are proposals to dispose of solid residuals in surface mines; therefore, some residue could enter the ground-water system.

The scale of planned mining of the WyodakAnderson coal bed is large; therefore, some areal hydrologic consequences of mining will occur. It can be assumed that eventually the strippable coal will be mined and that such large-scale mining will have an impact on the hydrology. An example of what could happen to drainage in surface-mined areas is shown in figure 1.3.1-2. Surface-mining regulations preclude the drastic change in drainage illustrated. However, the reclaimed spoil will have different hydrologic properties from the undisturbed bedrock. Also, it will not always be possible, nor necessarily desirable, to re-establish the original topography. Although infiltration, runoff, and aquifer properties can be engineered in a variety of ways, the most likely effect of reclamation will be to inset into the existing hydrologic system a unit having completely different hydrologic properties. The changes could be beneficial or detrimental, or beneficial to some and detrimental to others. For example, if infiltration were increased, less runoff would flow to streams. During intervals of low flow, this decrease could have an adverse impact on downstream users; during floods the decrease could lessen the possibility of flooding and could benefit downstream landowners.

The impact of mining on ground water has caused some concern. Regionally, however, there probably will be no measureable impact on the quantity of flow because flow is dominantly local, rather than regional, in the upper several hundred feet of the coal-bearing rocks. The possible impacts on quality of water have not been adequately assessed. 


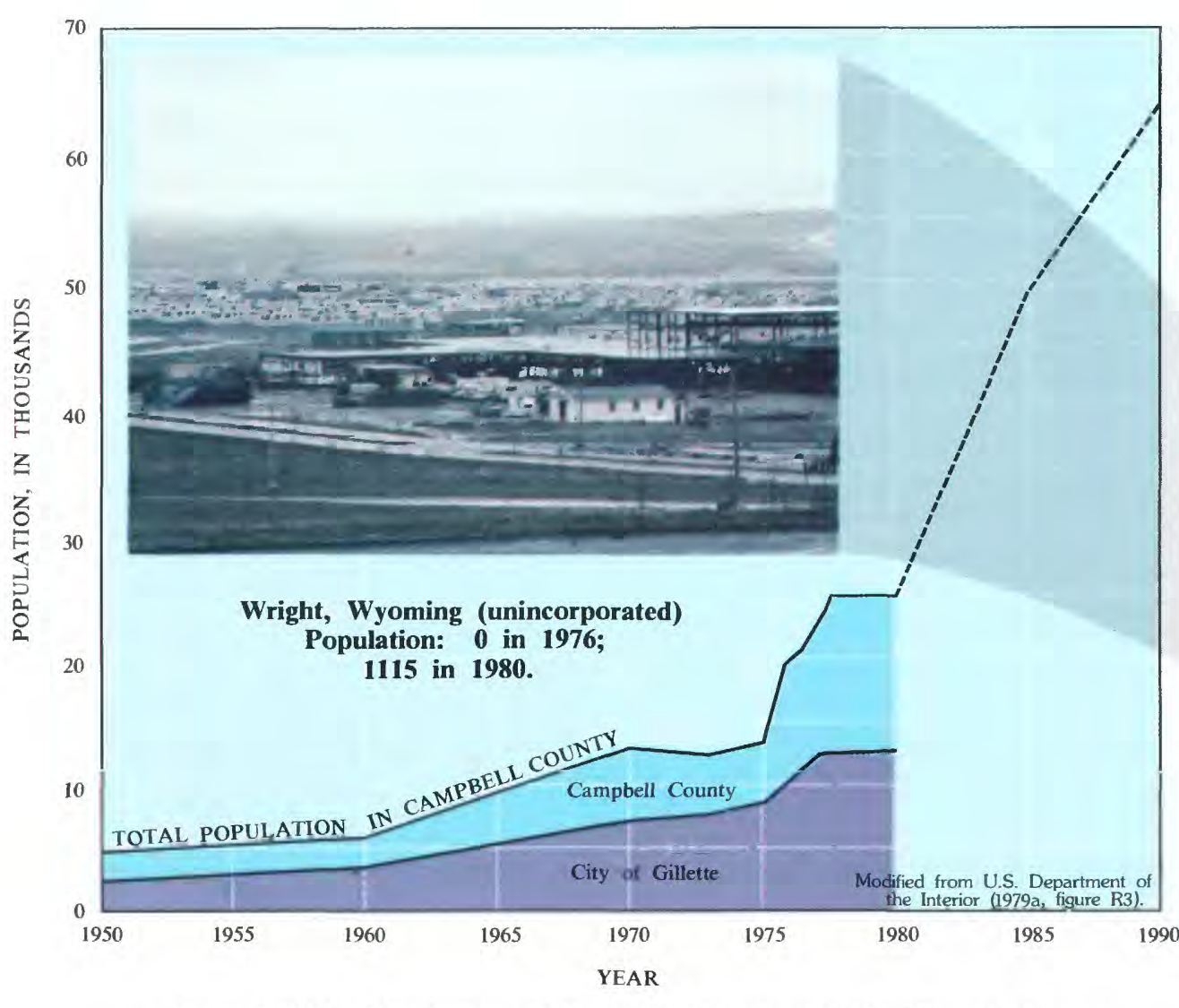

Figure 1.3.1-1 Population of Campbell County and the City of Gillette, 1950-80, and projected population of Campbell County, 1980-90.

Table 1.3.1-1 Comparison of the impact.of four alternative coal-use processes
on selected aspects of the environment, Colorado part of the Yampa River basin.

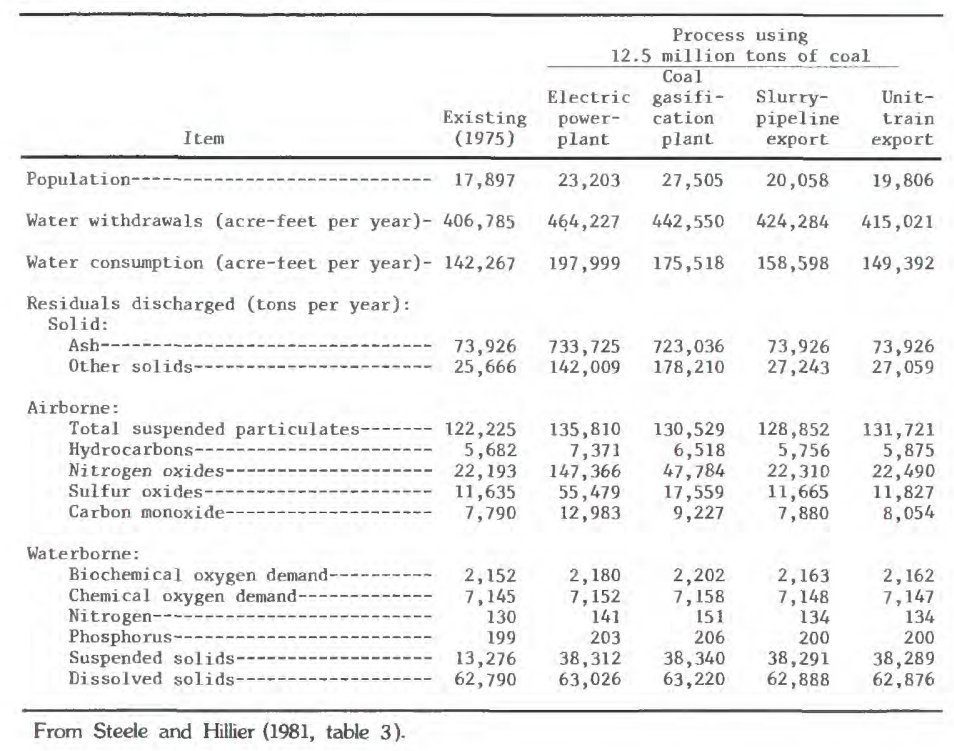

From Steele and Hilier (1981, table 3)

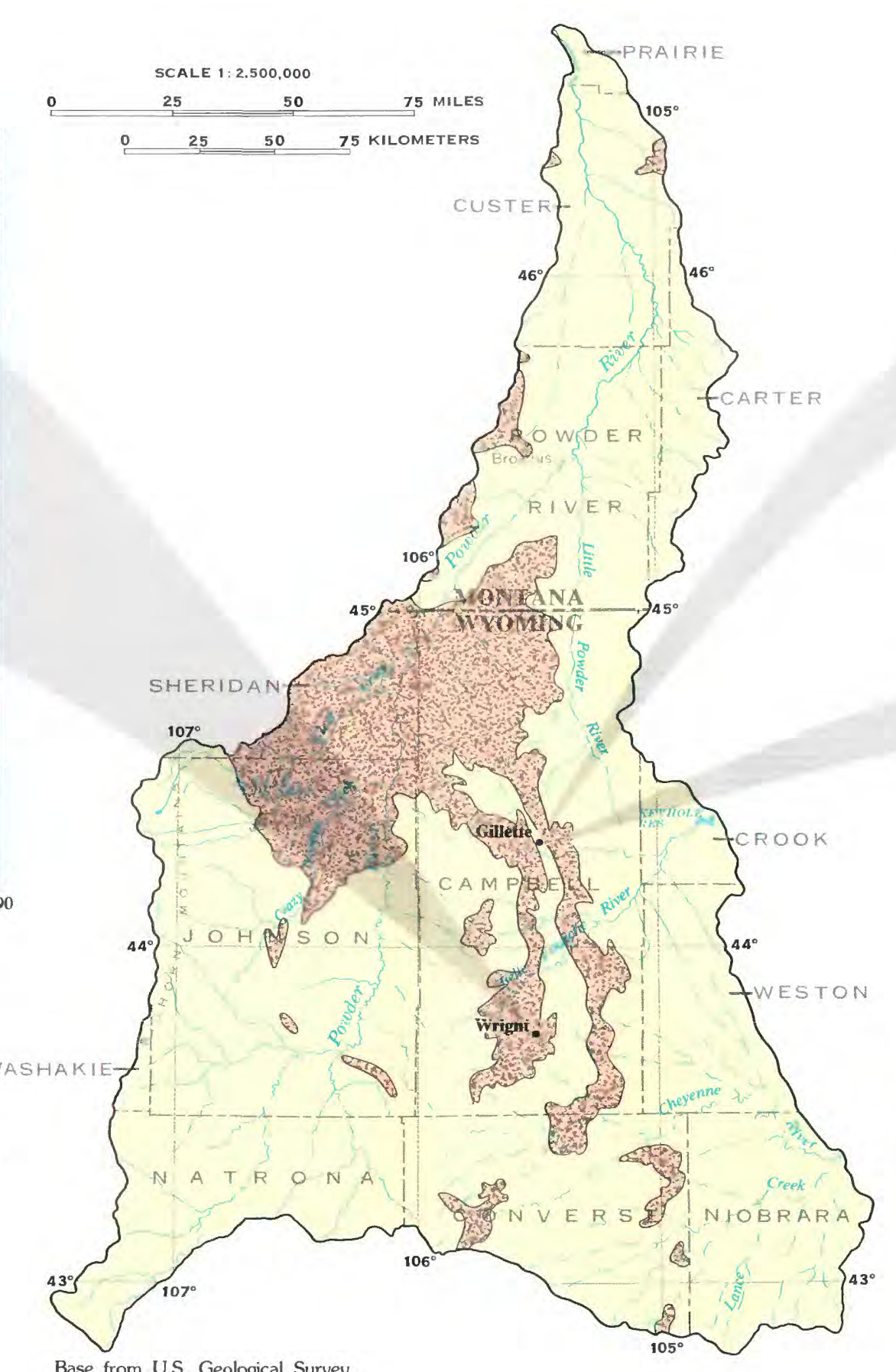

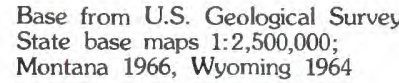

EXPLANATION

TRE. AREA WITH IDENTIFIED, NEAR-SURFACE,

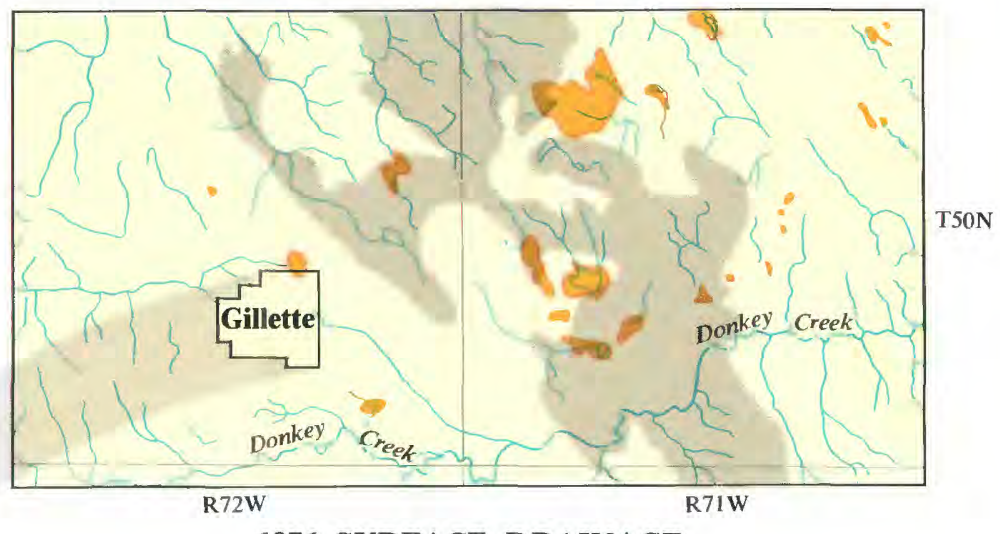

1976 SURFACE DRAINAGE

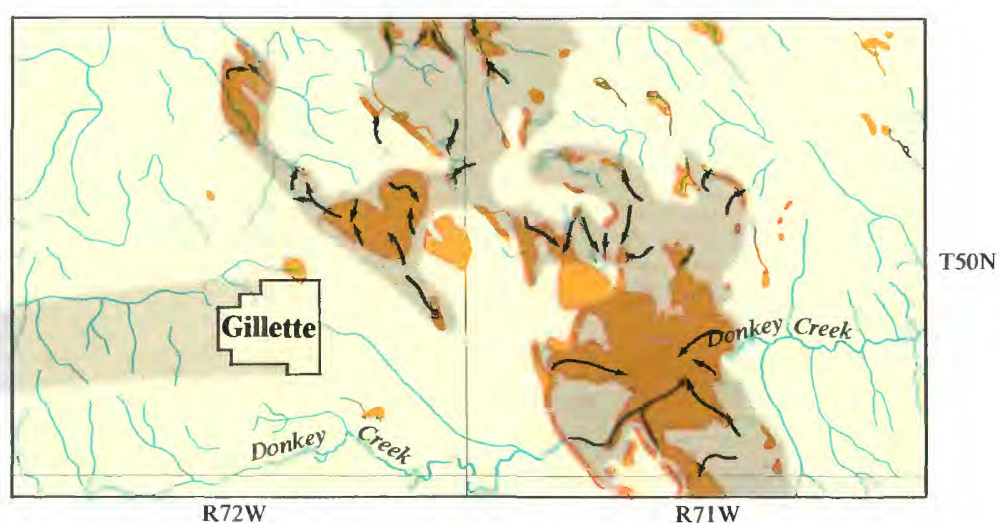

RECONSTRUCTED SURFACE DRAINAGE

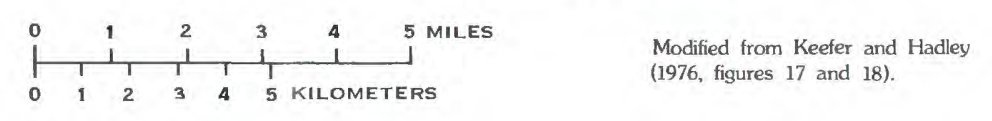

Figure 1.3.1-2 1976 surface drainage, Gillette and vicinity, and reconstructed surface drainage, if all coal is extracted from the strippable zone of the Wyodak-Anderson deposit according to the following assumed methods of mining and reclamation. 1) Overburden is replaced on a cut-by-cut basis as mining proceeds from east to west on $200-$-foot-wide north
trending panels; 2) spoils are smoothly graded; 3) high walls are graded to $3: 1$ slopes; 4) overburden swells 20 percent; and 5) no attempt is made to re-establish through-flowing drainage. Strippable coal zone is shown by grey area
tract are shown by yellow-range area. Arrows indicate direction of streamflow. Based on a detailed of the post-mining terrain by FR. Shawe (U.S. Geological Survey, written commun., 1975).
All drainoge are internitent except phats of D.onkey Crek shown as heayy lines 


\title{
1.0 INTRODUCTION--Continued \\ 1.3 Hydrologic Effects of Coal Mining-Continued 1.3.2 Local Effects
}

\section{Some Hydrologic Effects Beneficial; Some Detrimental}

\author{
Water from mines may be developed for beneficial use; however, water levels \\ will be lowered in the undisturbea cloal and overburden and may never recover \\ to pre-mining levels.
}

Water from some surface and underground mines has been developed for beneficial use. The water discharged from a mine into a stream at times may be the only flow in a stream and may have less dissolved solids than normal flow; such water commonly is put to beneficial use by ranchers in the area. The hydrographs in figure 1.3.2-1 illustrate flow in the Belle Fourche River upstream and downstream from the Cordero Mine in response to rainfall and snowmelt runoff and flow at the downstream site beginning in late August as the result of pumping from the mine. The bar graph shows that the water pumped from the mine contained less dissolved solids than are present in water during periods of normal flow.

Large amounts of water accumulate in abandoned coal mines and this water has been developed from springs at old mine entrances and from wells bored into flooded mine workings (Lowry and Cummings, 1966, p. 40). (See figure 1.3.2-2.) A mined area to the west of Area 50 has flooded and has been stocked with trout and bass by the Wyoming Game and Fish Department.

There are many different hydrologic settings where coal may be mined. Therefore, local hydrologic effects of mining cannot be generalized for Area 50. In applying for a mining permit, the operators of a proposed mine are required to describe the local hydrologic effects of mining and reclamation methods they intend to use.

Changes in hydrology will occur because of the changes in the physical conditions caused by mining.
These can be broadly classed into the effects on quantity and quality of ground and surface water in time and in space. The only effect that will certainly result is: where surface mining begins at the edge of the coal and extends some distance beyond the point where the water table is intercepted, the water levels in adjoining aquifers will be permanently lowered. There may or may not be other significant effects.

To date, the lowering of water levels has not been severe. Richard Stockdale, Hydrologist for the Office of the Wyoming State Engineer (oral commun., Mar. 1983), states that his office has received no complaints of water-level decline as the result of surface mining of coal. Since extensive mining began in mid-1970's, the lowering of water levels may not have extended beyond the mine property. However, the lowering of the water level near the Wyodak Mine, which began operation in the 1920 's, has not extended westward more than 1,600 feet (Everett, 1979 , p. 157). The lowering of the water level at the west face of the north pit probably is about 100 feet.

There has not been, nor is there presently planned (1983), large-scale underground mining in Area 50. The mine previously mentioned from which water has been developed by wells, the Krezlock Mine, produced only about 19,000 tons of coal between 1919 and 1950 (Mapel, 1959, p. 92). However, in the Tongue River basin, adjacent to Area 50, underground mining was extensive prior to 1950 and subsidence has occurred in many areas (Dunrud and Osterwald, 1980). Hydrologic effects of underground mining in Area 50 have not been described. 

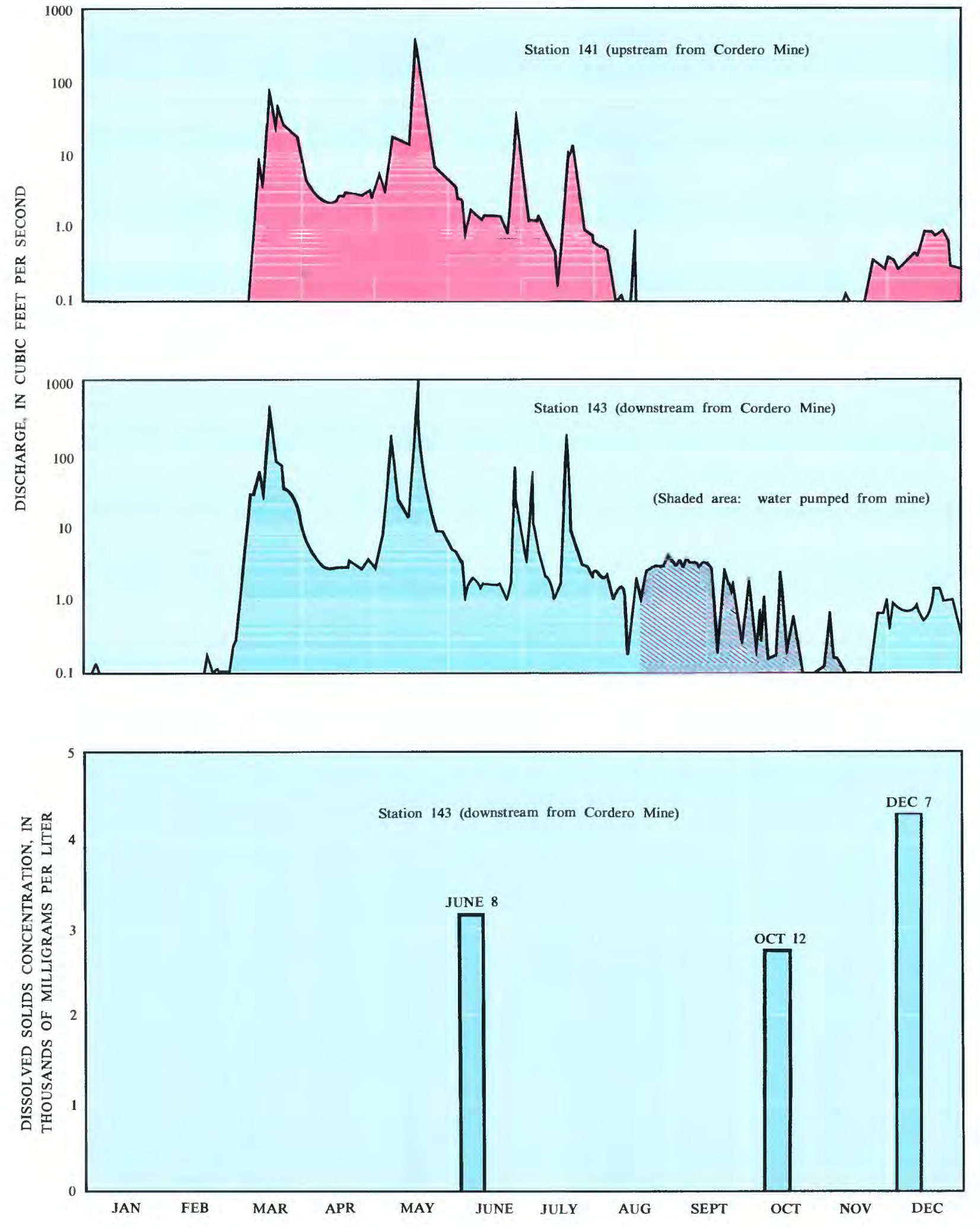

Figure 1.3.2-1 Daily discharge and dissolved solids of water in the Belle Fourche River, 1978

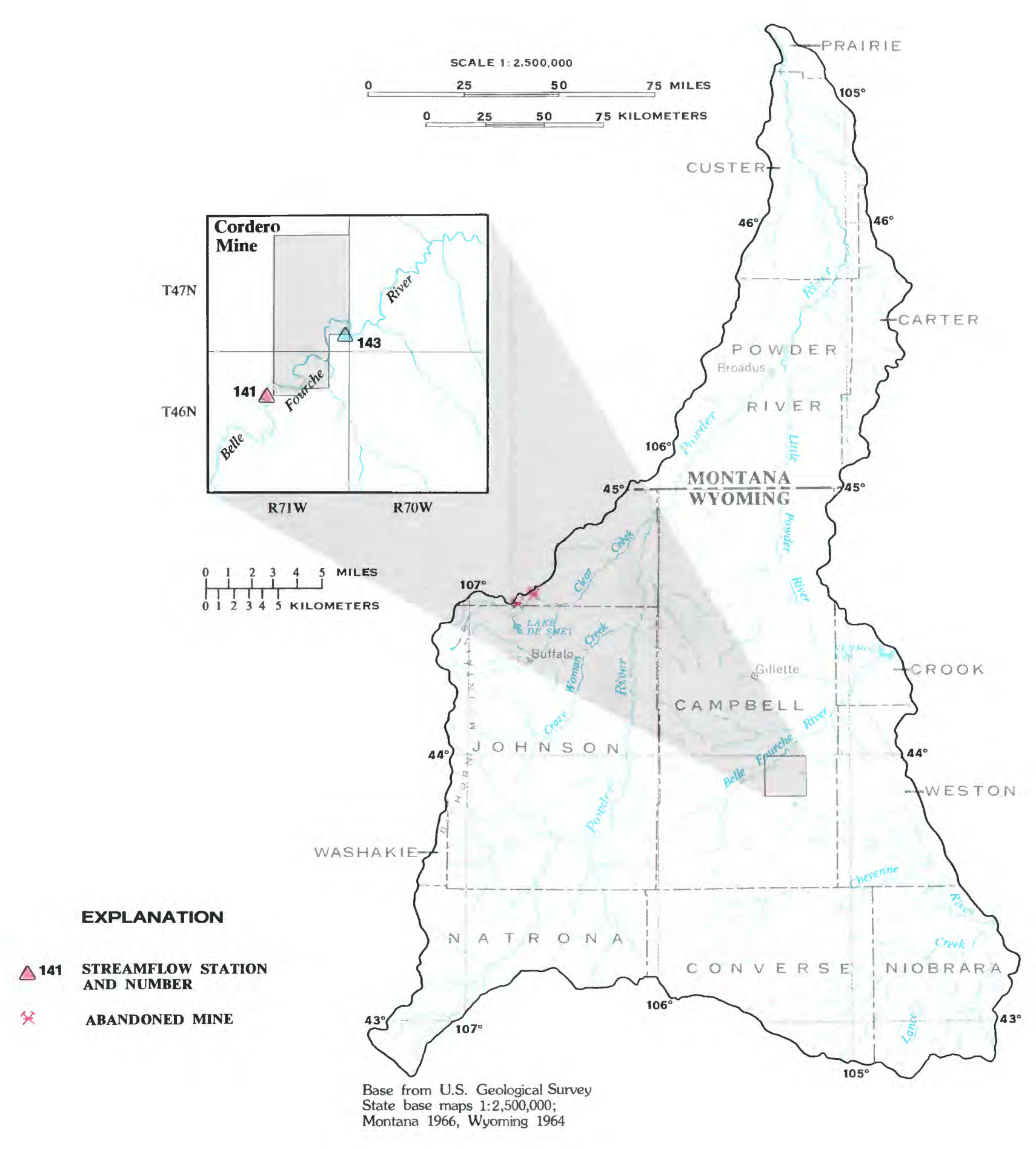

Location of stations 141 and 143 and location of abandoned mines where water supplies have been developed. 


\subsection{DEFINITION OF TERMS}

\section{Terms in Report Defined}

\section{Technical terms that occur in this hydrologic report are defined}

Algae are single-celled, colonial, or multi-celled plants, containing chlorophyll and lacking roots, stems, and leaves.

Blue-green algae are a Division (Cyanophyta) of phytoplankton organisms having a blue pigment, in addition to the green pigment called chlorophyll. Bluegreen algae commonly cause nuisance conditions in water.

Diatoms are the unicellular or colonial algae having a siliceous shell. Diatoms comprise most of the Division Chrysophyta. Their concentrations are expressed as number of cells per milliliter of sample.

Euglenoids are a Division (Euglenophyta) of algae commonly associated with organic wastes in water. Their concentrations are expressed as number of cells per milliliter of sample.

Green algae have chlorophyll pigments similar in color to those of higher-order green plants. Some forms produce algal mats or floating "moss" in lakes. Their concentrations are expressed as number of cells per milliliter of sample.

Alluvium is clay, silt, sand, gravel, or similar detrital material deposited by flowing water.

Aquifer is a geologic formation, group of formations, or part of a formation that contains sufficient saturated permeable material to yield significant quantities of water to wells and springs.

Base flow is sustained or fair-weather runoff. In most streams, base flow is composed largely of ground-water effluent. The term base flow is often used in the same sense as base runoff (see Langbein and Iseri, 1960).

Cubic foot per second $\left(\mathrm{ft}^{3} / \mathrm{s}\right)$ is the rate of discharge representing a volume of 1 cubic foot passing a given point during 1 second and is equivalent to approximately 7.48 gallons per second or 448.8 gallons per minute or 0.02832 cubic meters per second.
Discharge is the volume of water (or more broadly, volume of fluid plus suspended material), that passes a given point within a given period of time.

Average discharge is the arithmetic mean of individual daily average discharges during a specific period.

Instantaneous discharge is the discharge at a particular instant of time.

Peak discharge (peak flow) is the maximum instantaneous discharge that occurs during a specified time interval. The series of annual peak discharges at a gaging station is used to determine the recurrence interval (frequency) and exceedance probability of floods.

Discharge-weighted concentration is the ratio of the total discharged dry weight of sediment, for a time period, to the total discharge by volume, for the same time period, of the water-sediment mixture, expressed as milligrams per liter.

Dissolved refers to the amount of substance present in true chemical solution. In practice, however, the term includes all forms of substance that will pass through a 0.45 -micrometer membrane filter, and thus may include some very small (colloidal) suspended particles. Analyses are performed on filtered samples.

Drainage area of a stream at a specific location is that area, measured in a horizontal plane, enclosed by a topographic divide from which direct surface runoff from precipitation normally drains by gravity into the river upstream from the specified point. Figures of drainage area given herein include all closed basins, or noncontributing areas, within the area unless otherwise noted.

Drainage basin is a part of the surface of the Earth that is occupied by a drainage system, which consists of a surface stream or body of impounded surface water together with all tributary surface streams and bodies of impounded surface water. 
Ephemeral stream is a stream that flows only in direct response to precipitation, and whose channel is at all times above the water table.

Evapotranspiration is water withdrawn from a land area by evaporation from water surfaces and moist soil and by plant transpiration.

Exceedance probability is the mathematical expre sion of the probability that a flood equal to or greater than a given magnitude will occur in any given year. It is the inverse of the recurrence interval. For example, a 100-year flood has an exceed
(1-percent chance in any year).

Flood is an overflow or inundation that comes from river or other body of water and causes or threatens damage; any relatively high streamflow overtopping the natural or artificial banks in any reach of a stream.

Fluvial sediment is sediment that is transported by, suspended in, or deposited from water.

Gage height is the water-surface elevation referred to some arbitrary gage datum. Gage height often is used athou with a reading on a gage.

Gaging station is a particular site on a stream, canal, lake or reservoir where systematic observations of hydrologic data are obtained.

Hydrograph is a graph showing stage, flow, velocity, or other property of water with respect to time.

Infiltration is the downward entry of water into the with piate surface of soil or other material, as contrasted soil layers or other surficial material.

Intermittent stream is a stream that flows only at certain times of the year when it receives water from springs
or from some surface source such as melting snow.

Interrupted stream is a stream that contains alternating reaches that are either ephemeral, intermittent, or perennial.

Micrograms per liter $(\mu \mathrm{g} / \mathrm{L})$ is a unit expressing the concentration of chemical constituents in solution as mass (micrograms) of solute per unit volume (ititer) of to 1 milligram per liter.
Milligrams per liter $(\mathrm{mg} / \mathrm{L})$ is a unit for expressing the lligrantration of chemical constituents in solution. volume (liter) of water. Concentration of suspended sediment also is expressed in milligrams per liter, and is based on the mass (dry weight) of sediment per liter of water-sediment mixture.

Parent material is the unconsolidated organic and bedrock is not parent material by this concept.

Particle size is the diameter, in millimeters, of any given sediment particle. It may be determined by sieve or sedimentation
classification.)

Particle-size classification is a system of dividing the sediment particles into groups, each group having minimum and maximum dimension limits. The classification used by the U.S. Geological Survey follows that used by the American Geophysical Union Subcom-
mittee on Sediment Terminology as follows:

\begin{tabular}{ccc} 
Classification & \multicolumn{2}{c}{$\begin{array}{c}\text { Dimension limits, } \\
\text { in millimeters }\end{array}$} \\
Clay & 0.00024 & -0.004 \\
Silt & 0.004 & 0.062 \\
Sand & 0.062 & 2.00 \\
Gravel & 2.00 & -64.0
\end{tabular}

Particle-size distribution is the proportion of material of each particle-size class present in a given sample.

Perennial stream is a stream that flows continuously.

Permeability is a measure of the relative ease with which a porous medium can transmit a liquid under
potential gradient.

Porosity is the property of a rock or soil that refers to the interstices or voids that the material contains. It may be expressed quantitatively as the ratio of the material.

Potentiometric surface is the surface defined by the level to which water will ise in tightly cased wells completed in an aquifer or in a stratum within an aquifer.

Recharge is the process by which water is absorbed and added to the saturated zone (an aquifer), either formation. Also, the quatity of water that is added to the saturated zone.
Recurrence interval is the average interval of time within which a flood of given magnitude will be equaled withed at a discharge that has a recurrence interval of 100 years. The recurrence interval is the inverse of the exceedance probability.

Sediment is fragmented solid material that riginates mostly from disintegrated rocks. It may also include chemical and biochemical precipitates and decomposed organic material, such as humus.

Site is a location on a stream where one or more miscer and samples collected. (See station.)

Specific conductance is a measure of the ability of water to conduct an electrical current. It is expressed in microsiemens per centimeter at 25 Celsius. Specific conductance is related to the type and concentration of ions in solution and can be used for approximating the dissolved-solids concentration of the water. Commonly, the concentration of dissolved solids (in milligrams per liter) is about 65 percent of the specific conductance (in to stream

Specific weight is the weight per unit volume of a substrate, such as sediment.

Stage-discharge relationship is the relation between ater, per unit of time flowing in a channel (discharge).

Station is a location on a stream where a continuous or repetitive record of streamflow and (or) water quality has been collected. (See site.)

Streamflow is the discharge that occurs in a natural channel. Although the term "discharge" can be applied
to a flow of a canal, the word "streamflow" uniquely describes the discharge in a surface stream course. The term "streamflow" is more general than "runoff" as it is affected by diver sion or regulation.

Sublimation is the process whereby snow is changed to water vapor without melting.

Substrate is the physical surface upon which an organism lives.

Suspended sediment is the sediment that at any given time is maintained in suspension by the upward components of turbulent currents or that exists in

Suspended-sediment concentration is the velocity weighted concentration of suspended sediment in the sampled zone (from the water surface to a point approxmately 0.3 foot above the bed) expressed as milligrams $(\mathrm{mg} / \mathrm{L})$.

Suspended-sediment discharge is the rate at which suspended sediment is transported through a cross secion of a stream.

Suspended-sediment load is the quantity of sediment that is transported through any cross section of a stream in a unit of time.

Terrace is a berm or discontinuous segments of a berm, in a valley at some height above the flood plain, representing a former abandoned flood plain of the stream.

Transmissivity is the rate at which water of the prevailing kinematic viscosity is transmitted through a fo the aquifer under a unit hydraulic gradient.

Turbidity is the optical property of a suspension with reference to the extent to which the penetration of light
is inhibited by the presence of insoluble material. 


\subsection{PHYSIOGRAPHY}

\section{Topography Affects the Climate}

Average precipitation in the mountains exceeds 25 inches per year; the plains receive 10 to 16 inches.

The climate of the area is affected significantly by the mountains along the Pacific cosst and the Rocky Mountains. Westerly winds prevail, and the air masses generally move into the area from the Pacific Ocean. The mountain ranges cause much of the moisture in the air to precipitate before reaching the area. Continental air masses from Canada occasionally move into the area. place, forcing it upward and thus causing snow.

The distribution of average annual precipitation is shown in figure 3.1-1. Most precipitation from November through April occurs as snow. Annual 100 inches or greater in the mountains. Much of the snow in the open plains is sublimated; some snow remains a drifts in draws and shaded areas. Precipitation during the summer occurs as light showers and occasional intense thunderstorms. The distribution of normal monthly precipitation at two National WW

The amount of precipitation that occurs each year is extremely variable. During 1936-75, the weathe station at Arvada $3 \mathrm{~N}$ recorded an annual maximum of 7.0 inches during 1966. During 1923-79, the station Midwest $1 \mathrm{SW}$ recorded an annual maximum of $19.8 \mathrm{in}$ ches during 1972 and an annual minimum of 8.4 inches during 1951 .
Normal air temperature is minimum during late January and is maximum during late July. Average monthly air temperatures at Arvada $3 \mathrm{~N}$ and Midwest $1 \mathrm{SW}$ are shown in figure 3.1-2. Soil temperatures at a depth of 6 feet vary much less than air temperatures;
the change in soil temperature lags changes in the air temperature by about 1 month.

Evapotranspiration is greatest during July, but continues to be significant well into the fall because of possible on an annual basis, ranging from apout 55 percent possible during winter to about 75 percent during late summer.

Wind is significant to the climate, with westerly winds prevailing. Wind velocity averages about 13 miles per hour annually, ranging farm an average of 10 miles per hour during July and August to an average of 16 miles per hour during November through April. Daytime winds genally are stonger than casional storns cause brief periods

The foregoing description of climate is based on a report prepared by J. D. Alyea (written commun., 1980. tional Oceanic and Atmoblished monthly by the $\mathrm{Na}$ tional Climatic Center, Asheville, N.C. 


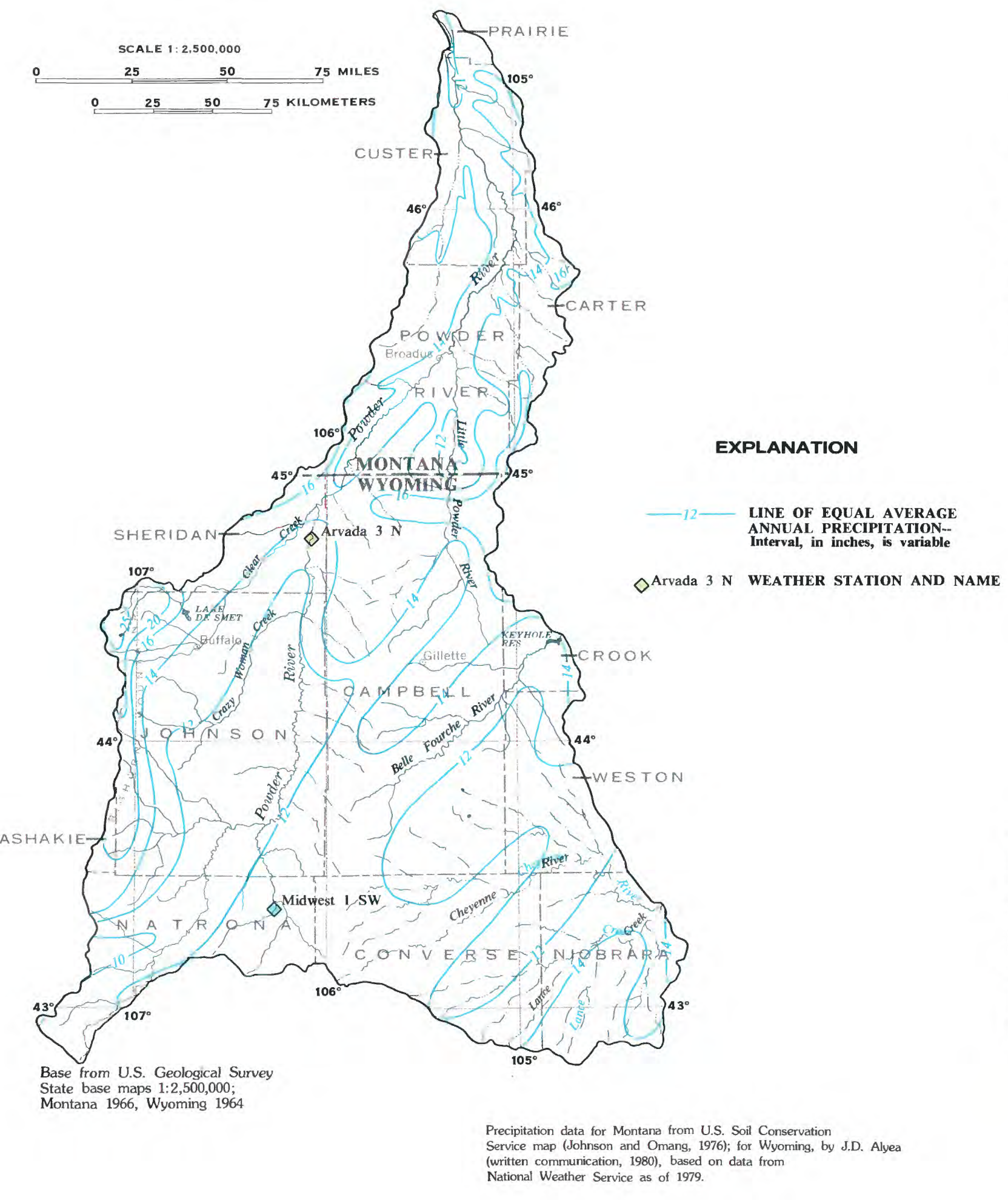

Figure 3.1-1 Average annual precipitation.
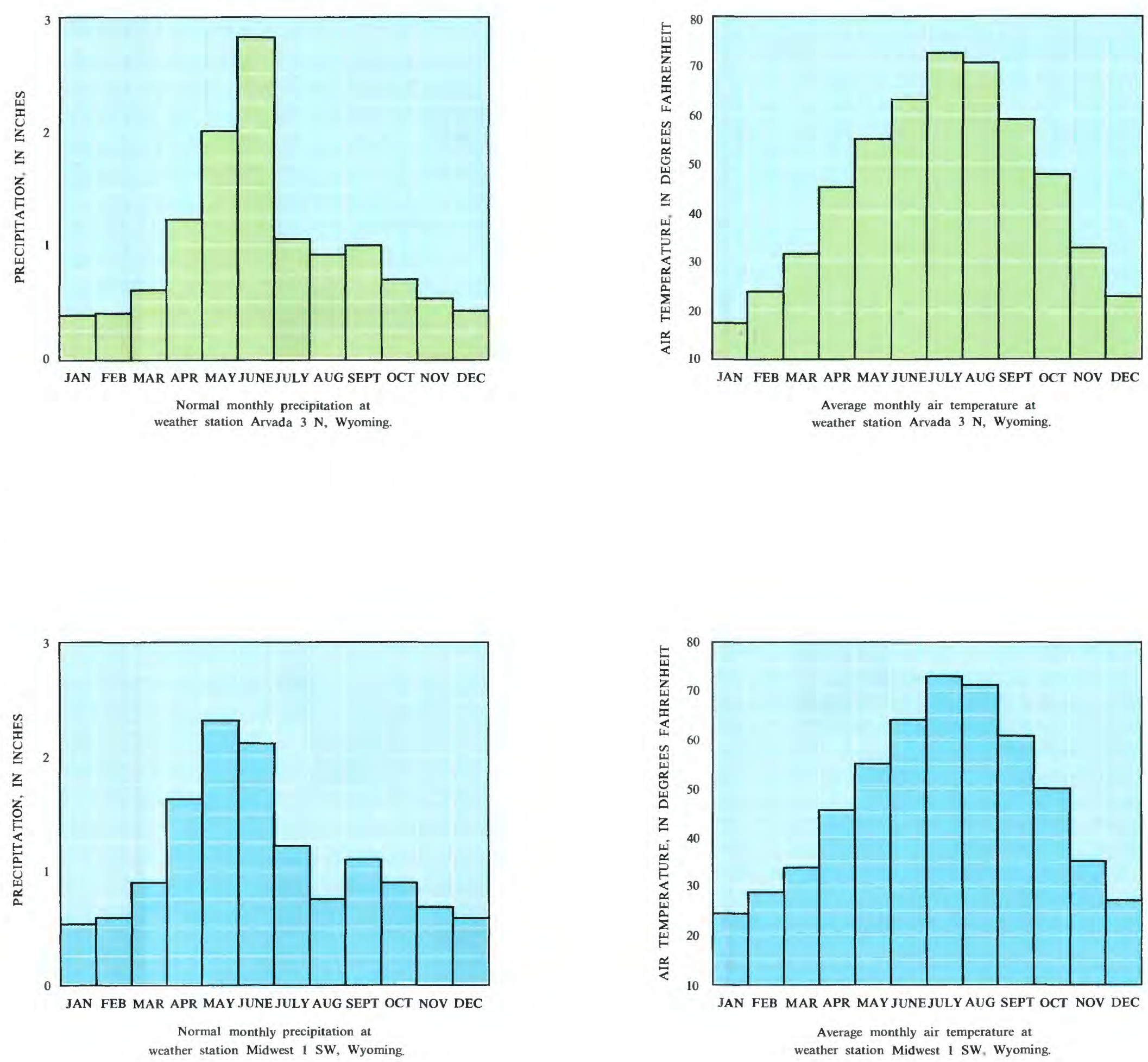

Figure 3.1-2 Monthly precipitation and air temperature based on records for 1941-70, from National Oceanic and Atmospheric Administration (1973). 


\subsection{PHYSIOGRAPHY--Continued}

3.2 Landforms

\section{Plains, Tablelands, and Open (Treeless) High Hills Predominate}

\section{The terrain of Area 50 varies from forested mountains to sand dunes, with most of the strippable coal deposits located in the semiarid plains and tablelands near the center of the area.}

Viewing Area 50 from a vantage point at Gillette, Wyo., near the center of the area, one would see the varied terrain and colors resulting from a semiarid climate (figure 3.2.1). To the southeast from Gillette are plains, rolling hills, and tablelands as far as the eye can see. Rivers and streams dissect the area. A dense carpet of grass covers the landscape, green in the spring and golden brown in the summer. Cattle, sheep, buffalo, and antelope graze on the land.

The view to the west and northwest includes the Powder River breaks, where the river has eroded deeply into the plains. Farther south, in the area of South Fork Powder River and Salt Creek, there are large areas where shales have been dissected into badlands. A few sand dunes can be seen along the southern edge of the area.
The lofty, snow-covered Bighorn Mountains, with peaks rising to 12,000 feet, rim the western edge of the area. Pine-forested mountainsides and valleys drained by cascading streams are the principal source areas of surface water for Area 50.

To the north in Wyoming and southern Montana are open high hills, with pine-forested escarpments along the Powder and Little Powder Rivers. Numerous red clinker-topped buttes accent the area. Majestic cottonwood trees with yellow-green leaves line the river valleys. In spring, green grasses cover the area, except for the scenic badlands along the eastern side of the Powder River in Montana, which remain bare. 


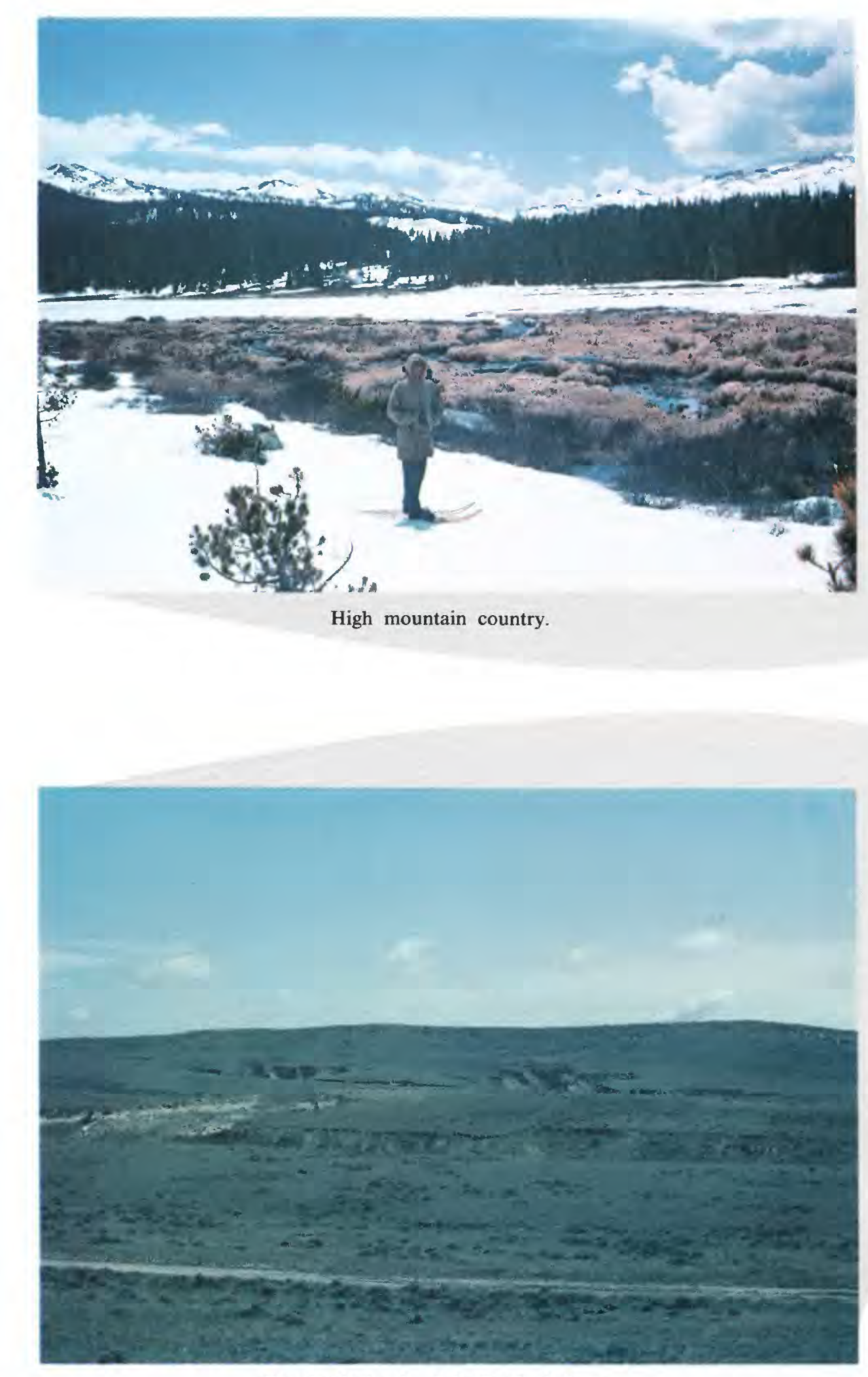

Grasslands in the Salt Creek drainage.

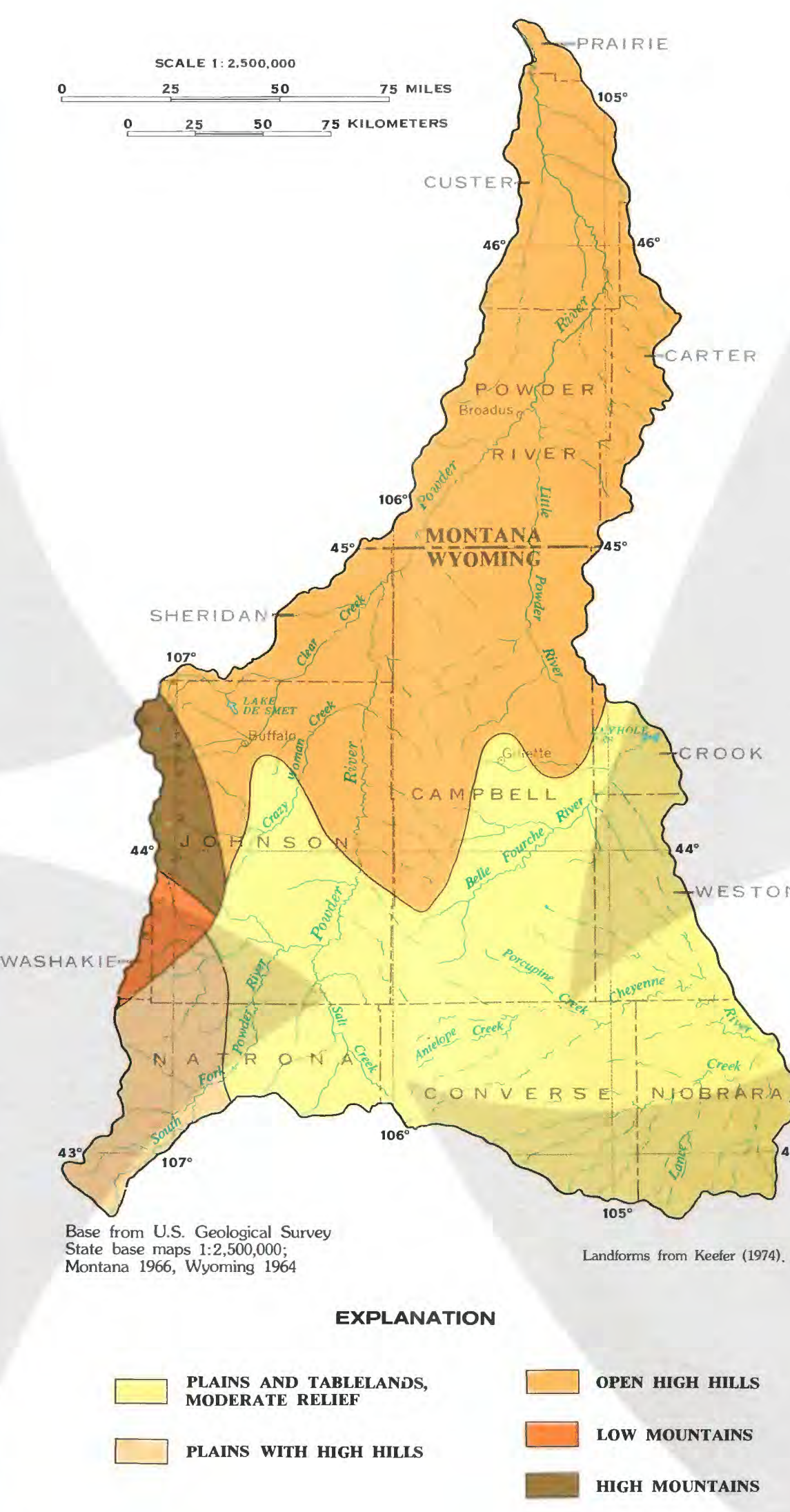

Figure 3.2-1 Distribution of landforms.

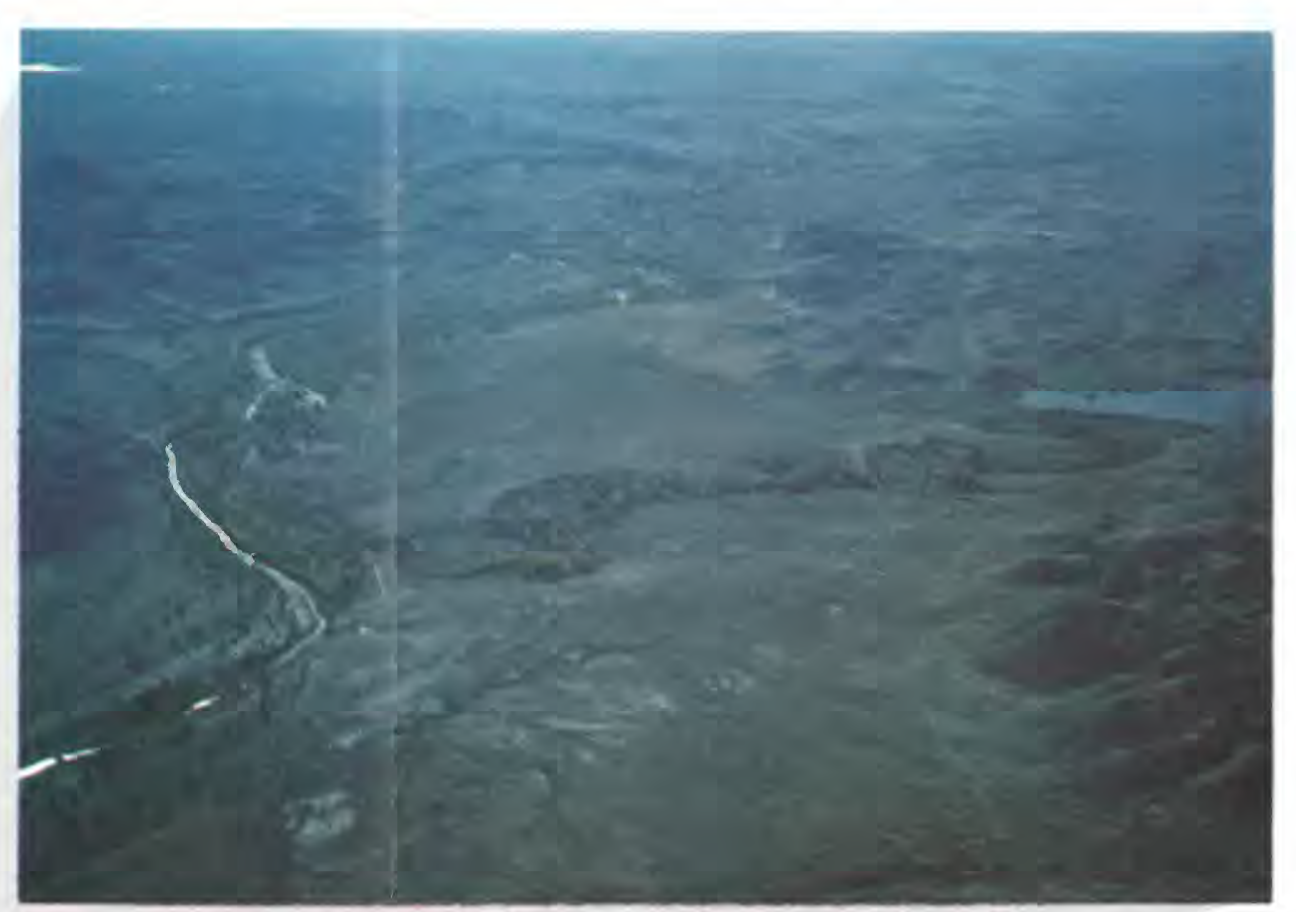

Antelope Creek at mouth of Porcupine Creek.

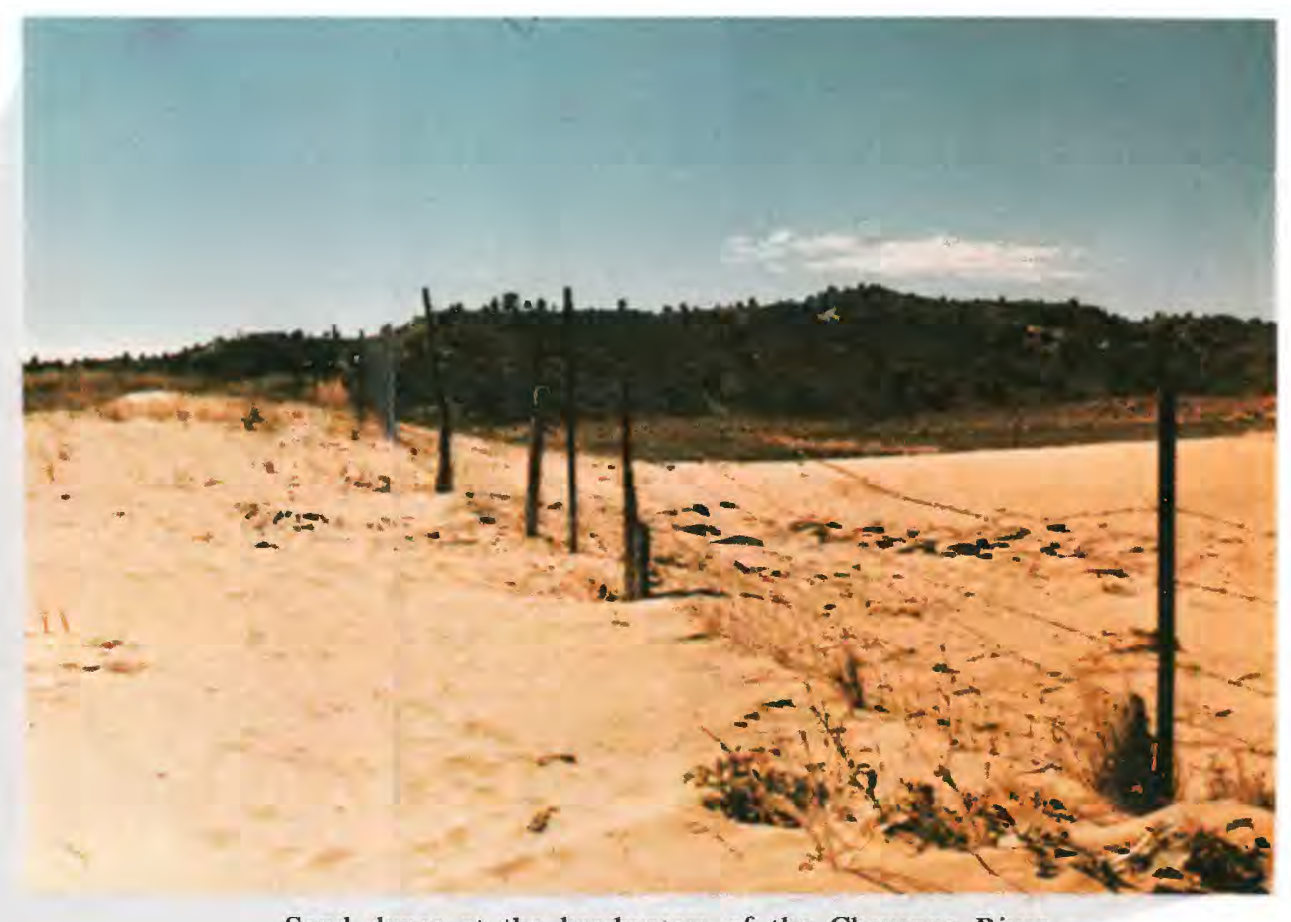

Sand dunes at the headwaters of the Cheyenne River. 


\title{
3.0 PHYSIOGRAPHY-Continued
}

\author{
3.3 Drainage
}

\section{Ephemeral and Interrupted Streams Drain Most of the Area}

\section{Ephemeral and interrupted streams drain 80 percent of the area and yield 40 percent of the runoff.}

The Cheyenne River and Lance Creek, ephemeral streams with interrupted reaches, originate near the center of the area. Most of the drainage of the two streams is underlain by continental deposits of shale, sandstone, and coal. The two streams and their major tributaries have wide, sand channels that are bordered by three terraces (fig. 3.3-1): the Lightning terrace at about 6 feet, the Moorcroft terrace at about 14 feet, and the Kaycee terrace at about 33 feet above the channel (Leopold and Miller, 1954). Streamflow primarily is from rainstorms and melting snow, with little contribution from ground water; however, the stream channels intercept the groundwater table in several reaches. Annual runoff is about 8.5 acre-feet per square mile.

The Belle Fourche River originates in and drains an area underlain by continental deposits of shale, sandstone, and coal. The channel is relatively narrow, has a silt and clay bottom, and in places is grass-covered (fig. 3.3-1). The alluvial terraces are much lower than those found in the Cheyenne River drainage. The Moorcroft terrace is missing in the upstream part of the drainage basin (Leopold and Miller, 1954). Streamflow is primarily from thunderstorms and snowmelt. The ground-water table is intercepted by the channel in many reaches, thus forming pools, but very little ground water is contributed to the streamflow. Most of the ground water evaporates from the pools. Annual runoff is about 10 acre-feet per square mile.
Channel-bottom material of the Little Powder River consists of clay, silt, and some clinker gravel. The stream flows northward through an alluvial valley $1 \frac{1}{2}$ miles wide, bordered by high escarpments. The stream is perennial and has an average annual runoff of about 15 acre-feet per square mile.

Clear Creek, Crazy Woman Creek, and the upstream reaches of the Powder River, which originate in the Bighorn Mountains, are perennial. These streams drain granitic and limestone areas. Precipitation in the mountains is about twice that in the plains. Annual runoff in many of the areas of the mountains exceeds 200 acre-feet per square mile.

Although the Powder River from Sussex, Wyo., to the mouth flows through a semiarid area, it is a perennial stream. Runoff for this reach includes sustained flow from the headwater areas in the mountains and direct runoff from rainstorms and snowmelt in the remainder of the drainage basin. The river has a wide, sandy channel. Three terraces are present: the Lightning terrace at about 5 feet, the Moorcroft terrace at about 16 feet, and the Kaycee terrace at about 45 feet above the stream channel (Leopold and Miller, 1954). The three terraces exist at the gaging station at Moorhead, Mont. (see photograph in figure 3.3-1). 


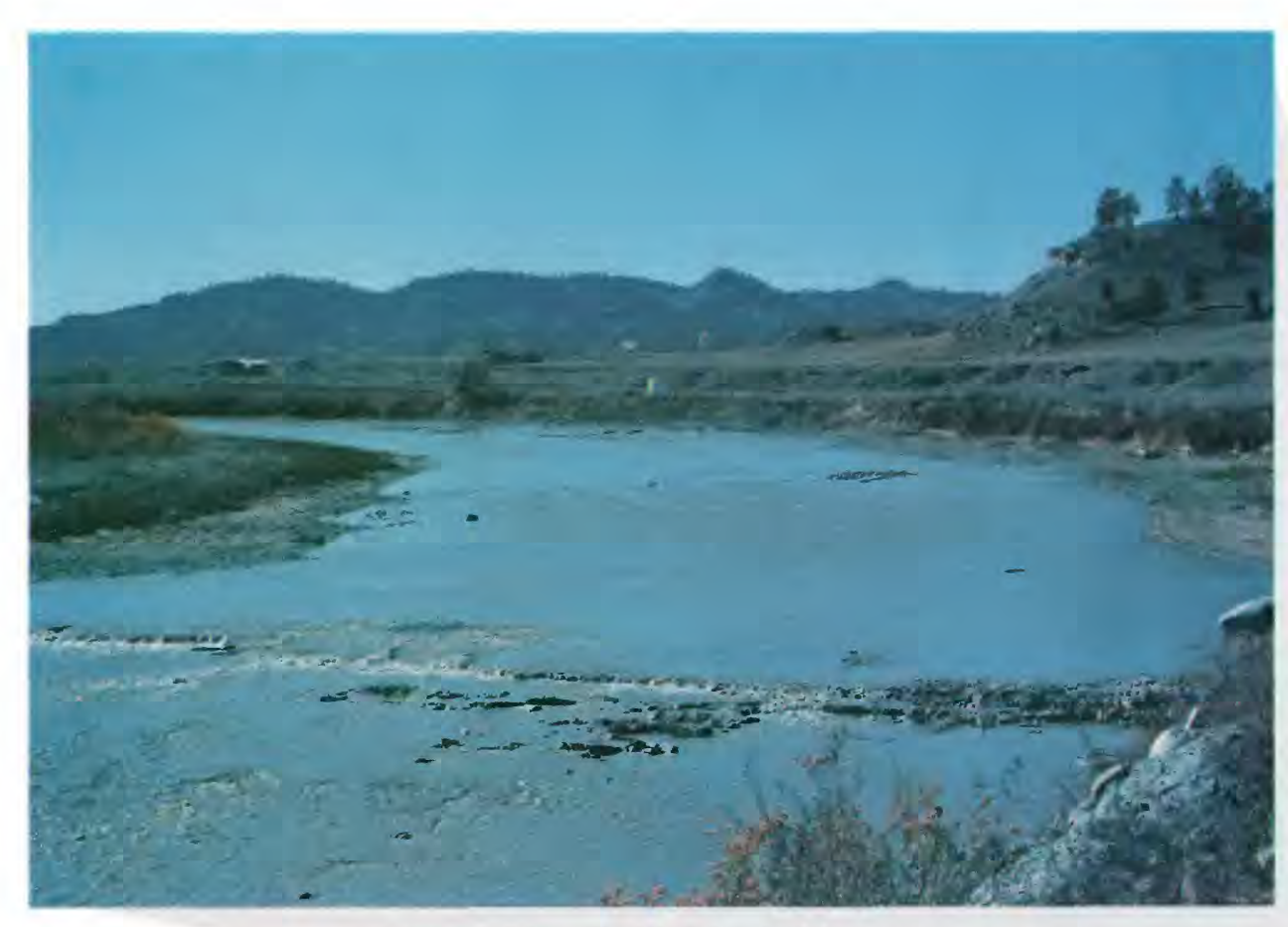

Powder River at Moorhead, Montana.

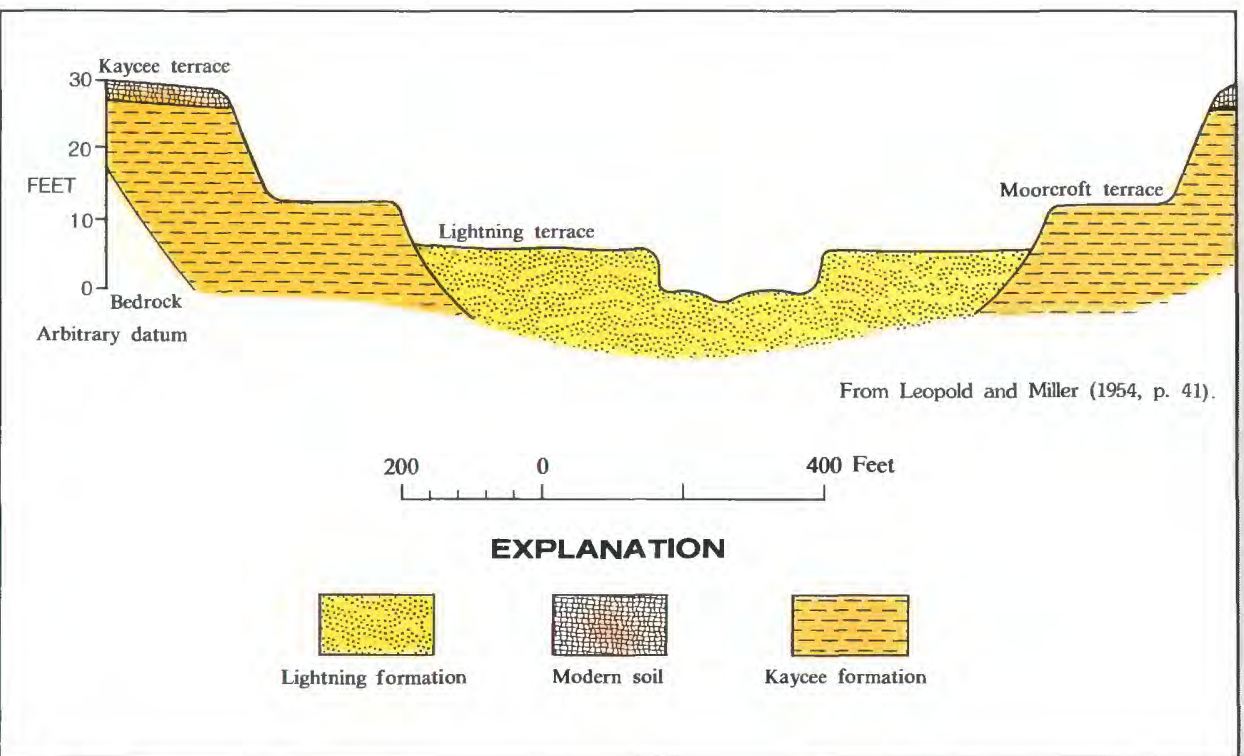

Cross section of a valley in the Cheyenne River Basin

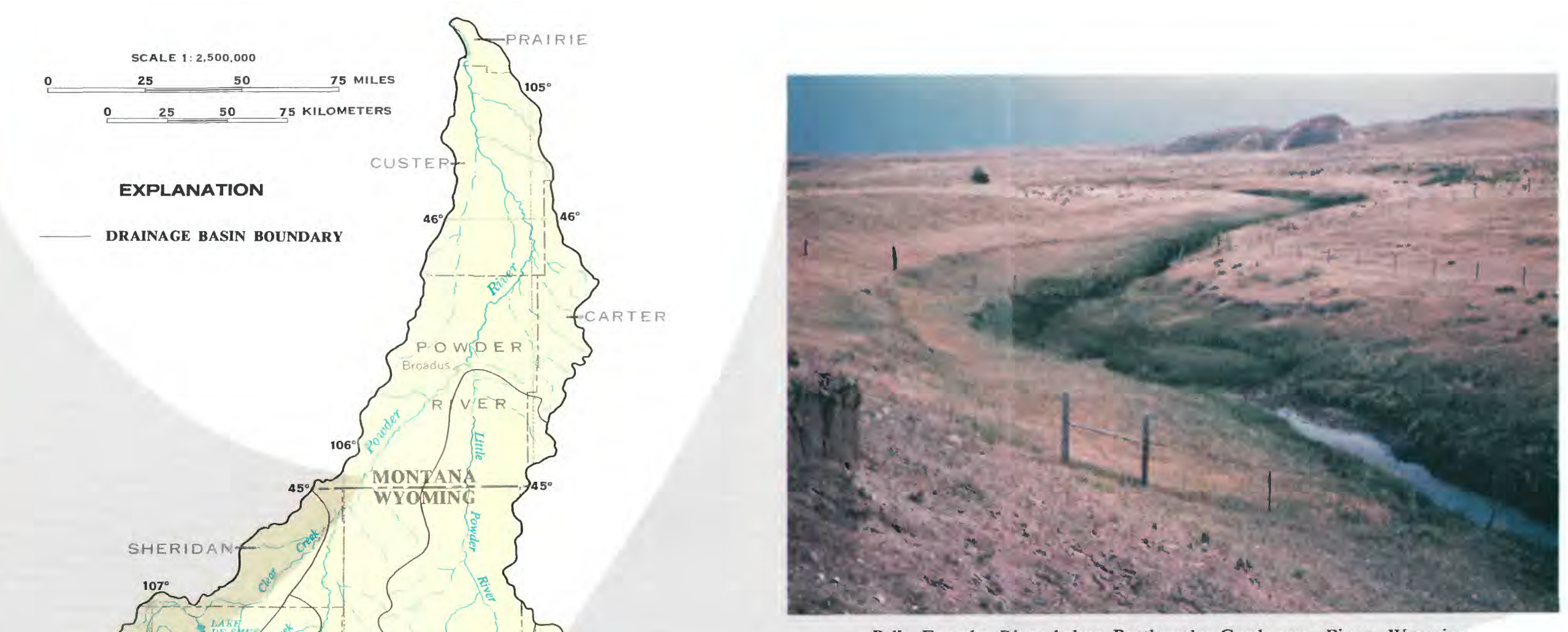

Belle Fourche River below Rattlesnake Creek near Piney, Wyoming

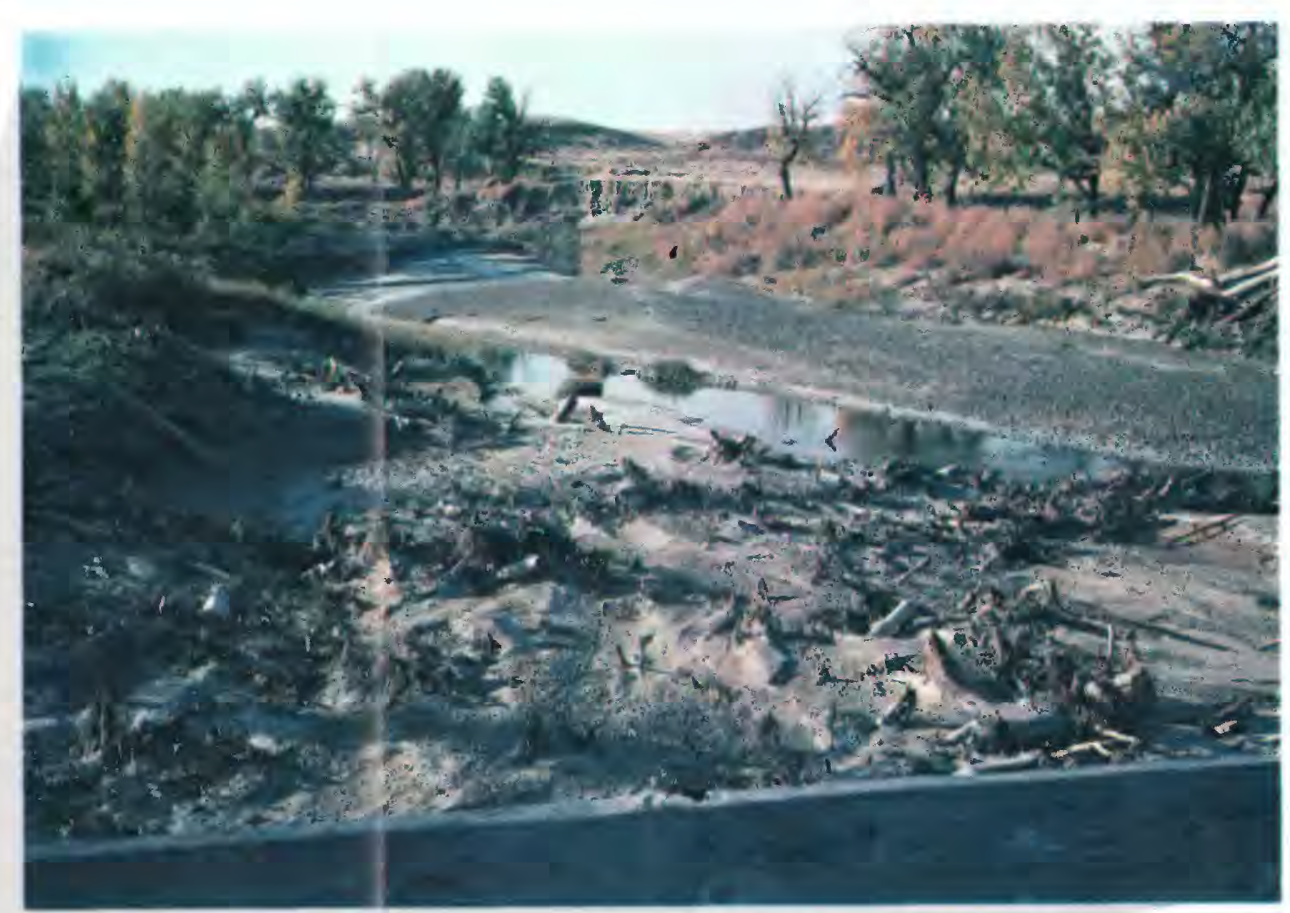

Figure 3.3-1 Drainage basins and terraces of principle streams.
Lance Creek near Bright, Wyoming. 


\title{
3.0 PHYSIOGRAPHY--Continued
}

3.4 Soils

\section{Soils of the Plains Cover 94 Percent of the Area}

\author{
Soils of the plains are classified by the land slope and the type of parent \\ material from which they are derived; soils of the mountains, which cover \\ 6 percent of the area, are unclassified.
}

Soils of the plains area generally contain little organic material, are fine grained, and are alkaline. The soils have a low-to-moderate permeability and a moderate-to-high potential for precipitation runoff. The sandy soils in the southern part of the area have a low potential for precipitation runoff. Most of the soils are moderately erodible by water. Sandy soils are not easily eroded by water but are easily eroded by wind.

Soils in mountain areas contain more organic material than the soils of the plains; they are coarser grained, and have less potential for precipitation runoff. These soils range from acidic to alkaline; the reaction depends on whether the parent material is acidic or basic. Soils of the mountains also have steeper slopes than soils of the plains.

The soils shown in figure 3.4-1 are classified by physiographic area, source of parent material, and land slope. Physiographic area is a broad classification group that separates soils of mountain areas from soils of plains areas. Soils of the plains are divided into those derived from transported material and those derived from residual material. These soils are further subdivided by land slope.
Climate, parent material, and slope affect the development of a soil. The mountain climate is characterized by cold winters, cool summers, generally more than 20 inches of precipitation, and 60 or fewer frost-free days. The plains climate is characterized by cold winters, warm summers, 12 to 18 inches of precipitation, and 110 to 140 frost-free days.

Silts and sands transported by floods and deposited on flood plains of streams are the primary source of transported material. Most of the soils in Area 50 are formed from residual materials. In the plains, these materials are derived from weathered flat-lying sandstone, siltstone, and shale. Most soils of the mountains are formed from residuum of igneous, metamorphic, and carbonate rocks.

Land slope affects runoff and erosion, which in turn affect the development and accumulation of soils. Land slopes have been divided into six classes. There are single slopes and complex slopes in each class, and each type of slope has its own descriptor. The slopes in Area 50 range from level ( 0 to 3 percent) to very steep (45 to 90 percent). 


\section{EXPLANATION}

SOIL TYPES

SOILS OF THE MOUNTAINS

Cryoborolls-Cryoborals

Cryoborolls-Rock Outcrop

SOILS OF THE PLAINS

Transported Material

tevel to genty sloping

Camborthids-Torrifluvents-Torriorthent

Torrifluvents-Haplargids-Torriorthen

Rolling to hummock,

Ustipsamments association

\section{steep slopes}

Calciborolls-Calciorthids

Residual Material

$\square$ Nearly level to rolling

Camborthids-Torriorthents (shallow)

Camborthids-Torriorthents

Haplargids-Camborthids-Natrargid

Haplargids-Paleargids-Torriorthen

Haplargids-Torriorthents

Torriorthents-Haplargids-Camborthids

Strongly sloping

Torriorthents (shallow)

Torriorthents-Camborthids

Torriorthents (shallow)-Camborthids-Torriorthen

Torriorthents (shallow)-Torriorthents-Camborthids

Torriorthents-Natrargids

Torriorthents-Haplargids

Torriorhents-Torriorthents (shallow

Torroorhents-Torriorthents, shallow Rock Outcrop

Torriorthents

Steep and very steep slopes

Badland-Torriorthents

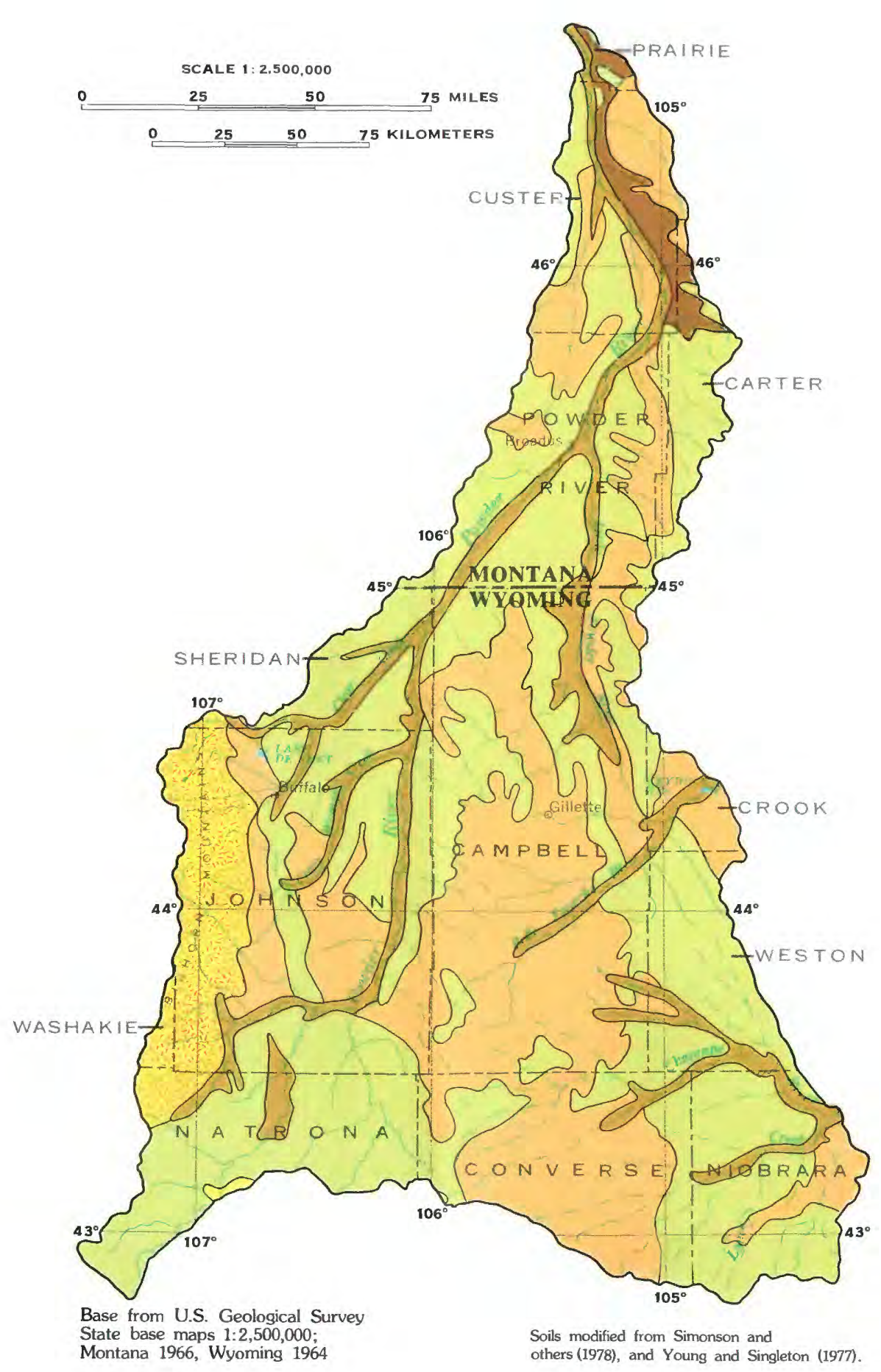

Figure 3.4-1 Distribution of soil types.
Table 3.4-1 Description of soil groups and land types.

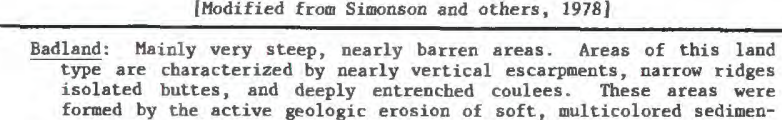

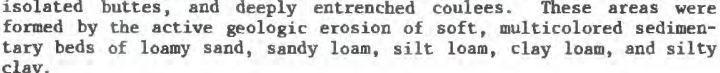

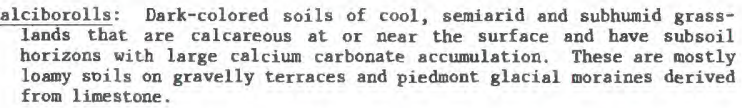

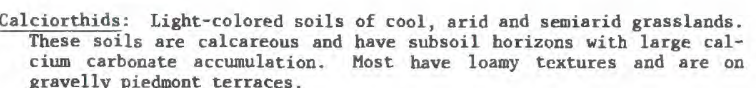

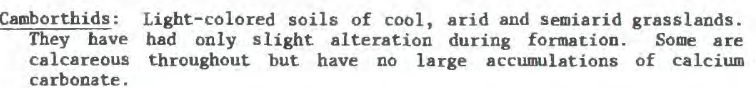

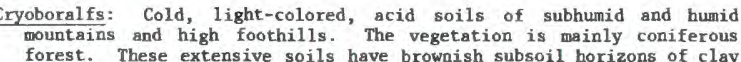

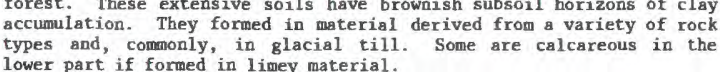

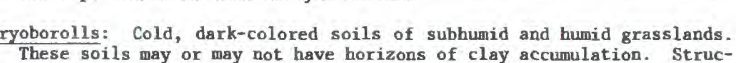

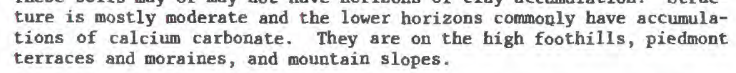

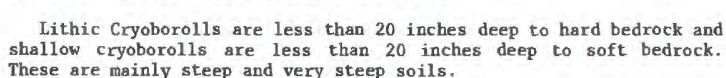

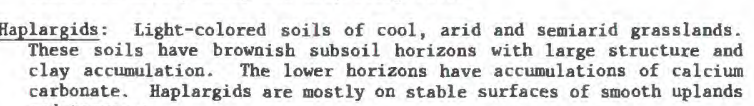

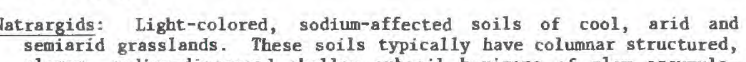

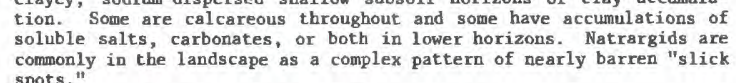

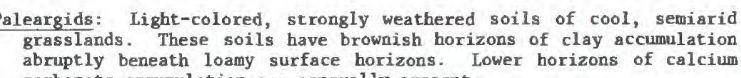

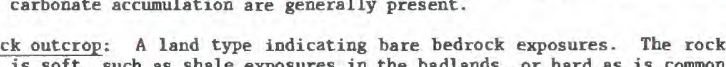

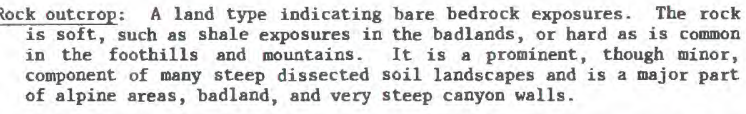

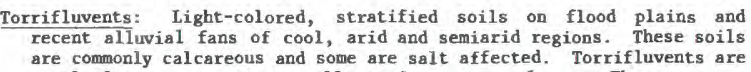

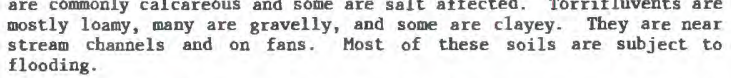

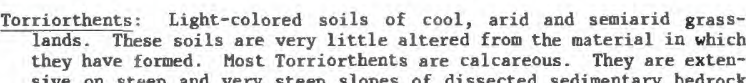
sive on steep and very steep stopes of dissected sedieetary bedrock
plains.

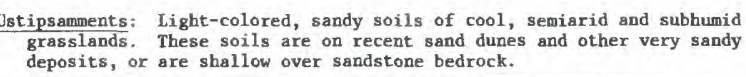




\title{
3.0 PHYSIOGRAPHY--Continued
}

\subsection{Vegetation}

\section{Grasses and Sagebrush are the Predominant Vegetation}

\author{
The plains support a mixture of grasses and sagebrush, whereas the \\ mountains and breaks support trees, grasses, and sagebrush.
}

The natural vegetation of most of Area 50 is a mixture of grasses and sagebrush. A map of vegetation types is shown in figure 3.5-1.

Common plants of the plains grasslands include prairie sandreed grass, needleandthread grass, western wheatgrass, blue grama grass, little bluestem grass, big sagebrush, and greasewood. Cottonwood trees commonly grow along stream bottoms in the plains, whereas breaks and upland areas may support thin stands of ponderosa pine and juniper. Examples of plains grassland are shown in figure 3.5-2.

Although vegetation appears to be sparse in the plains, the extensive root systems compete for the available moisture. Annual forage requirements for grazing land are estimated to be about 30 to 60 acres per cow.

The vegetation of the western edge of Area 50 reflects greater precipitation on the mountains than on the plains. Trees, such as Douglas fir, alpine fir, and aspen, are the predominant vegetation in the mountains; pines predominate in the foothills. Bluebunch wheatgrass, columbia needlegrass, spike fescue, and big sagebrush are common plants in the clearings between the trees. 


\section{EXPLANATION}

VEGETATION TYPE

$\square$ FOREST (mountains)

FOREST (foothills)

GRASSLAND (southern plains)

GRASSLAND (northern plains)

GRASSLAND (northern plains with trees
on breaks and upland areas)

GRASSLAND (arid basins)

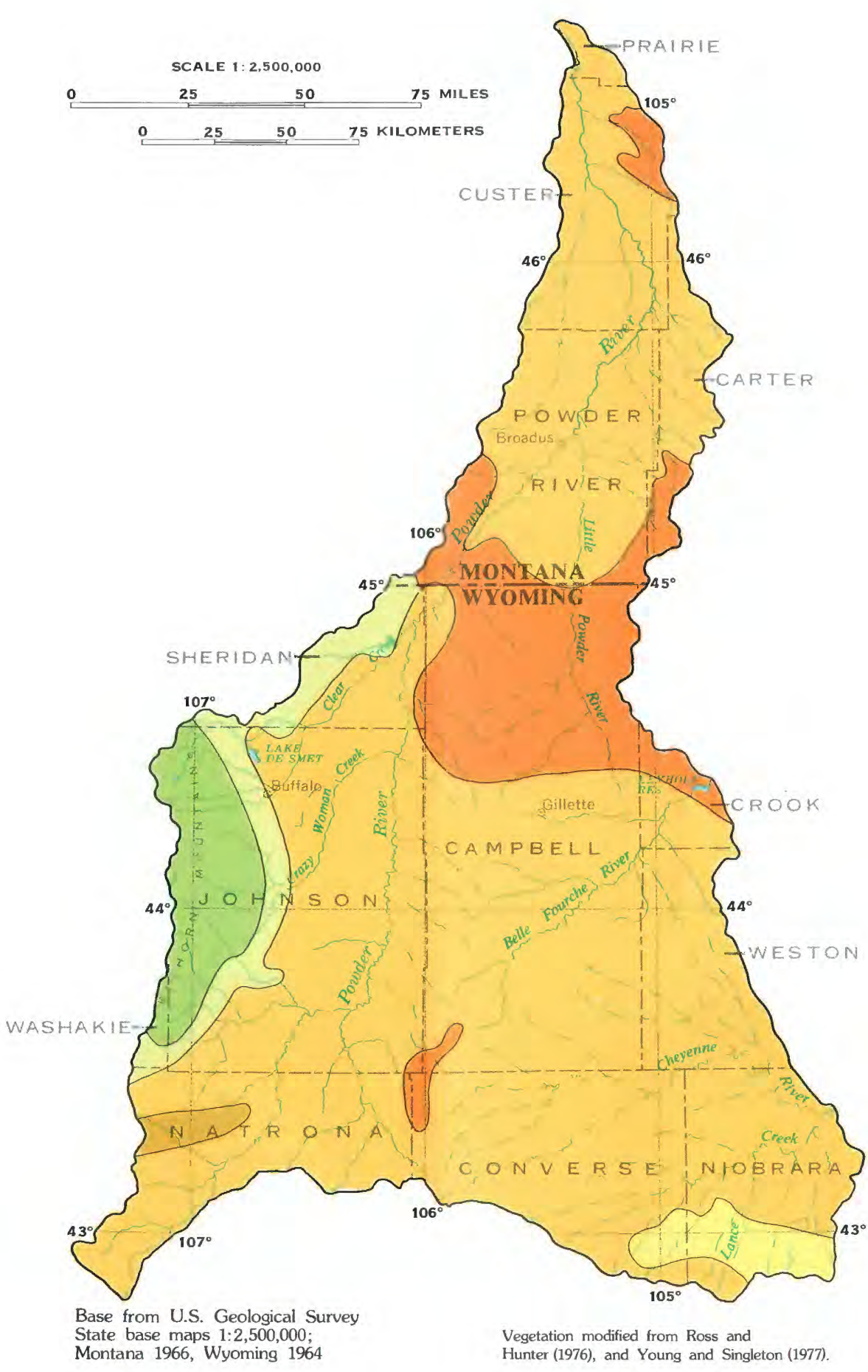

Figure 3.5-1 Distribution of vegetation types.
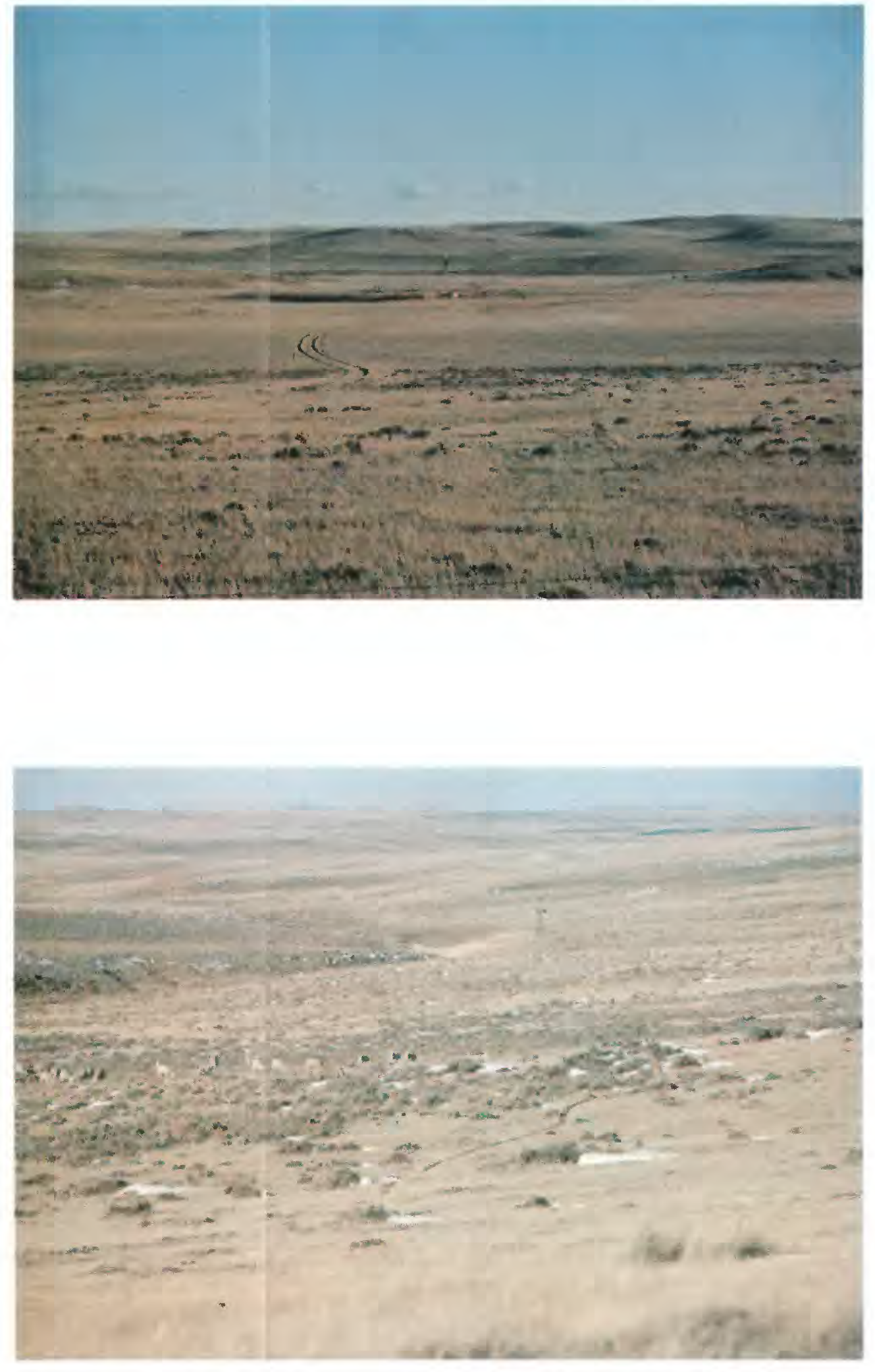

Figure 3.5-2 Examples of northern plains grassland.

3.0 PHYSIOGRAPHY--Continued 3.5 Vegetation 


\subsection{PHYSIOGRAPHY--Continued \\ 3.6 Geology \\ 3.6.1 Structure and Stratigraphy}

\section{Much of the Coal is Nearly Flat-Lying}

\section{Rocks representing all geologic periods are present; coal was deposited during the Cretaceous and Tertiary Periods.}

Area 50 is located principally within the Powder River structural basin, but part of the area is in the Wind River basin, which is separated from the Powder River Basin by the Casper arch. The Casper arch also separates the Rocky Mountain Coal Province from the Northern Great Plains Coal Province. Parts of the area extend into the Bighorn Mountains and the Sweetwater and Hartville uplifts (fig. 3.6.1-1).

Few major faults are present in the central part of the Powder River basin, where most economic coal deposits are located; hence the coal beds are not greatly disrupted by faulting. On the east side of the basin, dips are slight (fig. 3.6.1-2) and the coal is nearly flat-lying.

The oldest rocks are igneous and metamorphic rocks of Precambrian age. Next oldest are the lower Paleozoic rocks--marine sandstone, carbonates, and shale; carbonates such as the Madison Limestone are the predominant rock type (fig. 3.6.1-3). The upper Paleozoic rocks are more complex and include thick sandstone overlain by red shale intertongued with limestone; evaporites also are present. Deposition of red shale intertongued with limestone and evaporites continued during the early part of the Mesozoic, subsequently being replaced by alternating and intertonguing marine and continental deposition.

During Early Cretaceous time, a thick sequence of marine shale was deposited over most of the area. The shale is interfingered with marine sandstone and some continental deposits in the western part of the area. Some limestone was deposited in the eastern part of the the area. The oldest coal in the area is in these rocks.

During Late Cretaceous time, the sea withdrew from the area, depositing the Fox Hills Sandstone, and deposition of continental shale, sandstone, and coal in a tropical, near-sea-level environment began. This deposition continued through early Tertiary time, when the present basin shape was established and the mountains had risen high above the surrounding terrain.

Later during the Tertiary Period there was regional uplift, and arid conditions prevailed (Van Houten, 1964, p. 79). Basin filling continued until only the highest mountain peaks were above the general land surface. The deposits were partly sand, siltstone, and near the mountains, some boulder conglomerates. Some of the clastics were derived from volcanics. Igneous rocks were intruded in the extreme southwest part of the area at this time. Subsequent erosion has removed most of the upper Tertiary rocks from the area, leaving only remnants such as Pumpkin Buttes in southwestern Campbell County, Wyo.

Continental ice sheets did not extend into the area. Alpine glacial deposits, however, are present in the highest parts of the Bighorn Mountains. Although many streams flow on bedrock, alluvium is present, even in minor drainages. The general finegrained character of the alluvium has been described by Leopold and others $(1964$, p. 438). 

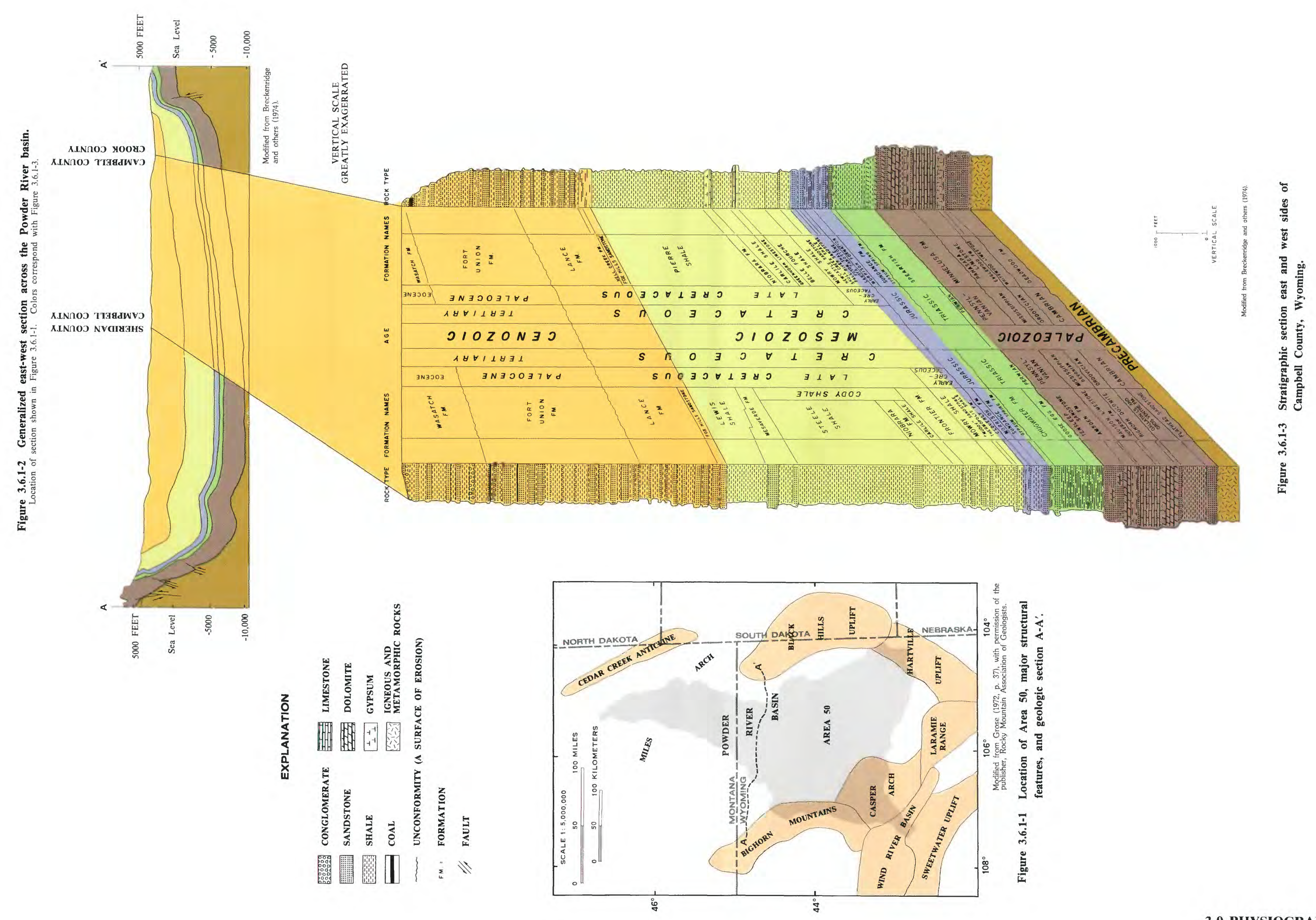


\subsection{PHYSIOGRAPHY--Continued \\ 3.6 Geology-Continued \\ 3.6.2 Surficial Geology}

\section{Distribution of Surficial Rocks Reflects Geologic Structure}

\section{Surficial geology is similar to that which preceded deposition of Oligocene rocks.}

The predominant surficial rocks in Area 50 are those of the coal-bearing sequence, which are exposed throughout most of the Powder and Wind River basins. Differential uplift and erosion, however, have resulted in exposure of older rocks along the margin of Area 50. The principal geologic structures are numbered in figure 3.6.2-1 and the same number is shown at the corresponding location in the map of the surficial geology (fig. 3.6.2-2)
The present surficial geology is similar to that which was present before the deposition of the Upper Tertiary continental deposits. These deposits subsequently have been nearly all removed by erosion and are present as erosional remnants only in and near the Bighorn Mountains, at Pumpkin Buttes, and in the southeastern part of the area.

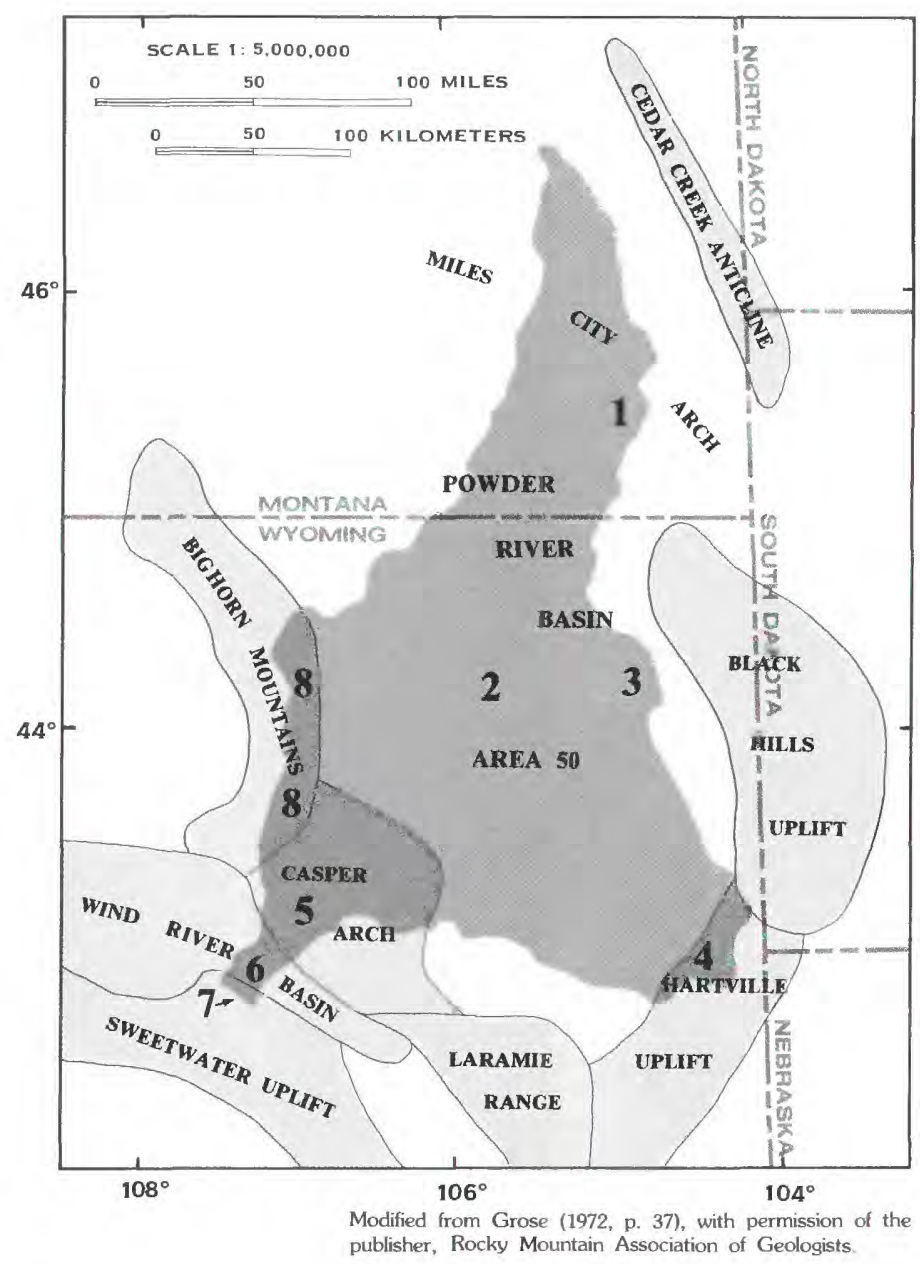

Figure 3.6.2-1 Structural features in and near Area 50. Location of numbers correspond to the same number on Figure 3.6.2-2. 


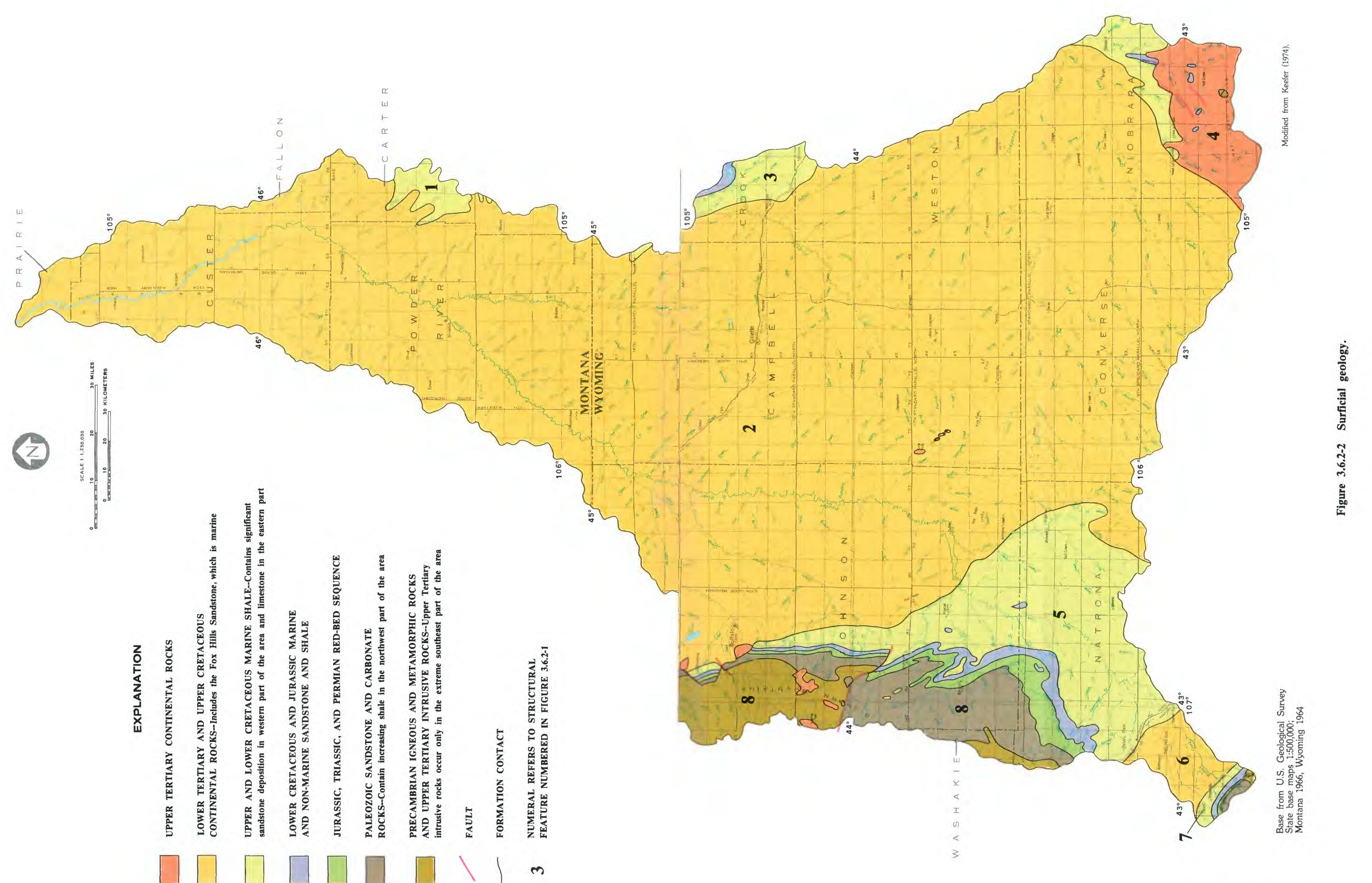




\title{
3.0 PHYSIOGRAPHY--Continued \\ 3.6 Geology--Continued \\ 3.6.3 Coal
}

\section{Extensive Coal Deposits Are in the Area}

\author{
Most coal beds are within the Fort Union and Wasatch Formations; the average \\ thickness of the only coal bed mined during 1983 was 70 feet.
}

The coal deposits in Area 50 are within three major coal-bearing areas: The Powder River Coal Basin, the Fort Union Coal Region, and the Wind River Coal Basin (fig. 3.6.3-1). Most of Area 50 is within the Wyoming part of the Powder River Coal Basin, but the northward extension of the area, into Montana, is almost entirely in the Fort Union Coal Region. Both the Powder River Coal Basin and the Fort Union Coal Region are part of the Northern Great Plains Coal Province. Only the small coal-bearing area in the extreme southwestern corner of Area 50 is part of the Wind River Coal Basin, which is in the Rocky Mountain Coal Province.

In the early 1900's, these three major coal-bearing areas were divided into numerous coal fields. More recent studies by the U.S. Geological Survey, the Montana Bureau of Mines and Geology, and The Geological Survey of Wyoming have identified the coal geology in detail. Glass $(1976,1980 \mathrm{~b}, 1982)$ summarizes the coal geology of northeastern Wyoming, which includes Area 50, and provides lists of references; Cole and others $(1980,1982)$ and Matson and Blumer (1973) provide similar summaries for Montana as well as lists of pertinent references.

Coals are reported in the Upper Cretaceous Mesaverde and Lance (Hell Creek) Formations in the southern part of Area 50. However, the thickest and most important coal beds are in the Paleocene Fort Union Formation and the overlying Eocene Wasatch Formation (fig. 3.6.1-3). Within the Fort Union Formation, which is 2,000 to 3,000 feet thick, the most persistent and thickest coal beds are in the 1,500- to 1,800-foot-thick upper member, the Tongue River Member. Tongue River Member coal beds are best developed in the central and eastern parts of Area 50, where they have an almost imperceptible westward dip of 2 to 3 degrees.

Of the seven to nine major minable coals reported in the Tongue River Member in Area 50 (fig. 3.6.3-2), only the Wyodak coal bed is mined; in fact, this is the only coal bed mined in Area 50. The outcrop of the Wyodak coal bed, though naturally burned in many places, has been mapped for more than $\mathbf{1 0 0}$ miles along the eastern side of Area 50. Coals equivalent to the Wyodak also are tentatively correlated into the Sheridan, Wyo. area, 80 miles west of Gillette (fig. 3.6.3-2).

The subbituminous Wyodak coal bed is 25 to 175 feet thick, and probably averages 70 feet in thickness. The coal has variously been called the Wyodak-Anderson and Anderson-Canyon coal bed. Because of correlation problems, the Wyodak coal bed was erroneously called the RolandSmith coal bed in the older reports.

To the west of Gillette, the Wyodak coal bed separates into the Anderson and Canyon coal beds, with the two beds each 10 to 65 feet thick (fig. 3.6.3-2). North from Gillette, the Wyodak separates into an Upper Wyodak and Lower Wyodak. In places, the Upper Wyodak separates into the Smith, Swartz, and Anderson coal beds and the Lower Wyodak separates into the Canyon and Cook coals (Kent and others, 1980). When the Wyodak separates into five or more beds, the individual coal beds are 3 to 38 feet thick and separated by a few feet to 200 feet of claystone, shale, or sandstone. The Wyodak also separates into the Anderson coal ( $\mathrm{D}$ bed) and the Canyon ( $\mathrm{E}$ bed) southward from Gillette (fig. 3.6.3-2).

The Eocene Wasatch Formation, which is 1,000 to 2,000 feet thick, is the second most important coal-bearing formation in the Powder River Coal Basin. The Wasatch Formation crops out in most of the western part of Area 50 and generally has dips of less than 3 degrees.

The Wasatch Formation contains as many as eight thick, persistent coal beds (fig. 3.6.3-2). The thickest Wasatch coal bed occurs at Lake DeSmet on the west side of Area 50. There, the Lake DeSmet coal bed locally exceeds 200 feet in thickness (Mapel, 1958; Obernyer, 1980). Wasatch coals have been mapped and correlated for tens of miles along outcrops in many areas but these coals are thicker and more persistent in the northwestern and central parts of Area 50.

Currently (1983) no Wasatch coals are mined in Area 50 , although some companies have recently proposed to mine Wasatch coals in the vicinity of Lake De Smet. Wasatch coals--the subbituminous School and Badger coal beds, however, are mined just south of Area 50 in Converse County, Wyo., and the mining will progress into the area.

With the exception of the Paleocene lignites in the Fort Union Coal Region, all the near-surface coals in Area 50 are reportedly of subbituminous rank, including the Cretaceous coals. It is possible, however, that the more deeply buried coals, and the Cretaceous coals in particular, may be bituminous at depth. A summary of the content and heat value of coal samples from the Wyodak, School, and Badger coal beds and the thickness of the coals is given in table 3.6.3-1. 


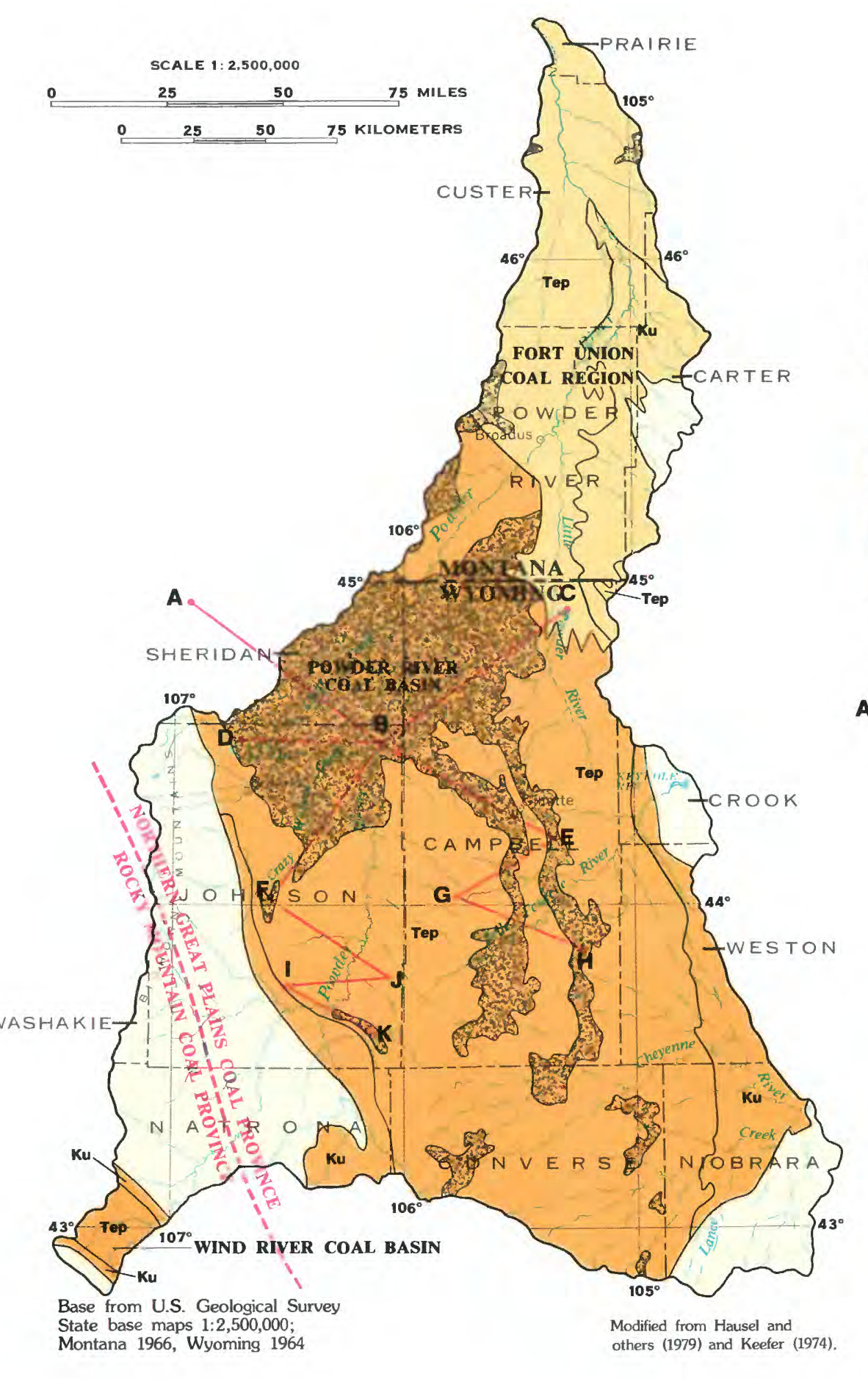

Figure 3.6.3-1 Coal-bearing parts of Area 50 and rank of coal.
EXPLANATION

Tep EOCENE AND PALEOCENE COAL-BEARING ROCKS

\begin{tabular}{|l|l}
\hline KU UPPER CRETACEOUS COAL-BEARING ROCKS \\
\hline
\end{tabular}

AREA HAVING IDENTIFIED,

A COAL RANK

Lignite

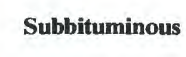

COAL BASIN BOUNDARY

CONTACT

A B bocation of cross SEction

Table 3.6.3-1 Characteristics of coals currently mined [s]acent to Area 50.

\begin{tabular}{|c|c|c|c|c|c|c|}
\hline 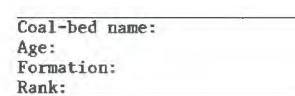 & $\begin{array}{c}\text { Wyode } \\
\text { Prale } \\
\text { Fort } \\
\text { Subbitum }\end{array}$ & & 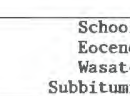 & & 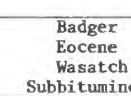 & \\
\hline & Range $^{2}$ & Average ${ }^{2}$ & Range $^{3}$ & Average 3 & Range 4 & Average ${ }^{4}$ \\
\hline Moisture (percent) ${ }^{1}$ & $21.1-36.9$ & 29.8 & $19.5-26.4$ & 22.2 & $22.7-29.3$ & 27.4 \\
\hline Volatile matter (percent) 1 & $26.5-35.5$ & 30.7 & $34.4-38.1$ & 35.9 & $31.7-34.5$ & 33.3 \\
\hline Fixed carbon (percent) ${ }^{1}$ & $29.6-41.4$ & 33.5 & 28.3-33.6 & 30.5 & 28.5-32.6 & 31.4 \\
\hline Ash (percent) ${ }^{1}$ & $3.9-12.2$ & 7.9 & $8.8-15.7$ & 11.4 & $6.6-9.8$ & 7.9 \\
\hline Sulfur (percent) ${ }^{1}$ & $0.2-1.2$ & .5 & $0.5-0.7$ & .6 & $0.4-0.5$ & .45 \\
\hline 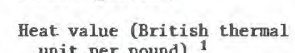 & $7,420-9,6000$ & 8,220 & $7,830-8,870$ & 8,180 & $7,610-8,290$ & 0 \\
\hline Thickness (feet) & 25-175 & 70 & 22-38 & 35 & $17-20$ & 18.5 \\
\hline
\end{tabular}
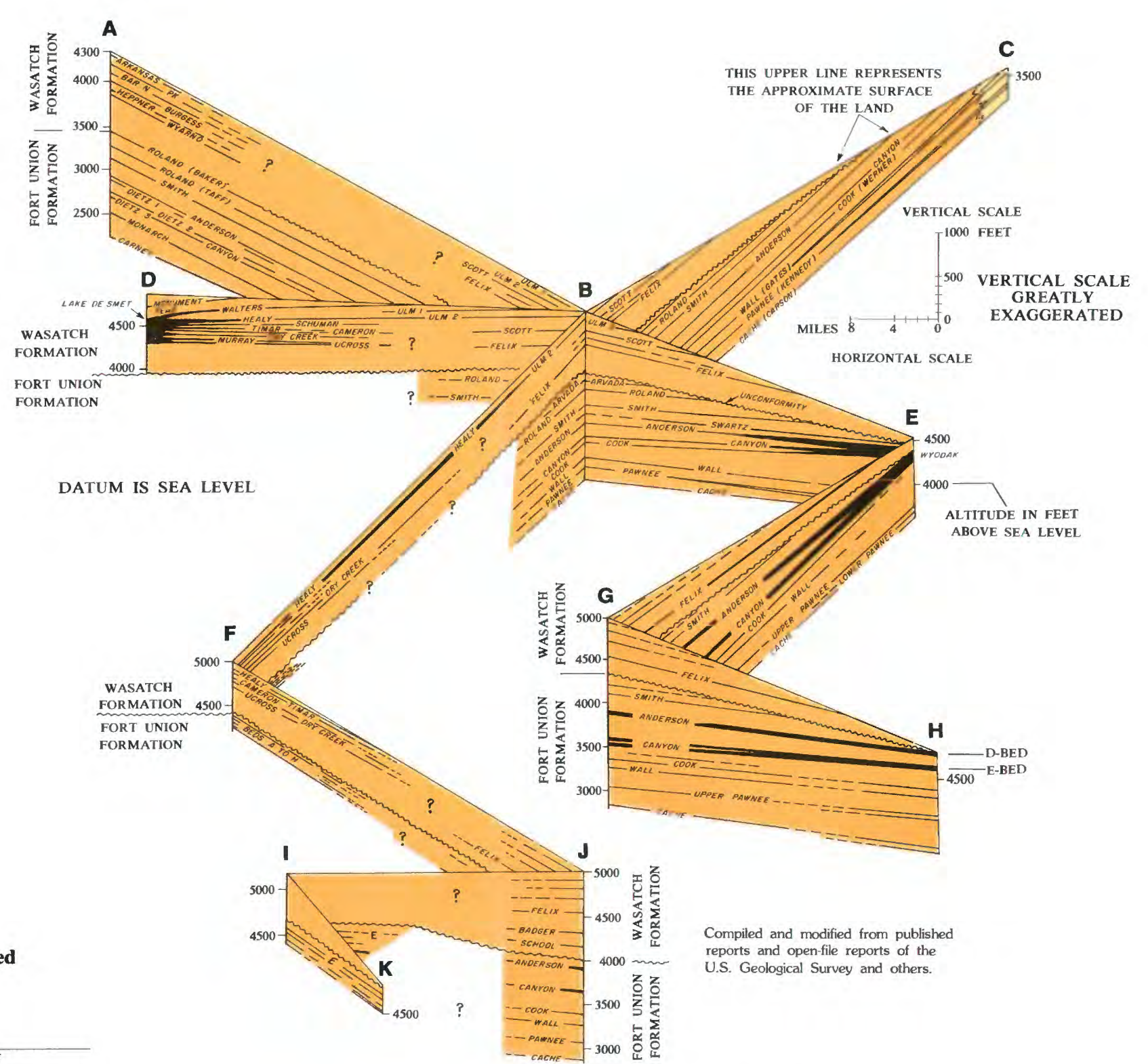

Figure 3.6.3-2 Correlation of principal coal beds. 


\title{
4.0 ECONOMIC DEVELOPMENT \\ 4.1 Surface Ownership
}

\section{Most of the Land Surface is Privately Owned}

\author{
State and Federal Governments own less than one-half the land surface.
}

Private and government land-surface ownership differs greatly from county to county within Area 50, as shown in figure 4.1-1. Approximately 80 percent of the land surface in Campbell County is privately owned (Wyoming Department of Administration and Fiscal Control, 1981); Campbell County is the center of active coal mining in Area 50. Of the privately owned land surface in Campbell County, individual ranchers own 60 percent, ranch companies and coal companies own 35 percent (Gary B. Glass, written commun., 1983). The government owners are primarily the States of Wyoming and Montana, and the Federal government.

Sections 16 and 36 of every township, called school sections, were granted to Montana and Wyoming upon admission to the Union. Revenues from these lands were to be used for education. This pattern of ownership, shown in figure 4.1-1, is different only where trades, purchases, or sales by have been made by the States.
Nearly all the land surface owned by the Federal government is under the jurisdiction of the U.S. Forest Service and the U.S. Bureau of Land Management. The Forest Service administers the Bighorn National Forest, the Thunder Basin National Grassland, and Bankhead-Jones land. The BankheadJones Act of 1937 and the Taylor Grazing Act of 1934 were enacted to promote sound land-use practices. The Taylor Grazing Act placed substantial areas of Federal land under the jurisdiction of an agency that is now the Bureau of Land Management.

The checkerboard pattern of Federal land ownership in the northern part of the area resulted from the Federal grant of the odd-numbered sections of land to the Northern Pacific Railroad. The grant was an incentive to build a northern transcontinental railway to benefit the settlement of the West. Landownership patterns in Wyoming are described in more detail by Calef (1960) and in the Rocky Mountain region by Foss (1960).

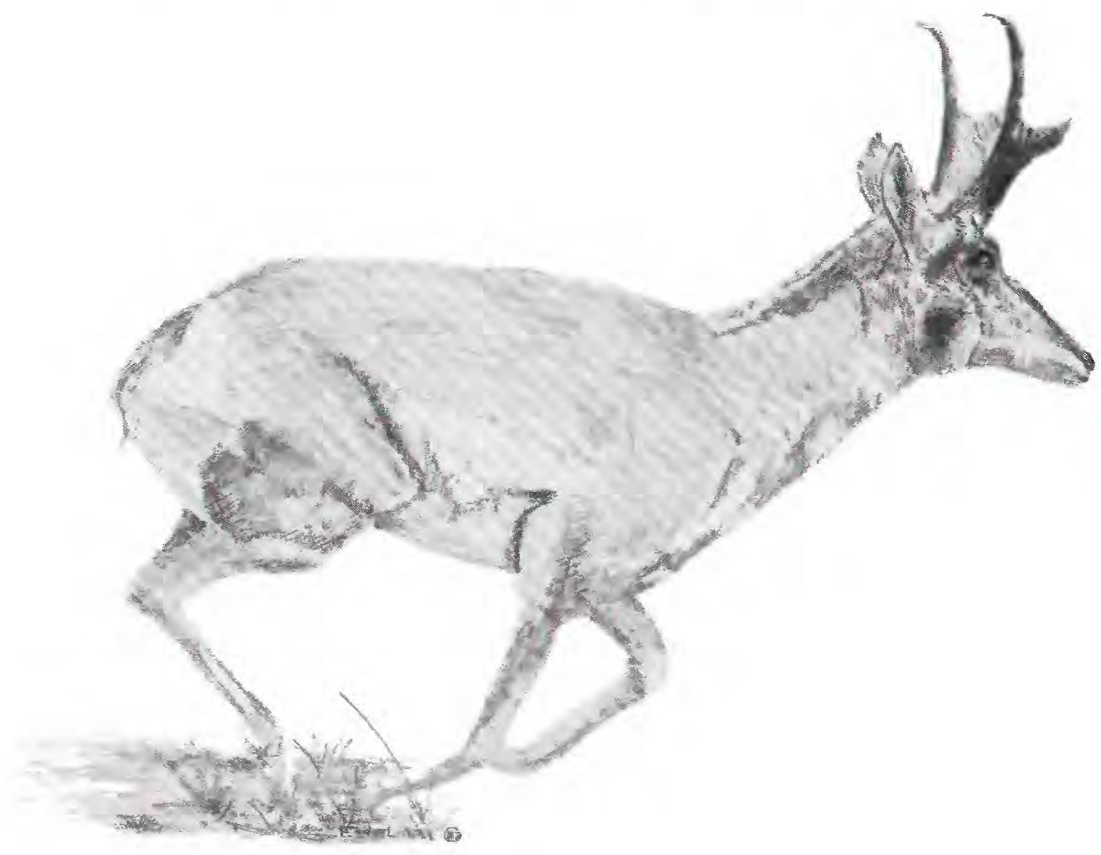




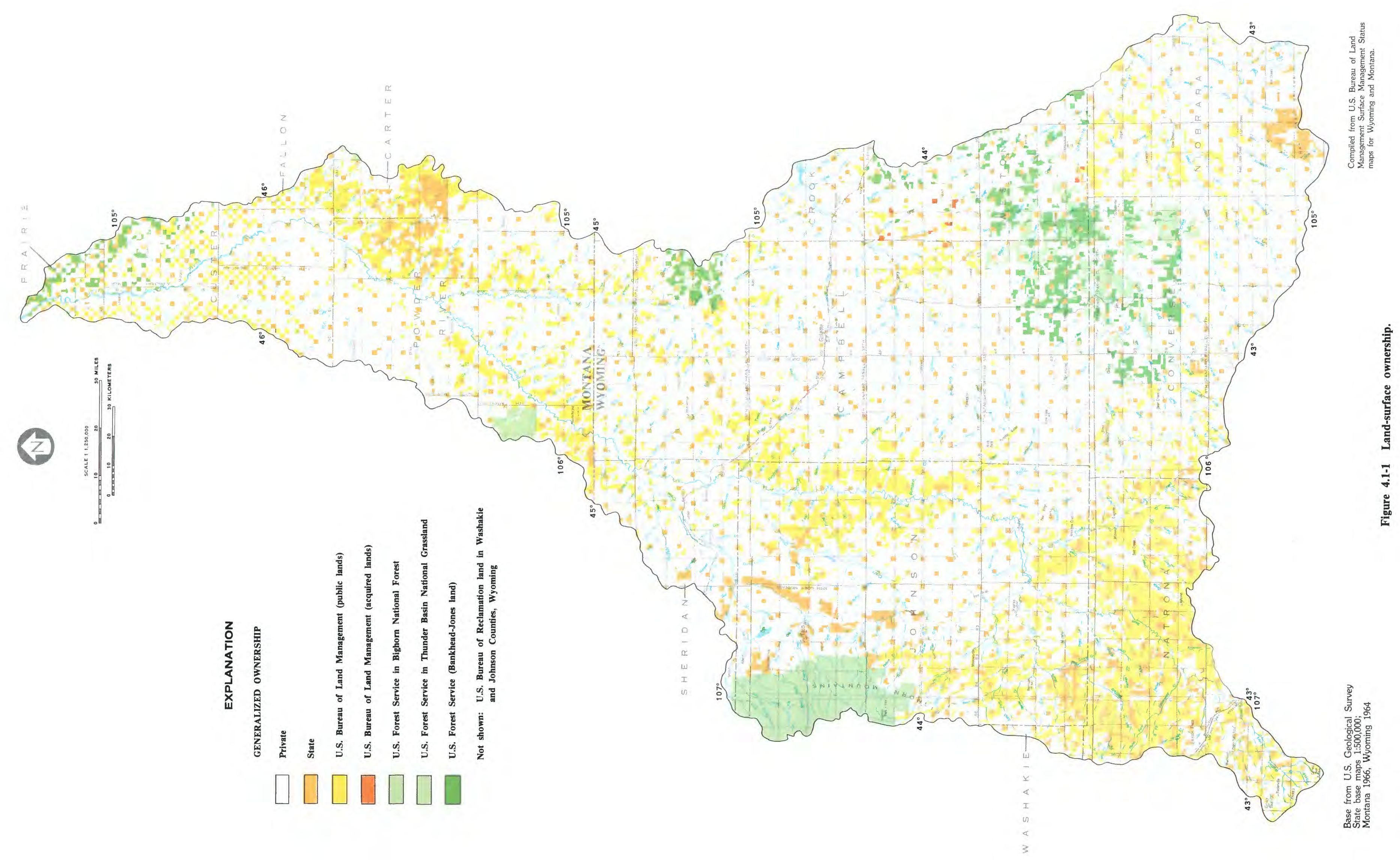




\title{
4.0 ECONOMIC DEVELOPMENT--Continued \\ 4.2 Minerals Ownership
}

\section{Federal Government Owns Most of the Coal}

\author{
Private ownership of minerals was granted with the earliest homesteads, most of \\ which are along major streams and near the mountains, and with land granted to \\ the State and to the railroads.
}

The pattern of mineral ownership of the States and the checkerboard pattern of land given to the railroads (fig. 4.2-1) is the same as that of surface ownership described in section 4.1 ; the mineral estate was included with surface ownership for the earliest homesteads. Subsequently, however, a difference between land-and mineral-ownership patterns began to develop, as mineral rights increasingly were reserved by the Federal government. Finally, the Homestead-Grazing Act of 1916 was passed, which reserved all mineral rights on homestead lands for the Federal government. The result of this change in homestead laws is indicated on the map by more private ownership of minerals on some of more desirable agricultural land, such as along major streams and near the mountains, in contrast to the rest of the area. The Surface Mining Control and Reclamation Act of 1977, however, includes special mining regulations for protection of alluvial valley floors. Furthermore, the land near the mountains does not have extensive coal beds such as are present in the basin. Therefore, less surface mining of coal will occur where the minerals are privately owned.

The large proportion of Federal mineral ownership will affect the future of the area, because of the method in which coal tracts are selected for leasing. The U.S. Bureau of Land Management makes tract selections and evaluates the tracts according to several suitability criteria. Scenic value, critical habitat for endangered or threatened plant and animal species, alluvial valley floors, and municipal watersheds are only a few of the many items considered in determining if a Federal coal tract is suitable for mining. On April 28, 1982, in the largest sale of Federal coal leases in the history of the United States, 2.24 billion tons of coal in the Powder River structural basin were offered for sale by the Bureau of Land Managemint. 


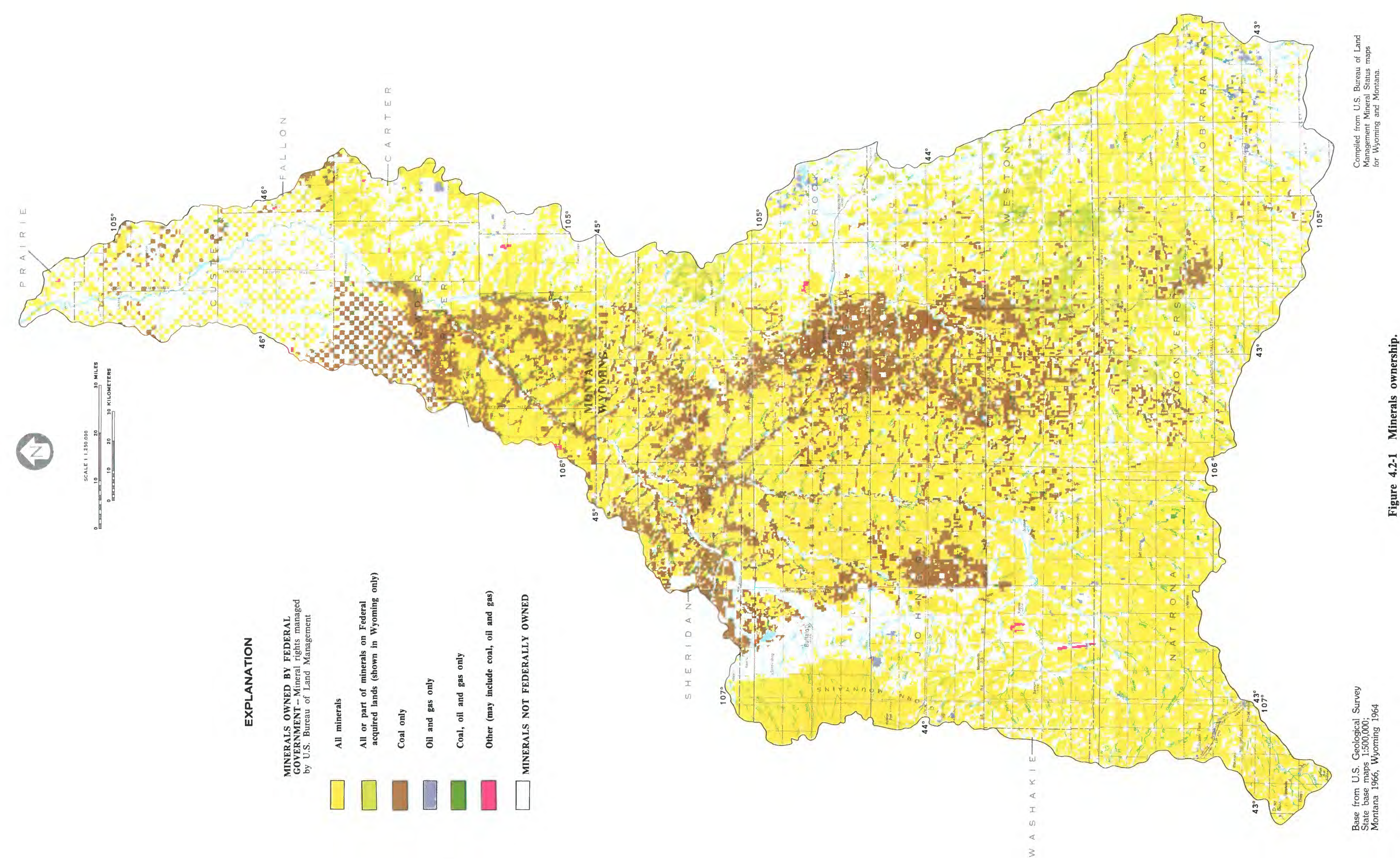




\title{
4.0 ECONOMIC DEVELOPMENT--Continued
}

4.3 Land and Water Use

\section{Agriculture Greatest User of Land and Water}

\author{
Nearly 90 percent of the land in Area 50 is used for agricultural purposes-- \\ mostly livestock grazing; 92 percent of the water used is for irrigation.
}

Livestock grazing on private and public lands is common throughout the area. The large proportions of land used for agriculture in Johnson and Campbell Counties are illustrated in figure 4.3-1; the proportions are similar in others parts of the area. The average ranch size in Campbell County is 7,451 acres (U.S. Department of Commerce, 1981). The average livestock densities are small, because 50 acres or more of rangeland may be required to meet the annual forage requirements for one cow. Agricultural and other land uses for the eastern one-half of Area 50 have been mapped at a scale of 1:250,000 (U.S. Geological Survey, 1979a, 1979b, 1979c, 1979d, 1980a, 1982).

Urban areas comprise a small proportion of the land use. The largest city in the area is Gillette (population 12,134), in Campbell County, Wyo. The population of Campbell County nearly doubled between 1970 and 1980; the average population density in the county as of 1980 was 5.1 persons per square mile (Wyoming Department of Administration and Fiscal Control, 1981). The magnitude of population growth resulting from energy-minerals development has caused an increased emphasis on regional, county, and city land-use planning. Examples of land-use plans are the City of Gillette/Campbell County Comprehensive Planning Program (City of Gillette/ Campbell County Planning Commission and City of Gillette/Campbell County Department of Planning and Development, 1978), and Wyoming Land Use Decisions (U.S. Bureau of Land Management, 1979).

Recreational land uses such as hunting, fishing, and fuelwood gathering in the Bighorn Mountains are popular on public and private lands. For example, Strickland (1981) reported more than 16,000 hunter-days and a success rate of more than 80 percent for antelope hunters in Johnson and Campbell Counties.

The most common industrial land use in the area is for mineral development. The 12 mines operating during 1980 will disturb 52,143 acres of the land surface during mining. The area of mining at any one time, however, is much less, and reclamation follows initial disturbance by about 5 years. A north-south railroad across Area 50 was built beginning in the early 1970 's specifically for coal development. The 113-mile line is the longest continuous, new track built in the United States since the 1930's. Two coal-fired powerplants in the area are supplied from nearby mines. Oil-and-gas fields are located throughout the basin, but are most numerous in the eastern part. Naval Petroleum Reserve Number 3 (which was the focus of the Teapot Dome oil scandal during the 1920's) is located in the southern part of the area, near the town of Midwest. Bentonite clay is mined near Kaycee.

More than 90 percent of the total water use in Area 50 is for irrigation. Surface- and ground-water use for irrigation, municipal, rural, and industrial supplies is illustrated in figure 4.3-2. The surface water used for irrigation is usually applied to hayfields along stream channels. Very few other irrigated crops are grown. Dryland winter wheat is grown in a few areas.

Water use for municipal and rural supplies is relatively small. Most municipal supplies are obtained from ground water; rural supplies are obtained in approximately equal proportions from ground water and surface water.

Water for industrial use is drawn mostly from ground water. Water may be injected in wells to increase oil production or to dispose of saline wastewater. The principal source of water for the Wyodak powerplant near Gillette is sewage effluent from Gillette.

Agricultural and industrial land and water uses commonly overlap (fig. 4.3-3). Jacobs and others (1982) prepared a detailed assessment of the transfer of land from agriculture to industry, the competition between agriculture and the coal industry for land and water, and the physical and economic impacts on agriculture as the result of coal development in the Powder River Basin. 

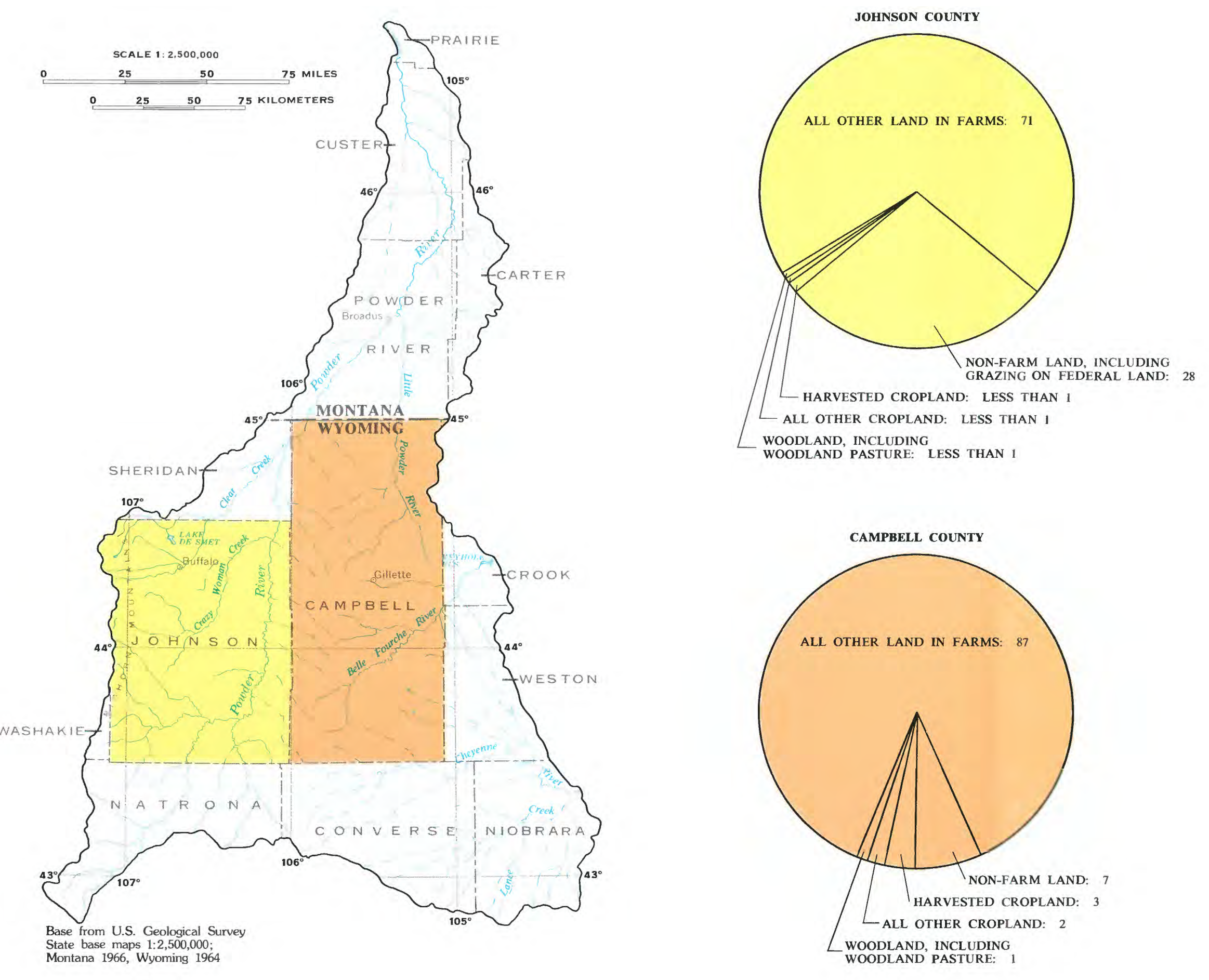

LAND USE BY COUNTY, IN PERCENT Percentages modified from Wyoming
Department of Adminisistration and Fiscal Control (1981).

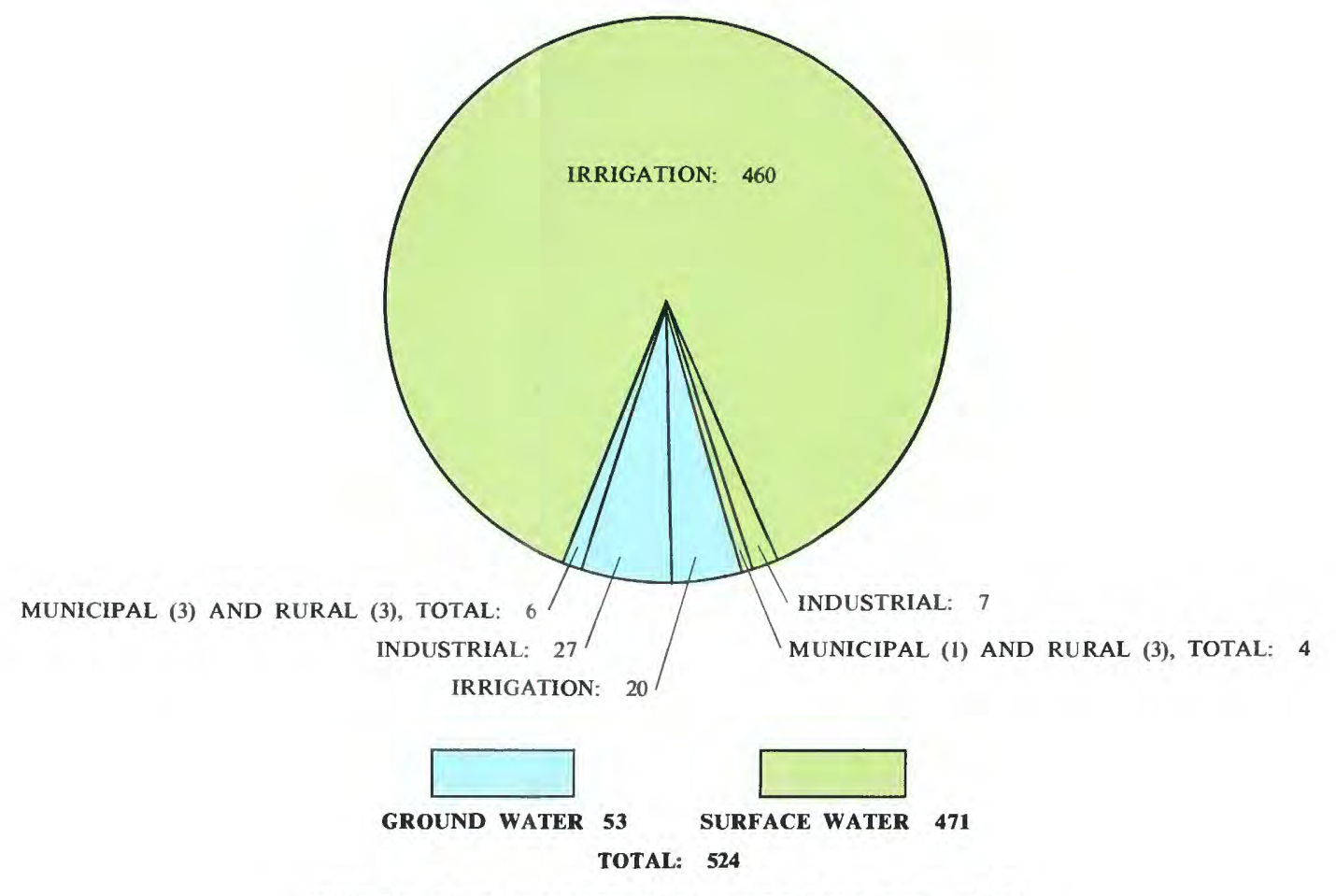

WATER USE, IN MILLION GALLONS PER DAY

Figure 4.3-2 Approximate water use during 1980.

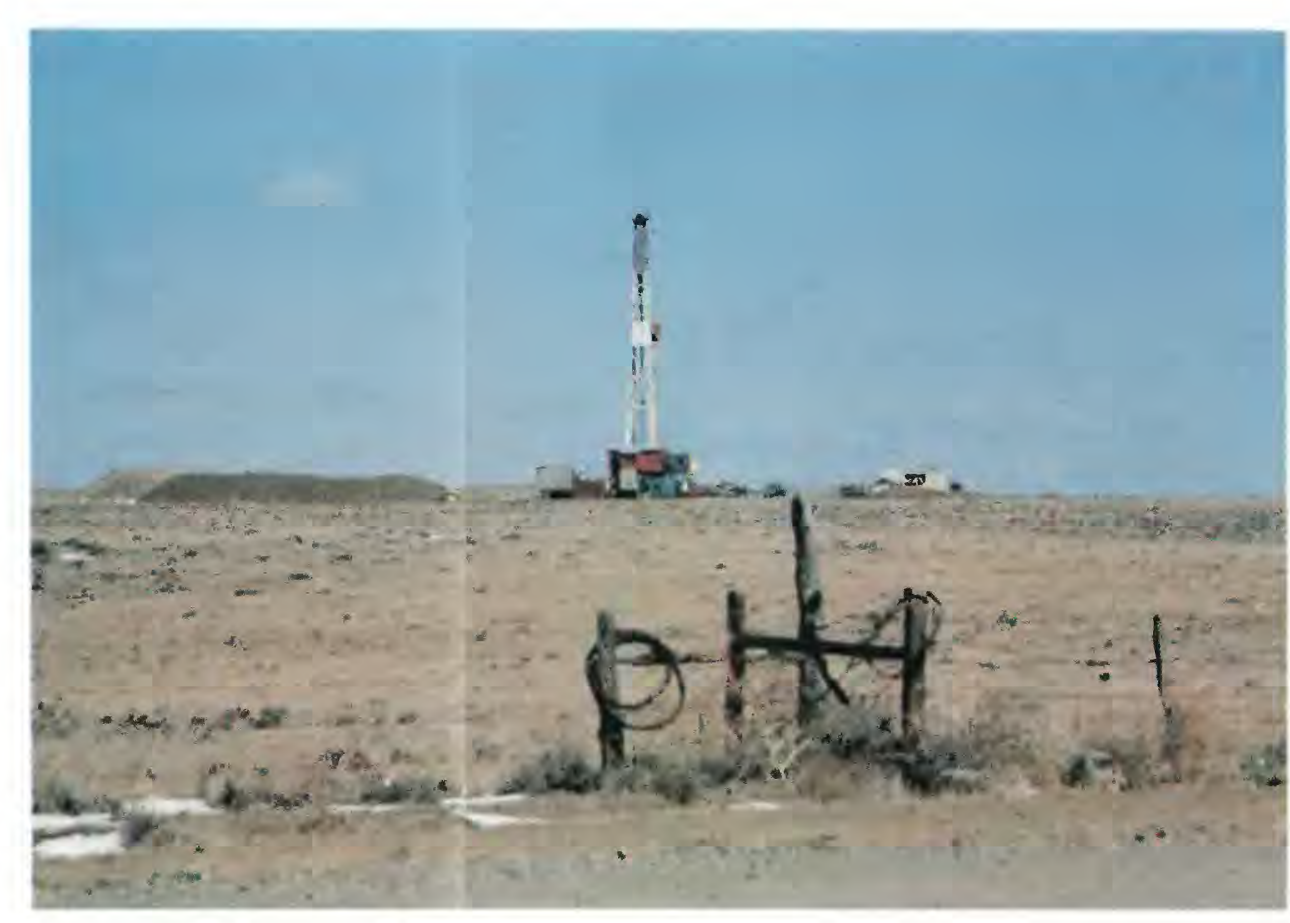

Figure 4.3-3 Agricultural and industrial uses of land and water commonly overlap. 
4.0 ECONOMIC DEVELOPMENT--Continued

4.4 Coal

\title{
Area 50 Contains More Coal than Any Other Hydrologic Area in the Nation
}

\author{
Coal production has increased from less than 1 million tons in 1970 to \\ 81.2 million tons in 1982; production in 1990 is projected to be 122 million tons.
}

Coal resources underlying Area 50 probably exceed 500 billion tons. Of this estimated resource, at least 24.5 billion tons are currently (1983) defined as strippable reserve base; that is, that part of the resource from which recoverable strippable reserves will be derived (Glass, 1982; Matson and Blumer, 1973). These 24.5 billion tons are a conservative estimate that will increase as more detailed geologic reports are published.

The reserve base for coal that may be recoverable by underground mining techniques also is extremely large in the area--about several tens of billions of tons. Because the last comprehensive coal-resource estimate for this area was made in 1950 (Berryhill and others, 1950), more accurate estimates of resources and reserve base must await new studies based on private and government coal drilling during the last 15 years and on extensive oil-and-gas drilling records for the last 30 or more years. New coal-resource estimates, however, are available for some smaller parts of the area (Denson and Keefer, 1974; Denson and others, 1978; and Grazis, 1977a, 1977b, 1977c, 1977d).

Coal production from Area 50 has increased phenomenally during the last 12 years. (See figure 4.4-1.) In 1970, two strip mines were active in the area. Of the 640,000 tons produced by those two mines, the Wyodak Mine accounted for all but 2,179 tons. By 1982, 13 large strip mines were active in the area, and collectively, these mines produced 75 percent (81.2 million tons) of Wyoming's total coal production (108 million tons) during that year (fig. 4.4-2). Two of these strip mines (Thunder Basin Coal Company's Black Thunder Mine and Amax Coal Company's Belle Ayr Mine) produced 16.8 million tons and $\mathbf{1 5 . 2}$ millions, respectively. These two mines, incidentally, are the largest coal mines in the United States. Although the Belle Ayr mine shown in figure 4.4-3 was the second largest mine in 1982 , its 1978 production of 18.1 million tons is still the Nation's record annual production from a single coal mine. Although demand for coal from Area 50 is forecast to exceed 122 million tons per year by
1990 , annual mine capacity in the area could approximate 200 millions tons by that same year (Glass, 1980a).

All the active coal mining in the area is restricted to the outcrop of the Wyodak coal bed in eastern Campbell County, Wyo. (fig. 4.4-2). Strip-mine operations extracted 81.2 million tons of coal from this bed during 1982, which is the largest tonnage from a single coal bed in the Nation. This annual production also ranks Campbell County as the largest coal-producing county in the United States--a title the county could hold for many decades, if not centuries. During 1981 only four coal-producing States (Kentucky, West Virginia, Wyoming, and Pennsylvania) produced more coal than Campbell County.

The present demand for Area 50 coals began during the late 1960's as electric utilities searched for low-sulfur coals that they could burn in their powerplants and meet mandated emission standards. Today, nearly all the coal mined in this area is burned in coal-fired electrical powerplants in at least 16 States as far west as Oregon, as far east as Ohio, and as far south as Texas and Louisiana. Only about 1.5 million tons, or 1.8 percent of the coal from the area, are used for industrial purposes (beet sugar, bentonite, and cement industries) or retail sales for home, business, and municipal heating.

Although only one coal-fired powerplant (330-megawatt Wyodak plant) is located in the area, others have been proposed. In addition, the area has been named as a possible site for several proposed coal-conversion plants (a facility that converts coal into synthetic gas or into synthetic liquids or both). At two separate test sites in the area (Lawrence Livermore's Hoe Creek site and Atlantic Richfield's Rocky Hill No. 1 site) thick Tertiary coals have been converted into low-energy synthetic gas by in situ (underground) combustion experiments (fig. 4.4-2). The huge coal resources of the area will continue to make Area 50 a potential site for such facilities. 


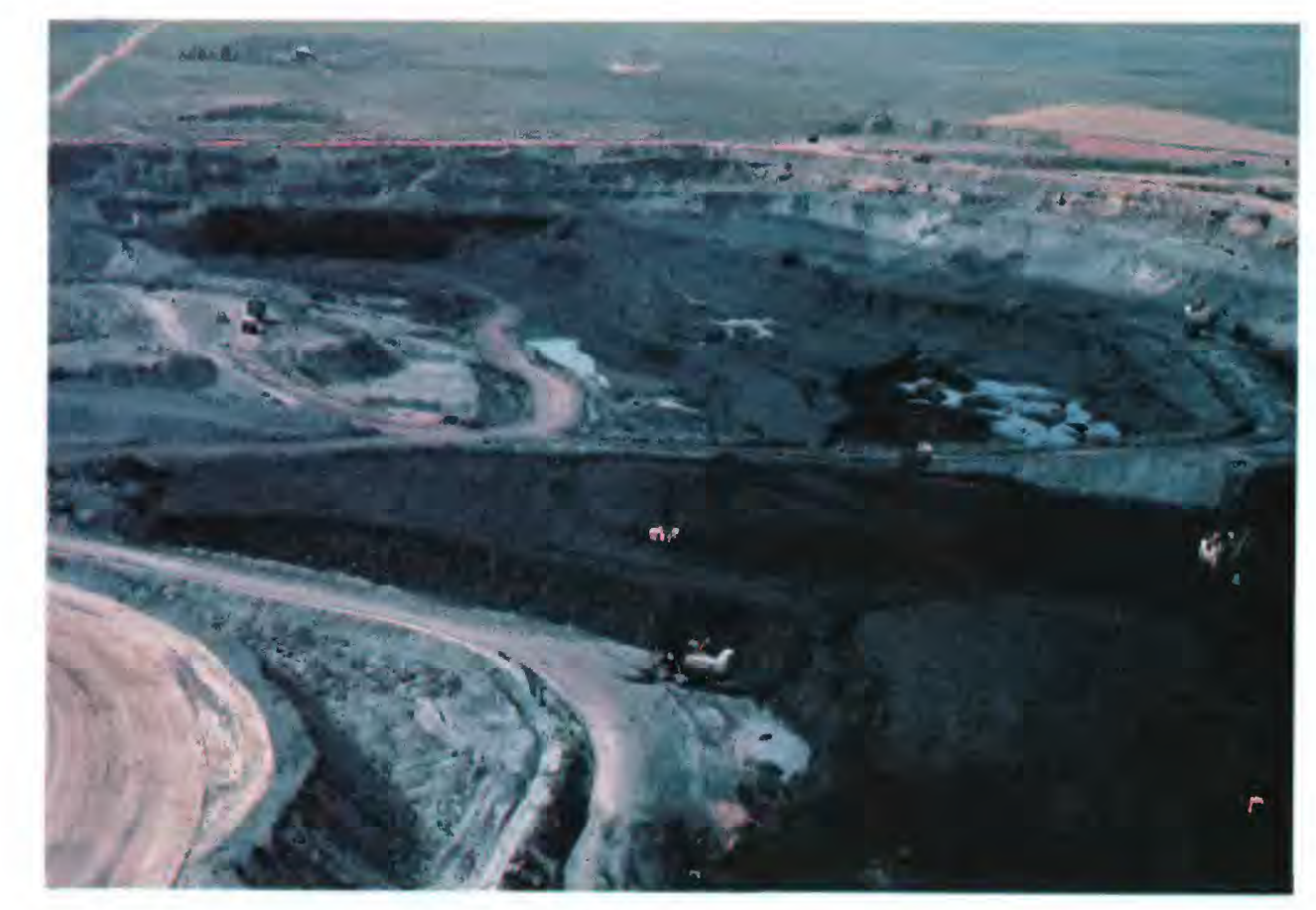
Figure 4.4-3 Belle Ayr Coal Mine. Average production for 1973-82 was 11.7 million
tons per year. Peak production in 1978 was 18.1 million tons, a record for the Nation.

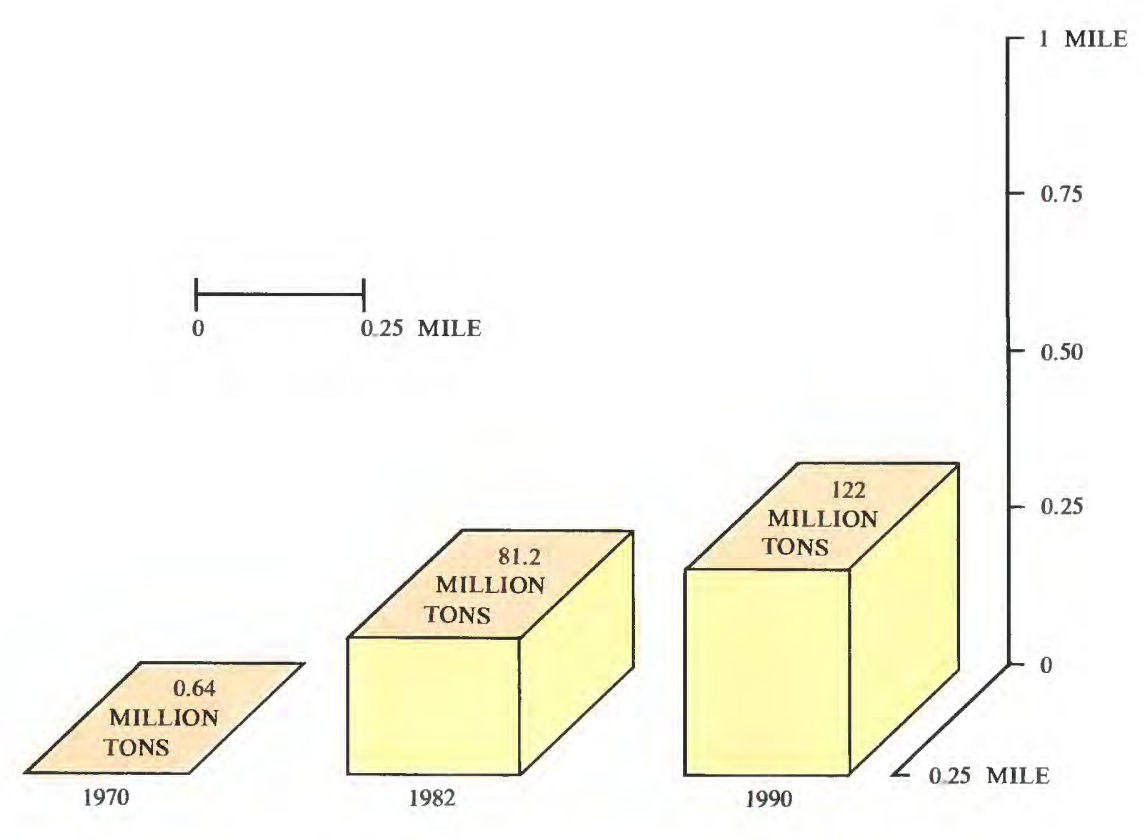

Figure 4.4-1 Tonnage and approximate volume of coal

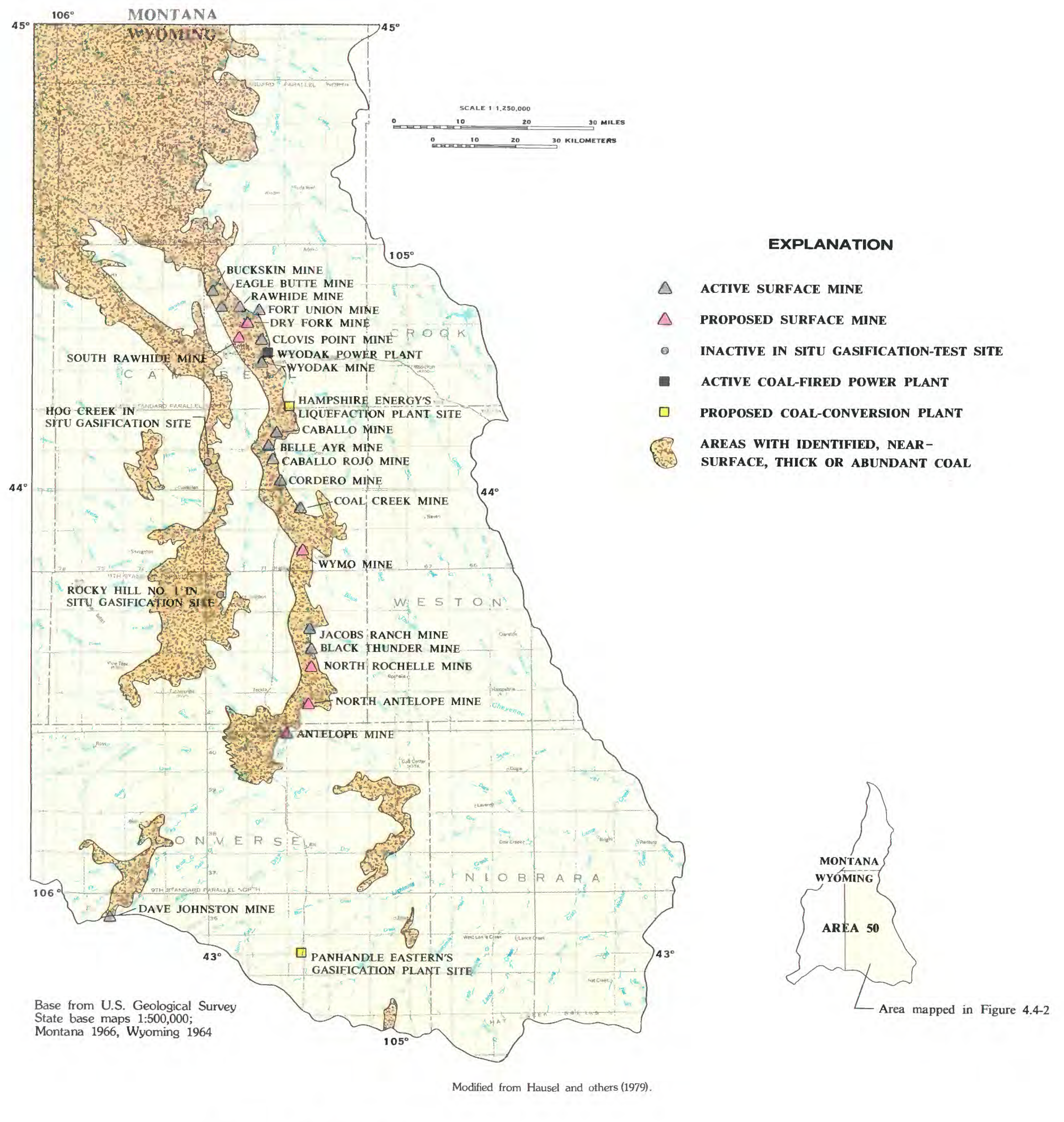

Figure 4.4-2 Minerals ownership. 


\title{
4.0 ECONOMIC DEVELOPMENT--Continued
}

4.5 Other Mineral Resources

\section{Oil, Natural Gas, Uranium, Bentonite, Gypsum, Limestone, and Metals also are Important Resources in the Area}

\author{
Petroleum products are produced from wells and underground mines; uranium is produced \\ from surface and underground mines as well as from in situ leaching processes.
}

During 1981, about 47 million barrels of petroleum and about 54 billion cubic feet of natural gas were produced in Area 50 from fields shown in figure 4.5-1. These amounts were about 38 percent of the State's oil production and about 12 percent of the State's gas production. The production was from about 500 oil-and-gas fields, which are located mostly in the eastern one-half of the area (fig. 4.5-1). Oil and natural gas exploration in this area has been so prolific in recent years that at least one new field has been discovered each month. Although drilling has decreased since 1982, more wells are drilled in this area each year than in any other area of the State. For a recent summary of the oil-and-gas industry in Wyoming, see Ver Ploeg (1982).

All the oil and natural gas that has been commercially developed was from formations older than the Upper Cretaceous Fox Hills Sandstone. Oil and gas wells completed in these formations also produced more than 250 million barrels of water each year. Although some of this water is simply reinjected into disposal wells, most of the water is used for secondary and tertiary waterflood projects.

Recently there has been commercial interest in the gas in thick Tertiary age coal beds that underlie the area. The coal gas is principally methane with some light hydrocarbons (Whitcomb and others, 1966, p. 70-71; Lowry and Cummings, 1966, p. 46-48). Some coal gas that is discharged from water wells has been reported to be used for domestic use, but most gas that is produced that way escapes into the atmosphere. The ignited gas at a stockwater tank in southeastern Sheridan County, Wyo., is shown in figure 4.5-1.

The area also contains the sites of one active and another proposed underground mine for the recovery of heavy oil. Conoco's underground mine in the North Tisdale field near Kaycee, Wyo. (fig. 4.5-1), produced 10,418 barrels of heavy oil during 1981 . Conoco has a second mine under construction near Linch, Wyo., which is 20 miles east of their active mine.
Currently (1983) two uranium mines in the area are active; however, 10 mines that are closed or postponed can reopen or resume construction if the demand and price of uranium oxide increase (fig. 4.5-2). During 1981 six active mines or in-situ leach operations produced 1.3 million tons of uranium ore. By 1982 production decreased to an estimated 1 million tons. Numerous prospects and abandoned uranium mines from the 1950's and early 1960's are present in the southern part of the area, and many uranium-ore deposits have been reported (Hausel and others, 1979).

Bentonite is another important mineral resource in the area. This clay mineral is used primarily for well-drilling mud, for pelletizing taconite (iron ore), and for foundry castings. Kaycee Bentonite Company operates the active mines in the southwestern part of the area. Bentonite-bearing strata also crop out in the southeast along the Old Woman anticline and in the northeast along the western edge of the Black Hills uplift (fig. 4.5-2).

Gypsum-bearing rocks are present on the flank of the Bighorn uplift on the west side of the area (fig. 4.5-2). An abandoned gypsum mine is located in T. 53 N., R. 83 W. (Hausel and others, 1979). No gypsum is presently (1983) produced in Area 50; however, Wyoming's largest gypsum-producing region is just west of the Bighorn Mountains.

Limestone crops out along both the east and west margins of the area (fig. 4.5-2). Several small quarries are present in these units, but limestone is not presently (1983) produced within Area 50. These limestones are quarried in adjacent regions. Limestone is, however, an important resource of the area.

A few prospects for metals (gold, copper, tungsten, manganese, and rare earths) are found in the Bighorn Mountains on the west side of Area 50 (fig. 4.5-2). No major production has been reported from any of these prospects. 


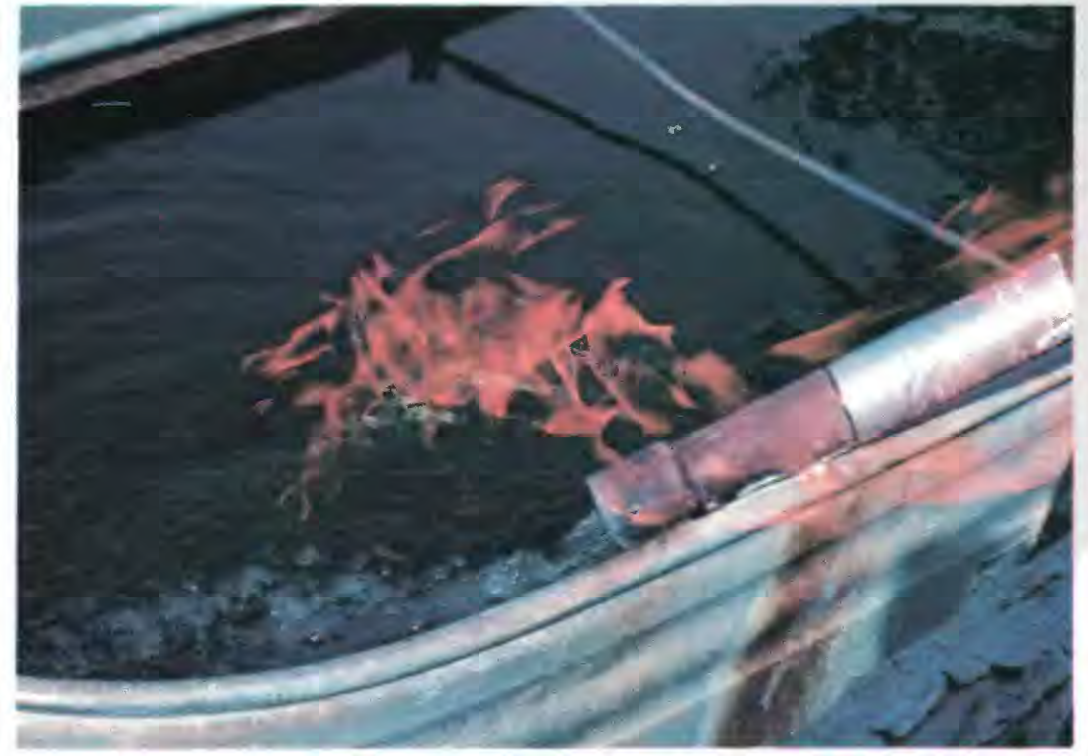

Burning coal gas at artesian water well in southeast Sheridan County, Wyoming.

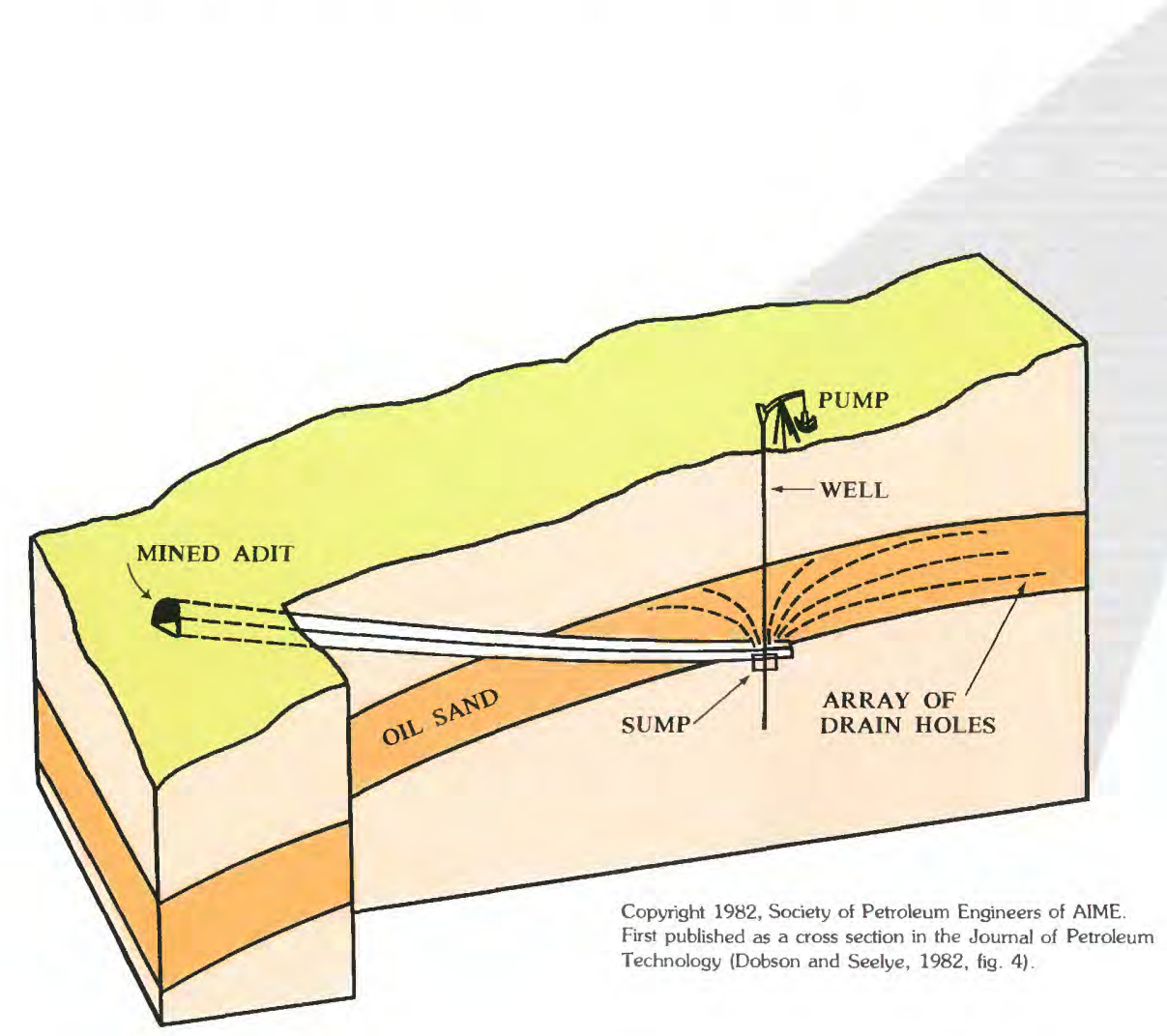

Diagram of oil mine near Kaycee, Wyoming; not to scale.

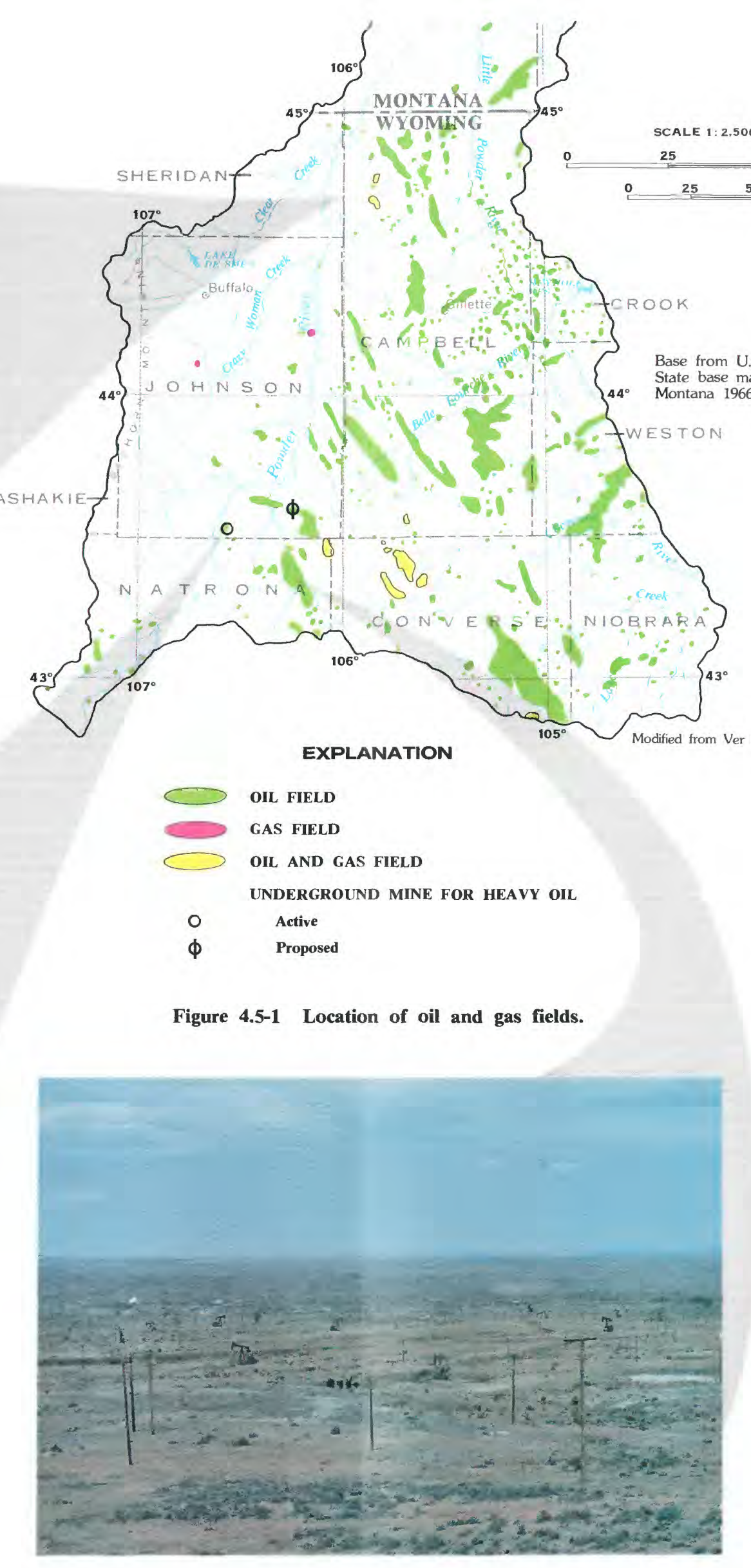

Salt Creek oil field.

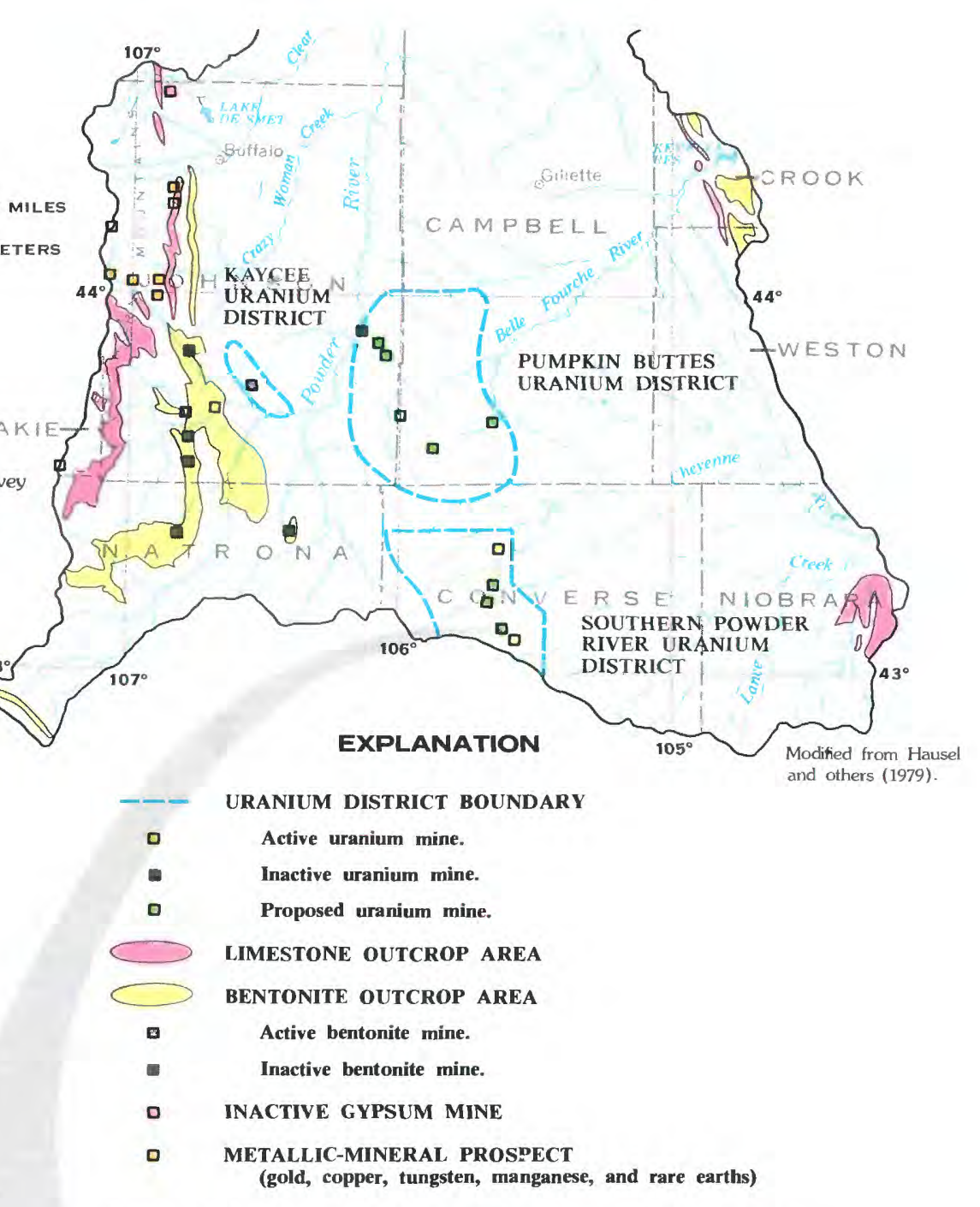

Figure 4.5-2 Location of uranium, limestone, bentonite, Figure 4.5-2 Location of uranium,
gypsum, and metallic-mineral resources.

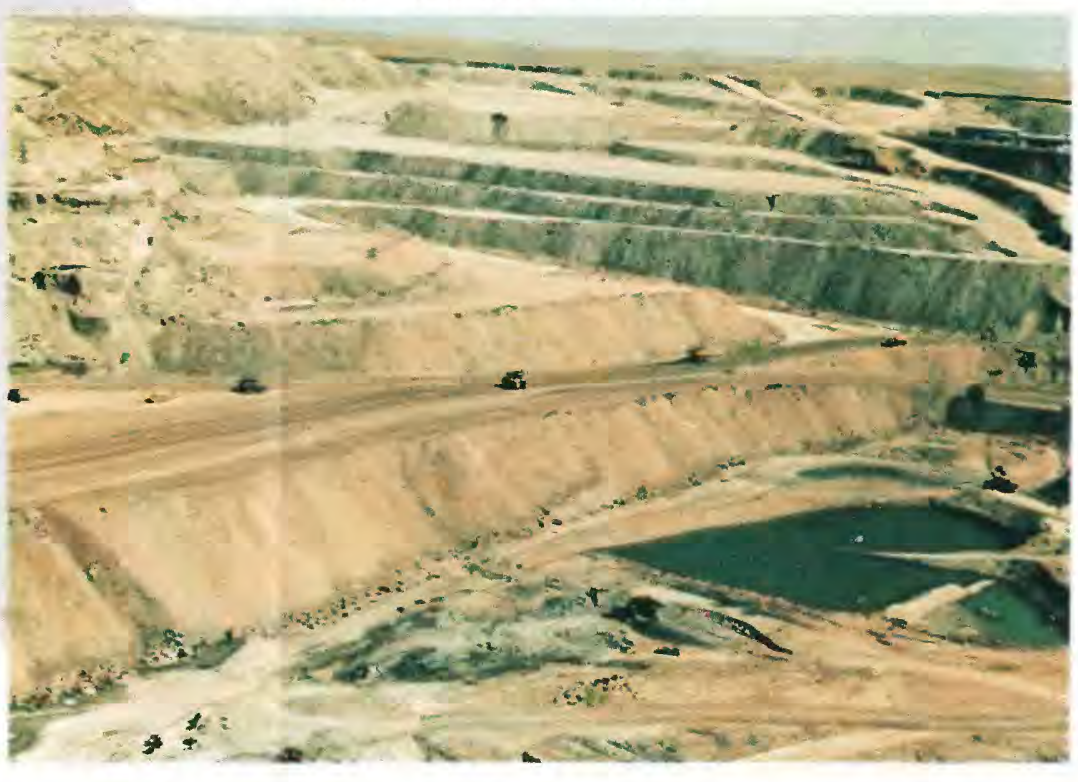

Exxon's Highland uranium mine.

4.0 ECONOMIC DEVELOPMENT--Continued 


\title{
Hydrologic Data Available for 168 Surface-Water Locations
}

\author{
Surface-water data are available for 168 locations in Area 50; 132 have \\ streamflow data, 81 have chemical-quality data, 42 have fluvial-sediment \\ data, and 67 have biological data.
}

\begin{abstract}
Data collection in Wyoming is a cooperative effort in which the planning and financial support are shared with the U.S. Geological Survey by State and local governments, and other Federal agencies. The locations of stations and sites where surfacewater data have been collected are shown in figure 5.0-1. Additional information about the name, location, and records available for each station and site is given in section 10.3 of this report.
\end{abstract}

A station is a location where continuous or repetitive records of streamflow or water quality have been collected; a site is a location where miscellaneous discharge measurements or water-quality samples have been obtained. To simplify the identification of the locations shown on the maps in this report, including figure $5.0-1$, the stations and sites have been assigned individual numbers, from 1 to 168. These numbers are used throughout this report, instead of the Geological Survey 8-digit station numbers (see list in section 10.3). For example, station 1 in figure 5.0-1 has a Geological Survey downstreamorder station number 06309200; site 154 has none. When requesting additional information about the records for a station, use the Geological Survey station number.

Continuous records of streamflow have been collected at 117 gaging stations. At such installations a continuous record of gage height (stage) is recorded. Discharge is periodically measured with a current meter. The measurements are used to develop a stage-discharge relationship with which discharge can be determined for any stage of the stream. Application of the relationship to the continuous record of stage yields streamflow values that are expressed as average rates or volumes of flow for each day. Maximum and minimum instantaneous flow rates also are determined.

At some stations only peak-flow data are collected. These are known as crest-stage stations. A protected staff gage at these stations records the maximum stages of floods. A stage-discharge rela- tionship is developed for each station and the peak discharge is determined for each maximum recorded stage.

During 1965-73, a network of special gaging stations was operated as part of a study of flood hydrographs for small drainage basins. At these stations, continuous records of rainfall and resulting runoff were collected during the rainfall season, May through September (Rankl and Barker, 1977). A mathematical model was used to extend the records of floodflows at these sites (Craig and Rankl, 1978).

Special studies sometimes require discharge measurements to be made at sites where streamflowgaging stations have not been installed. For example, seepage studies to determine water loss or gain through a particular reach of stream, and collection of water samples at ungaged sites generally require a measurement of discharge. Fifteen sites listed in section 10.3 have this type of streamflow record.

Water samples have been collected at many of the stations and sites shown in figure 5.0-1. Chemical-quality data are available for 81 locations, fluvial-sediment data for 42 locations, and biological data for 67 locations.

The concentrations of dissolved and suspended material in streamflow change with season of the year and magnitude of the discharge. A single sample defines the kinds and concentrations of material only at the time of sampling. For surface-water quality to be defined for a specified time and for a range of discharges, water samples generally are collected periodically.

Records of streamflow and water quality are published in annual reports of the U.S. Geological Survey (1983a, 1983b). They also may be retrieved through computerized systems that are described in section 9.0 of this report. 


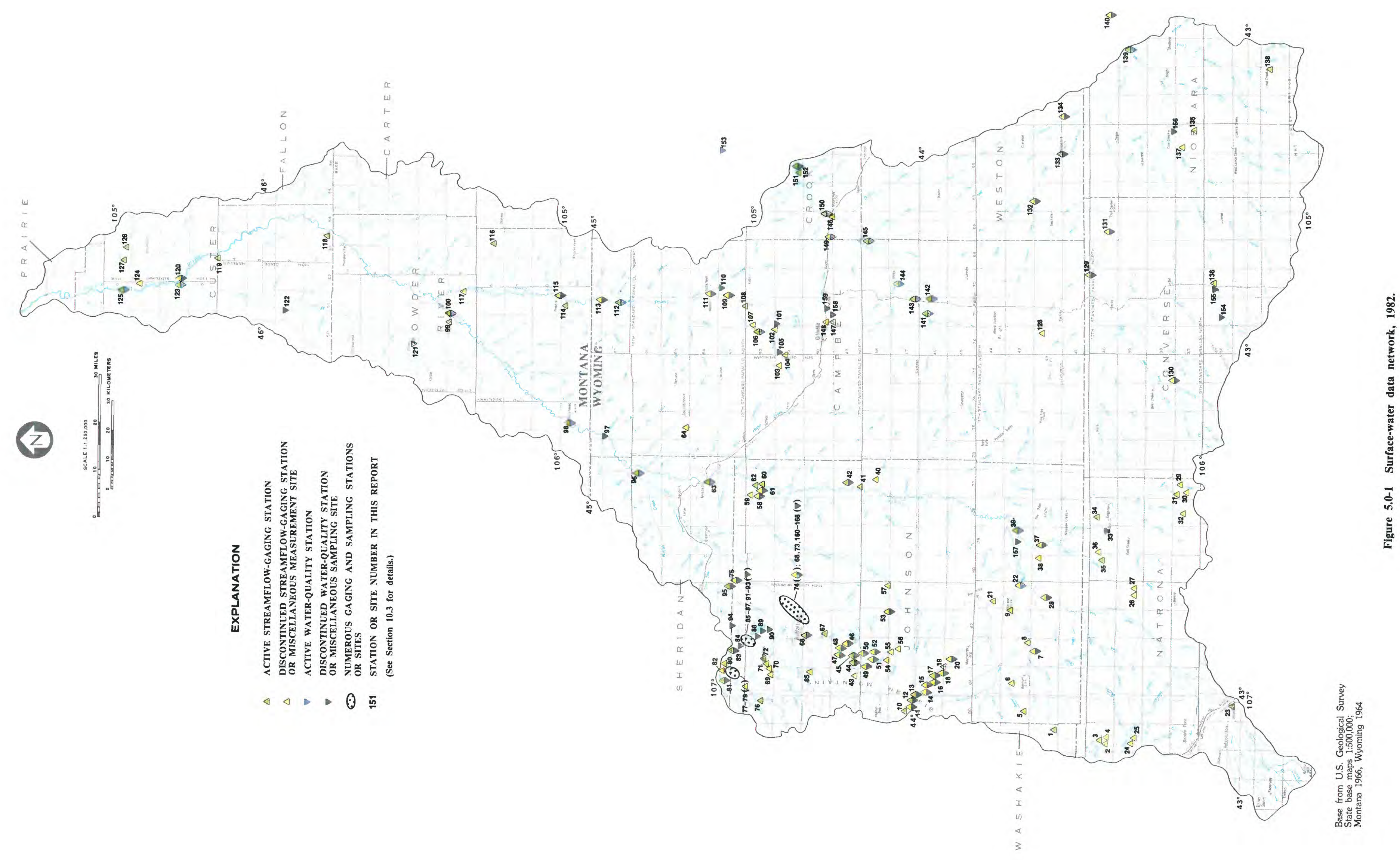




\subsection{SURFACE-WATER QUANTITY \\ 6.1 Average Flow}

\section{Mountain Areas Produce Much Greater Runoff than Plains Areas}

\section{Average annual runoff per square mile exceeds 200 acre-feet in mountain areas and is less than 10 acre-feet for the semiarid plains.}

\begin{abstract}
Average annual runoff, in acre-feet per square mile, was computed using streamflow data collected at 40 gaging stations in Area 50. Values of average annual runoff range from 2.21 to 760 acre-feet per square mile. The data were divided into six groups and each group was assigned a color; the results are presented in figure 6.1-1.
\end{abstract}

Average annual runoff in the mountain streams is a function of climatic factors and physical characteristics of the basins. Important climatic variables are precipitation, temperature, wind, evaporation, and solar radiation. Climatic conditions of a mountain basin are related to the avearage basin elevation and the basin's relative position in the mountain range. The most important physical characteristic is the drainage basin size. Moisture storage in the form of lakes, ponds, and aquifers has some effect on total runoff, but to a much lesser degree than the climatic conditions and the drainage area.

Average annual runoff of a plains-area stream is a function of quantity and intensity of precipitation, drainage area, evaporation, evapotranspiration, and permeability of the surfical material. Rainstorm intensities or snowmelt rates that exceed the infiltration rate of moisture into the surfical material produce runoff. The contribution of discharge from ground water to plains-area streams is minor. Manmade drainage structures, stock ponds, and irrigation works decrease the total runoff from a basin by increasing the time for water losses due to evaporation and evapotranspiration, as well as by retention of water for consumptive use.

Average annual flow, in cubic feet per second, can be estimated for ungaged sites in Area 50 by using regression equations developed by Lowham (1976, p. 23). He developed equations for the perennial streams in mountain areas by relating runoff to the drainage area and average basin elevation. Average annual runoff for plains-area basins was related only to drainage area. These equations were developed for Wyoming but are applicable to the Montana part of Area 50. 


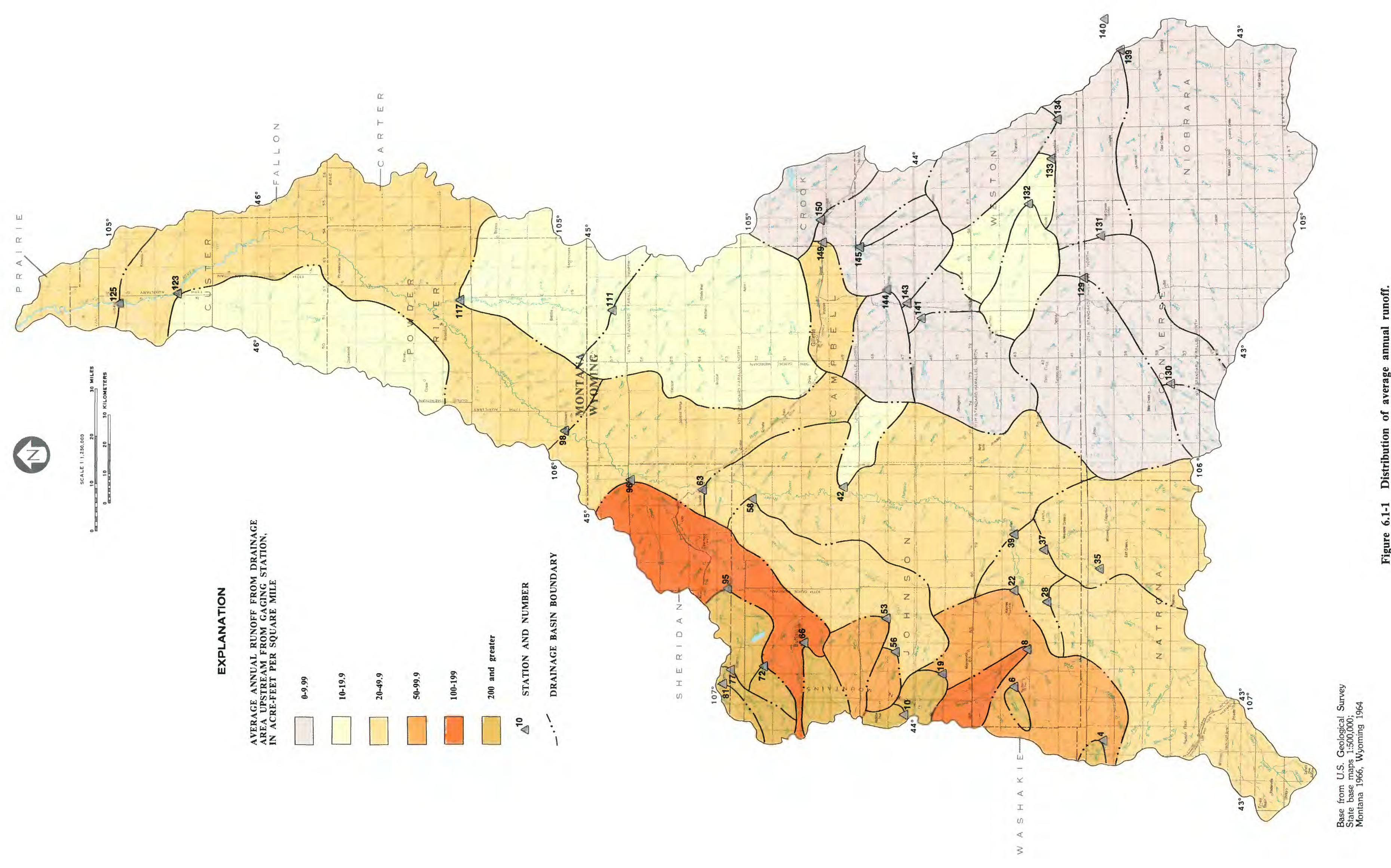




\title{
6.0 SURFACE-WATER QUANTITY--Continued \\ 6.2 Streamflow Variability
}

\section{Streamflow More Variable in Plains Areas than in Mountain Areas}

\begin{abstract}
The large variability of streamflow in the plains areas is a result of variable precipitation, little infiltration, and negligible moisture storage; mountain runoff is less variable because of moisture storage in snowpacks and aquifers.
\end{abstract}

Hydrographs of maximum, minimum, and average daily streamflows for an ephemeral stream in the plains area and a perennial stream in the mountain areas are compared in figure 6.2-1. The hydrographs for Lance Creek near Riverview, Wyo. (station 139), an ephemeral stream, show a large difference between the maximum and minimum runoff values, high sharp peaks, an early snowmelt runoff, and many days of zero flow. The hydrographs for North Fork Powder River near Hazelton, Wyo. (station 10 ), a perennial stream, show less variability of runoff and a later period of snowmelt runoff than the ephemeral stream.

Streamflow hydrographs for the 1979 water year for an ephemeral and a perennial stream are illustrated in figure 6.2-2. Dead Horse Creek near Buffalo,
Wyo. (station 42), an ephemeral stream that drains 151 square miles of plains, shows one snowmelt runoff in March and three periods of rainfall runoff in the summer. The perennial stream, Clear Creek near Buffalo, Wyo. (station 66), which drains 120 square miles of mountain area, shows sustained ground-water discharge in the fall and winter and a large snowmelt runoff from April through June.

Long-term variability of streamflow is illustrated in figure 6.2-3. During 1944 the annual flow of the Powder River near Locate, Mont. (station 125) was 250 percent of the average flow for the period of record (1939-81 water years). During 1961 the annual flow was only 13 percent of the average flow. 


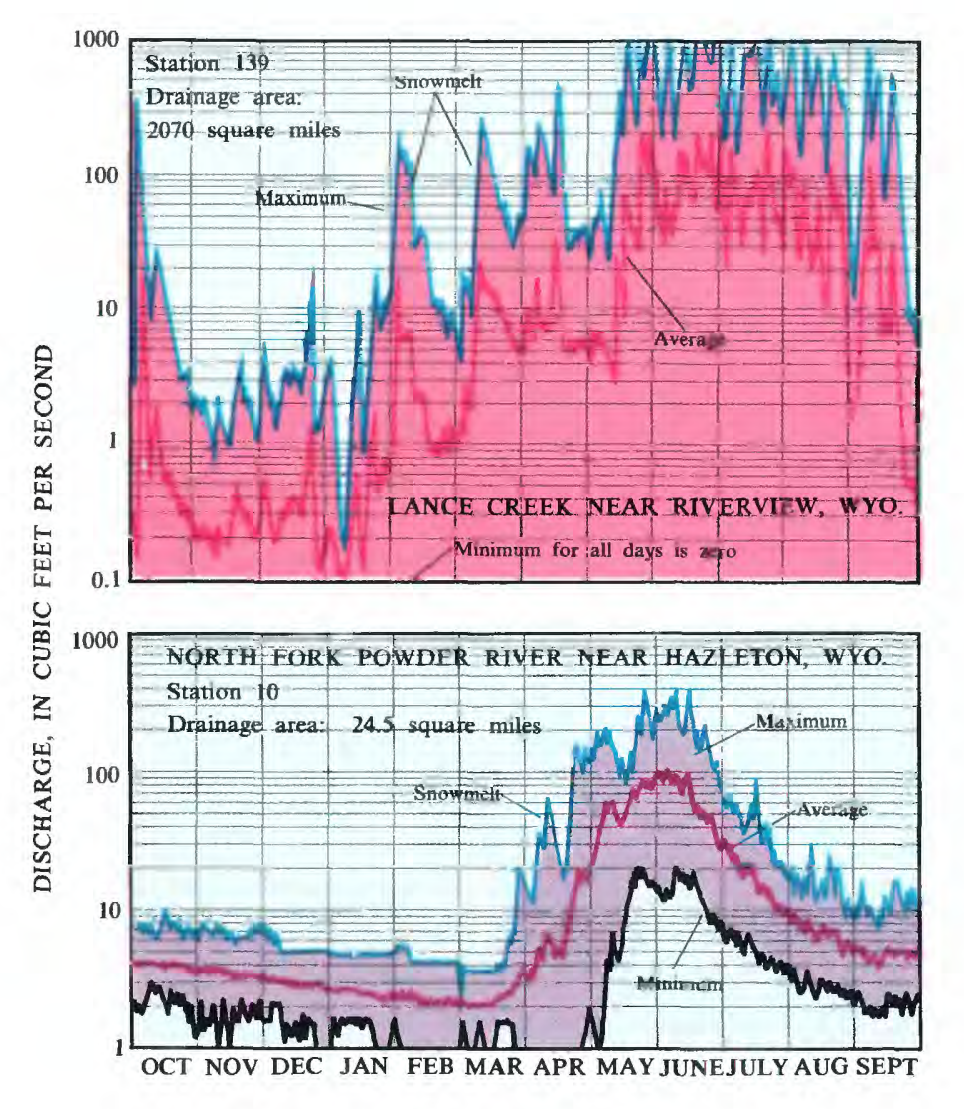

Figure 6.2-1 Maximum daily, minimum daily, and average daily streamflow hydrographs for selected stations, 1951-69 water years.
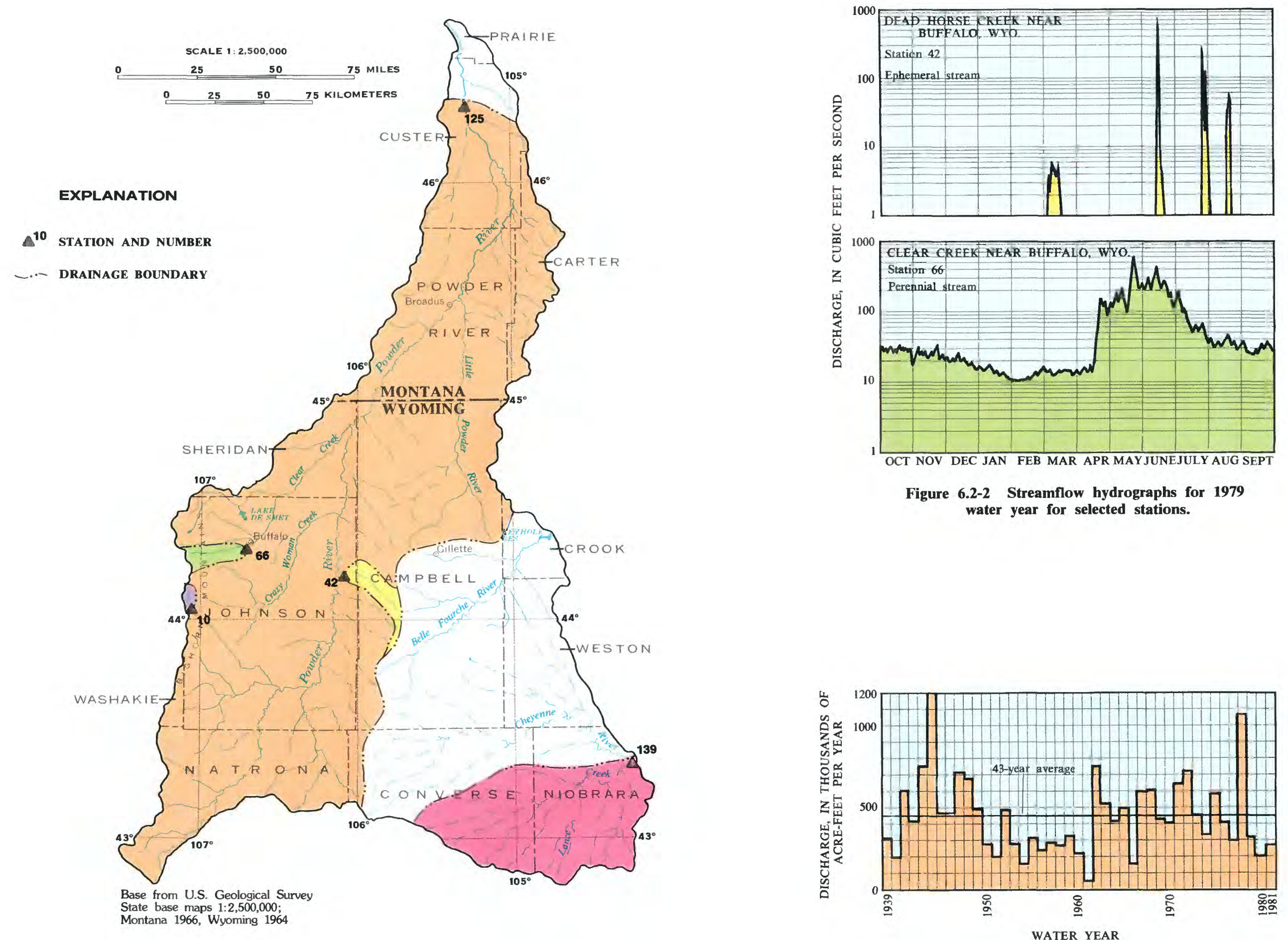

Figure 6.2-2 Streamflow hydrographs for 1979 selected stations.

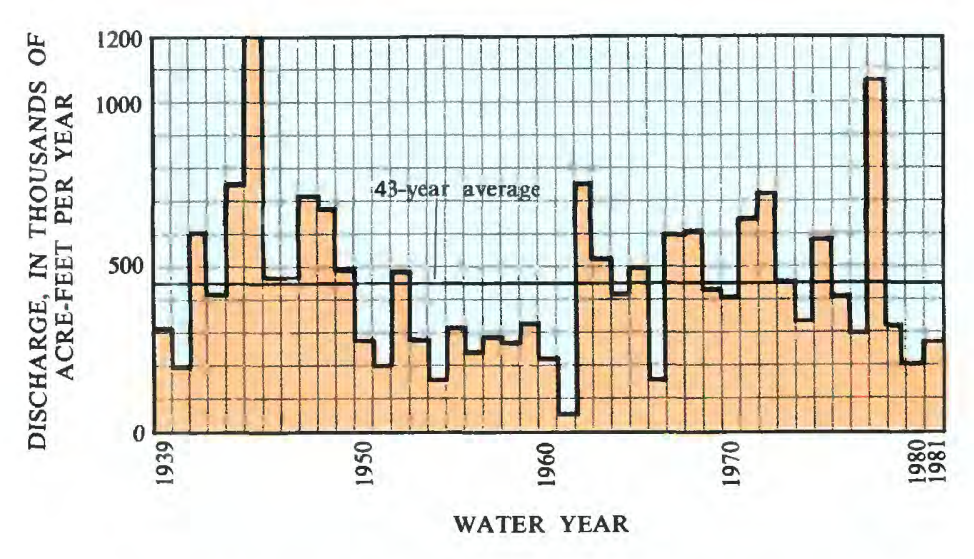

Figure 6.2-3 Annual discharge of Powder River near Locate, Montana (station 125), 1939-81 water years. 


\title{
6.0 SURFACE-WATER QUANTITY--Continued
}

6.3 Low Flow

\section{Low Flow is No Flow in Most Plains-Area Streams}

\author{
Because most plains-area streams flow only in response to rainstorms and \\ snowmelt they are dry most of the time; mountain streams flow during \\ most dry seasons and droughts.
}

Most plains-area streams are ephemeral and have long periods of no flow. Only the largest streams maintain flow for extended periods during most years. Some streams (called interrupted streams) on the plains intercept shallow aquifers or receive water from springs that provide perennial flows for relatively short reaches. Such flows do not continue far from their sources, because of infiltration and evapotranspiration; consequently, the streams cease flowing.

Minimum flows greater than zero in the mountains result from more precipitation, less evapotranspiration, and a larger capacity to store moisture. Moisture is stored in aquifers and near-permanent snowpacks and is released at a slow rate to sustain the streamflow.

Streamflow records for stations with 19 or more years of record were analyzed for 7-day low-flow statistics. The results of these analyses are listed in table 6.3-1.

The Powder River maintains flow most of the time throughout its course from the mountains to the Yellowstone River, 29.4 miles downstream from station 125, but its low-flow characteristics change as illustrated by the 7-day low-flow statistics presented in figure 6.3-1. The concave probability curve for station 22 shows that the perennial source of water is the mountains. Streamflow losses to irrigation, evapotranspiration, and to alluvial aquifers between stations 22 and 63 are exemplified by the convex shape of the low-flow probability curve at station 63 and the increase in the number of no-flow days.

A perennial source of water from the mountains enters the Powder River between stations 63 and 98 . The results are a less convex low-flow probability curve and fewer no-flow days at station 98 . Streamflow gains and losses between stations 98 and 125 are apparently about equal and, therefore, the low-flow statistics are similar for the two stations.

Low-flow statistics for station 81 are presented in figure 6.3-2 as an example of the type of information available for perennial streams in the area. These low-flow statistics provide information about water supply for municipal and industrial uses, irrigation, instream fisheries, and waste disposal.

Unfortunately, low-flow studies for ephemeral streams, which have zero flow for many days each year, have little value. Because streamflow in ephemeral and intermittent streams is so variable (section 6.1 ), the average annual flow of these streams (section 6.2) is also of little value when seeking a dependable water supply. A reservoir-storage frequency model has been developed by Glover (1984). The model evaluates the within-year and the between-year variability of streamflow for an ephemeral stream, and computes the probabilities of reservoir storage, including the risk of being unable to supply downstream demand. 


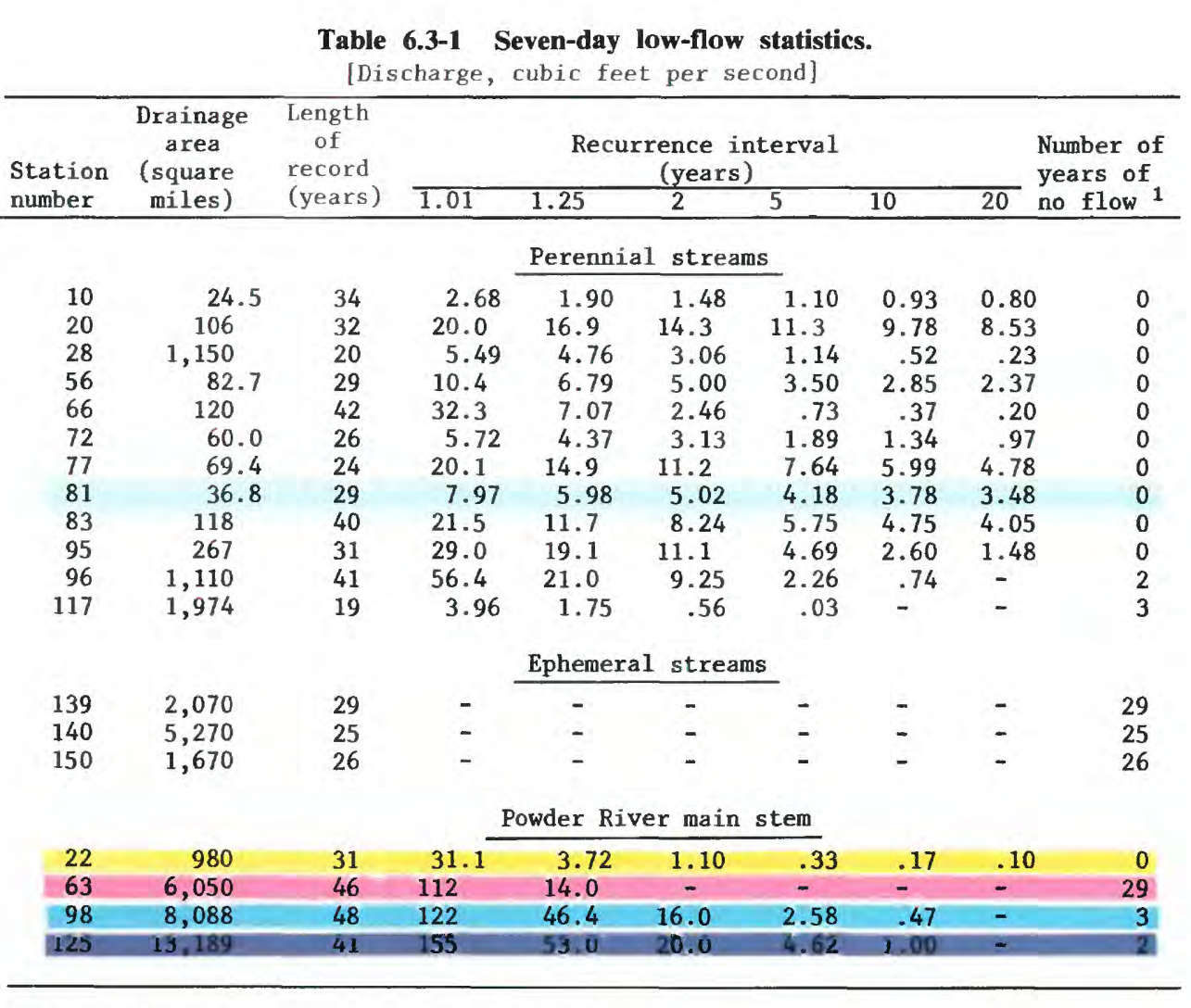

${ }^{1}$ Seven or more consecutive days of no flow

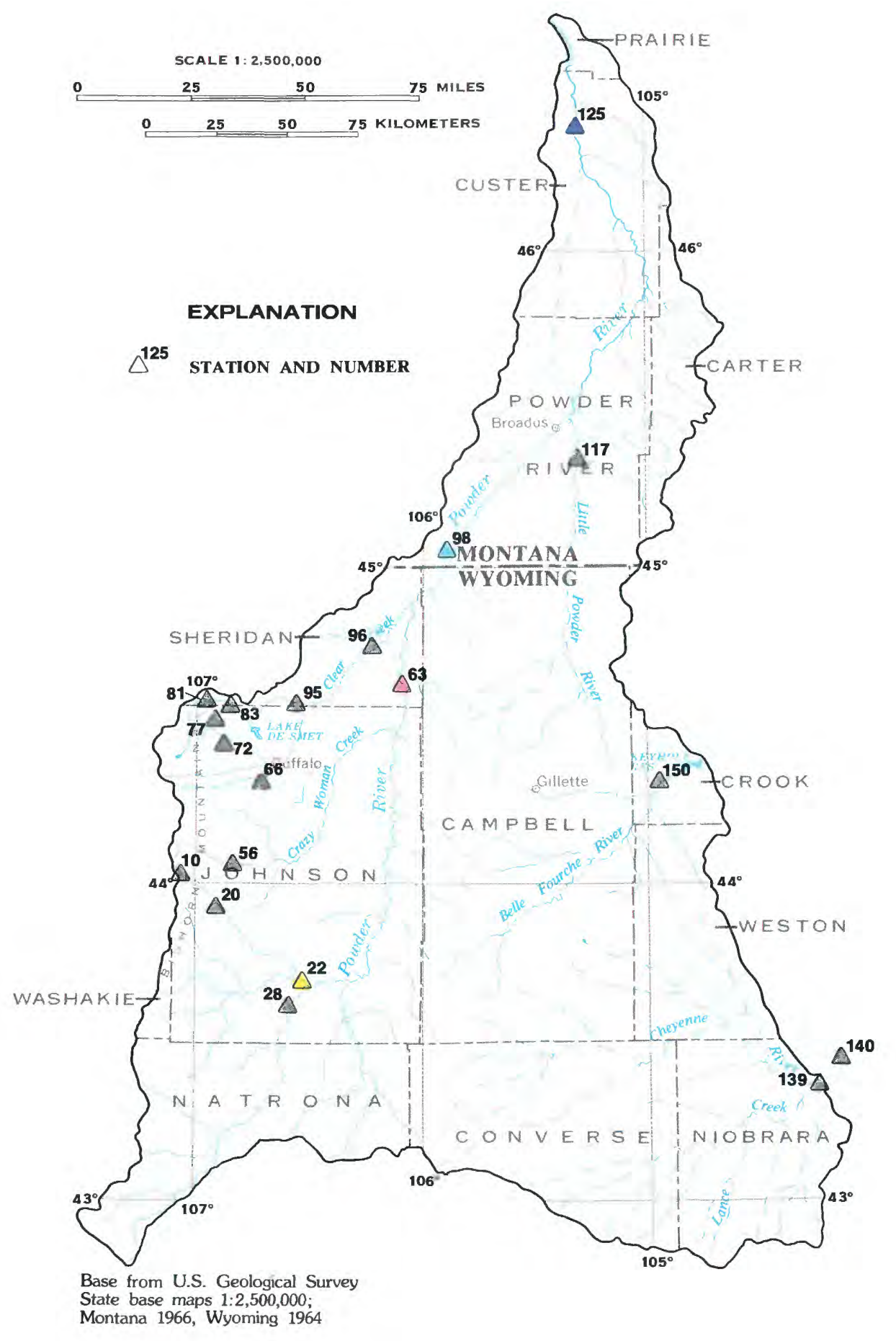

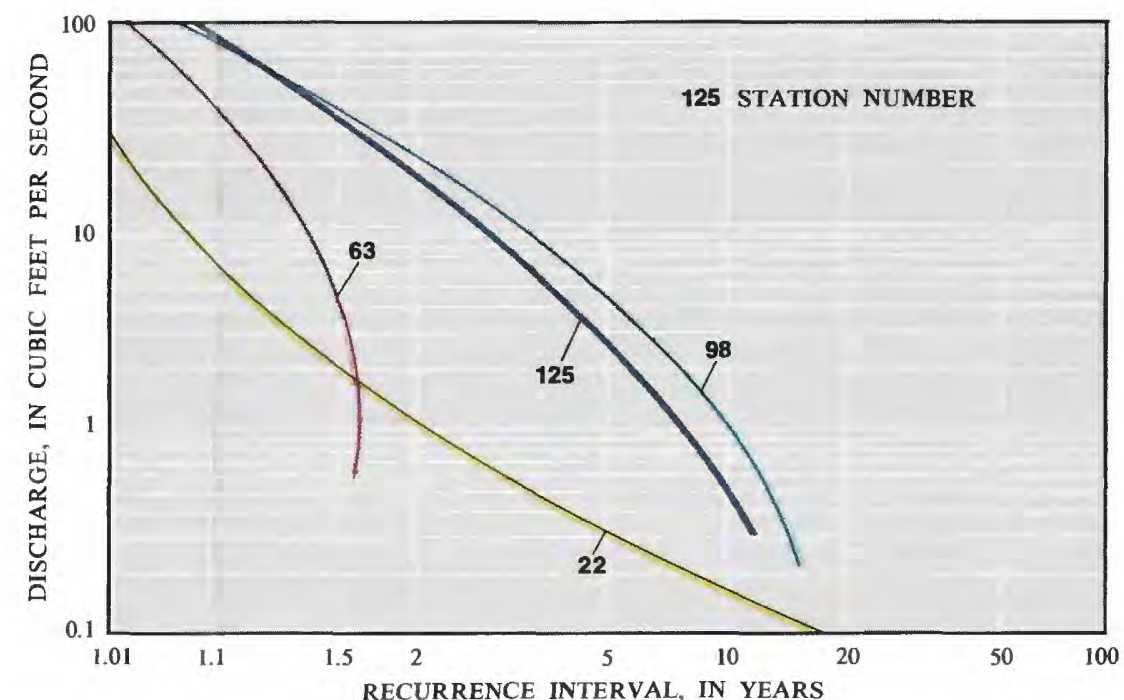

Figure 6.3-1 Seven-day low flow frequency curves for stations on the mainstem of the Powder River.

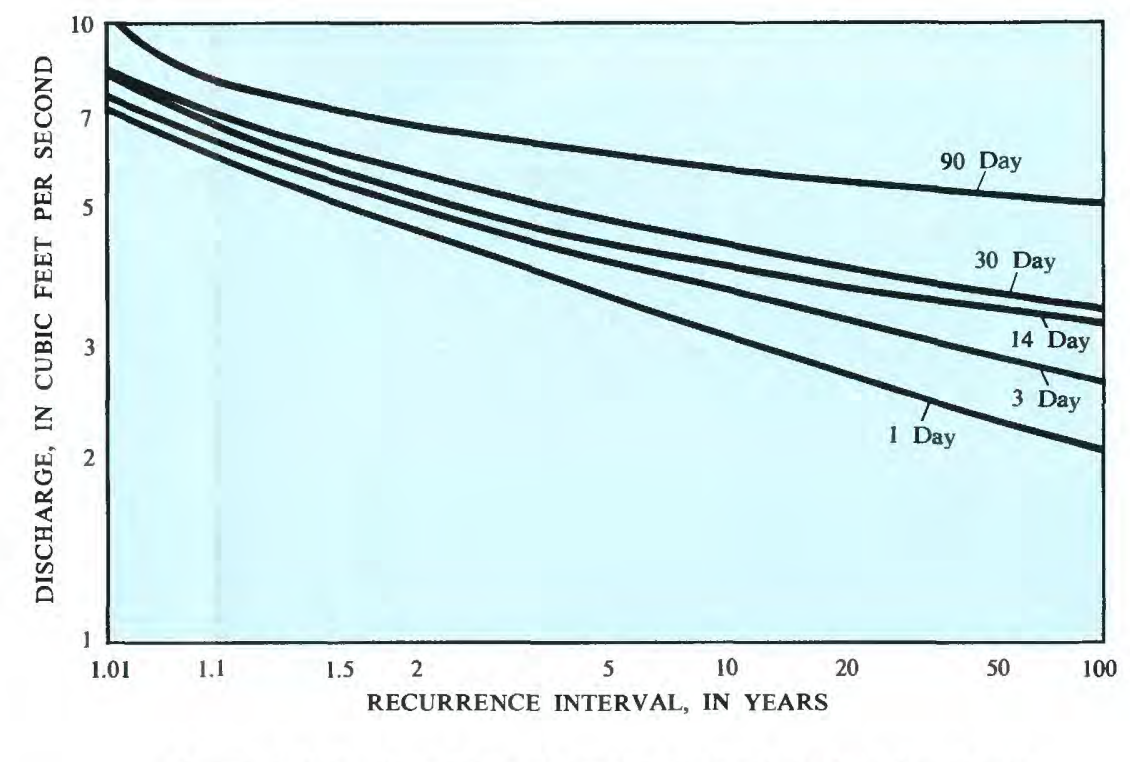

Figure 6.3-2 Low-Flow characteristics of station 81, North Piney Creek near Story, Wyoming. 


\title{
6.0 SURFACE-WATER QUANTITY--Continued
}

6.4 Floods

6.4.1 Occurrence

\section{Climatic Factors Determine Flood Flows}

\author{
Rapid spring snowmelt in the mountains and intense summer thunderstorms in the \\ plains cause most of the floods in the area.
}

Mountain streams flood mainly in spring or early summer. The magnitude of the flood depends on the volume and water content of snow accumulated during the preceding winter, the rate of increase in air temperature, and the quantity of spring rain. A gentle, warming trend in the spring causes a prolonged runoff, with stream channels full, but seldom overflowing. A sudden, unseasonably warm spell, however, with temperatures at night near or above freezing, can cause a short-duration runoff of much greater magnitude. Extremely large flows result when there is a combination of deep snowpack, warm air, and rain.

Plains streams may flood when accumulated snow is melted during a winter or spring thaw; spring rains and summer thunderstorms also may cause floods. Occasional intense thunderstorms in spring, summer, or fall produce the largest floods. Such storms typically pass over only part of a drainage area, but the magnitude of the floods, particularly in small streams, can be locally severe.

Significant floods occur somewhere in Area 50 nearly every year. It is rare to have severe flooding simultaneously on all major streams in the area. However, such flooding resulted from intense, areawide rainfall, preceded by greater than average runoff due to snowmelt and greater than average precipitation in May 1978 (Parrett and others, 1978; Parrett and others, 1984). The floods of May 1978 on the smaller drainage basins generally were not exceptionally large, but the cumulative effect produced floods that were the highest of record for many stations on the Powder, Cheyenne, and Belle Fourche Rivers (fig. 6.4.1-1).

The term "flood" has many definitions, most of which refer to flows greater than some base levelbankful flow, for example. For statistical purposes, the annual maximum flow, or peak discharge, is a flood, whether or not the water overflowed the stream banks. A comparison of the seasonal distribution of annual peak discharges on mountain and plains streams is shown in figure 6.4.1-2.

The flood hydrographs in figure 6.4.1-3 illustrate the differences in runoff characteristics of mountain and plains streams. The hydrograph for the mountain stream shows a gradual increase in daily discharge, followed by a gradual decrease. Daytime thawing and nighttime freezing of snowpack commonly superimpose diurnal variations on the general trend. The hydrograph for the plains stream (a large, ephemeral stream) shows more rapid increase and decrease in flow and a shorter duration of flow. Floods caused by thunderstorms on small, ephemeral streams usually peak quickly and last from a few hours to a few days. Practically all existing or planned coal mines in the area are in the plains areas.

In general, the relative magnitude of floods varies inversely with drainage area: the larger the area, the smaller the proportion of the area affected by snowmelt, by local thunderstorms, or by the most intense precipitation of large storm systems. Unit 100-year floods were calculated to illustrate this relationship (fig. 6.4.1-4). The unit 100-year flood is calculated by dividing the 100-year flood ( 1 percent exceedance probability in any year) by the drainage area.

The potential for damage to structures by floods is greater in or near the mountains than on the plains. Mountain roads and bridges commonly need to be constructed in locations where occasional flooding is unavoidable. Most towns in the area are located in the plains, except for Buffalo, which is near the base of the mountains. Towns commonly are established on or near a stream, in order to have an easily accessible water supply. Compared with the other towns the City of Gillette is a relatively large population center. Located near the head of a minor plains stream, some parts of Gillette are flooded by occasional fast-melting snow or by intense thunderstorms. Much of the flooding is caused by local drainage limitations. Elsewhere in the plains area, flash flooding generally causes loss of livestock and destruction of stock ponds; severe flooding may wash out roads and bridges or damage farmlands and pastures by erosion or by deposition of sediments. Flood damage in the plains areas sometimes is increased because of backwater and inundation caused by long fills used for approaches to bridges. 


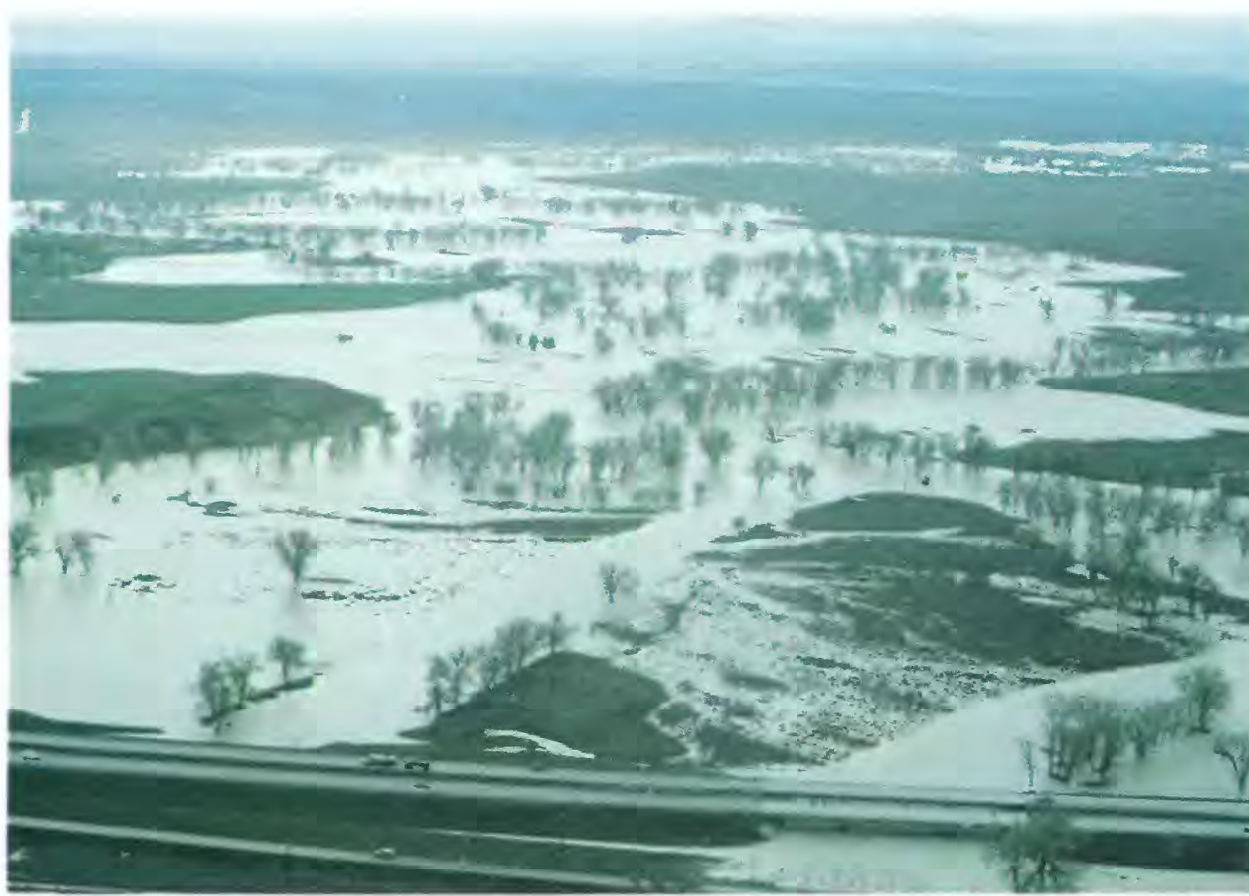

Figure 6.4.1-1 Flood of May 1978, Belle Fourche River near Moorcroft, Wyoming.

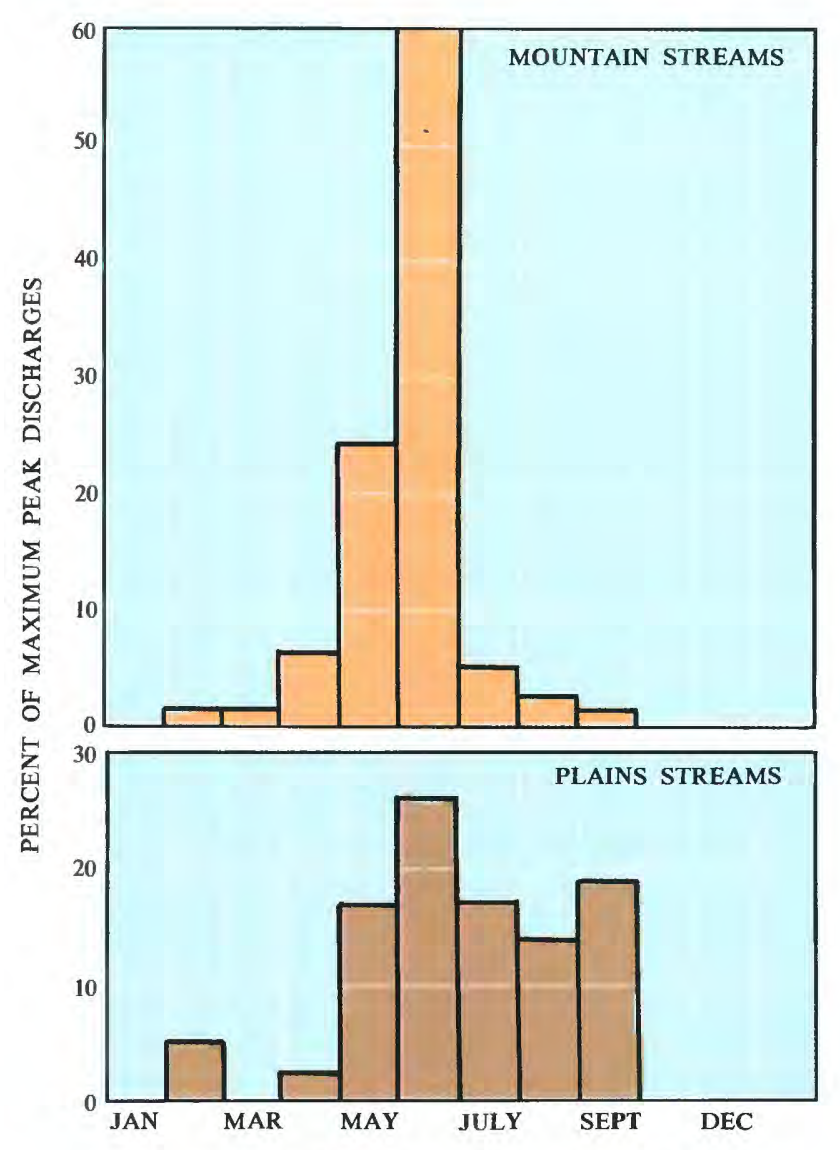
Figure 6.4.1-2 Seasonal occurrence of annual
peak flows (after Lowham, 1976).
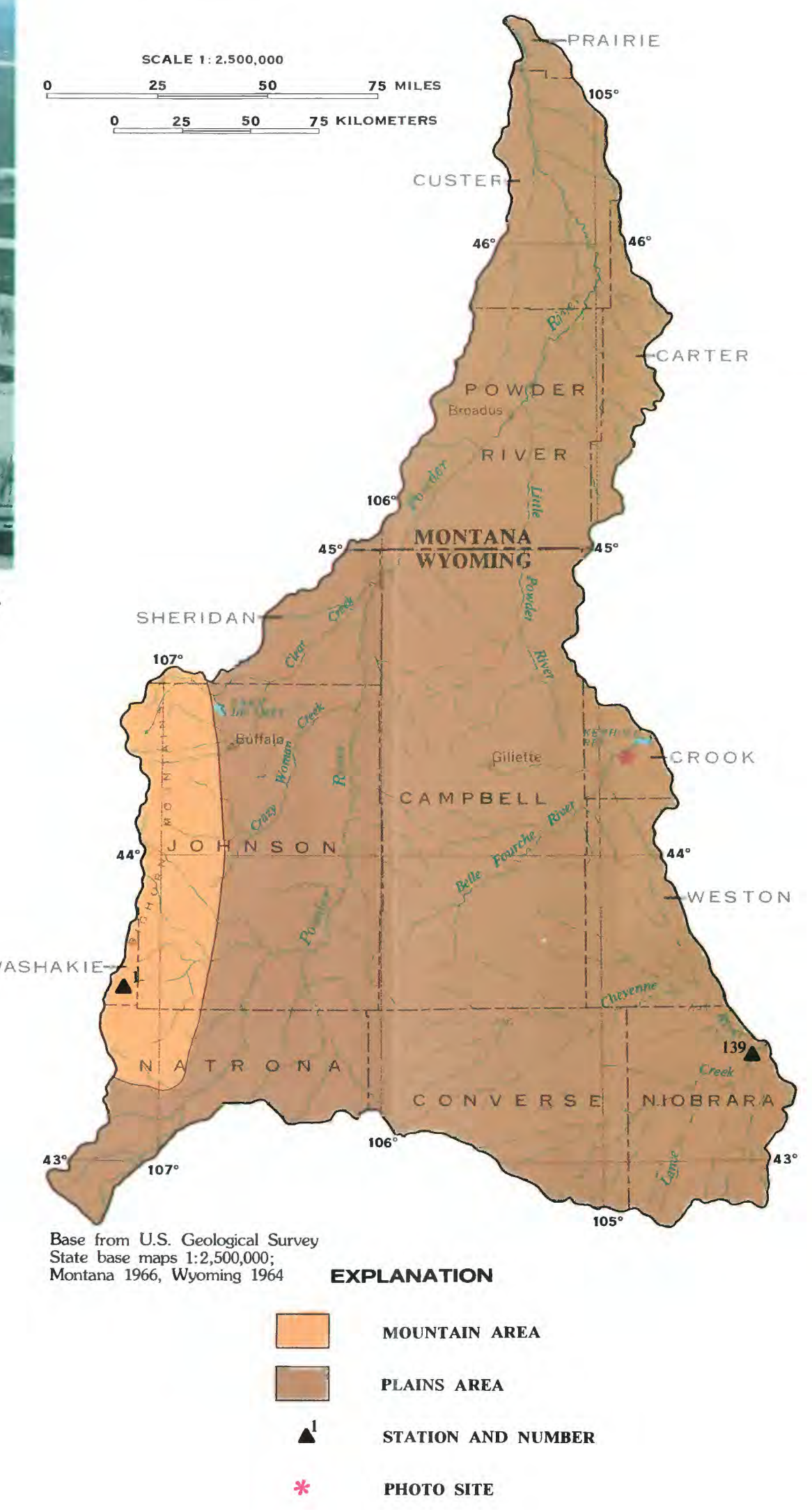

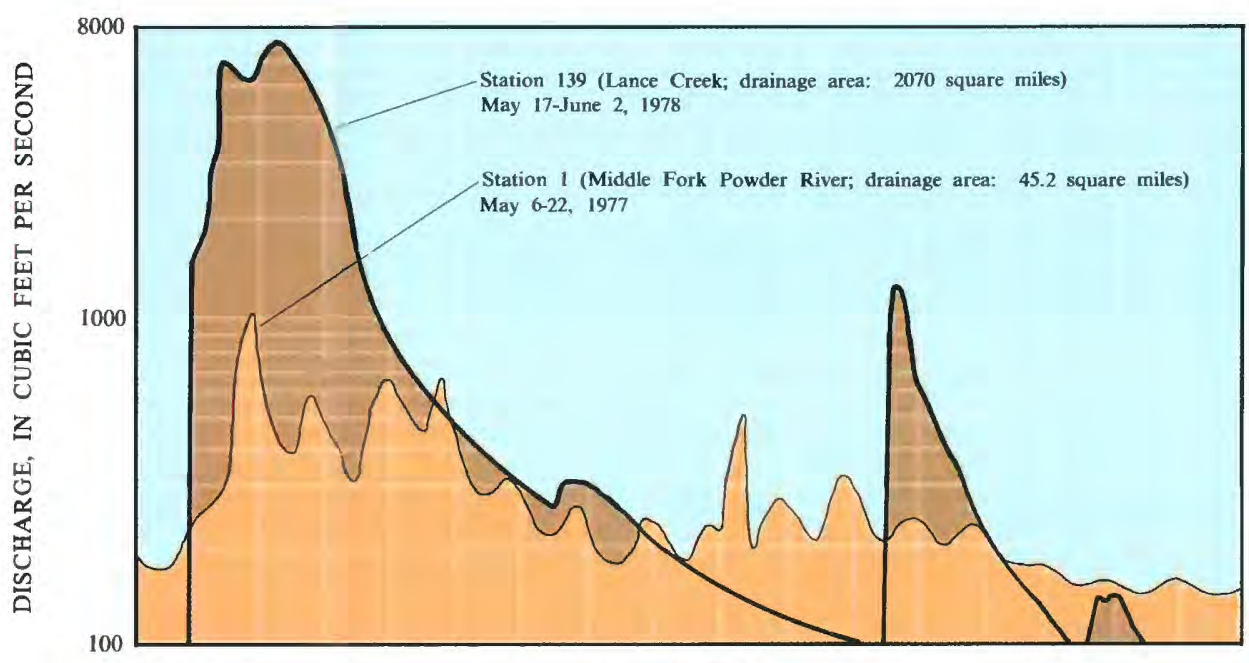

TIME, IN DAYS Figure 6.4.1-3 Flood hydrographs for a mountain
stream (station 1) and a plains stream (station 139)

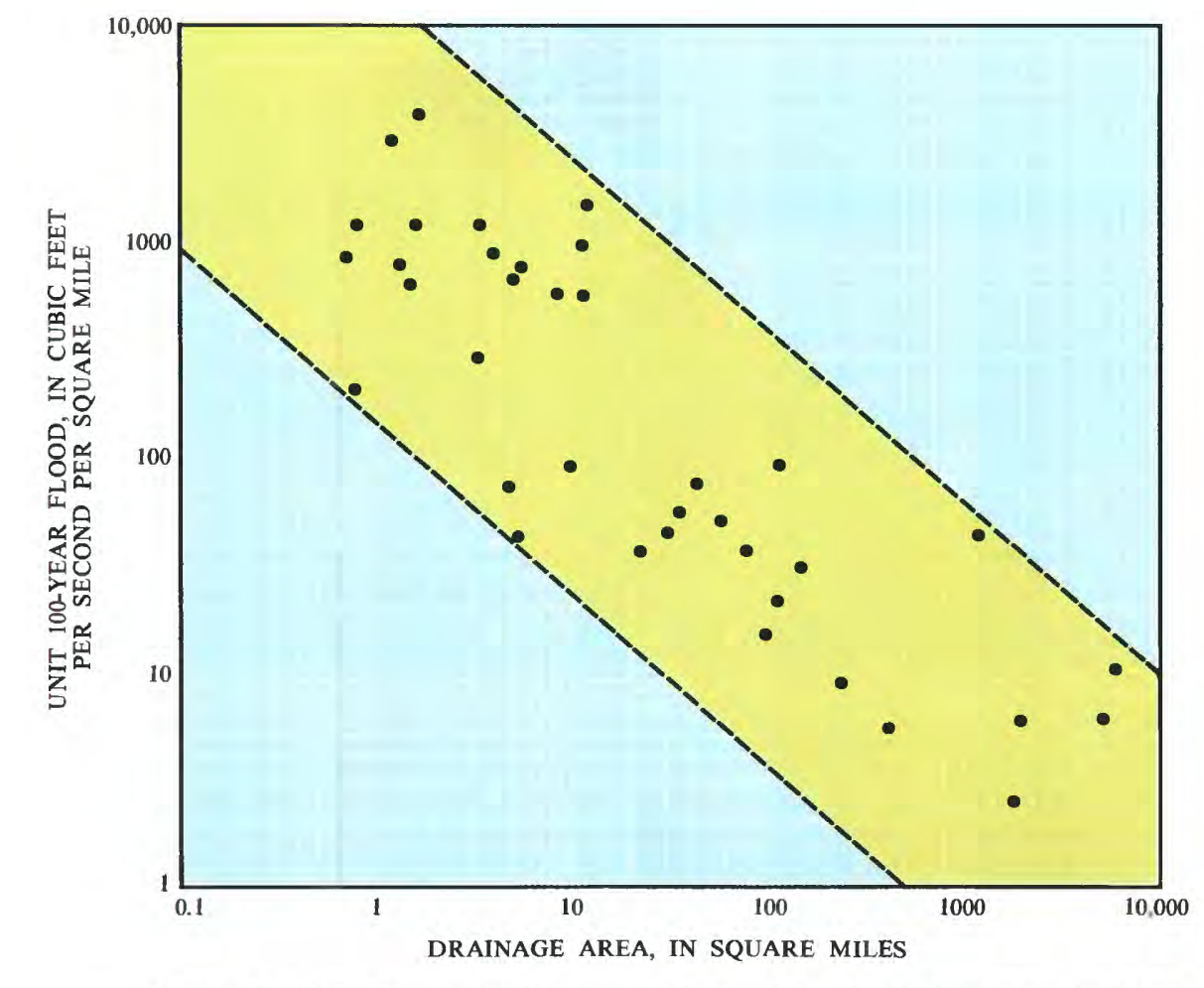

Figure 6.4.1-4 Generalized inverse relationship of relative magnitude of floods to drainage area for 37 stations in Area 50 . Stations for both
mountain and plains streams, perennial and ephemeral, are included. 


\title{
6.0 SURFACE-WATER OUANTITY--Continued \\ 6.4 Floods--Continued \\ 6.4.2 Peak-Flow Frequency
}

\section{0-Year Peak Discharges Can be Estimated}

\author{
Values of the 100-year flood are available from flood-frequency data for \\ 37 stations; graphs based on regionalized data may be used to estimate \\ the 100-year flood on mountain and plains streams.
}

Thirty-seven streamflow stations in Area 50 have discharge records of sufficient length to determine the 100-year peak discharge, or 100-year flood. The station numbers, drainage areas, and discharges are listed in table 6.4.2-1. A 100-year flood is defined as the annual maximum instantaneous (peak) discharge that will be equaled or exceeded once in 100 years, on the average. Another way of expressing it is the discharge that has a 1-percent chance of being equaled or exceeded in any given year. Floods of other frequencies, such as 10-year, 25-year, and so forth, are occasionally of interest; however, because most regulations concerning the effect of flooding are based on the 100-year flood, this discussion is limited to 100-year floods.

Equations or graphs for predicting the magnitude of the 100-year flood at ungaged sites are developed by regression techniques. Frequency curves for individual streamflow stations are first developed using the record of annual-maximum peak discharges at the stations. The methods used by the U.S. Geological Survey are those published by the U.S. Water Resources Council (1981). Values of discharge for the 100-year flood obtained from sufficiently long records at streamflow stations are used as the dependent variable in the regression analysis. Various basin and climatic characteristics are used as independent variables.

The graphs in figure 6.4.2-1 may be used to estimate the 100-year flood at ungaged sites in areas of corresponding color on the map. The boundaries shown on the map were modified from those developed by Lowham (1976). Somewhat more accurate estimates for sites in Montana may be obtained by using the equations developed by Parrett and Omang (1981), because they found that other independent variables, in addition to drainage area, improved the accuracy of the estimating equations. Hydrologists presently (1983) are revising the analyses for Wyoming, based on additional data obtained since the report by Lowham (1976) was prepared.

When an estimate of the 100 -year flood is needed for a basin encompassing more than one colored area on the map, an area-weighted average discharge needs to be used. This is done by: (1) Obtaining the discharge from each applicable graph, using the total drainage area; (2) multiplying each discharge by the ratio of the drainage area within the corresponding colored area to the total drainage area; and (3) obtaining the sum of the values in step 2 .

For some purposes estimates of flood discharge for frequencies other than 100-year are required. Estimates of the 10-year and 25-year floods, for example, may be required for the design of diversion ditches. The reports by Lowham (1976) and Parrett and Omang (1981) contain graphs and equations for estimating floods of selected frequencies.

A special method applicable only to ephemeral streams with drainage areas less than 11 square miles was developed by Craig and Rankl (1978). The method is time-consuming, but is considered to be more accurate than the graphs in figure 6.4.2-1. Besides drainage area, three additional basin characteristics first need to be measured on topographic maps:

1. Basin slope, in feet per mile. Obtained by measuring the length, in miles, of all contours within the drainage boundary (100-foot intervals usually suffice); multiplying by the contour interval, in feet; and dividing by the drainage area, in square miles.

2. Maximum relief, in feet. The difference in altitude between the channel at the site of interest and the highest point in the basin.

3. Channel slope, in feet per mile. Determined from altitudes at points 10 and 85 percent of the distance along the channel from the site of interest to the drainage-basin divide.

Once the four independent variables have been determined, the nomograph in figure 6.4.2-2 can be used to estimate the 100-year peak discharge. The arrows, starting with drainage area at the bottom of the graph, indicate the sequence to follow. 

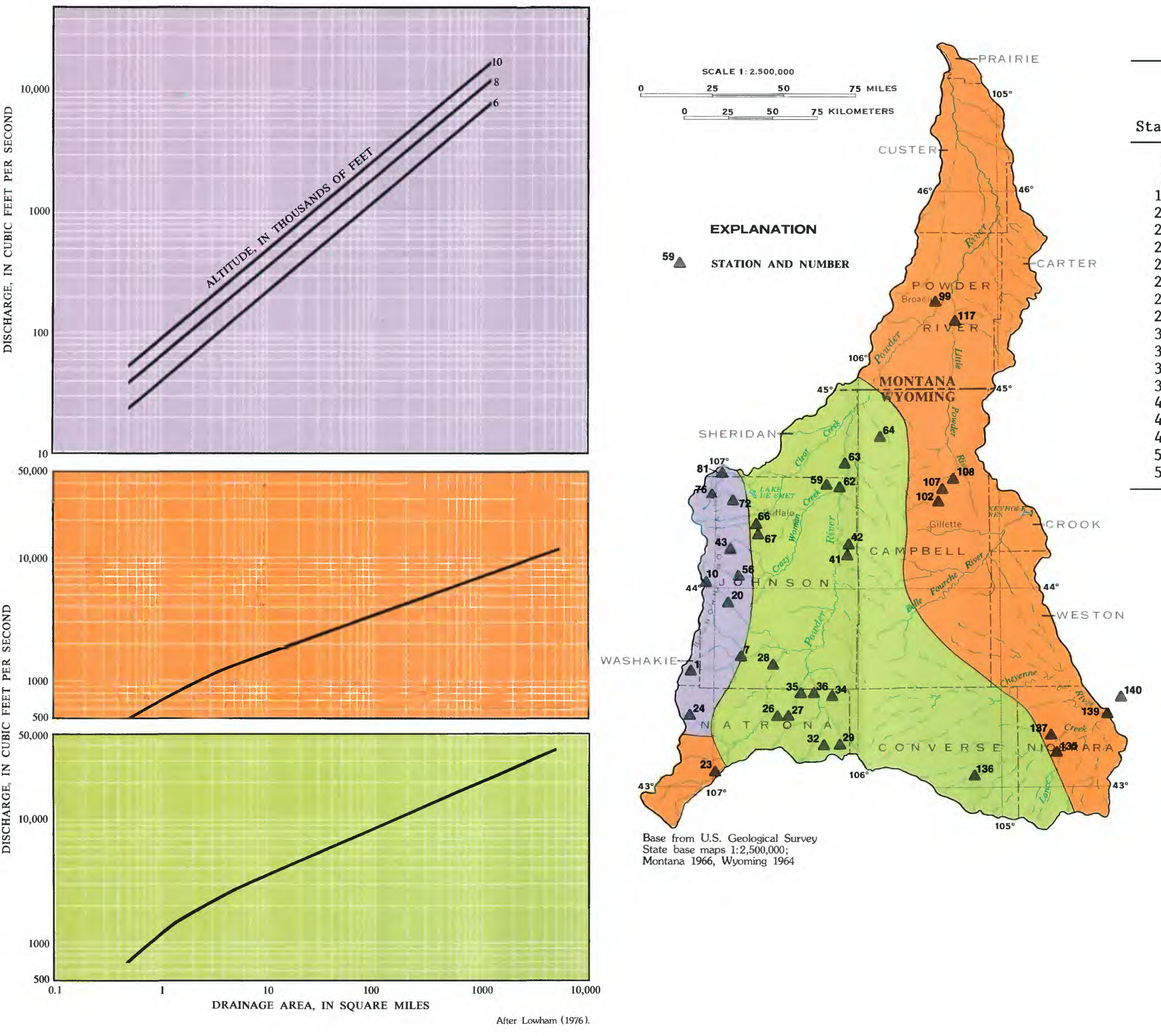

Figure 6.4.2-1 Relation of 100-year flood to drainage area for areas of corresponding color on map.
Table 6.4.2-1 100-year floods $\left(\mathbf{P}_{100)}\right.$ for selected stations.

\begin{tabular}{|c|c|c|c|c|c|}
\hline Station & $\begin{array}{c}\text { Drainage } \\
\text { area } \\
\text { (square } \\
\text { miles) }\end{array}$ & $\begin{array}{c}\mathrm{P}_{100} \\
\text { (cubic feet } \\
\text { per second) }\end{array}$ & Station & $\begin{array}{c}\text { Drainage } \\
\text { area } \\
\text { (square } \\
\text { miles) }\end{array}$ & $\begin{array}{l}\mathrm{P}_{100} \\
\text { (cubic feet } \\
\text { per second) }\end{array}$ \\
\hline 1 & 45.2 & 3,510 & 62 & 1.64 & 7,750 \\
\hline 7 & 450 & 2,190 & 63 & 6,050 & 60,400 \\
\hline 10 & 24.5 & 865 & 64 & 3.98 & 4,100 \\
\hline 20 & 106 & 1,520 & 66 & 120 & 2,390 \\
\hline 23 & 262 & 2,160 & 67 & 10.8 & 18,100 \\
\hline 24 & 5.53 & 215 & 72 & 60.0 & 3,030 \\
\hline 26 & 1.53 & 1,130 & 76 & 33.6 & 1,430 \\
\hline 27 & 1.34 & 1,230 & 81 & 36.8 & 1,990 \\
\hline 28 & 1,150 & 52,100 & 99 & 10.2 & 887 \\
\hline 29 & 8.29 & 5,470 & 102 & .81 & 163 \\
\hline 32 & 5.44 & 4,840 & 107 & 3.45 & 1,070 \\
\hline 34 & 11.4 & 7,520 & 108 & .72 & 697 \\
\hline 35 & .80 & 1,130 & 117 & 1,970 & 4,220 \\
\hline 36 & 1.60 & 2,300 & 135 & 1.20 & 4,530 \\
\hline 41 & 10.8 & 12,500 & 136 & 112 & 10,200 \\
\hline 42 & 151 & 4,490 & 137 & 5.10 & 4,030 \\
\hline 43 & 5.08 & 359 & 139 & 2,070 & 11,000 \\
\hline 56 & 82.7 & 3,050 & 140 & 5,270 & 28,900 \\
\hline 59 & 3.32 & 4,790 & & & \\
\hline
\end{tabular}

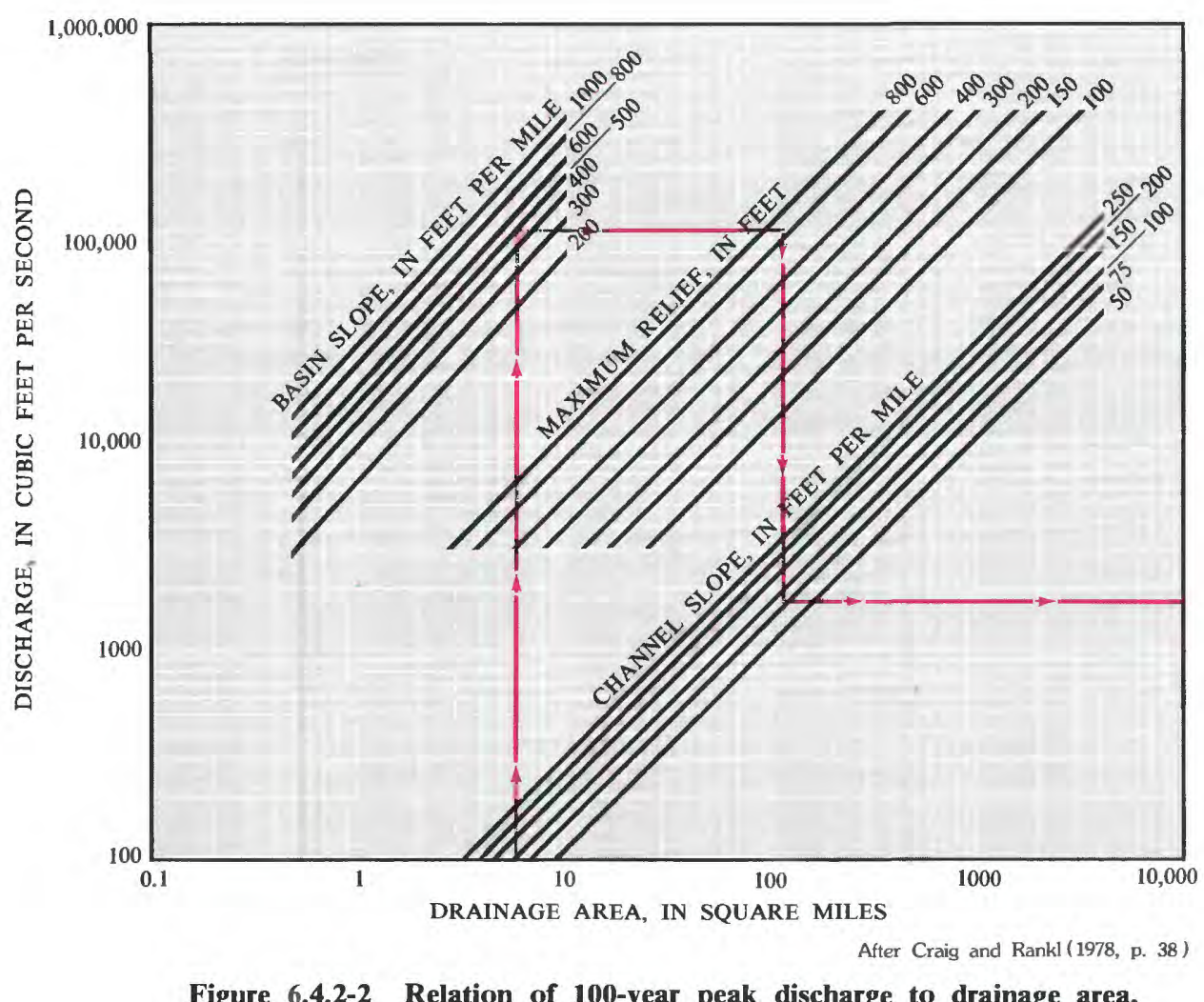

Figure 6.4.2-2 Relation of 100-year peak discharge to drainage area, basin slope, maximum relief, and channel slop.
than 11 square miles.

6.0 SURFACE-WATER QUANTITY--Continued 6.4 Floods--Continued
6.4.2 Peak-Flow Frequency 


\title{
6.0 SURFACE-WATER QUANTITY--Continued \\ 6.4 Floods--Continued \\ 6.4.3 Hydrographs--Small Streams
}

\section{Hydrographs Available for Small Ephemeral Streams}

\author{
Rainfall-runoff data are available for six ephemeral streams with drainage \\ areas smaller than 10 square miles; also, a method is available for \\ preparing synthetic hydrographs for specified peak discharges.
}

Real or synthetic hydrographs of reliable accuracy for small streams commonly are needed in planning and design. Although such data are scarce, both types of hydrographs are available for the Wyoming part of Area 50. The hydrographs are a product of a study of runoff in small ephemeral streams in Wyoming (Craig and Rankl, 1978). Hydrograph data collected in the study by Craig and Rankl were compiled by Rankl and Barker (1977). Their report includes a tabulation of precipitation and discharge in 5-minute increments for 392 storms in 22 drainage basins. Six of the basins are in Area 50 (see fig. 6.4.3-1):

\begin{tabular}{rcc}
$\begin{array}{c}\text { Station } \\
\text { number }\end{array}$ & $\begin{array}{c}\text { Drainage area } \\
\text { (square miles) }\end{array}$ & $\begin{array}{c}\text { Number of } \\
\text { hydrographs }\end{array}$ \\
26 & 1.53 & 21 \\
27 & 1.34 & 21 \\
32 & 5.44 & 17 \\
35 & .80 & 24 \\
59 & 3.32 & 12 \\
137 & 5.1 & 25 \\
\hline
\end{tabular}

Craig and Rankl (1978) also developed a dimensionless hydrograph that defines the characteristic shape of flood hydrographs for small ephemeral streams in Wyoming. The hydrograph is a composite of 298 real hydrographs for 28 small basins. Hydrographs synthesized from the dimensionless hydrograph were compared with corresponding real hydrographs for numerous other small basins in Wyoming, New Mexico, and Arizona. The comparisons were excellent in most instances. Although the dimensionless hydrograph was not tested with data for Montana streams, it may be used to synthesize hydrographs for streams in the Montana part of Area 50. The dimensionless hydrograph is shown in figure 6.4.3-2; the values of the discharge and time factors that form the hydrograph are listed in table 6.4.3-1.

The construction of a synthetic hydrograph requires estimates of two variables: peak discharge and a corresponding flow volume. The correlation of these two variables seems to be better for smaller streams than for larger streams. The volumedischarge relation developed by Craig and Rankl (1978, p. 45-49) has a standard error of estimate of 55 percent, based on 105 hydrographs. The graph is shown in figure 6.4.3-3. If peak discharge is specified, the corresponding volume can be determined. Conversely, a peak discharge corresponding to a specified volume also may be determined from the graph. The frequency, or exceedance probability, of the dependent variable is not related to that of the independent variable. For example, if 1,000 cubic feet per second is the 100-year peak discharge (1 percent exceedance probability), the corresponding volume, 56 acre-feet (fig. 6.4.3-3) is not the 100-year volume. It simply is the volume associated with the 100-year peak discharge.

To determine plotting points (discharge, in cubic feet per second, and time, in minutes), multiply each value of the discharge factor (table 6.4.3-1) by the peak discharge, $Q$, and multiply each value of the corresponding time factor by the ratio of volume to discharge, $V / Q$. Construct the hydrograph by plotting ard connecting the points as shown in the example (fig. 6.4.3-4).

The actual distribution of flow during a specified time, and hence the shape of the resulting hydrograph, depends on the distribution of precipitation on the basin and on the variation in the duration and rate of precipitation. Real hydrographs can have two or more peaks and can have runoff durations lasting much longer than those indicated by the synthetic hydrographs. For a given peak discharge and volume, however, Craig and Rankl (1978, p. 59) demonstrated that the fast-rising single-peak hydrograph is the most important type for evaluating possible backwater ponding at culvert sites. Although the experiments of Craig and Rankl were limited to the effects of culverts, the conclusion about hydrograph shape can apply to the hydraulic design of any structure--sediment ponds for example. 


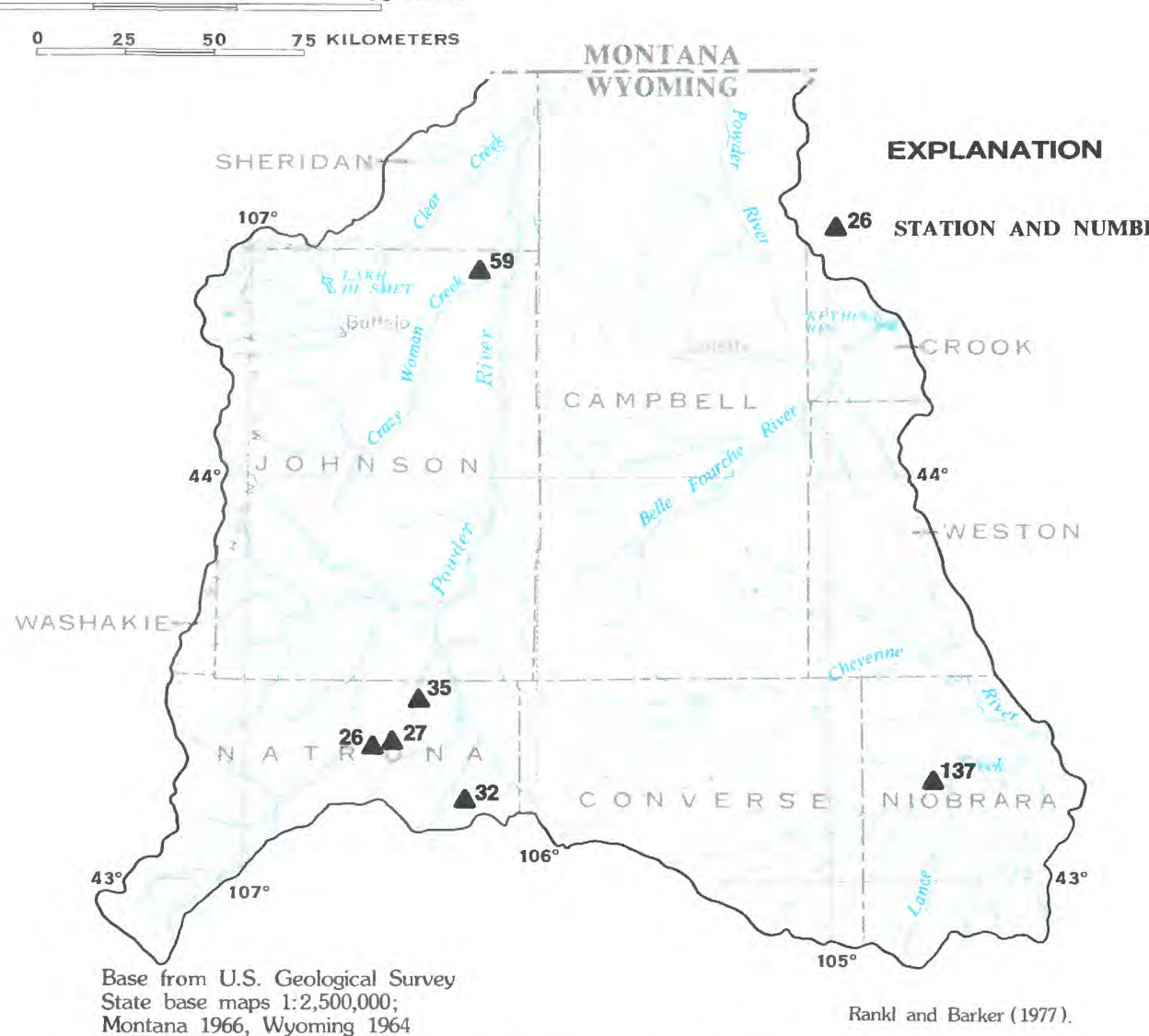

Figure 6.4.3-1 Location of sites on small

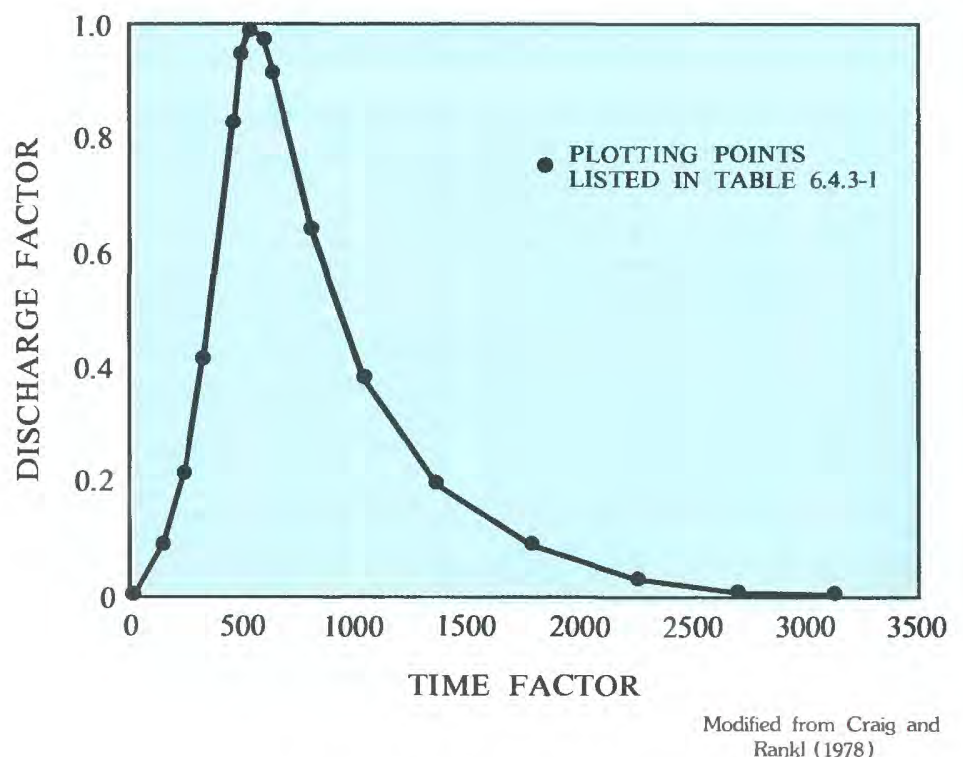

Figure 6.4.3-2 Dimensionless
Table 6.4.3-1 Factors for calculating Discharge

Discharge factor

\begin{tabular}{cc}
\hline 0 & factor \\
0.093 & 0 \\
.217 & 134.7 \\
.417 & 224.5 \\
.817 & 314.3 \\
.950 & 449.0 \\
1.000 & 493.5 \\
.983 & 538.8 \\
.917 & 583.7 \\
.633 & 628.6 \\
.383 & 808.2 \\
.200 & 1,033 \\
.087 & 1,347 \\
.033 & 1,796 \\
.008 & 2,245 \\
0 & 2,694 \\
\hline
\end{tabular}

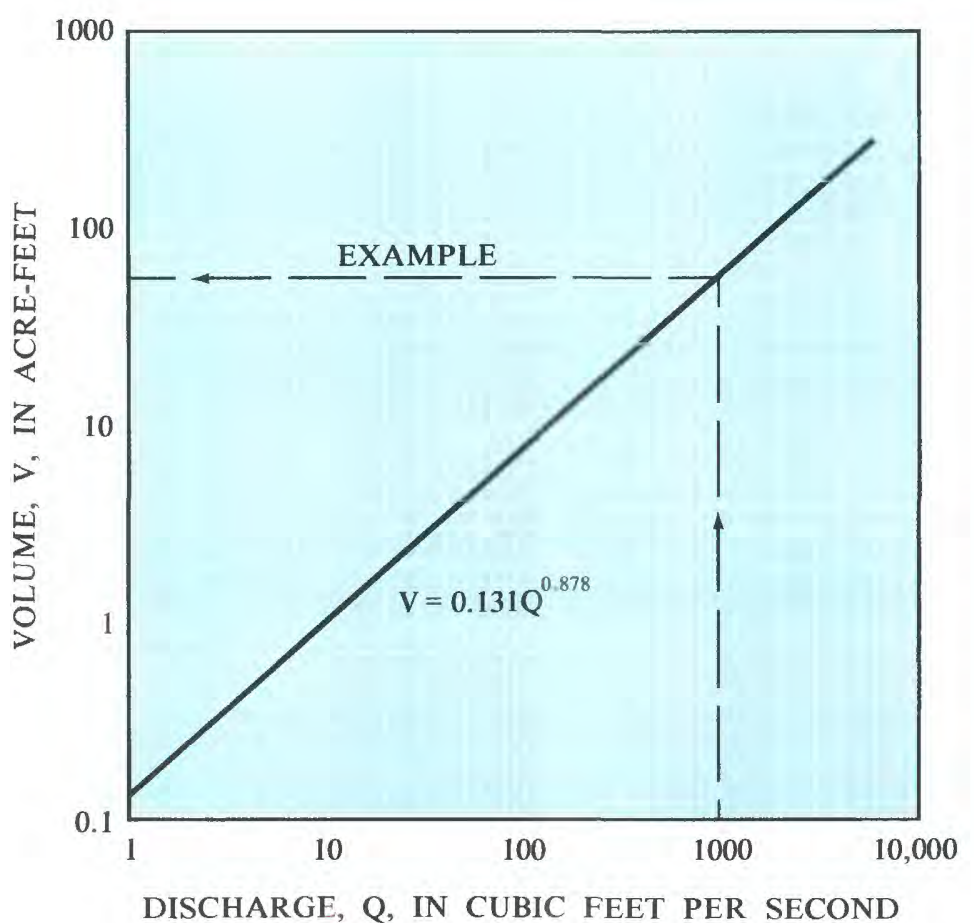

After Crais and Rankl (1978).

Figure 6.4.3-3 Relation of flood volume to peak discharge.

\section{EXAMPLE:}

CONSTRUCTION OF A SYNTHETIC HYDROGRAPH FOR A FLOOD

Corresponding volume (V) from Figure 6.4.3-3 $=56$ acre-feet

2. Ratio $(\mathrm{V} / \mathrm{Q})=0.056$

3. Hydrograph plotting points, using factors in table 6.4.3-1:

\begin{tabular}{cc}
\hline $\begin{array}{c}\text { Discharge, in cubic feet per second } \\
\text { (each discharge factor multiplied by } \text { ) }\end{array}$ & $\begin{array}{c}\text { Time, in minutes } \\
\text { (each time factor multiplied by } \mathrm{v} / \mathrm{Q} \text { ) }\end{array}$ \\
\hline 0 & 0 \\
93 & 8 \\
217 & 13 \\
417 & 18 \\
817 & 25 \\
950 & 28 \\
1000 & 30 \\
983 & 33 \\
917 & 35 \\
633 & 45 \\
383 & 58 \\
200 & 75 \\
87 & 101 \\
33 & 126 \\
8 & 151 \\
0 & 176 \\
\hline
\end{tabular}

4. Plotted hydrograph:

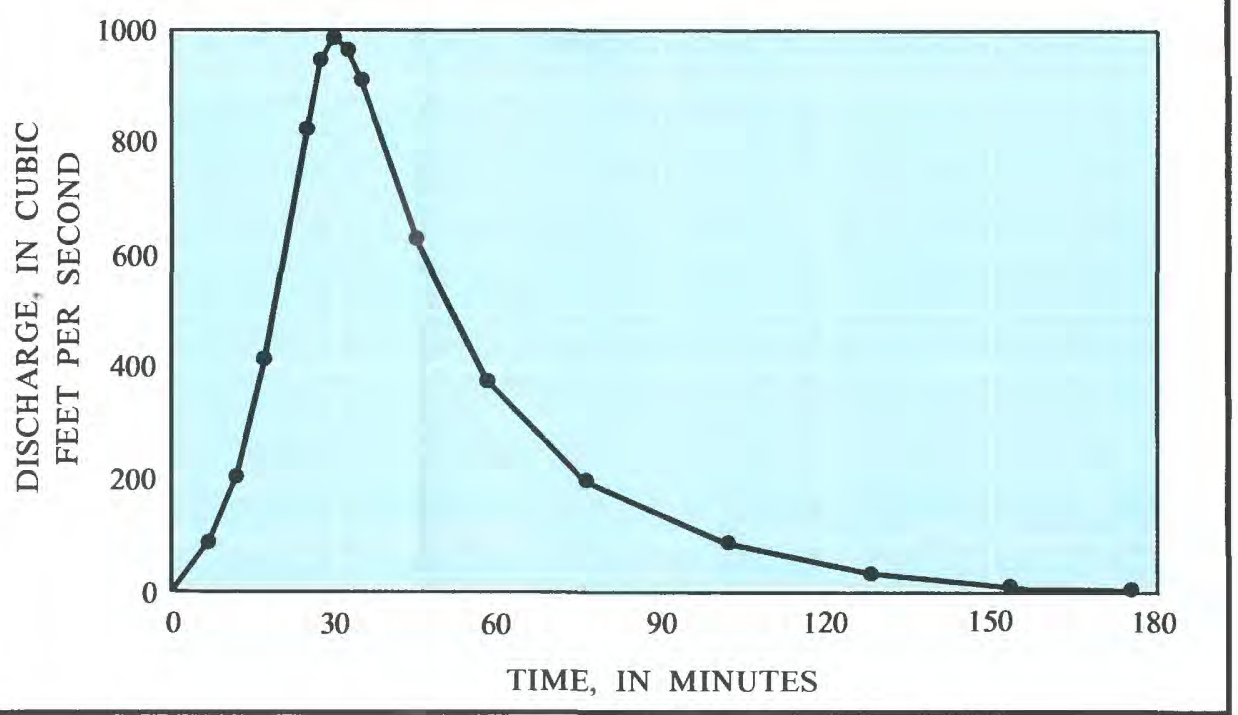

Figure 6.4.3-4 Example of

construction of a synthetic hydrograph.

6.0 SURFACE-WATER QUANTITY--Continued

6.4 Floods--Continued
6.4.3 Hydrographs-Small Streams 


\subsection{SURFACE-WATER QUANTITY--Continued \\ 6.4 Floods--Continued \\ 6.4.4 Flood-Prone Area Maps}

\section{Maps Available for Flood-Prone Areas}

\section{U.S. Geological Survey flood-prone area maps are available for the main stem of the Powder River and the City of Buffalo; National Flood Insurance Program maps also are available for a few communities and counties.}

Flood-prone area maps have been prepared by the U.S. Geological Survey for 43 topographic quadrangles (scale, $1: 24,000$ ) in Area 50 (table 6.4.4-1 and fig. 6.4.4-1). In accordance with the recommendations contained in House Document 465, 89th Congress, hydrologists used information about depth of flooding at streamflow stations and other sites to delineate the boundaries of areas of potential flooding. The National Flood Insurance Act of 1968 required the Federal Insurance Administration (FIA) to identify areas subject to inundation by the 100 -year flood (1-percent exceedance probability in any year); therefore, the Geological Survey delineated the boundaries of the 100-year flood on the maps. Because the nationwide task was to be accomplished in a short time, hydrologists used simplified procedures to extrapolate data from sites where flood depths were known to stream reaches where data about flood depths were lacking.

The flood-prone area maps prepared by the Geological Survey are not flood-insurance maps, but are intended to alert the public to areas of potential flooding. Black-and-white copies of the maps are available free of charge as follows:

\author{
Wyoming \\ District Chief, WRD \\ U.S. Geological Survey \\ P. O. Box 1125 \\ Cheyenne, WY 82003 \\ Telephone: (307) 772-2153 \\ FTS 328-2153 \\ Montana \\ Montana College of Mineral \\ Science and Technology \\ Butte, MT 59701
}

Telephone: (406) 496-4166

Under the National Flood Insurance Program, the FIA has prepared maps that are official documents for flood-insurance and other purposes, such as determining whether a proposed action by a Federal agency will occur in a flood-hazard area. Some of the FIA maps are based directly on Geological Survey flood-prone area maps; others are based on more detailed hydrologic investigations. FIA maps are available for the communities and counties listed below; the town of Edgerton, Wyo. is not presently (1983) participating in the National Flood Insurance Program.

\begin{tabular}{cc}
\hline Communities & $\begin{array}{c}\text { Counties } \\
\text { (Unincorporated } \\
\text { areas only) }\end{array}$ \\
Buffalo, Wyo. & Campbell (Wyo.) \\
Edgerton, Wyo. & Converse (Wyo.) \\
Gillette, Wyo. & Natrona (Wyo.) \\
Moorcraft, Wyo. & Sheridan (Wyo.) \\
Kaycee, Wyo. & Custer (Mont.) \\
Broadus, Mont. & Powder River (Mont.) \\
\hline
\end{tabular}

Copies of FIA maps are available from:

Federal Emergency Management Agency National Flood Insurance Program P. O. Box 34294 Bethesda, MD 20034 Telephone (800) 638-6620 (toll free) (800) 492-6605 (toll free, Maryland only) (301) 897-5900 (Washington, D.C., metropolitan area) 


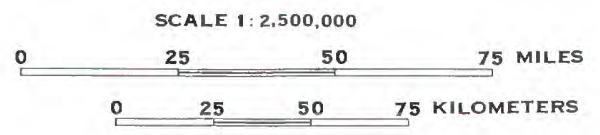

Table 6.4.4-1 List of U.S.

Geological Survey flood-prone area maps.

\begin{tabular}{|c|c|}
\hline $\begin{array}{l}\text { Map } \\
\text { no. }\end{array}$ & $\begin{array}{l}\text { Map } \\
\text { name }\end{array}$ \\
\hline & Wyoming \\
\hline 1 & Kaycee \\
\hline 2 & Kaycee NE \\
\hline 3 & Figure 8 Reservoir \\
\hline 4 & Sussex \\
\hline 5 & House Creek \\
\hline 6 & Soldier Creek \\
\hline 7 & Fort Reno \\
\hline 8 & Hoe Ranch \\
\hline 9 & Bowman Flat \\
\hline 10 & Juniper Draw \\
\hline 11 & $\begin{array}{l}\text { Laskie Draw (a part of Juniper } \\
\text { Draw map) }\end{array}$ \\
\hline 12 & Somerville Flats West \\
\hline 13 & $\begin{array}{l}\text { Somerville Flats East (a part of } \\
\text { Somerville Flats West map) }\end{array}$ \\
\hline 14 & Mitche11 Draw \\
\hline 15 & Livingston Draw \\
\hline 16 & Lariat \\
\hline 17 & Arvada \\
\hline 18 & Arvada NE \\
\hline 19 & Fawn Draw \\
\hline 20 & Cabin Creek SE \\
\hline 21 & Cabin Creek NE \\
\hline 22 & Black Draw \\
\hline \multirow[t]{2}{*}{23} & Buffalo \\
\hline & Montana \\
\hline 24 & Bradshaw Creek \\
\hline 25 & Moorhead \\
\hline 26 & Bloom Creek \\
\hline 27 & Huckins School \\
\hline 28 & Yarger Butte \\
\hline 29 & Lonesome Peak \\
\hline 30 & Eldon Mountain \\
\hline 31 & Broadus \\
\hline 32 & Monday Creek \\
\hline 33 & Hawkey Creek \\
\hline 34 & Cross S School \\
\hline 35 & Bear Jaw Creek \\
\hline 36 & Tepee Butte \\
\hline 37 & Mizpah \\
\hline 38 & Pennock Creek \\
\hline 39 & Locate SE \\
\hline 40 & Locate \\
\hline 41 & Spring Draw \\
\hline 42 & Zero \\
\hline 43 & Zero NE \\
\hline
\end{tabular}

EXPLANATION

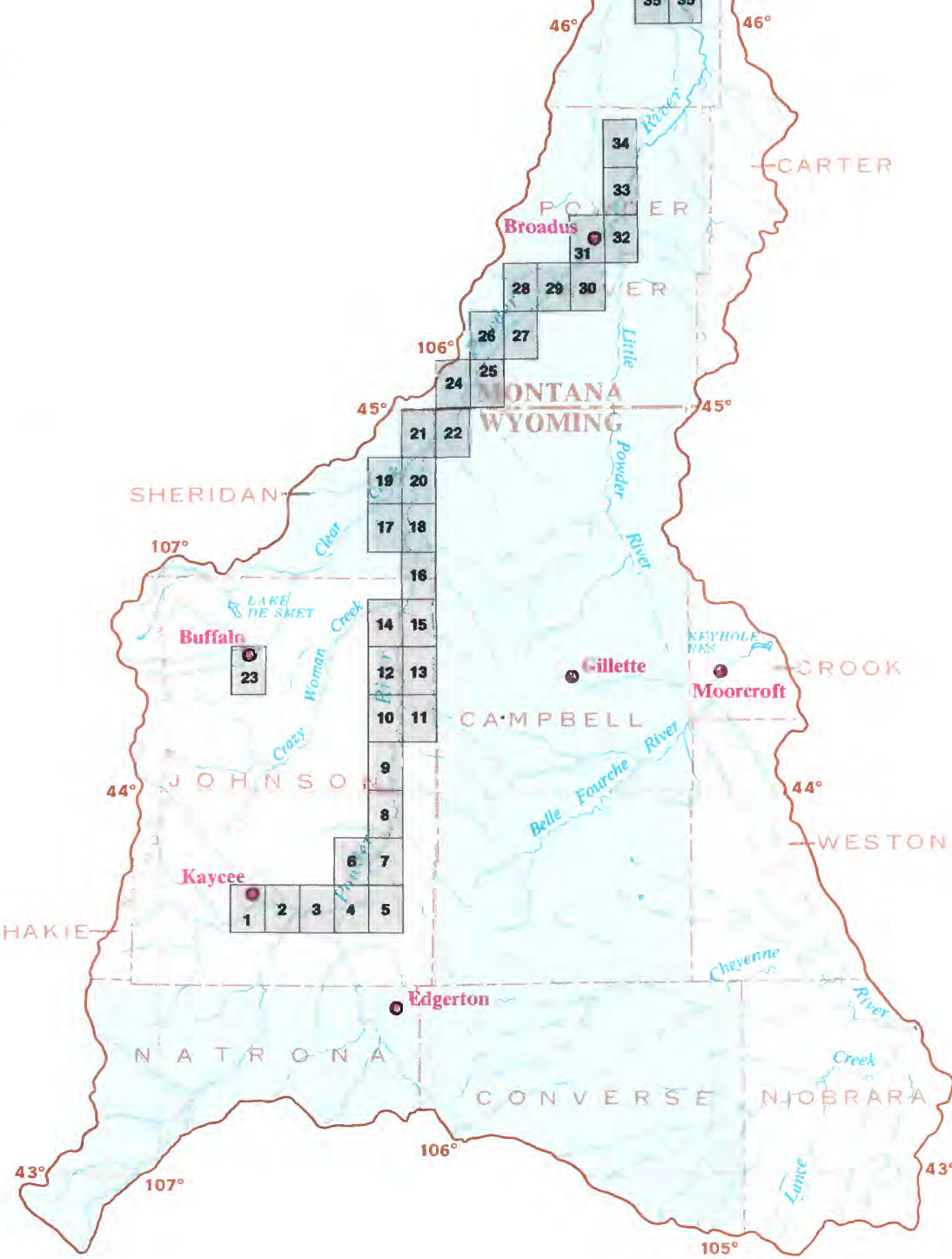

Base from U.S. Geological Survey State base maps 1:2,500,000; Montana 1966, Wyoming 1964

FEDERAL INSURANCE ADMINISTRATION MAP AVAILABLE FOR COMMUNITY INDICATED

FEDERAL INSURANCE

ADMINISTRATION MAP AVAILABLE FOR COUNTY

U.S. GEOLOGICAL SURVEY FLOOD-PRONE AREA MAP AVAILABLE-

Map number corresponds to numbers in Table 6.4.4-1

Figure 6.4.4-1 Location of Federal Insurance Administration maps and U.S. Geological Survey flood-prone area maps. 


\title{
6.0 SURFACE-WATER QUANTITY--Continued 6.5 Relationship to Ground Water
}

\section{Most Base Flow is from Local Ground-Water Systems}

\author{
Analysis of streamflow and water-level data indicates that discharge to \\ streams from local ground-water systems is greater than discharge from \\ a regional ground-water system.
}

\begin{abstract}
Coal-bearing formations underlie the alluvium from the mouth of the Powder River to a point upstream from Sussex, Wyo. (station 39). Water levels in coal-bearing formations indicate that the downstream reach of the river should gain flow, at least as far upstream as Arvada, Wyo. (station 63). However, long-term records show that flow decreases even during winter months in the Powder River from Sussex, Wyo., to Locate, Mont. (fig. 6.5-1). The change in flow was determined by subtracting the average daily discharge at an upstream station from the average daily discharge at a downstream station. There is no diversion of water for irrigation outside the valley.
\end{abstract}

Annual and seasonal trends or changes in streamflow generally are masked by flow variability; therefore, hydrographs of average daily discharge are used to show flow conditions for the period of record. The hydrographs make it possible to determine long-term averages of base flow, streamflow losses, and changes in base flow due to evapotranspiration.

Another technique to determine the presence or absence of ground-water contribution to streamflow is to examine the shapes of flow-duration curves. The flow-duration curve has been described by Searcy $(1959$, p. 1) as "a cumulative frequency curve that shows the percent of time during which specified discharges were equaled or exceeded in a given period." Searcy $(1959$, p. 22$)$ described the interpretation of the shapes of the flow-duration curves as follows: "A curve with a steep slope throughout denotes a highly variable stream whose flow is largely from direct runoff, whereas a curve with a flat slope reveals the presence of surface- or ground-water storage, which tends to equalize the flow." A change in slope of a flow-duration curve can provide as much or more information as the steepness or flatness of the slope. For example, a decrease in the slope in the lower part of the flow-duration curve may indicate a small quantity of ground-water discharge. An increase in slope indicates the depletion of surface- or ground-water storage.

Flow records of streams in the Powder River
Basin were analyzed using flow-duration curves and average-discharge hydrographs to determine the type of stream and the ground-water/surface-water interaction. The data in table 6.5-1 indicate that there is little base flow from ground water in streams originating in areas underlain by the Fox HillsWasatch sequence.

Flow-duration curves for Dead Horse Creek (station 42), the Little Powder River (station 117), and Black Thunder Creek (station 133) are shown in figure 6.5-2. The difference in flow for streams with base flow (station 117) and without base flow (stations 42 and 133) can be seen by comparing the flow-duration curves. Base flow in the nongrowing season was determined from the average-discharge hydrograph such as shown in figure 6.5-3 for the Little Powder River (station 117). The absence of measurable base flow in the Powder River and the presence of some base flow in the smaller streams in areas of coal-bearing formations indicate that discharge from the local ground-water systems is more important to base flow in streams than is a regional ground-water system.

The flow-duration curves (fig. 6.5-2) for North Fork Crazy Woman Creek (station 44) and Beaver Creek (station 6) show flow characteristics typical of granitic and limestone areas of the Bighorn Mountains. Granite stores and discharges less water than limestone; therefore, the duration curve for North Fork Crazy Woman Creek, which drains the granitic area, is steeper, indicating less base flow. Snow persists throughout the year in the higher parts of the Bighorn Mountains and contributes to the low flow of some streams. The flow-duration curve for Beaver Creek, which drains an area underlain by limestone, has a flatter slope, indicating more base flow. The streamflow across limestone rocks can vary significantly because of large sinks and springs. The Wyoming State Engineer's Office (1976, p. 95) reported a cumulative increase in flow of about 80 cubic feet per second in the principal streams crossing limestone on the east flank of the Bighorn Mountains in Wyoming. 


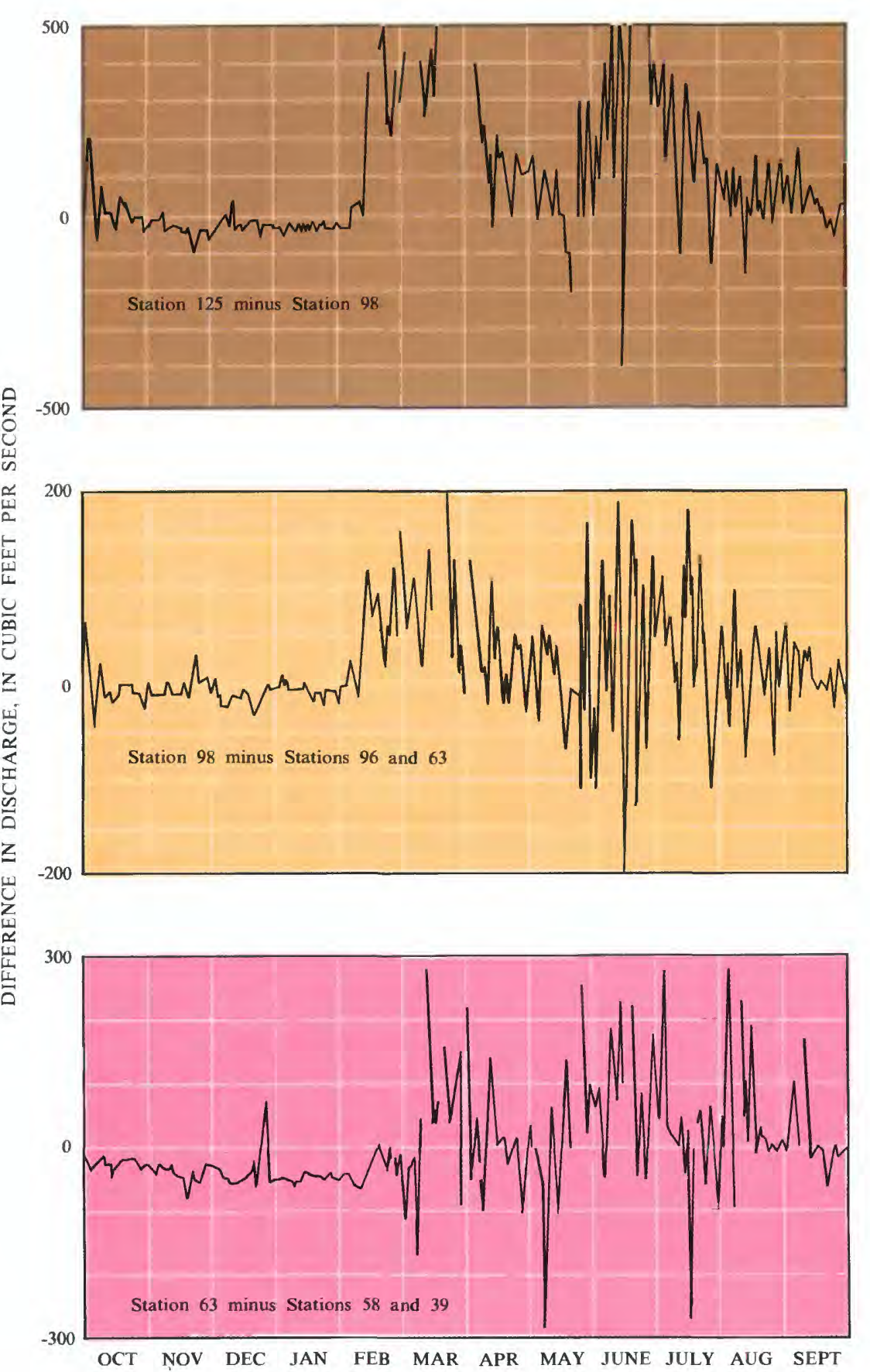

Figure 6.5-1 Differences in average discharge
for the indicated reaches of the Powder River.

Table 6.5-1 Summary of ground-water/surface-water relationships of

\begin{tabular}{ccccc}
\hline Station & $\begin{array}{c}\text { Brainage } \\
\text { area } \\
\text { (square miles) }\end{array}$ & $\begin{array}{c}\text { Base flow } \\
\text { during } \\
\text { nonground } \\
\text { seasong } \\
\text { water } \\
\text { numbicated }\end{array}$ & $\begin{array}{c}\text { (cubic feet } \\
\text { per second) }\end{array}$ & $\begin{array}{c}\text { Period } \\
\text { of } \\
\text { record }\end{array}$ \\
\hline 42 & 155 & Yes & 0 & $1971-77$ \\
112 & 1,230 & Yes & 1 & $1972-77$ \\
117 & 1,974 & Yes & 5 & $1957-72$ \\
133 & 535 & No & 0 & $1972-77$ \\
140 & 5,270 & No & 0 & $1948-77$ \\
150 & 1,670 & Yes & 0 & $1944-70$ \\
\hline
\end{tabular}
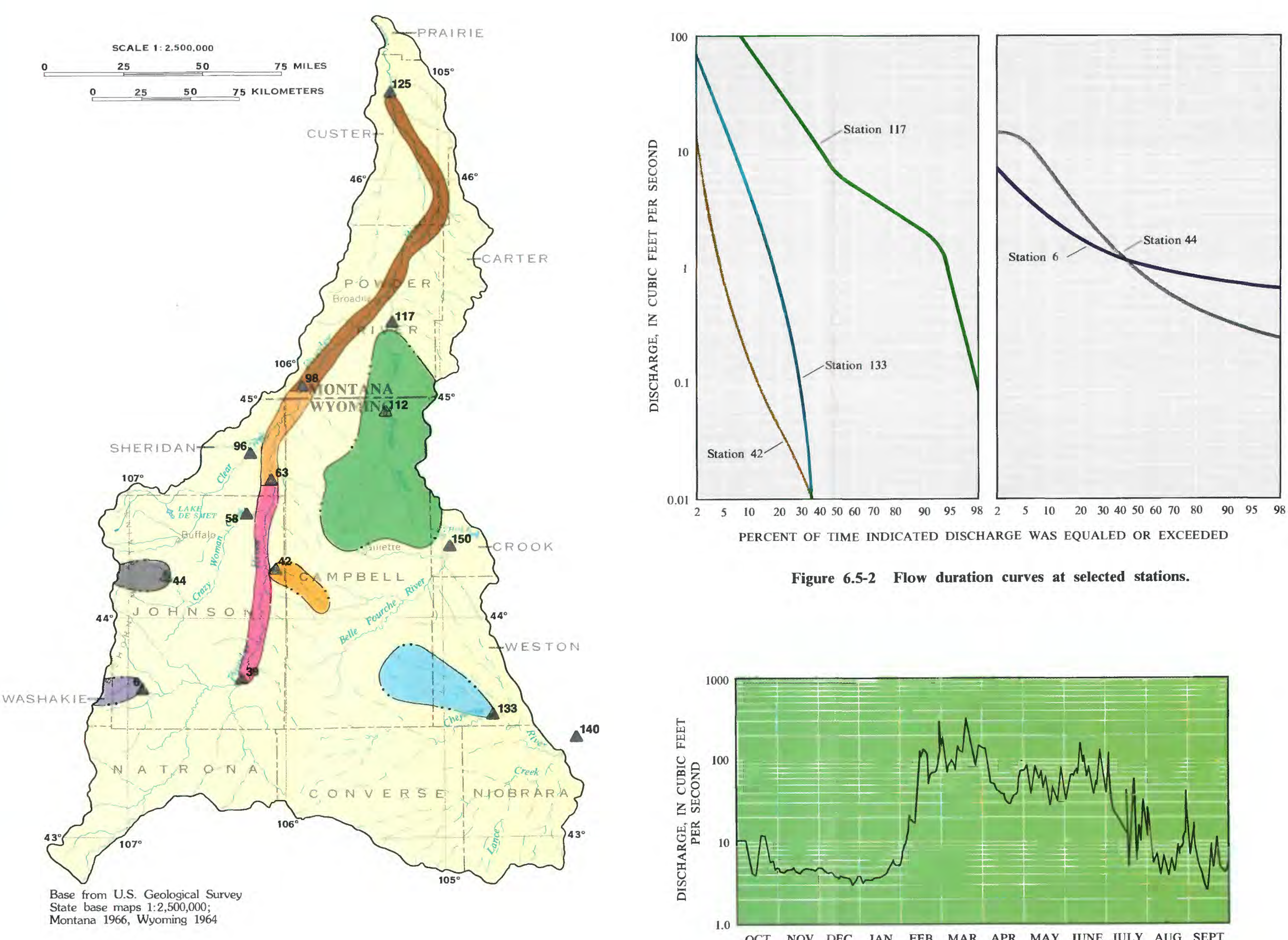

PERCENT OF TIME INDICATED DISCHARGE WAS EQUALED OR EXCEEDED

Figure 6.5-2 Flow duration curves at selected stations.

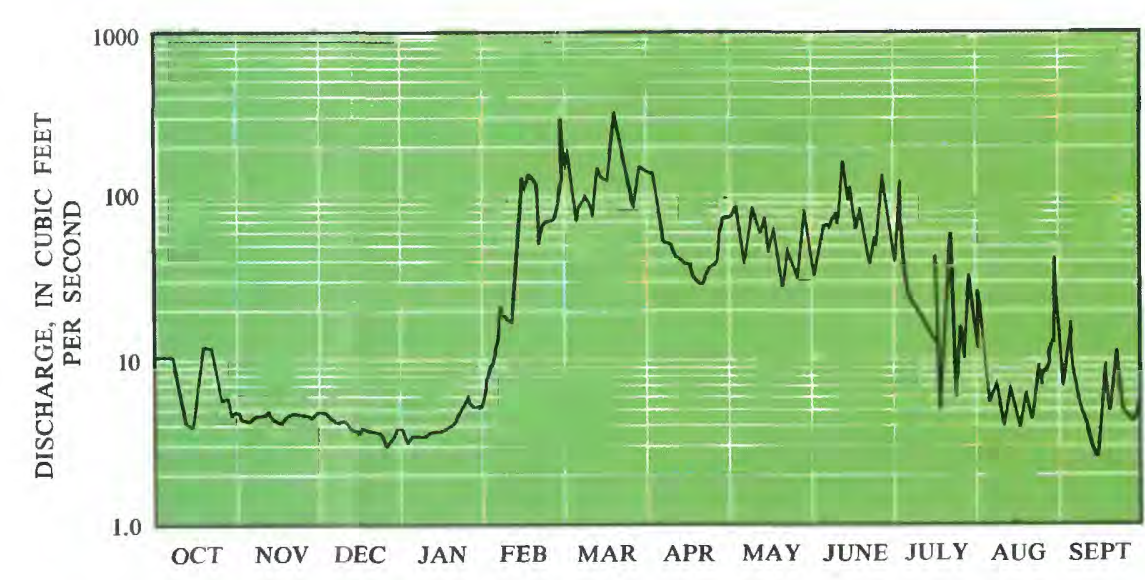

Figure 6.5-3 Average-discharge hydrograph for Little Powder

\section{EXPLANATION}

$\triangle 6$ STATION AND NUMBe

DRAINAGE BOUNDARY

RIVER REACH,
DESCRIBED IN FIGURE 6.5-1 


\title{
7.0 SURFACE-WATER QUALITY \\ 7.1 Chemical Quality \\ 7.1.1 Dissolved Solids
}

\section{High Dissolved-Solids Concentrations Common in Most Streams}

\author{
Average dissolved-solids concentrations at nearly all surface-water stations are significantly \\ greater than the national drinking-water standard of 500 milligram s per liter. Nearly one-half \\ of the stations have average and median concentrations exceeding 2,000 milligrams per liter. \\ Streams draining the Bighorn Mountains have the lowest dissolved-solids concentrations.
}

Frequent high dissolved-solids concentrations are characteristic of most of the area's streams (fig. 7.1.1-1). The average dissolved-solids concentrations at most stations are significantly higher than the $500-\mathrm{mg} / \mathrm{L}$ (milligram per liter) national secondary drinking-water standard recommended by the U.S. Environmental Protection Agency (1979). Nearly one-half of the stations have average and median dissolved-solids concentrations greater than $2,000 \mathrm{mg} / \mathrm{L}$. Two stations have maximum dissolved-solids concentrations greater than 7,000 $\mathrm{mg} / \mathrm{L}$. The highest determined dissolved-solids concentration at any of the area's surface-water stations was 7,870 $\mathrm{mg} / \mathrm{L}$ (station 141 in the Belle Fourche basin). In contrast, many streams in the Eastern States have much lower dissolved-solids concentrations. For example, many of the streams in central West Virginia, a coal-mining area, have average dissolved-solids concentrations of less than $100 \mathrm{mg} / \mathrm{L}$, and nearly all have dissolved-solids concentrations of less than $500 \mathrm{mg} / \mathrm{L}$ (Ehlke and others, 1982).

An important exception to the generally high dissolved-solids concentrations in the area's streams is evident at stations 22, 74, 75, 95, and 96 in the Powder River Basin. These stations are on streams that drain the Bighorn Mountains. Mountain streams are the source of the area's least mineralized water. They are important not only for the quality but also for the quantity of water they provide. The water from these streams is used primarily for irrigation but also provides important trout fisheries. However, Buffalo obtains its water from one of these mountain streams.

Another characteristic of the area's streams is the wide range of dissolved-solids concentrations at a station. The streams at some stations have a tenfold difference between minimum and maximum concentrations. Station 111 on the Little Powder River has a twentyfold difference between the minimum $(222 \mathrm{mg} / \mathrm{L})$ and the maximum $(4,450 \mathrm{mg} / \mathrm{L})$ analyzed dissolved-solids concentrations.

Dissolved-solids concentrations generally vary inversely with stream discharges. (See Rucker and DeLong, 1984.) The wide range in dissolved-solids concentrations at a station is primarily due to the wide range in stream discharges common in the area's streams.
Although the Little Powder, Belle Fourche, and Cheyenne are called rivers and have relatively large drainage areas (the size of Maryland or Rhode Island), they often have less streamflow than the use of the word "river" would imply. Most of the year these rivers could be stepped across without getting one's feet wet. During such low flows, the dissolved-solids concentrations are high. However, during periods of infrequent high flow, these streams do resemble rivers and have relatively low dissolved-solids concentrations. As a result, if a reservoir is constructed, the water in the reservoir would have a much lower dissolved-solids concentration than the average dissolved-solids concentration of the upstream stations would indicate. This is because concentrations of incoming water tend to be discharge-weighted, with more weight given to the larger volumes of water entering the reservoir during periods of high flow with low dissolved-solids concentrations than to smaller volumes entering during periods of low flow with high dissolved-solids concentrations.

Discharge-weighting may be explained by a hypothetical example. Imagine a stream flowing into an empty reservoir for 2 days. On the first day 1 volume enters the reservoir with a dissolved-solids concentration of $1,000 \mathrm{mg} / \mathrm{L}$. On the second day 9 volumes of water entered the reservoir with a dissolved-solids concentration of $200 \mathrm{mg} / \mathrm{L}$. On a "time-weighted" basis the average dissolved-solids concentration of the stream is $(1,000+$ $200) \div 20$, or $600 \mathrm{mg} / \mathrm{L}$. However, this would not be the concentration of the water in the reservoir. The concentration must be computed with a "discharge-weighted" average. Ten volumes entered the reservoir: 1 volume at $1,000 \mathrm{mg} / \mathrm{L}$ dissolved solids and 9 volumes at $200 \mathrm{mg} / \mathrm{L}$ dissolved solids. Therefore, the average dissolved-solids concen tration in the reservoir would be:

$(1$ volume $\times 1,000 \mathrm{mg} / \mathrm{L})+(9$ volumes $\times 200 \mathrm{mg} / \mathrm{L})$ (10 volumes), or $280 \mathrm{mg} / \mathrm{L}$

This discharge-weighting effect of Keyhole Reservoir on the Belle Fourche River explains why the dissolved-solids concentrations are less downstream from the reservoir (station 153) than upstream from the reservoir (station 141). 


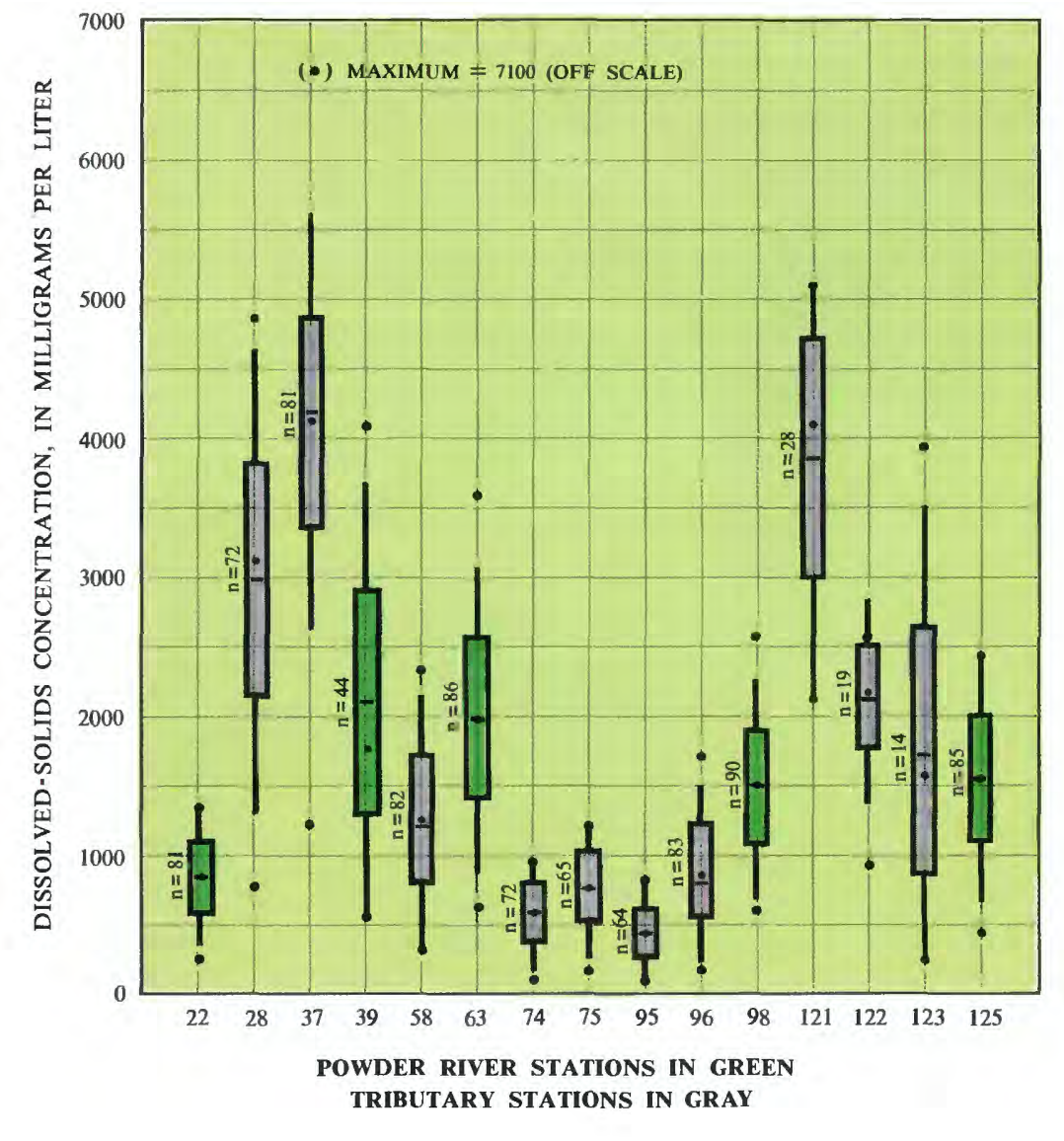

EXPLANATION

$\nabla^{28}$ STATION AND NUMBER DISSOLVED-SOLIDS CONCENTRATION,
IN MILIGRAMS PER IITER

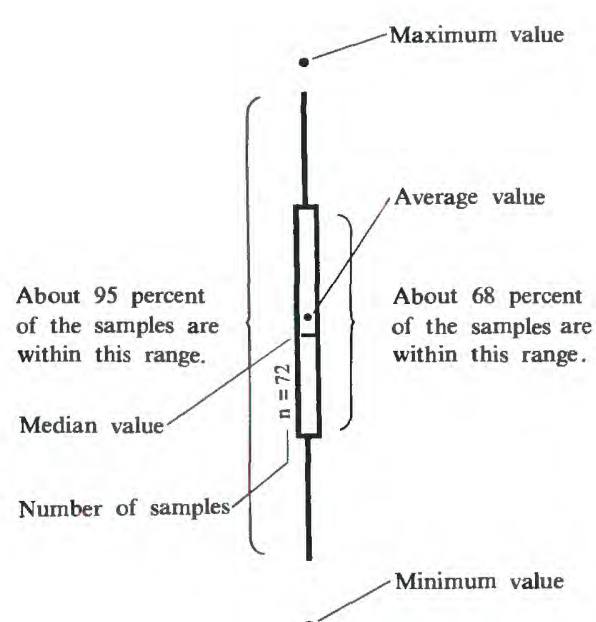

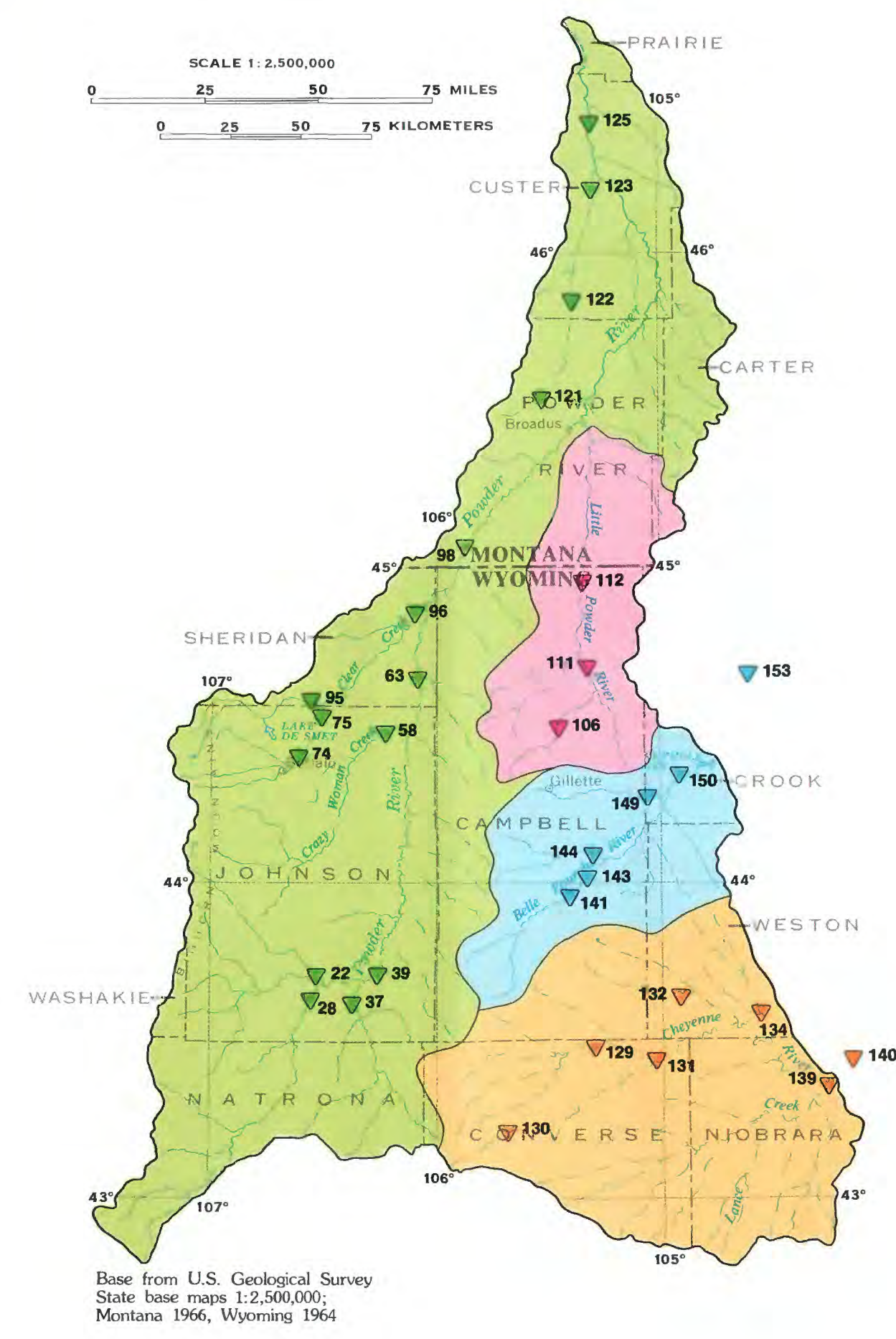

Figure 7.1.1-1 Dissolved-solids concentrations of the area's streams.
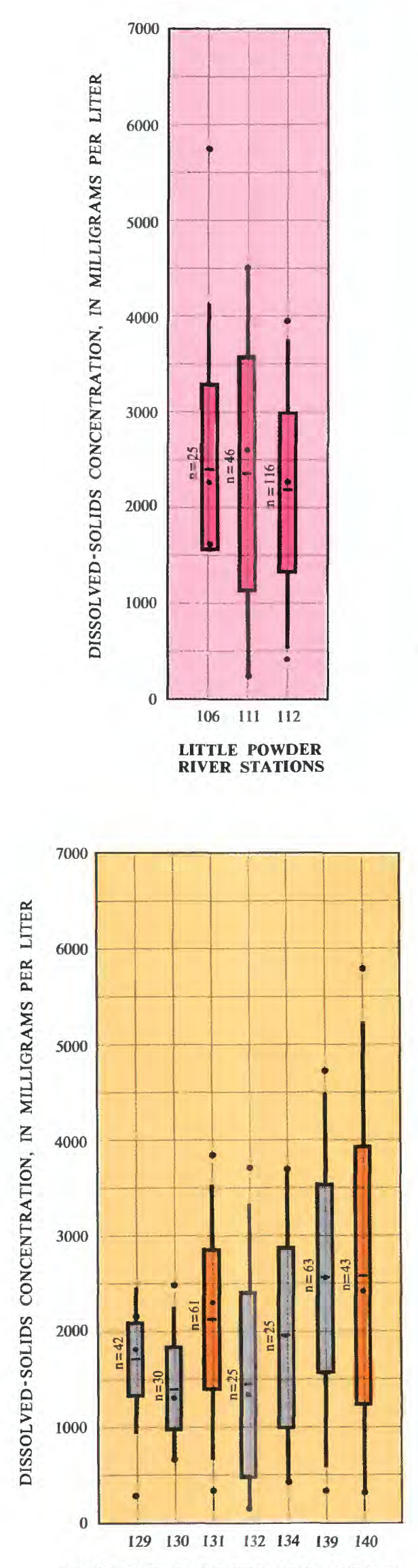

CHEYENNE RIVER STATIONS IN GOLD

TRIBUTARY STATON

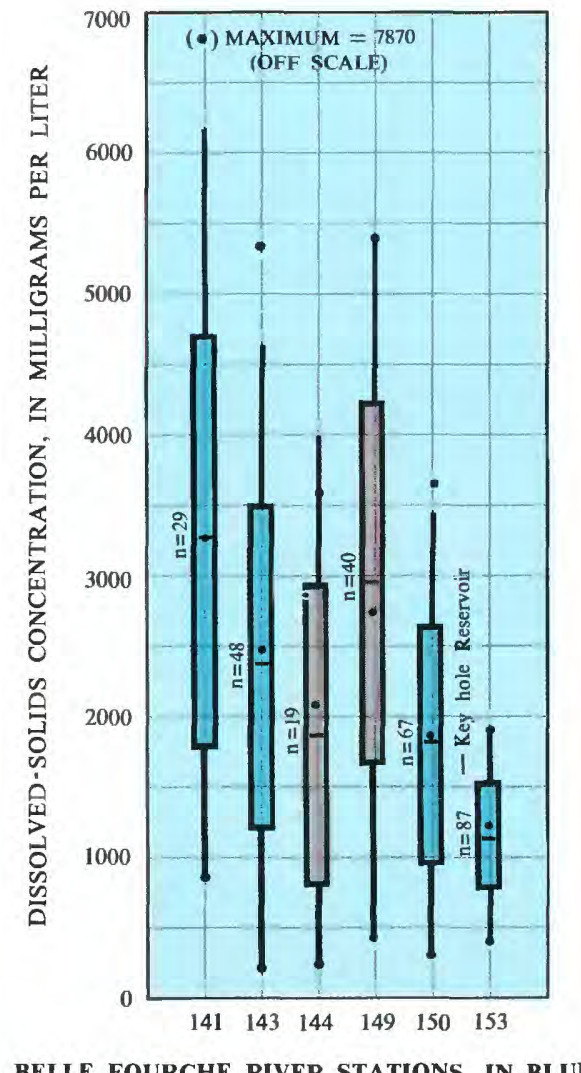

TRURCHE RTER STATONS IN BLUE TRIBUTARY STATIONS IN GRAY 


\title{
Dissolved-Solids Concentrations Vary Seasonally with Streamflow
}

\author{
Late spring and early summer snowmelt in the mountains increases streamflow in \\ the mountain streams. Spring runoff and summer rainstorms are seasonal factors \\ in streamflow for plains streams. Because dissolved-solids concentrations \\ generally are inversely related to streamflow, dissolved-solids concentrations \\ also vary seasonally.
}

Seasonal variations in streamflow account for much of the variability in stream quality. The seasonal pattern of streamflow and its effect on dissolved-solids concentrations are shown in figure 7.1.2-1 for a mountain stream (station 74), for the Powder River (station 125), and for a plains stream (station 139). The graphs are plots of average daily discharges overlaid with plots of the dissolved-solids concentrations from the 1976 monthly samples. The 1976 discharges (fig. 7.1.2-1) were slightly greater than average for the mountain stream and the Powder River station, but considerably less than average for the plains stream station.

Snowmelt from the heavy snowpack that accumulates in the mountains during the fall, winter, and spring flows into the mountain streams during May, June, and July, greatly augmenting the base flow of these streams as shown by the 1976 hydrograph of station 74. Because snowmelt dilutes the dissolved-solids concentration of the base flow, dissolved-solids concentration also varies seasonally.

The May, June, and July monthly samples at station 74 had dissolved-solids concentrations of 210 , 306 , and 217 milligrams per liter--considerably lower than in samples collected throughout the rest of the year. Although station 74 is used as an example for a mountain stream, it is actually representative of a mountain stream as it enters the plains. Some 13,000 acres are irrigated upstream from the site. Had data been collected upstream from the irrigated area, the dissolved-solids concentrations would have been less because irrigation return flow increases the dissolved-solids concentration of the stream.

The seasonal pattern of streamflow in the Pow- der River (station 125) is affected by runoff from both mountains and plains areas. The early peaks in streamflow during February, March, and April are due to increased runoff from the plains area from snowmelt and rainstorms. Even though streamflow increased during this period, the dissolved-solids concentrations remained relatively large because the runoff from the plains generally has a larger dissolved-solids concentration than the runoff from the mountains. In May and June the snowmelt from the mountain tributaries (such as station 74 ) was the source for most of the streamflow in the Powder River; the dissolved-solids concentrations decreased.

Station 139 is used as an example of a plains stream of the area. Runoff per unit area in the plains is much less than the runoff per unit area of the mountains. The semiarid plains do not normally accumulate a significant snowpack. Some years there may be none. Also, a significant base flow is lacking in plains streams, in contrast to the mountain streams. The 1976 hydrograph shown for station 139 had an average discharge of 7.4 cubic feet per second, considerably less than the 31-year average discharge ( 25.9 cubic feet per second). However, for consistency, the 1976 hydrograph is shown. An average year would likely have greater spring runoff from snowmelt and (or) spring rainstorms and a larger volume of runoff from summer rainstorms than that which occurred during 1976. Nonetheless, periods of both no flow and low flow are frequent in the plains streams. The graph for station 139 demonstrates two of the hydrologic problems for the plains area: (1) Not much surface water is available, and (2) the dissolved-solids concentrations of the streams generally are high. 


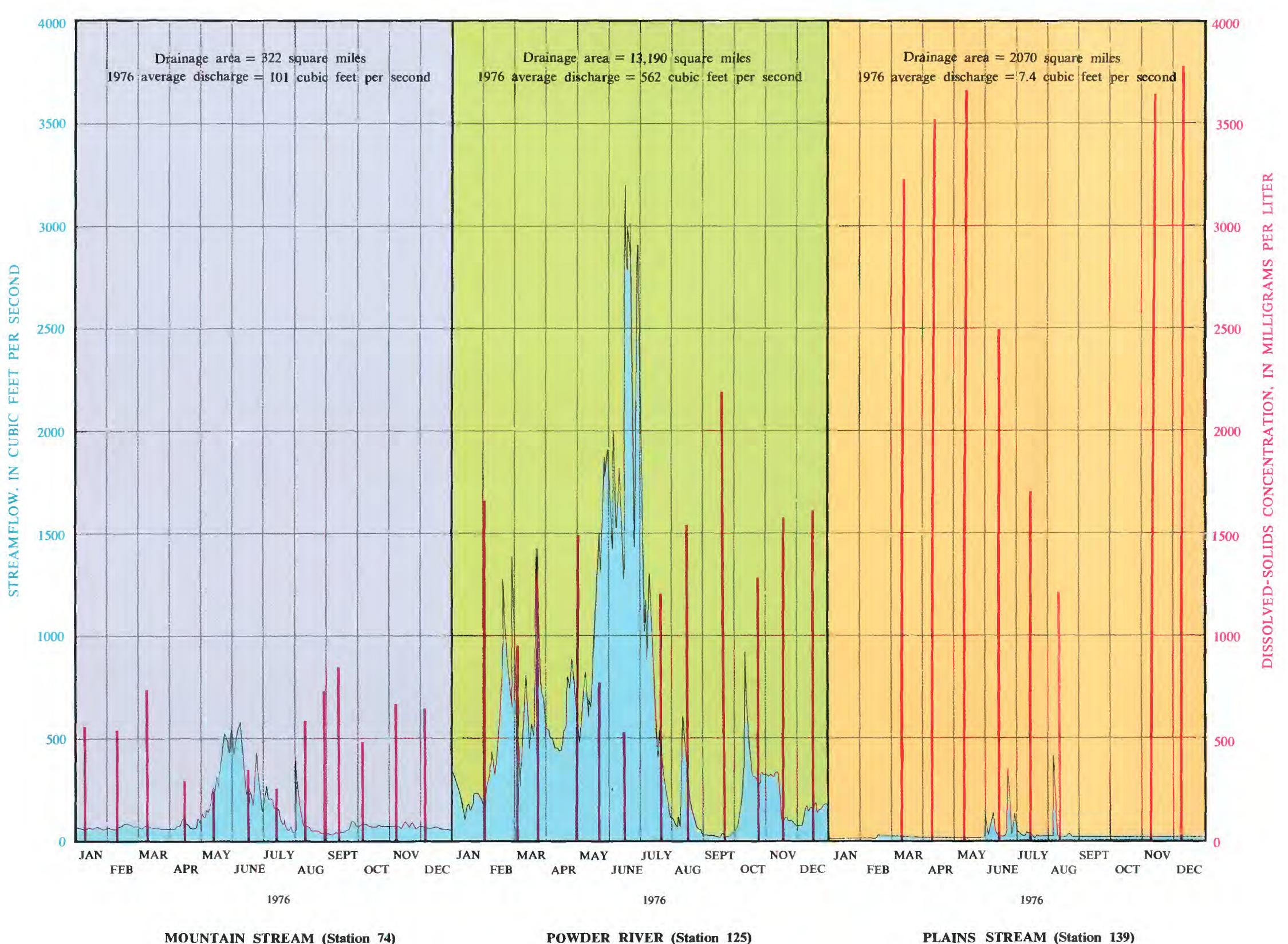

MOUNTAIN STREAM (Station 74)
POWDER RIVER (Station 125)

PLAINS STREAM (Station 139)

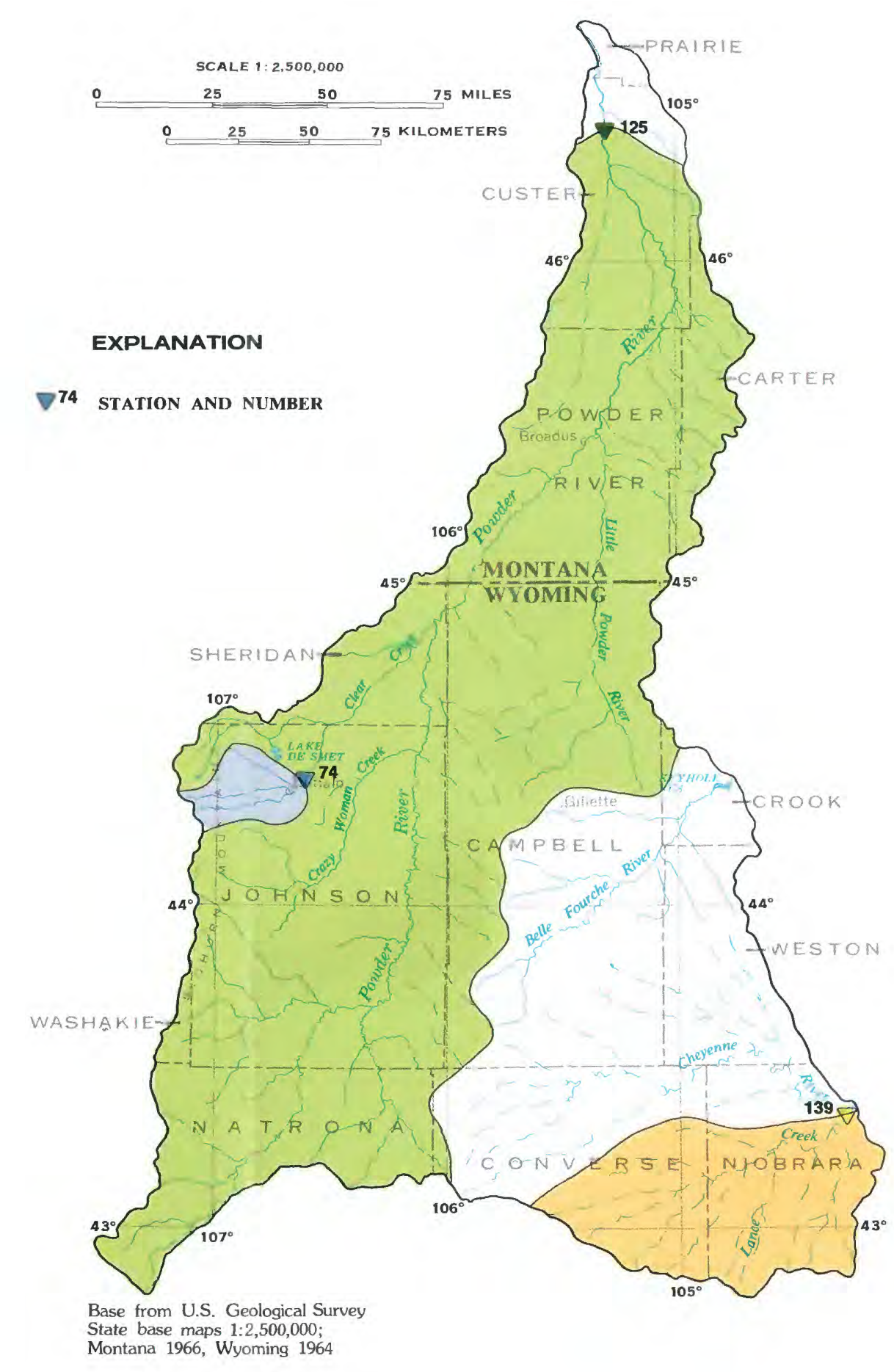

Figure 7.1.2-1 Seasonal variability of dissolved-solids concentrations and streamflow at three stations. 


\title{
7.0 SURFACE-WATER QUALITY--Continued \\ 7.1 Chemical Quality--Continued \\ 7.1.3 Alkalinity
}

\section{Alkalinity Concentrations Generally High Throughout the Area}

\author{
Average alkalinity concentrations at all stations exceed 100 milligrams per \\ liter; most stations have mean and median concentrations greater than 200 \\ milligrams per liter. These high alkalinity concentrations reduce the \\ risk of acid mine drainage.
}

\begin{abstract}
Alkalinity is a measure of the ability of water to neutralize an acid. In most natural waters alkalinity is almost entirely attributable to bicarbonate and carbonate ions. The concentrations of these ions in natural waters are extremely variable, ranging from almost none to greater than $1,000 \mathrm{mg} / \mathrm{L}$ (milligrams per liter). The principal sources of bicarbonate and carbonate ions in natural waters are soils and calcareous rocks such as limestone; the dissolution of atmospheric carbon dioxide also contributes some bicarbonate. Areas with thin soils and hard, crystaline bedrock are, therefore, more susceptible to damage from acid rain or acid mine drainage because the soils and surface waters do not have much capacity to neutralize acids.
\end{abstract}

The alkalinities of most of the area's streams are high. The mountain tributaries of the Powder River, however, have significantly lower alkalinities, especially during periods of high flow. All stations have average and median alkalinity concentrations in excess of $100 \mathrm{mg} / \mathrm{L}$, as calcium carbonate (fig. 7.1.3-1). Alkalinity concentrations traditionally are reported as an equivalent concentration of calcium carbonate. Streams at most chemical-quality, surface-water sta- tions in Area 50 have average alkalinity concentrations greater than $200 \mathrm{mg} / \mathrm{L}$, as calcium carbonate. In comparison, the average alkalinity of streams in a coal-mining area of central West Virginia is $27 \mathrm{mg} / \mathrm{L}$, with extremes ranging from 0 to $260 \mathrm{mg} / \mathrm{L}$ (Ehlke and others, 1982).

Acid mine drainage has not been a problem in Area 50, even though the ingredients required to produce sulfuric acid--pyrite (iron sulfide), moisture, and oxygen--are present. Any sulfuric acid produced by the oxidation of pyrite is neutralized by the high alkalinity of the area's streams.

Although acid mine drainage has not been a problem in the area's receiving streams, the Wyoming Department of Environmental Quality has identified a low-pH problem in soils. Acid production on some parcels of land reclaimed after coal mining has lowered the $\mathrm{pH}$ of the soil to the extent that revegetation efforts have been adversely affected (Dennis Fransway, written commun., 1983). The extent of this problem, however, is not well documented. 


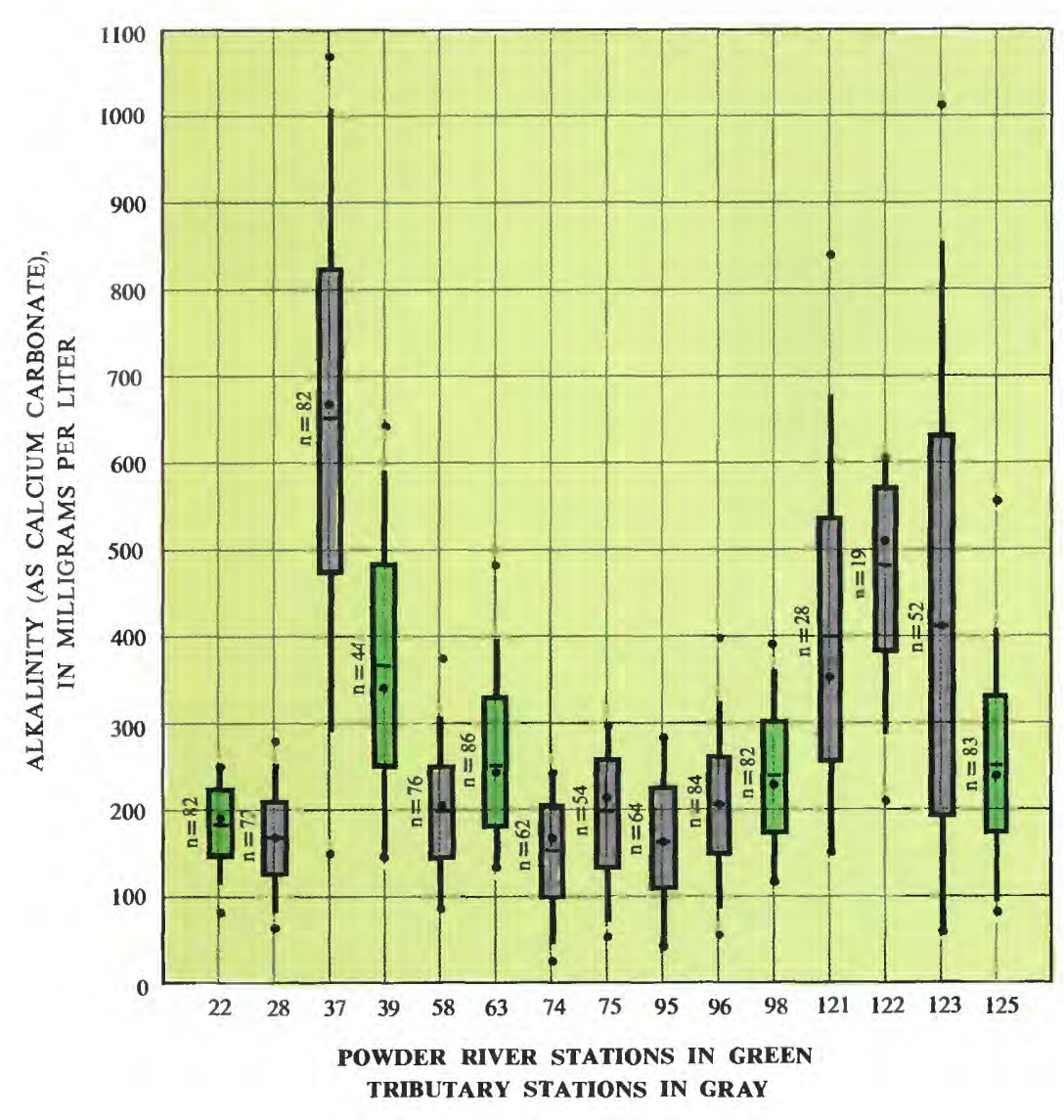

\section{EXPLANATION}

$\checkmark 39$ STATION AND NUMBER ALKALINITY (AS CALCIUM CARBONATE),$$
\begin{aligned}
& \text { About } 95 \text { percent } \\
& \text { of the samples are } \\
& \text { within this range. }
\end{aligned}
$$

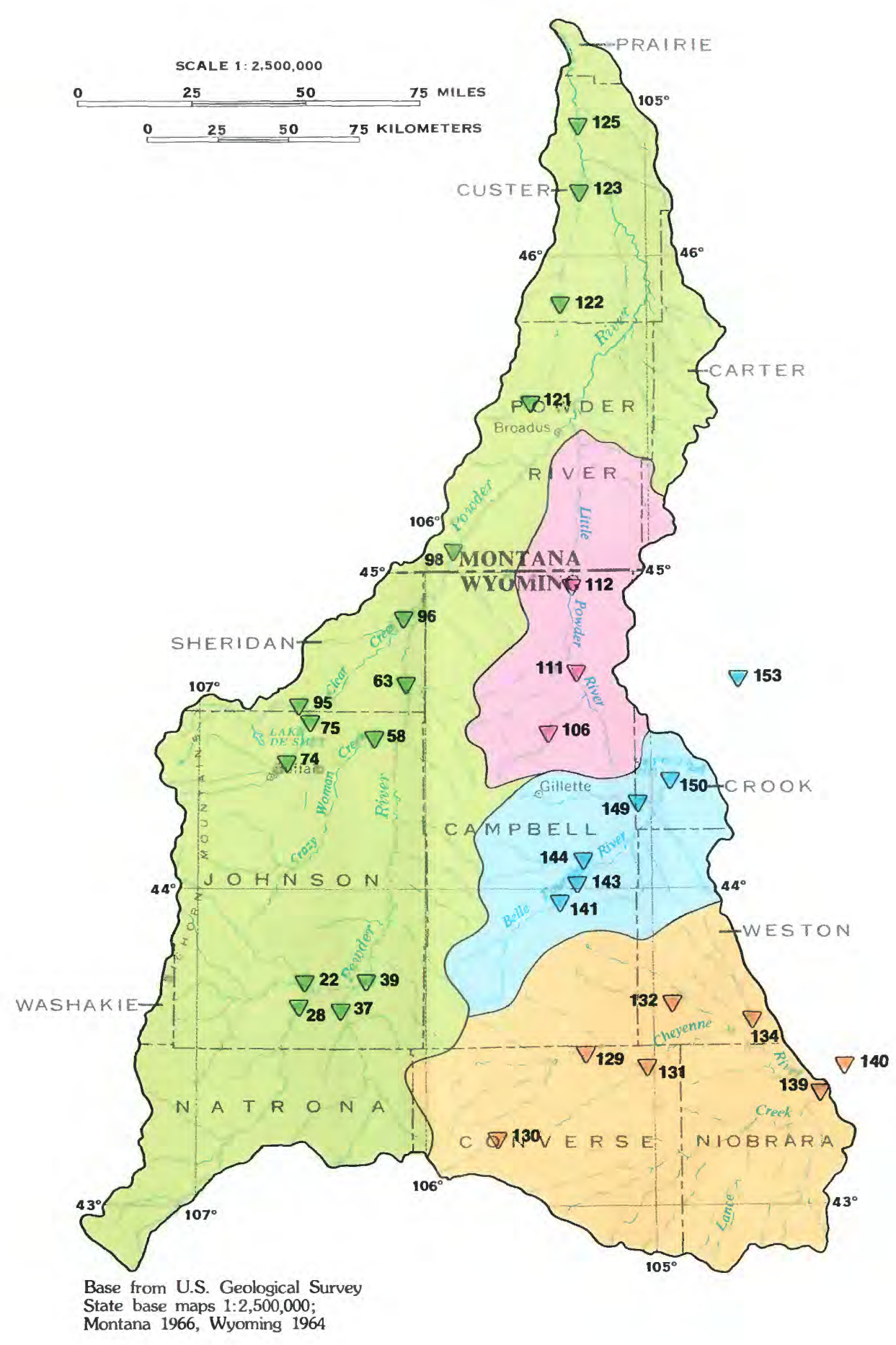

Figure 7.1.3-1 Alkalinity of the area's streams.
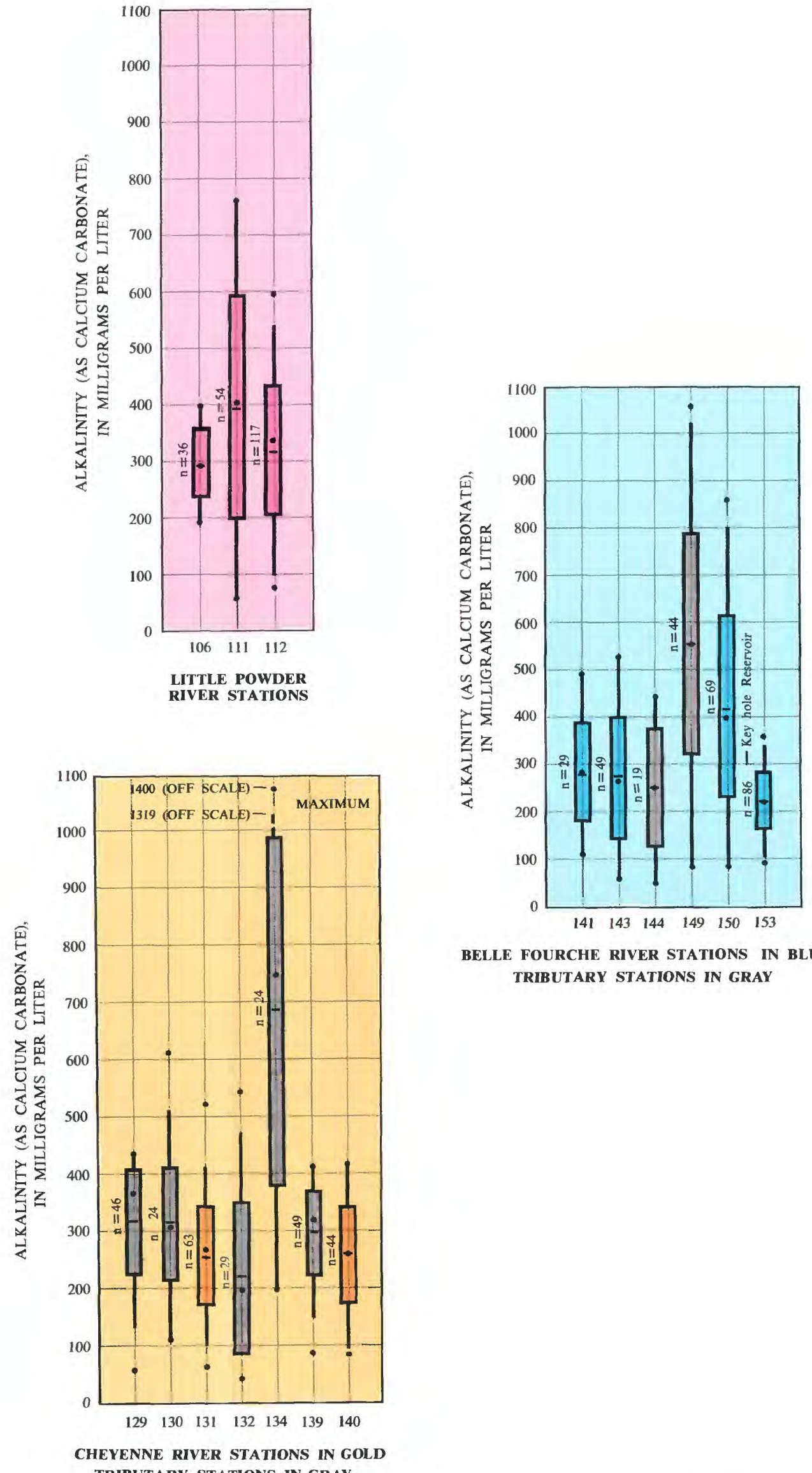

BELLE FOURCHE RIVER STATIONS IN BLU Th 


\title{
7.0 SURFACE-WATER QUALITY--Continued \\ 7.1 Chemical Quality--Continued \\ 7.1.4 pH
}

\section{Acid Mine Drainage Not a Problem}

\author{
Surface-water $\mathrm{pH}$ values tend to be alkaline, even downstream from mine \\ sites. Nearly all $\mathrm{pH}$ measurements are above 7 , and nearly all meet \\ recommended criteria.
}

\begin{abstract}
Unlike some coal areas in the Eastern States, acid mine drainage is not a problem in this area. The area's streams, even those that receive ground water directly from the coal mines, generally have high $\mathrm{pH}$ values, as shown in figure 7.1.4-1. The relatively high alkalinity of the area's soils, surface water, and ground water provides a large buffering capacity that tends to neutralize any sulfuric acid that might be formed through the oxidation of pyrite or other sulfide minerals that may accompany coal-mining operations.
\end{abstract}

The $\mathrm{pH}$ criterion for untreated water used as a source for public supplies specifies a permissible range of 5 to $9 \mathrm{pH}$ units (U.S. Environmental Protection Agency, 1976). The $\mathrm{pH}$ of treated water is easily adjusted if the $\mathrm{pH}$ of the untreated water is within the 5-to-9 range. All surface waters measured in the area have a $\mathrm{pH}$ greater than 5 (none are below $\mathrm{pH}$ 6.1). A few isolated $\mathrm{pH}$ measurements were greater than 9.0 (the maximum $\mathrm{pH}$ value was 9.1).

To protect freshwater aquatic lifeforms, a $\mathrm{pH}$ range of 6.5 to 9.0 is recommended by the U.S. Environmental Protection Agency (1976). This pH range provides protection for fish as well as for aquatic biota in the food chain for fish. Nearly all surface-water $\mathrm{pH}$ measurements for this area meet this 6.5-to-9.0 criterion.

The $\mathrm{pH}$ of water is of concern not only for the direct effect of $\mathrm{pH}$ on water quality, but also because the toxicity of some substances is dependent on $\mathrm{pH}$. For instance, hydrogen sulfide and hydrogen cyanide both become more toxic to fish with decreasing $\mathrm{pH}$. ln contrast, ammonia becomes more lethal as the $\mathrm{pH}$ increases.

It is important to keep in mind that $\mathrm{pH}$ is a measurement of the hydrogen-ion concentration. Pure waters and all water solutions dissociate to some extent, normally producing minute concentrations of hydrogen $\left(\mathrm{H}^{+}\right)$and hydroxyl $\left(\mathrm{OH}^{-}\right)$ions. If the concentration of hydrogen ions is equal to the concentration of hydroxyl ions, the water is neutral $(\mathrm{pH}=7)$. If the hydrogen-ion concentration is greater than the hydroxyl-ion concentration, the water is acidic $(\mathrm{pH}<7)$. Conversely, it is basic (alkaline) if the hydroxyl ion concentration is greater $(\mathrm{pH}>7)$. In a neutral solution, at $25^{\circ}$ Celsius, the concentrations of both the hydrogen and hydroxyl ions are 0.0000001 moles per liter. (A mole is the molecular weight expressed in grams.) Because the hydrogen and hydroxyl ion concentrations normally are so low, their concentrations are more conveniently expressed as the negative logarithms, which are defined as $\mathrm{pH}$ and $\mathrm{pOH}$, respectively:

$$
\mathrm{pH}=-\log _{10}\left[\mathrm{H}^{+}\right],
$$

where $\left[\mathrm{H}^{+}\right]=$the hydrogen-ion concentration in moles per liter.

$$
\mathrm{pOH}=-\log _{10}\left[\mathrm{OH}^{-}\right],
$$

where $\left[\mathrm{OH}^{-}\right]=$the hydroxyl-ion concentration in moles per liter.

The approximate relationships of $\mathrm{pH}, \mathrm{pOH}$, and the hydrogen-ion concentration to one another are given in table 7.1.4-1. Because $\mathrm{pH}$ is the negative logarithm of the hydrogen-ion concentration, an increase of $1 \mathrm{pH}$ unit represents a tenfold decrease in the hydrogen-ion concentration; an increase of $2 \mathrm{pH}$ units, a hundredfold decrease; and an increase of 3 $\mathrm{pH}$ units, a thousandfold decrease. Thus, the permissible $\mathrm{pH}$ range of 5 to 9 (for raw water for public supplies) allows a ten-thousandfold variation in the hydrogen-ion concentration. The $\mathrm{pH}$ scale ranges from 0 to 14, with a $\mathrm{pH}$ of 7 being neutral. 
Table 7.1.4-1-Relationship (approximate) of $\mathrm{pH}, \mathrm{pOH}$ and hydrogen-ion concentrations $(\mathrm{H})$

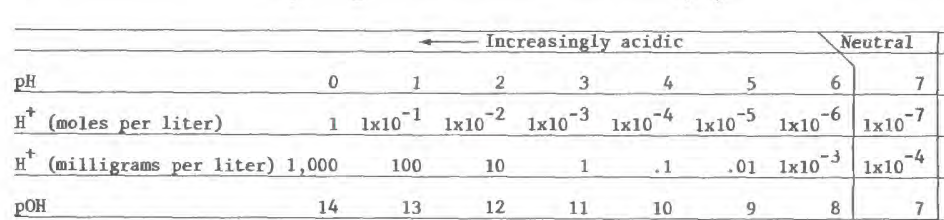

\begin{tabular}{llll}
\hline Increasingly basic $\longrightarrow$. & & \\
\hline
\end{tabular}

\begin{tabular}{lrrrrrrr}
\hline pH & 8 & 9 & 10 & 11 & 12 & 13 & 14 \\
$\mathrm{H}^{+}$(moles per 1iter) & $10^{-8}$ & $10^{-9}$ & $10^{-10}$ & $10^{-11}$ & $10^{-12}$ & $10^{-13}$ & $10^{-14}$ \\
\hline $4^{4}$ (
\end{tabular}

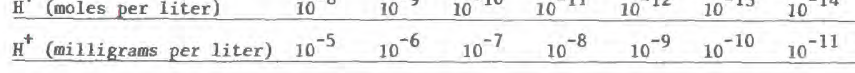

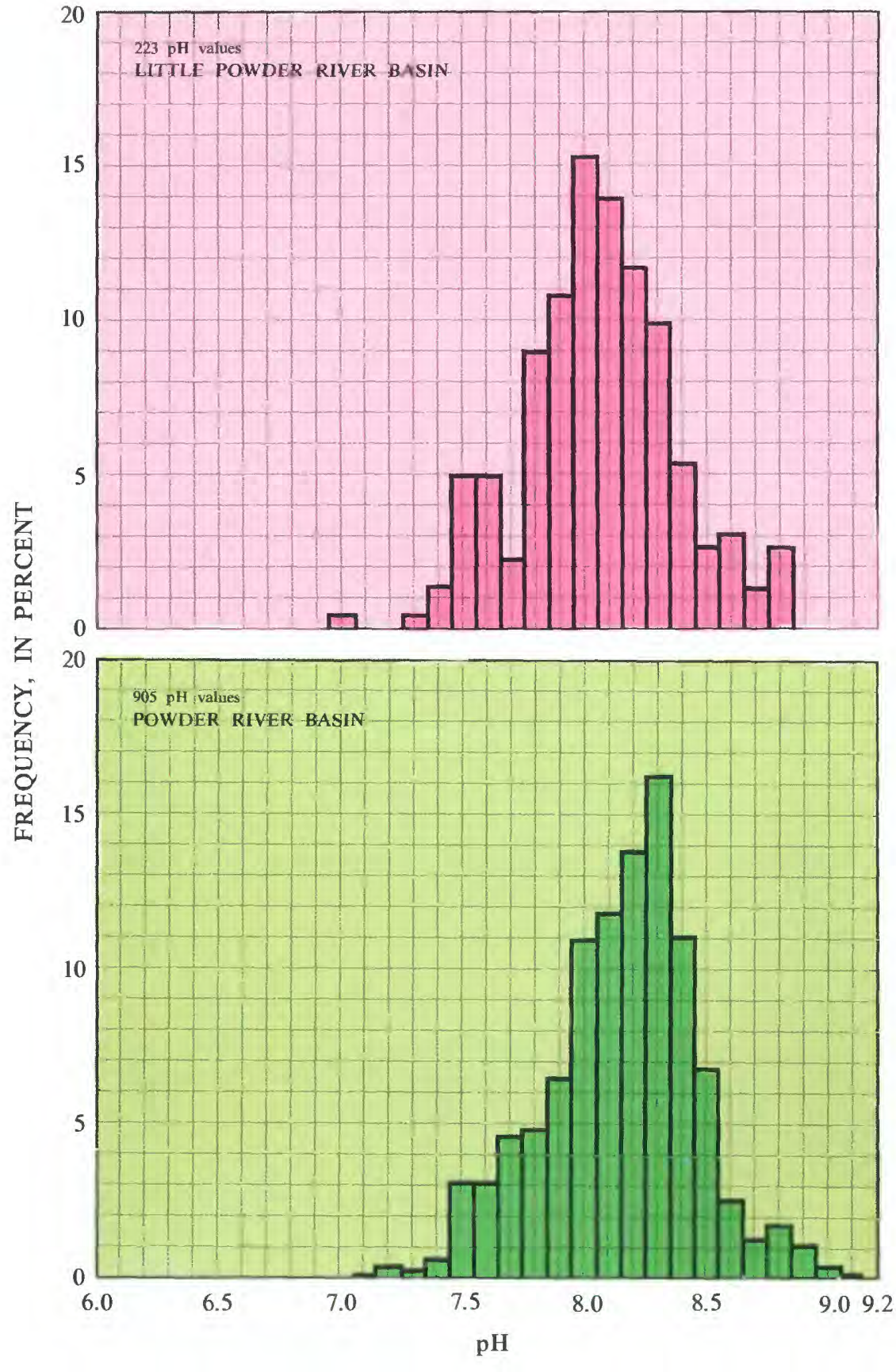

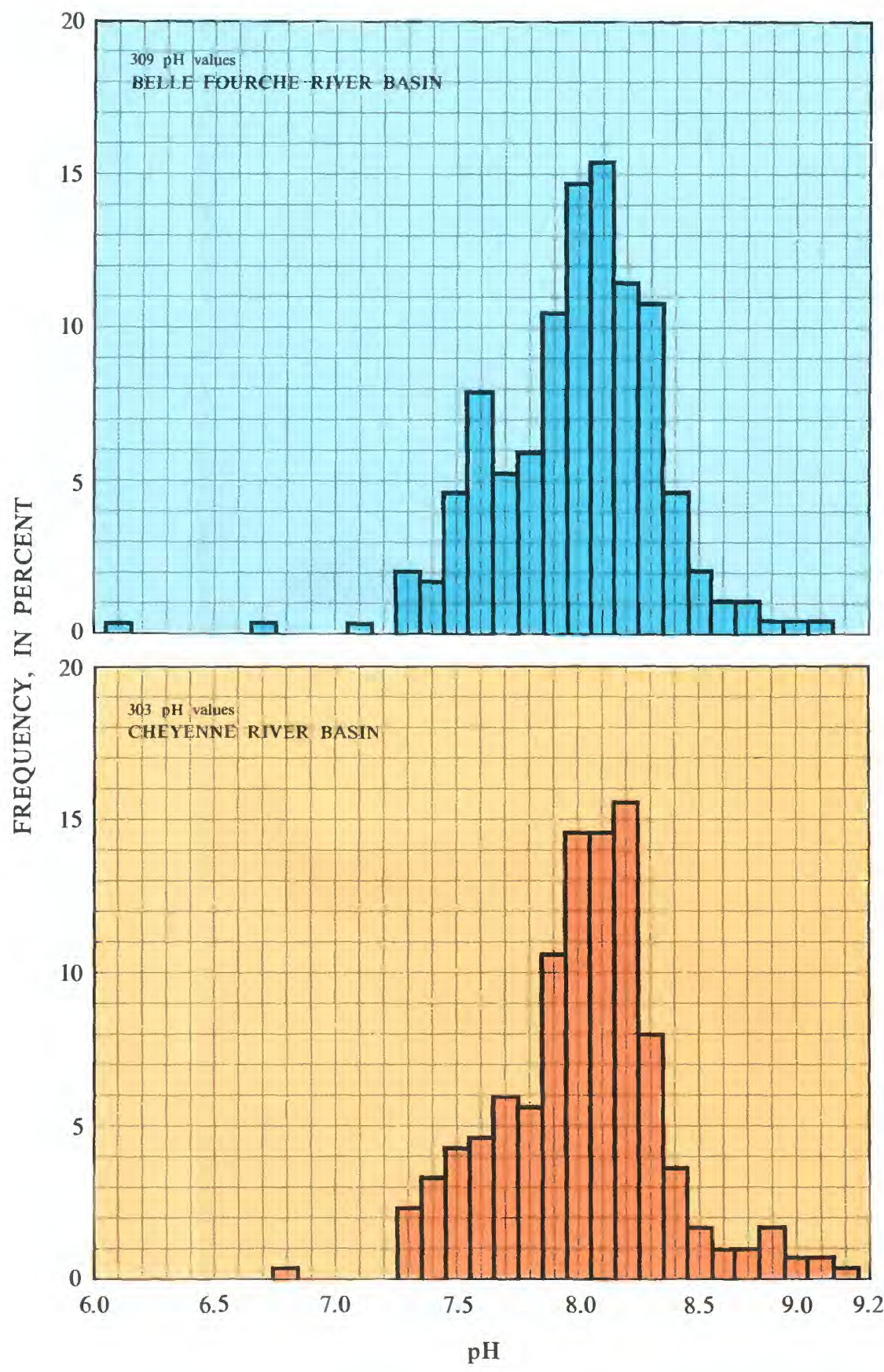

Figure 7.1.4-1 Histograms of $\mathrm{pH}$ values.

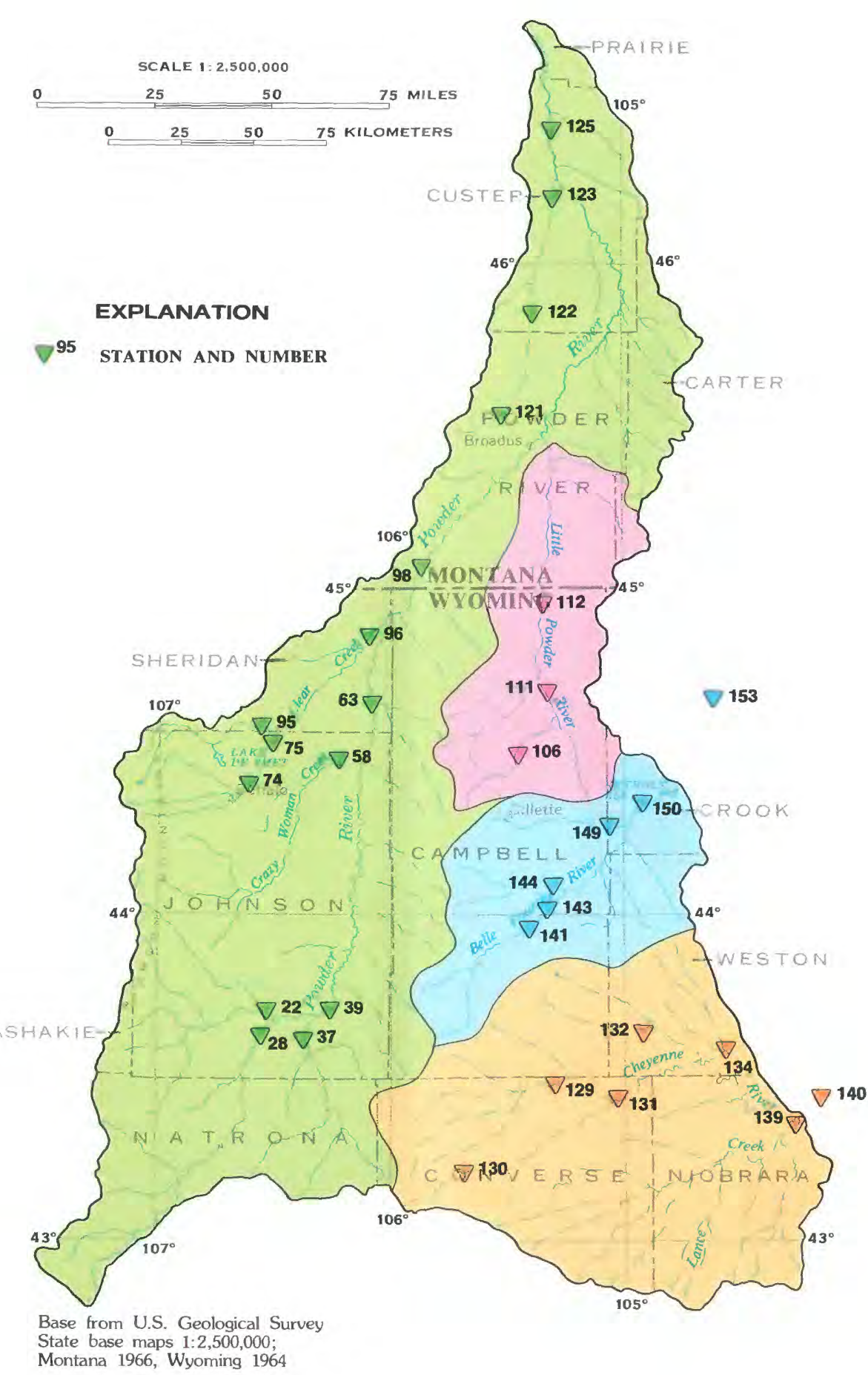




\title{
7.0 SURFACE-WATER QUALITY--Continued \\ 7.1 Chemical Quality--Continued \\ 7.1.5 Ionic Composition
}

\section{Sodium and Sulfate Generally Dominant Ions}

\begin{abstract}
Sodium and sulfate generally are dominant ions, except in mountain streams, where calcium, magnesium, and bicarbonate are predominant. Chloride is the major anion in Salt Creek due to the inflow of oilfield-production water.
\end{abstract}

In most of the area's streams sodium is the major cation and sulfate the major anion. Median ionic compositions of some of the areas streams are shown in figure 7.1.5-1. Calcium and magnesium, though generally not the dominant ions, are present in high enough concentrations to make water from streams of the area very hard.

In the Eastern States, high sulfate concentrations in streams generally are indicative of acid mine drainage from coal mines. By eastern standards, the sulfate concentrations of this area's streams would be abnormally high. The median sulfate concentration at station 112 is $1,300 \mathrm{mg} / \mathrm{L}$ (milligrams per liter); however, the high sulfate concentrations at this and other stations are not accompanied by low $\mathrm{pH}$ values that are characteristic of acid mine drainage.

The area's mountain streams are represented by station 95 in figure 7.1.5-1. Mountain streams differ from the other streams in the area by having a much lower total-ionic concentration and by having a different ionic composition. The percentages of magnesium, calcium, and bicarbonate ions are significantly higher and the percentages of sodium and sulfate ions are lower than those of the plains streams. However, mountain streams tend to become enriched in sodium and sulfate in their downstream reaches. Use of these streams for irrigation probably accelerates the normal downstream enrichment in sodium and sulfate ions, due to the relatively high concentrations of these ions in the irrigation return flow.

The ionic composition of Salt Creek (station 37) is unique for the area, due to the addition of oilfieldproduction water into the Salt Creek drainage. The high sodium and chloride concentrations in the production water alter the natural composition of Salt Creek. The chloride concentration is unusually high for streams of this area and even has considerable effect on the chloride concentration of Powder River downstream from Salt Creek, particularily when the flow of Powder River upstream from Salt Creek is low. 

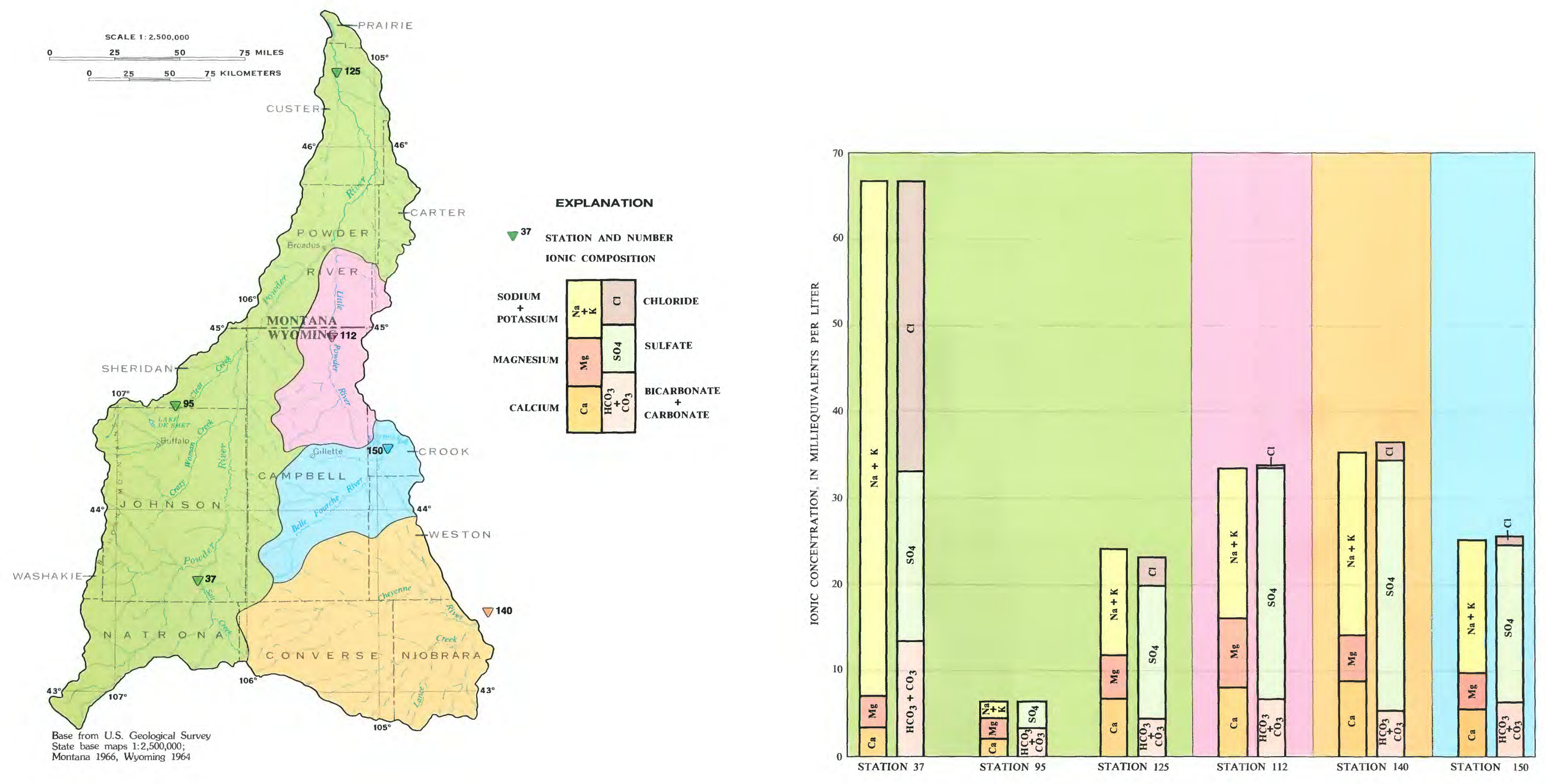


\title{
7.0 SURFACE-WATER QUALITY--Continued \\ 7.1 Chemical Quality--Continued \\ 7.1.6 Total Phosphorus
}

\section{Phosphorus Concentrations High in Most Streams}

\author{
Total-phosphorus concentrations, associated with high suspended-sediment \\ concentrations, are high in most streams, especially the Powder River. The total- \\ phosphorus criterion to protect reservoirs frequently is exceeded by the water in \\ the Belle Fourche River flowing into Keyhole Reservoir.
}

The Powder River is aptly named, for the stream transports a large sediment load. High sediment concentrations result in high totalphosphorus concentrations. The relationship of total-phosphorus concentrations to suspendedsediment concentrations for the Powder River stations is shown in figure 7.1.6-1.

Simple statistics for total-phosphorus concentrations in water for the streams of the area are shown in figure 7.1.6-2. Total-phosphorus concentrations for the stations on the main stem of Powder River average $0.58 \mathrm{mg} / \mathrm{L}$ (milligram per liter), significantly higher than the other drainages in the area and more than twice the average for the Nation's streams, which is about $0.24 \mathrm{mg} / \mathrm{L}$ (Briggs and Ficke, 1978). Most streams in the area have an increase in phosphorus concentration in the downstream direction. The principal exception is between stations 150 and 153. The decrease in phosphorus at station 153 is due to the presence of Keyhole Reservoir between the two stations. The reservoir is both a sediment and a phosphorus trap.

High concentrations of phosphorus are objectionable primarily because phosphorus promotes nuisance growth of algae and other aquatic plants in lakes, reservoirs, and streams. A maximum concentration of $0.1 \mathrm{mg} / \mathrm{L}$ total phosphorus (as phosphorus) has been suggested to protect streams which do not flow into lakes or reservoirs (Mackenthum, 1973). Lakes and reservoirs are more prone to algal problems than streams. To protect lakes and reservoirs, inflowing streams should not have total-phosphorus concentrations in excess of 0.05 mg/L (U.S. Environmental Protection Agency, 1976). This criterion frequently is exceeded in the Belle Fourche River above Keyhole Reservoir (station 150); there, the mean total-phosphorus concentration is $0.23 \mathrm{mg} / \mathrm{L}$ and the median is $0.13 \mathrm{mg} / \mathrm{L}$. However, because algal growth presently is not a problem at Keyhole Reservoir, other factors limiting algal growth evidently are involved.

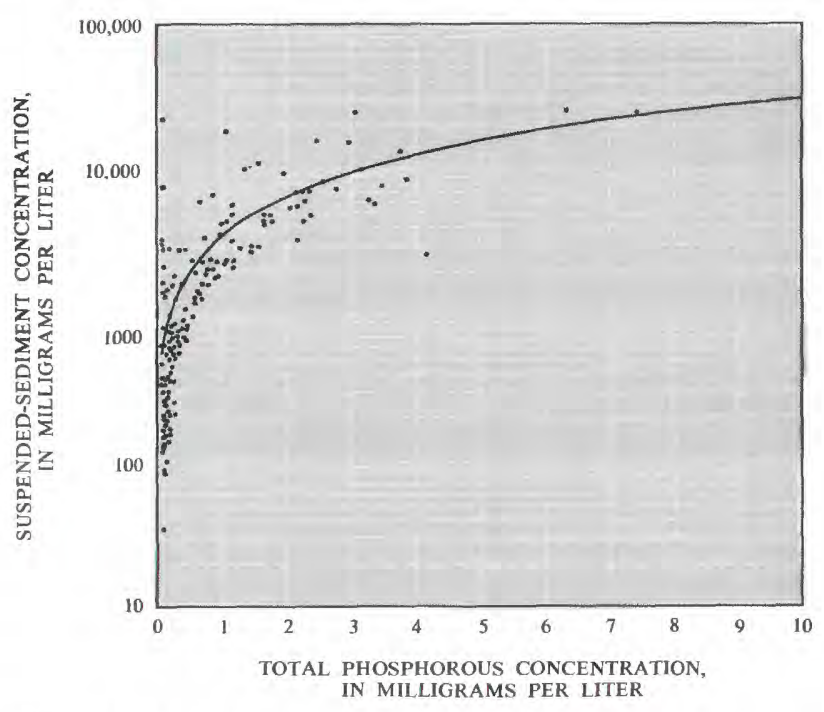

Figure 7.1.6-1 Total-phosphorus versus suspended-sediment concentrations (Powder River stations). 


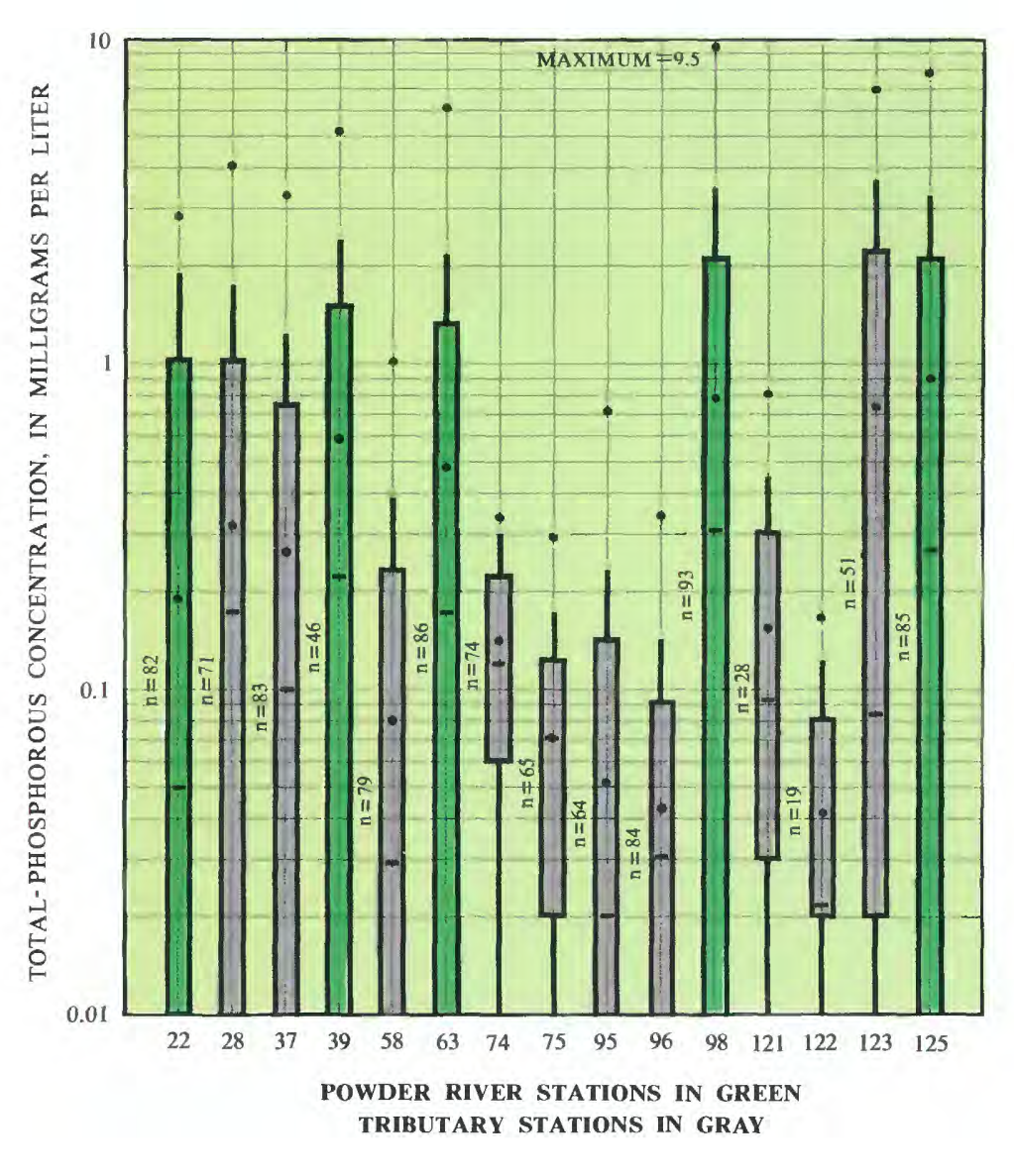

EXPLANATION

$\nabla^{95}$ STATION AND NUMBer

TOTAL-PHOSPHOROUS CONCENTRATION,

- Maximum value

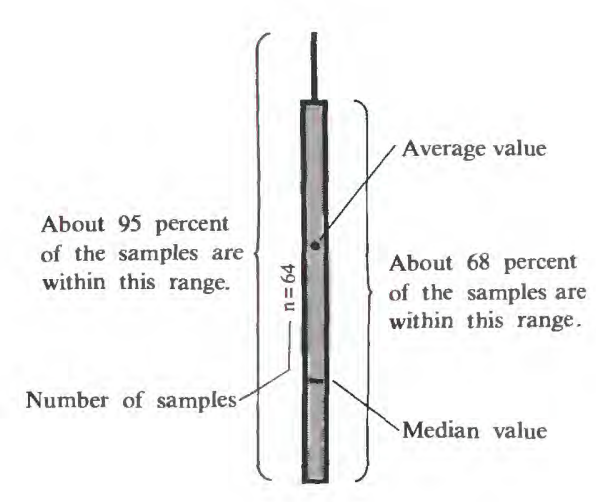

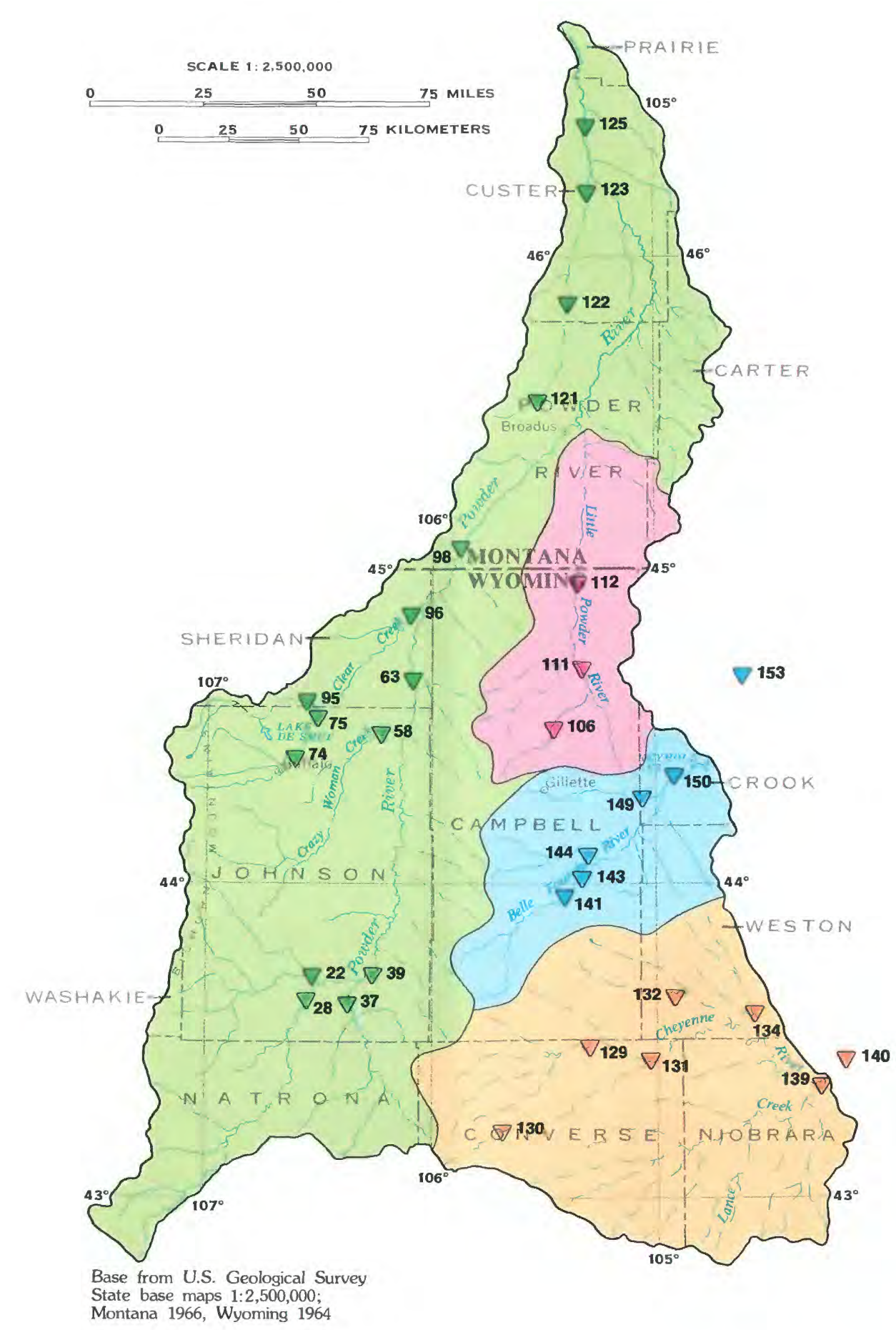

Figure 7.1.6-2 Total-phosphorus concentrations of the area's streams.
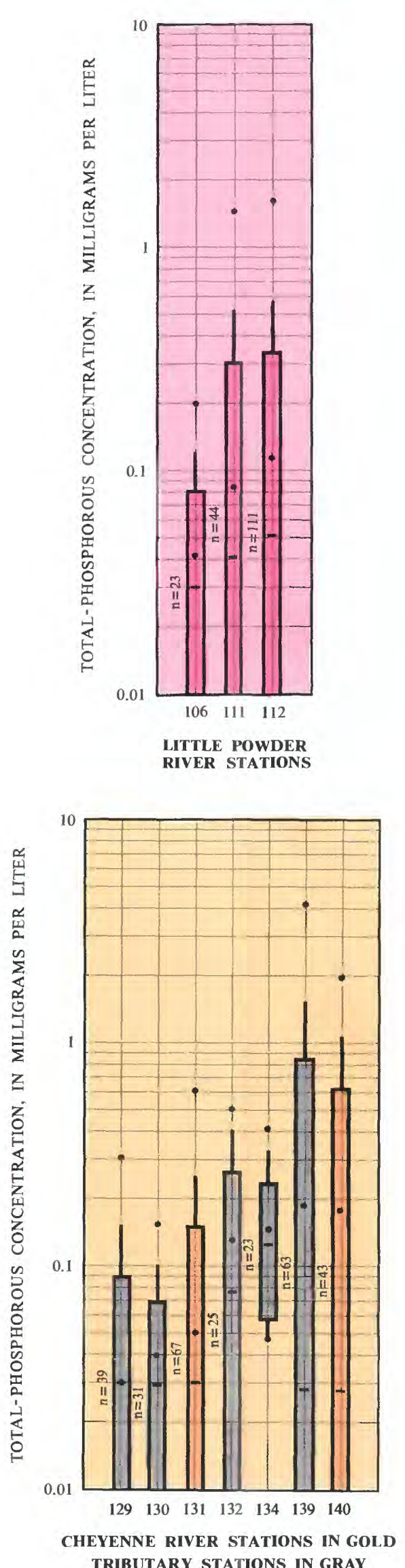

7.0 SURFACE-WATER QUALITY--Continued 7.1 Chemical Quality-Continued

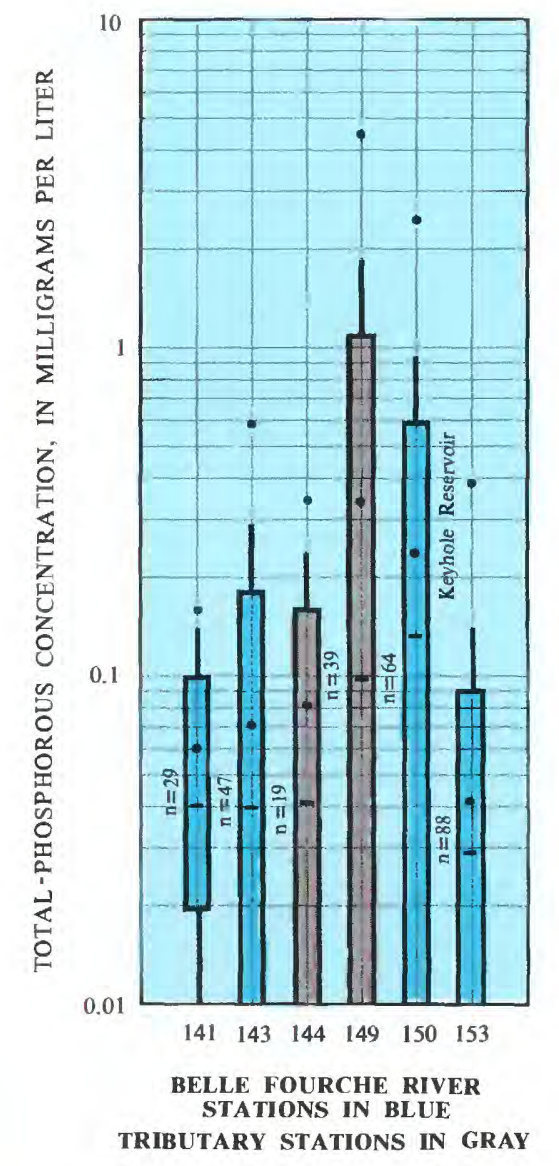




\title{
7.0 SURFACE-WATER OUALITY--Continued \\ 7.1 Chemical Quality--Continued \\ 7.1.7 Trace Metals
}

\section{Selenium Concentrations High in South Fork Powder River}

\author{
Trace metals generally are not a problem in the area's streams; exceptions are \\ high concentrations of selenium in the South Fork Powder River and high \\ concentrations of manganese and iron in some samples throughout the area.
}

\begin{abstract}
Although only 8 of nearly 400 dissolved-selenium analyses (table 7.1.7-1) have concentrations greater than the $10 \mu \mathrm{g} / \mathrm{L}$ (micrograms per liter) national primary drinking-water standard established by the U.S. Environmental Protection Agency (1977), the pattern of the occurrence of these high values indicates a local problem. Most of the samples with selenium concentrations greater than $10 \mu \mathrm{g} / \mathrm{L}$ were collected at South Fork Powder River near Kaycee, Wyo., station 28 (fig. 7.1.7-1). Six of the eight samples collected at this station have concentrations greater than the drinking-water standard. Even though the selenium concentrations at this station generally exceed the drinking-water standard, it does not constitute a problem, because the water is not used for a public supply. Nor are the selenium concentrations high enough to cause a problem when the water is used for watering livestock. Selenium in water is not a documented cause of selenium poisoning of livestock. Nonetheless, a maximum concentration of $50 \mu \mathrm{g} / \mathrm{L}$ is suggested by the National Academy of Sciences and National Academy of Engineering (1973) to protect livestock. High selenium concentrations in the basin's surface water indicate the presence of seleniferous soils. When these soils are present, certain plants take up and concentrate selenium to concentrations as high as several thousand parts per million (selenium to dry plant weight). Such plants are very toxic to animals that eat them, causing selenium poisoning that often is
\end{abstract}

fatal. Some of the analyses at station 28 also exceed the $20 \mu \mathrm{g} / \mathrm{L}$ maximum selenium concentration recommended by the National Academy of Sciences and National Academy of Engineering (1973) for irrigation water.

Manganese concentrations exceeded the $50 \mu \mathrm{g} / \mathrm{L}$ secondary drinking-water standard (U.S. Environmental Protection Agency, 1979) in about 56 percent of the samples. Iron values exceeded the $300 \mu \mathrm{g} / \mathrm{L}$ secondary drinking-water standard (U.S. Environmental Protection Agency, 1979) in about 3 percent of the samples. High concentrations of manganese and iron could cause esthetic problems (bitter taste and staining of plumbing fixtures) if present in a domestic water supply; however, such problems can be alleviated by water treatment and storage. The manganese and iron concentrations do not pose problems for the watering of livestock or for irrigation of crops.

The other potentially toxic trace metals that occurred in concentrations higher than the national primary drinking-water standards--cadmium, lead, and mercury--occurred in high concentrations so infrequently and with such lack of definite pattern that it is probable that no persistent problem with these trace metals exists in the area's streams. 


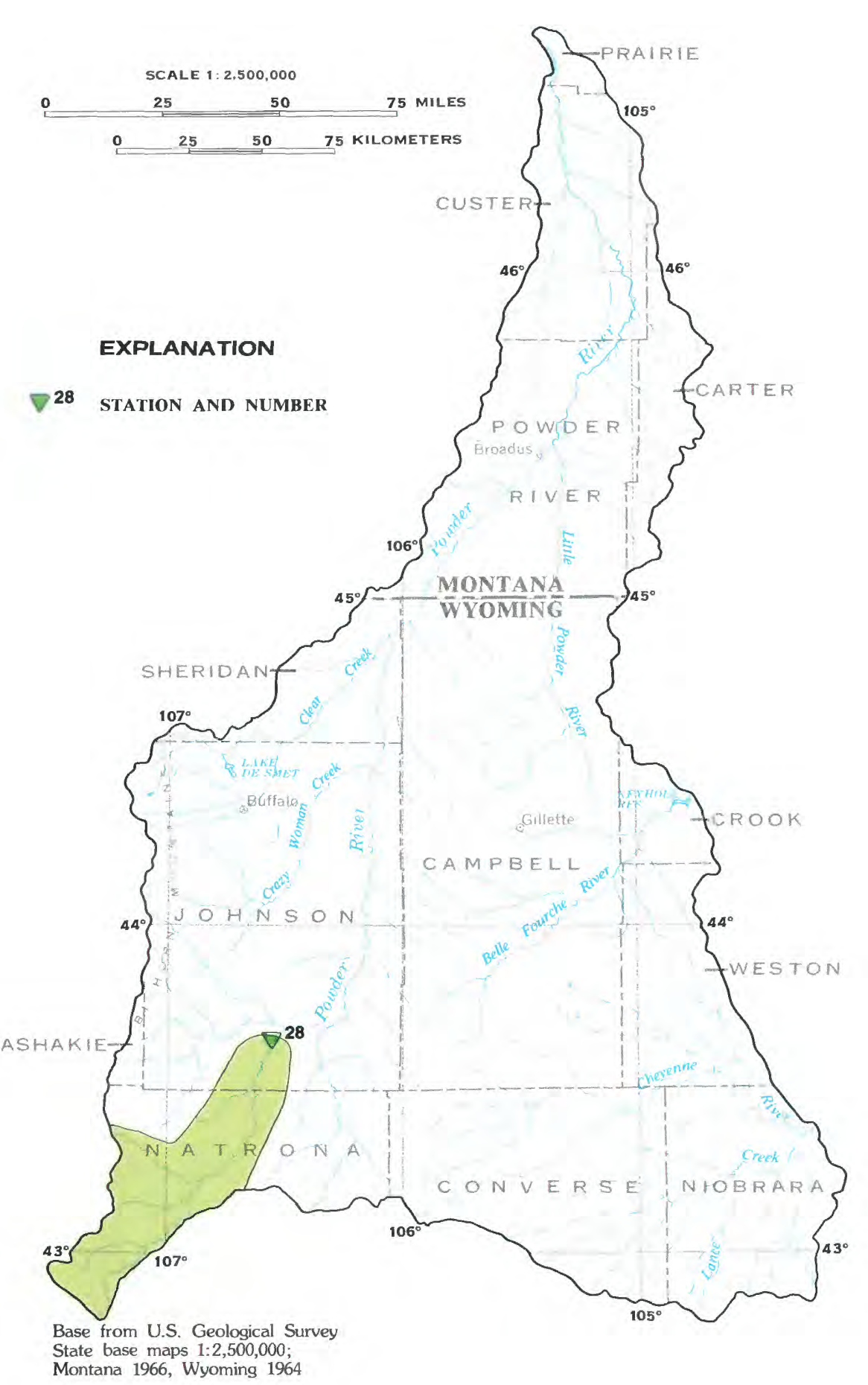

Figure 7.1.7-1 Drainage basin upstream from station 28, where selenium concentrations generally exceed 10 micrograms per liter.
Table 7.1.7-1 Dissolved-trace metal concentrations in the streams of the area.

\begin{tabular}{lcccccc}
\hline & $\begin{array}{c}\text { Number } \\
\text { of analyses } \\
\text { exceeding } \\
\text { drinking- } \\
\text { water } \\
\text { standards }\end{array}$ & $\begin{array}{c}\text { Percent of } \\
\text { analyses } \\
\text { exceeding } \\
\text { drinking- } \\
\text { water } \\
\text { Dissolved- } \\
\text { trace metal }\end{array}$ & $\begin{array}{c}\text { Drinking- } \\
\text { water } \\
\text { standard } \\
\text { (micrograms } \\
\text { per liter) }\end{array}$ & $\begin{array}{c}\text { Median } \\
\text { value } \\
\text { (micrograms } \\
\text { per liter) }\end{array}$ & $\begin{array}{c}\text { Maximum } \\
\text { value } \\
\text { (micrograms } \\
\text { per liter) }\end{array}$ & $\begin{array}{c}\text { Number } \\
\text { of } \\
\text { analyses }\end{array}$ \\
\hline Arsenic & 0 & 0 & 150 & 1 & 50 & 373 \\
Barium & 0 & 0 & 11,000 & 100 & 400 & 140 \\
Cadmium & 5 & 1.4 & 10 & 2 & 20 & 370 \\
Chromium & 0 & 0 & 150 & 0 & 20 & 374 \\
Copper & 0 & 0 & 21,000 & 3 & 70 & 397 \\
Iron & 45 & 3.4 & 2300 & 40 & 1,800 & 1,316 \\
Lead & 5 & 1.1 & 150 & 2 & 200 & 370 \\
Manganese & 256 & 55.8 & 250 & 70 & 6,600 & 459 \\
Mercury & 4 & 1.1 & 12 & 0.1 & 4.0 & 380 \\
Selenium & 8 & 2.1 & 110 & 1 & 26 & 381 \\
Zinc & 0 & 0 & 25,000 & 20 & 180 & 382 \\
\hline
\end{tabular}

${ }_{2}^{1}$ National interim primary drinking-water standards (U.S. Environmental Protection Agency, 1977) 2 National secondary drinking-water regulations (U.S. Environmental Protection Agency, 1979) 


\subsection{SURFACE-WATER QUALITY--Continued \\ 7.2 Suspended Sediment \\ 7.2.1 Cuncentration}

\section{Suspended-Sediment Concentrations Much Larger During High Flows}

\section{Larger concentrations of suspended sediment during high flow are the result of increased energy of flowing water, larger area of streambanks being inundated, and greater vulnerability of soil to erosion by rainfall or snowmelt.}

Concentrations of suspended sediment in streams vary directly with streamflow---small concentrations generally are associated with low flows and large concentrations are associated with high flows. The relation between suspended-sediment concentration and water discharge for the Powder River at Arvada, Wyo. is illustrated in figure 7.2.1-1. This relation differs somewhat among datacollection stations, but in all instances within Area 50 the trend towards increasing concentrations for increasing discharges is similar.

Annual discharge-weighted concentrations are shown in figure 7.2.1-2 for four groups of stations: (1) On the Powder River, (2) on streams tributary to the Powder River, (3) on the Belle Fourche River, and (4) on the Cheyenne River. These graphs compare concentrations for an extreme flood year, 1978, with the average of two subsequent years, 1979-80, when flows were substantially smaller. The lack of 1978 data at some stations is noted on the graphs.

The quantity of sediment in transport can be computed from sediment concentration and discharge by using the formula,

$$
\mathrm{Q}_{\mathrm{S}}=0.0027 \mathrm{Q}_{\mathrm{W}} \times \mathrm{C}_{\mathrm{S}},
$$

where $\mathrm{Q}_{\mathrm{S}}=$ sediment discharge, in tons per day; $\mathrm{Q}_{\mathrm{w}}$ $=$ water discharge, in cubic feet per second; $\mathrm{C}_{\mathrm{s}}=$ suspended-sediment concentration, in milligrams per liter; and 0.0027 is a conversion coefficient.

Suspended sediment is the major cause of turbidity. Excessive turbidity blocks sunlight that aquatic plants need for photosynthesis (the synthesis of carbohydrates from water and carbon dioxide in the presence of light). Large quantities of fine sediment can clog the gills of invertebrates and fish. Deposition of fine sediment in voids between sand and gravel particles destroys habitat for invertebrates and fish eggs. Excessive turbidity also decreases the esthetic quality of the water.

Suspended-sediment particles provide the surface onto which moderately soluble chemicals in water may sorb and be transported. Thus, chemically enriched sinks can form in sediment deposition areas. Sediment also provides a substrate on which aqueous chemical reactions can take place. The presence of suspended sediment in a flowing stream also limits the capability of that stream to acquire and transport additional sediment. Conversely, a reduction of sediment (particularly in a stream that previously transported large amounts of sediment) enhances the capability of that stream to acquire and transport additional sediment.

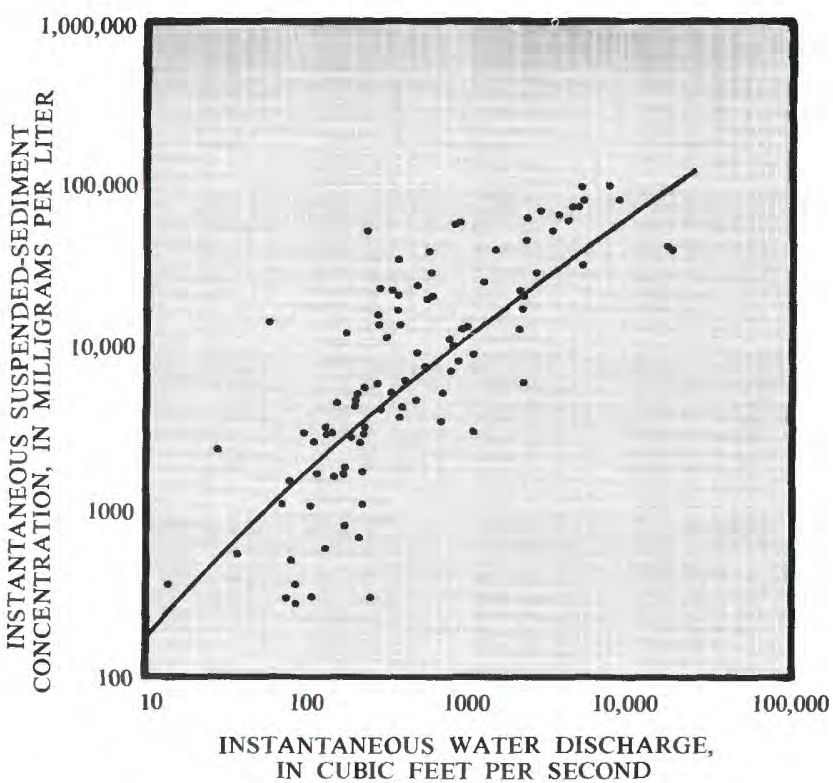

Figure 7.2.1-1 Relation between suspended-sediment concentration and water discharge for Powder River at Arvada, Wyoming (station 63). 

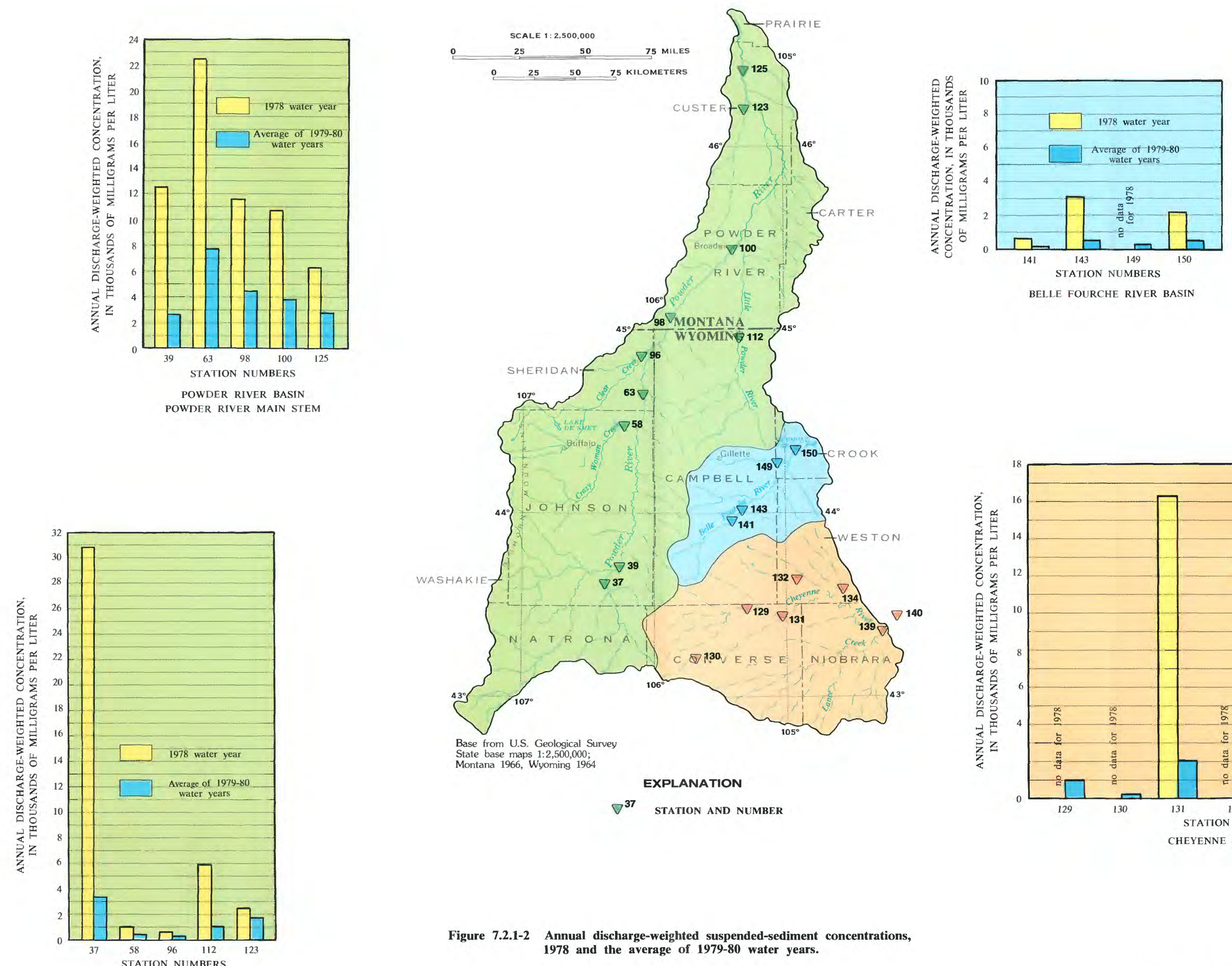

STA

POWDER RIVER BASIN
TRIBUTARIES TO POWDER RIVER Figure 7.2.1-2 Annual discharge-weighted suspended-sediment concentrations,
1978 and the average of 1979-80 water years.

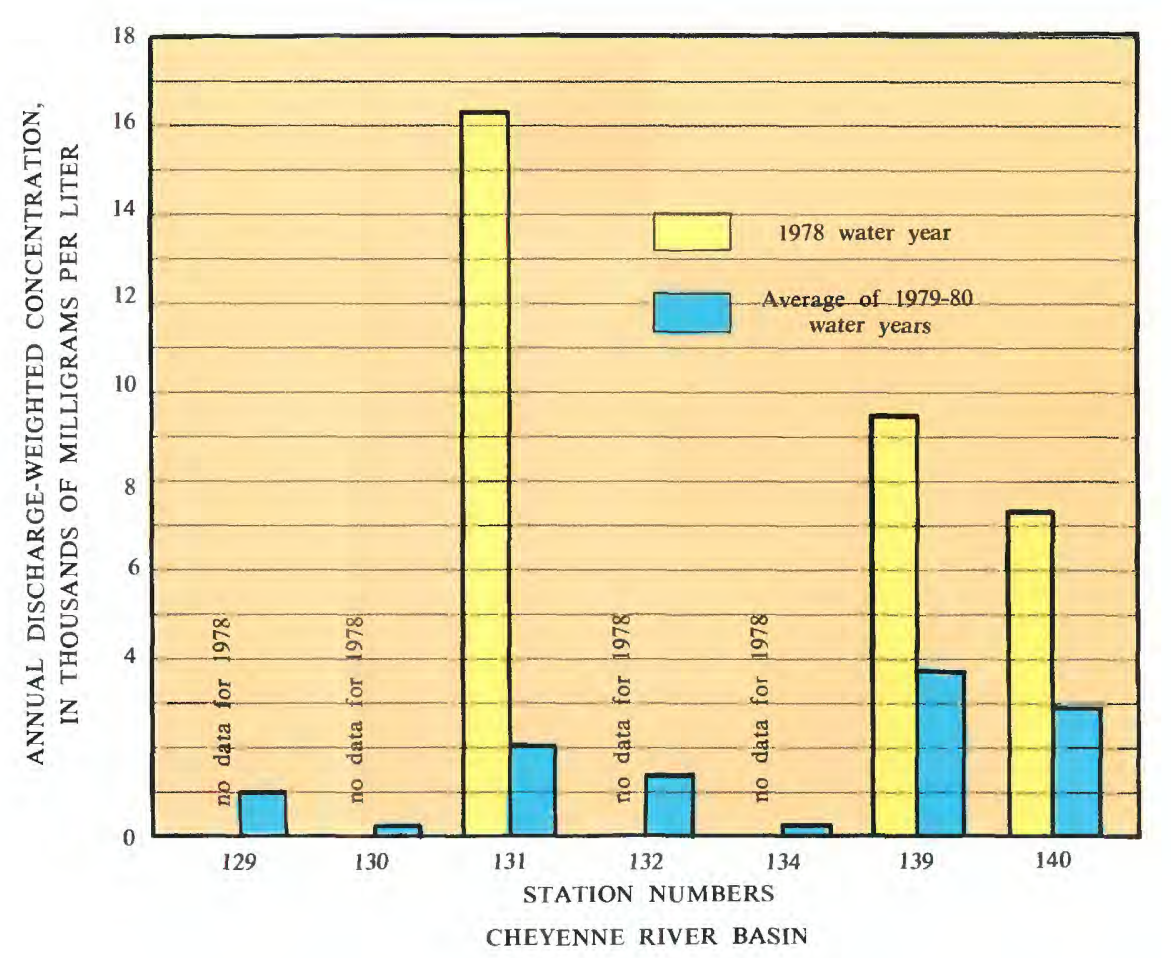




\title{
7.0 SURFACE-WATER QUALITY--Continued \\ 7.2 Suspended Sediment--Continued \\ 7.2.2 Loads--Powder River
}

\section{Sediment Load in Powder River is Mostly from Wyoming}

\author{
Sediment loads transported by the Powder River are large, are eroded mostly \\ from the Wyoming reach, and are partly deposited in the Montana reach.
}

\begin{abstract}
"Too thick to drink and too thin to plow." This very early description of the Powder River is appropriate, because at times the streamflow consists of a mixture that is 10 percent sediment and 90 percent water.
\end{abstract}

Records of suspended-sediment load obtained at five data-collection stations on the main channel and at one station on each of its five main tributaries (fig. $7.2 .2-1)$ are given in table 7.2.2-1. The average (24 years) amount of suspended sediment transported past Arvada, Wyo. (station 63) is 4,710,000 tons per year, which is the equivalent of 129 railroad carloads each day, each car transporting 100 tons. On the average, only $2,700,000$ tons per year are transported past Locate, Mont. (station 125), indicating that about 2,010,00 tons per year are deposited in the reach between Arvada and Locate. This hypothesis is supported by Martinson (1982) who surveyed cross sections of the river between Moorhead (station 98) and Broadus (station 100) and found that the stream channel was aggrading. Martinson and Meade (1983) documented changes in the river channel between
Moorhead and Broadus during the period, 1938-78. This same effect--scour, or increasing loads, in the upstream reach of a large river and deposition, or decreasing loads, in the downstream reach--was noted for the Yellow River in China (Long and Xiong, 1981). The graph of variation in loads along the Powder River (fig. 7.2.2-2) illustrates that this hypothesis also must be true for the reach between Arvada (station 63) and Moorhead (station 98). The rate of deposition in that reach probably is greater than that between Moorhead and Broadus. The contribution of suspended sediment from the five main tributaries represents 8 percent of the load in the main stream during years of low flow and 16 percent during years of high flow.

Photographs of the Powder River in the vicinity of Arvada, Wyo., following the major flood of May 18-22, 1978 are shown in figures 7.2.2-3 and 7.2.2-4. Scour into a road by the river is shown in figure 7.2.2-3 and deposition resulting from river overflow onto the flood plains is shown in figure 7.2.2-4. 


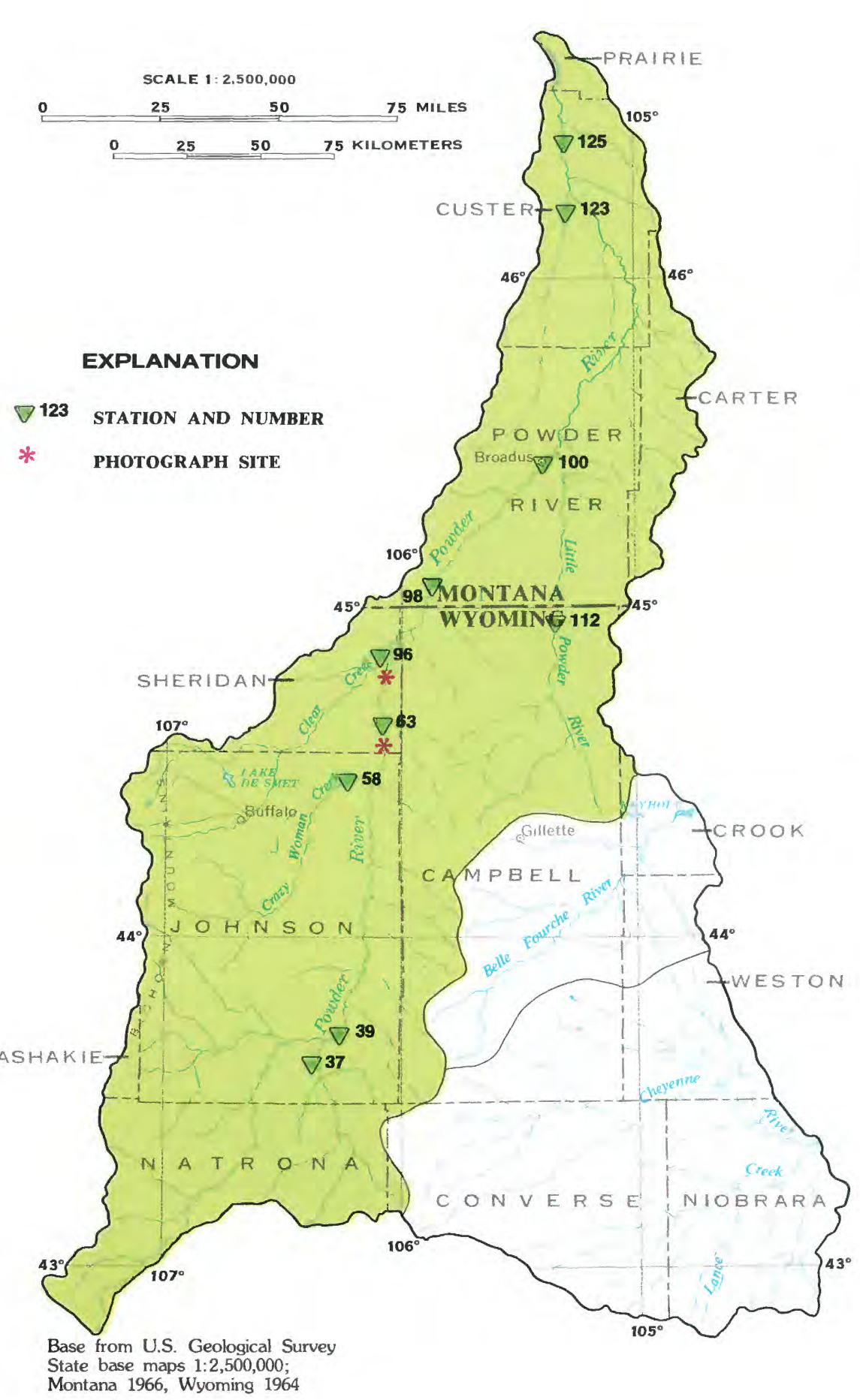

Figure 7.2.2-1 Location of suspended-sediment stations in the Powder River Basin.

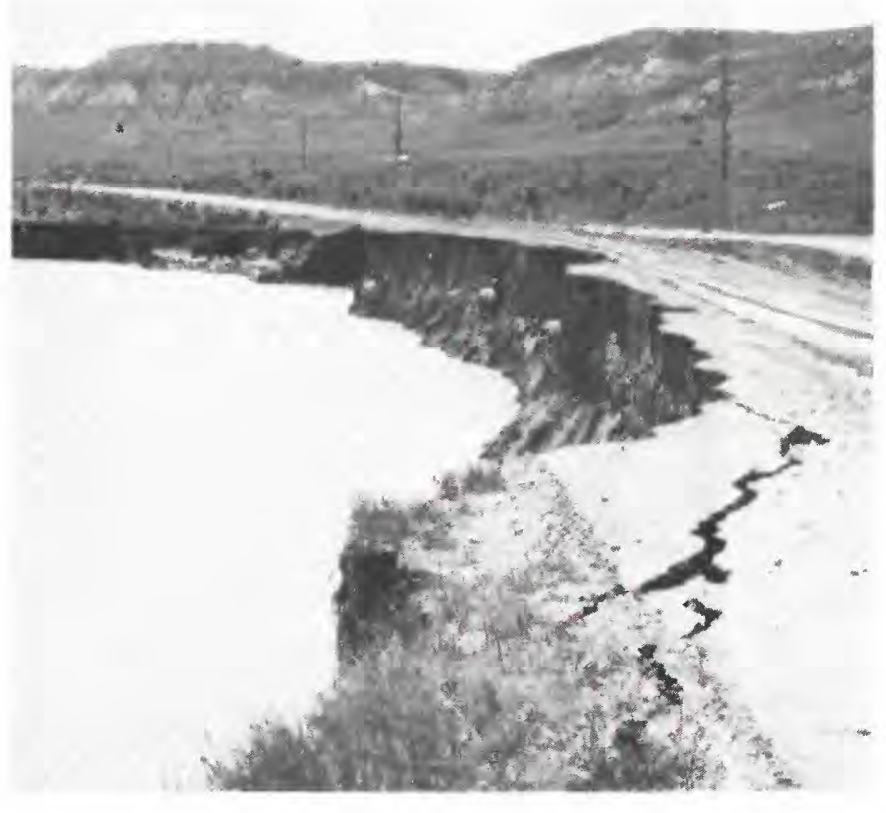

Figure 7.2.2-3 Eroded bank at bend in the Powder River near Arvada, Wyoming, after flood of May 1978.
norre

Table 7.2.2-1 Annual suspended-sediment
loads, in tons. loads, in tons.

\begin{tabular}{crr}
\hline $\begin{array}{c}\text { Station } \\
\text { number }\end{array}$ & $\begin{array}{c}1978 \\
\text { water year }\end{array}$ & $\begin{array}{c}\text { Average of } \\
1979-80 \\
\text { water years }\end{array}$ \\
\hline \multicolumn{3}{c}{$\begin{array}{c}\text { Powder River } \\
\text { Pasin }\end{array}$} \\
\cline { 2 - 3 } 37 & $2,521,000$ & \multicolumn{1}{c}{130,000} \\
39 & $5,996,000$ & 492,000 \\
58 & 109,000 & 11,200 \\
163 & $16,270,000$ & $1,786,000$ \\
96 & 159,000 & 5,780 \\
98 & $12,490,000$ & $1,235,000$ \\
100 & $11,720,000$ & $1,128,000$ \\
112 & 715,000 & 7,340 \\
123 & 104,000 & 22,300 \\
125 & $9,200,000$ & $1,000,000$ \\
\hline
\end{tabular}

124 -year average is $4,710,000$ tons
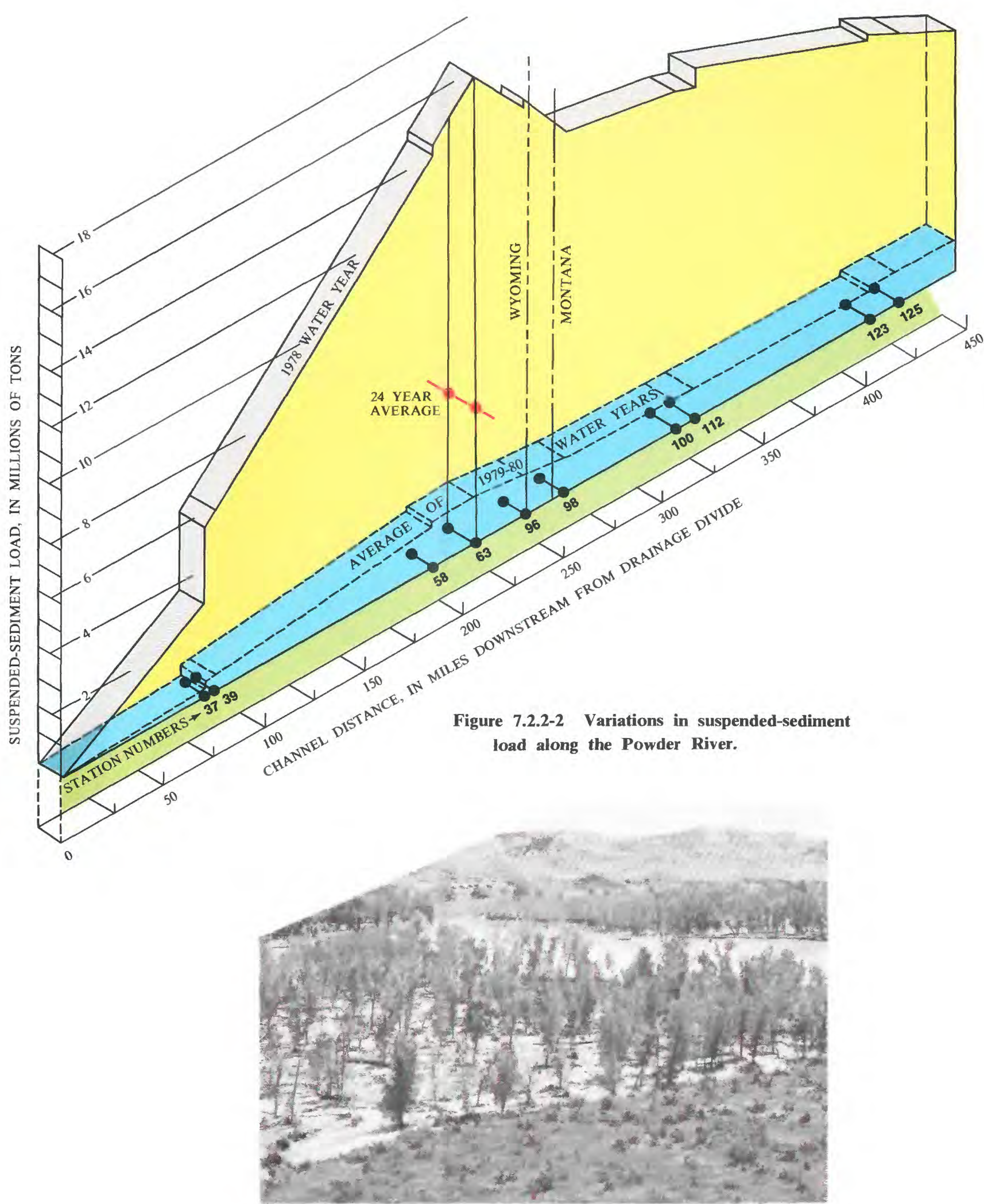

Figure 7.2.2-4 Deposition on flood plain of Powder River about 15 miles downstream from Arvada, Wyoming.

7.0 SURFACE-WATER QUALITY--Continued 7.2 Suspended Sediment--Continued
7.2.2 Loads--Powder River 


\title{
7.0 SURFACE-WATER OUALITY--Continued \\ 7.2 Suspended Sediment--Continued \\ 7.2.3 Loads--Belle Fourche and Cheyenne Rivers
}

\section{Sediment Loads in Belle Fourche and Cheyenne Rivers Increase Downstream}

\author{
Sediment loads transported by the Belle Fourche and Cheyenne Rivers are \\ significantly less than loads transported by the Powder River; sediment \\ is trapped in Keyhole Reservoir on the Belle Fourche River and in \\ Angostura Reservoir on the Cheyenne River.
}

The quantity of sediment transported by a stream is directly related to the quantity of water discharged by that stream. Because the quantity of water in the Belle Fourche and Cheyenne Rivers is less than that in the Powder River, the sediment loads measured at stations shown in figure 7.2.3-1 are significantly less than that transported by the Powder River (section 7.2.2). The sediment loads transported by the Belle Fourche and Cheyenne Rivers increase downstream (fig. 7.2.3-2) in a manner similar to the increase in the upstream reach of the Powder River (section 7.2.2).

The average loads transported by the Belle Fourche and Cheyenne Rivers during the 1979-80 water years are listed table 7.2.3-1. The flow during 1979 and 1980 was significantly less than the longterm average; hence, the loads transported during these years also were less than the estimated 26-year average.

Sediment discharged from the drainage basin of the Belle Fourche River upstream from Keyhole Reservoir and that from the area contiguous to the reservoir are trapped in the reservoir. Sediment discharged from the Cheyenne River basin in Area 50 is trapped in Angostura Reservoir (located on-channel, about 60 river miles downstream from the edge of Area 50). 


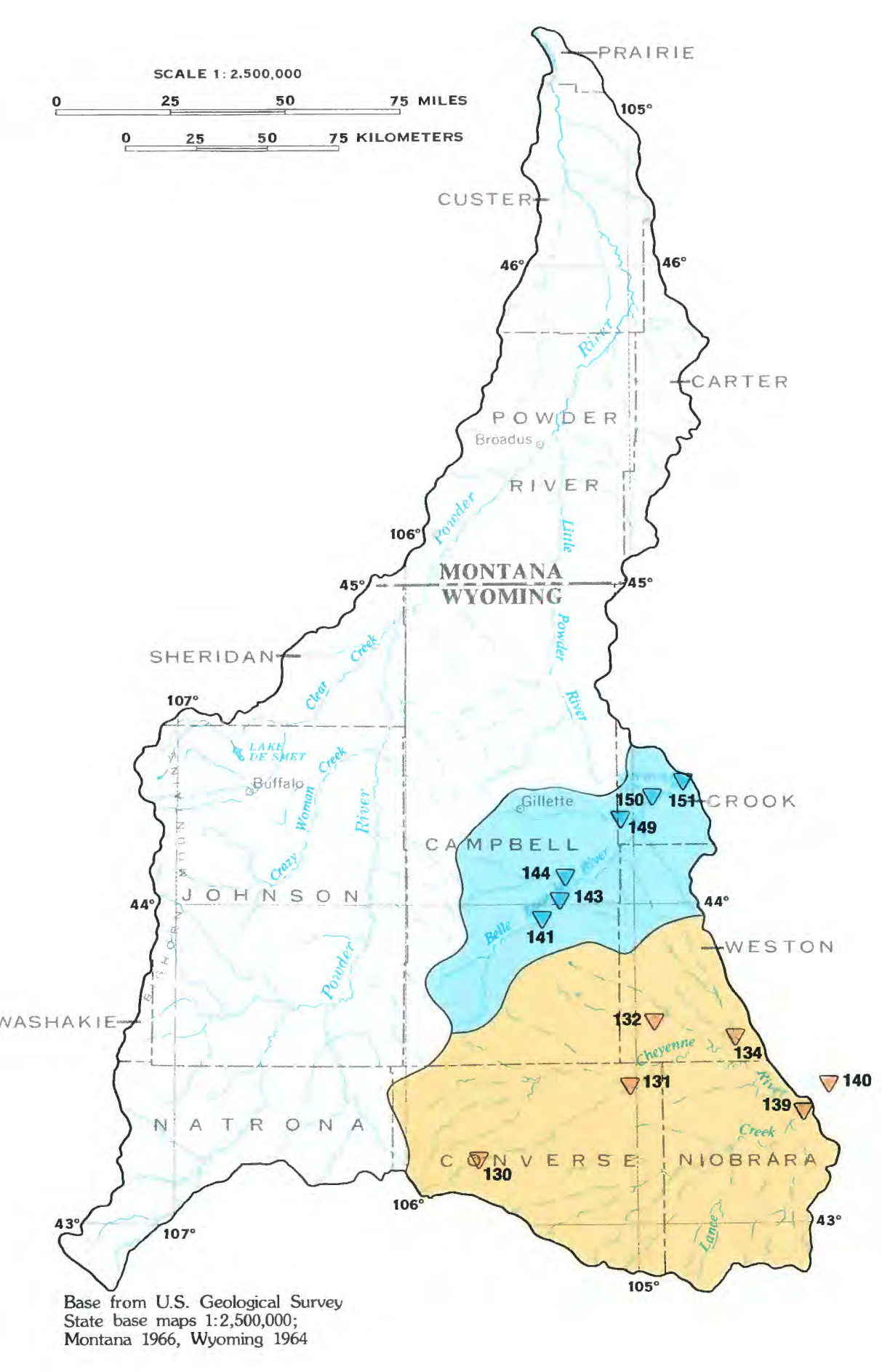
Figure 7.2.3-1 Location of suspended-sediment stations

\begin{tabular}{|c|c|c|}
\hline $\begin{array}{l}\text { Station } \\
\text { number }\end{array}$ & $\begin{array}{c}\text { Average of } \\
1979-80 \\
\text { water years }\end{array}$ & $\begin{array}{l}26 \text {-year } \\
\text { average }\end{array}$ \\
\hline & \multicolumn{2}{|c|}{ Belle Fourche River } \\
\hline 141 & 265 & -- \\
\hline 143 & 1,240 & -- \\
\hline 144 & $\begin{array}{l}192 \\
674\end{array}$ & -- \\
\hline 149 & $\begin{array}{r}674 \\
8.230\end{array}$ & 49.300 \\
\hline \multirow{2}{*}{151} & $\begin{array}{r}8,230 \\
42,700\end{array}$ & $\begin{array}{l}49,500 \\
256,000\end{array}$ \\
\hline & Cheyenne River & \\
\hline 130 & 101 & -- \\
\hline 131 & 17,300 & -- \\
\hline 133 & 2,190 & -- \\
\hline 134 & 133 & -- \\
\hline 139 & 102,000 & 235,000 \\
\hline 140 & 294,000 & $1,220,000$ \\
\hline
\end{tabular}

\section{EXPLANATION}

$\nabla 143$ STATION AND NUMBER

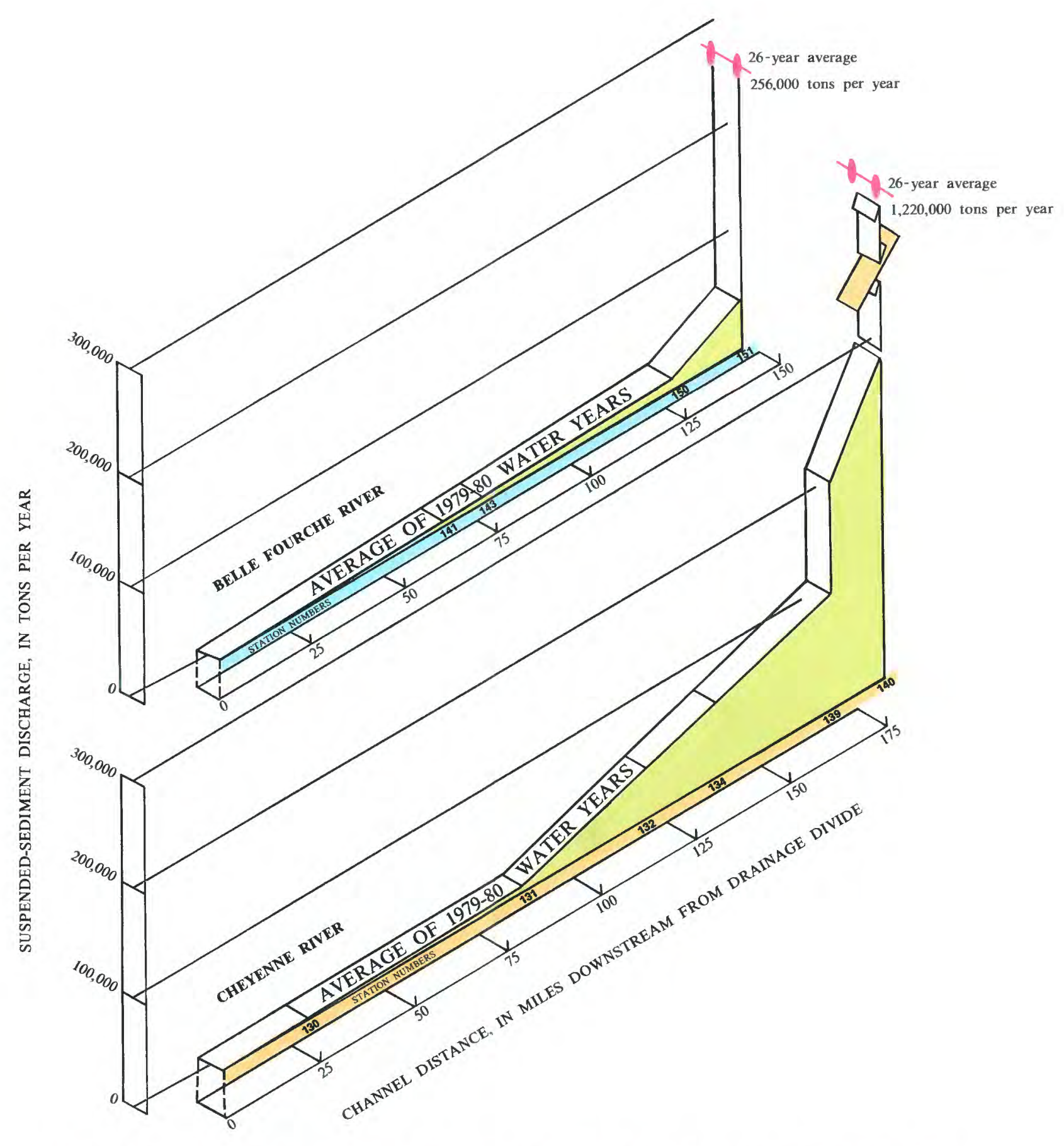

Figure 7.2.3-2 Variations in suspended-sediment load along the Belle Fourche and Cheyenne Rivers. 


\subsection{SURFACE-WATER OUALITY--Continued \\ 7.2 Suspended Sediment--Continued \\ 7.2.4 Particle Size}

\section{Suspended Sediment is Mostly Clay}

\section{Clay-size particles comprise between 38 and 97 percent of the sediment transported out of Area 50; an average of less than 8 percent is sand.}

Silt and clay comprise an average of 89 percent of the suspended sediment transported in streams of the Powder River Basin, 94 percent in the Belle Fourche, and 97 percent in the Cheyenne River basin. These values are unweighted averages from all samples (table 7.2.4-1) analyzed during the period of record at each station shown in figure 7.2.4-1. Further analysis of available data indicates that clay composes 58 percent of the suspended sediment in transport in the Powder River Basin, 77 percent in the Belle Fourche River basin, and 80 percent in the Cheyenne River basin.

Computation of the volume occupied by sediment deposited by a stream requires knowledge of the size distribution of the sediment. The location of deposition within the streambed or reservoir and determination of hydraulic characteristics of that deposit may be inferred from particle-size data. Information regarding sediment sources and the flow characteristics of the stream also may be obtained.

Particle sizes in deposits tend to become more uniform as median particle size decreases; therefore, deposits of material where sediment particles are about clay-size generally have greater porosity and smaller initial specific weight than deposits composed mostly of sand sizes. A clay deposit also will generally occupy a larger volume per given weight of material than will a sand deposit. The number of suspended-sediment samples for each sampling station for which particle-size distributions, the average composition of the samples, and the specific weight of a deposit of that composition were determined are listed in table 7.2.4-1. 


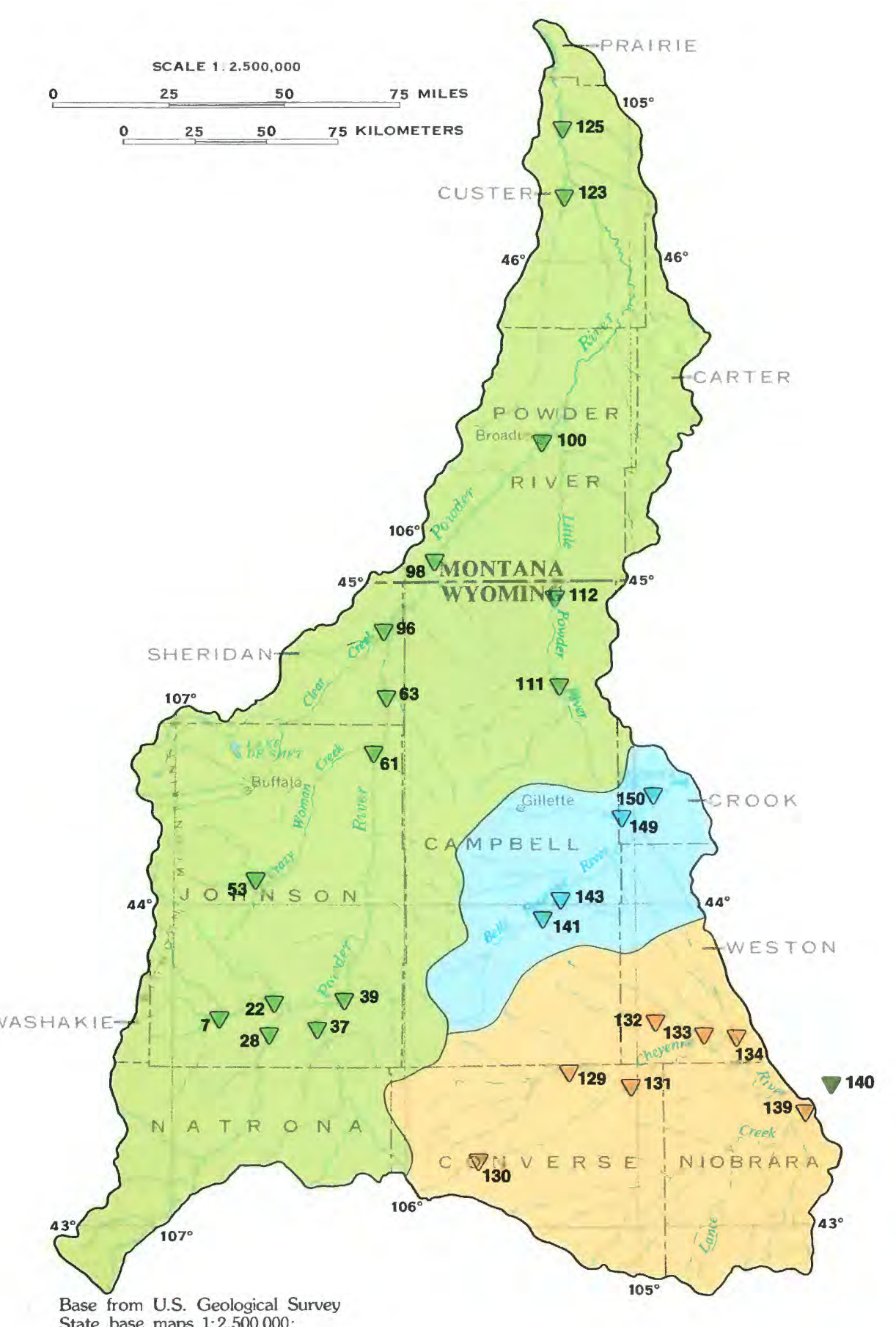

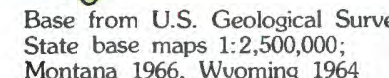

Figure 7.2.4-1 Size distribution of fluvial sediment.
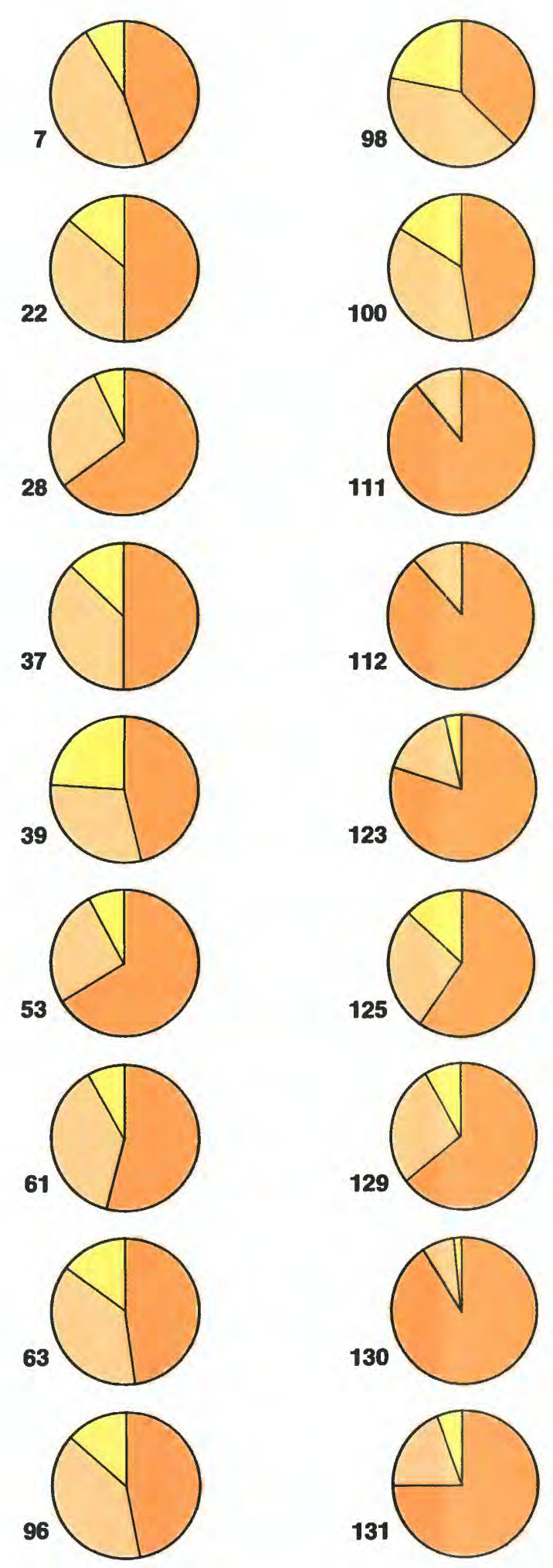
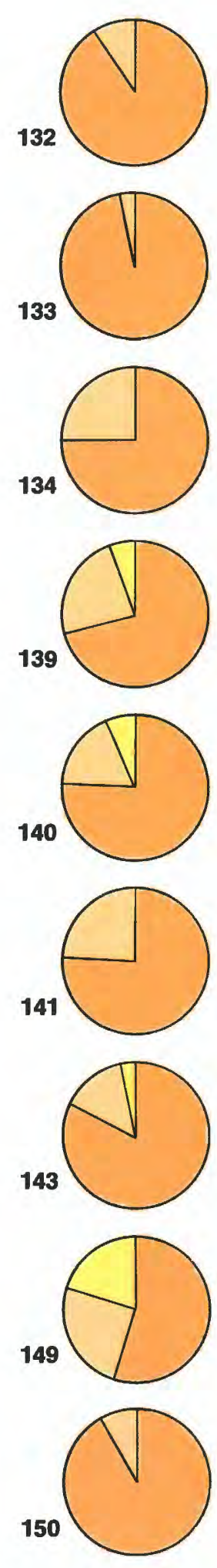

Table 7.2.4-1 Size distribution and specific weight of fluvial sediment.

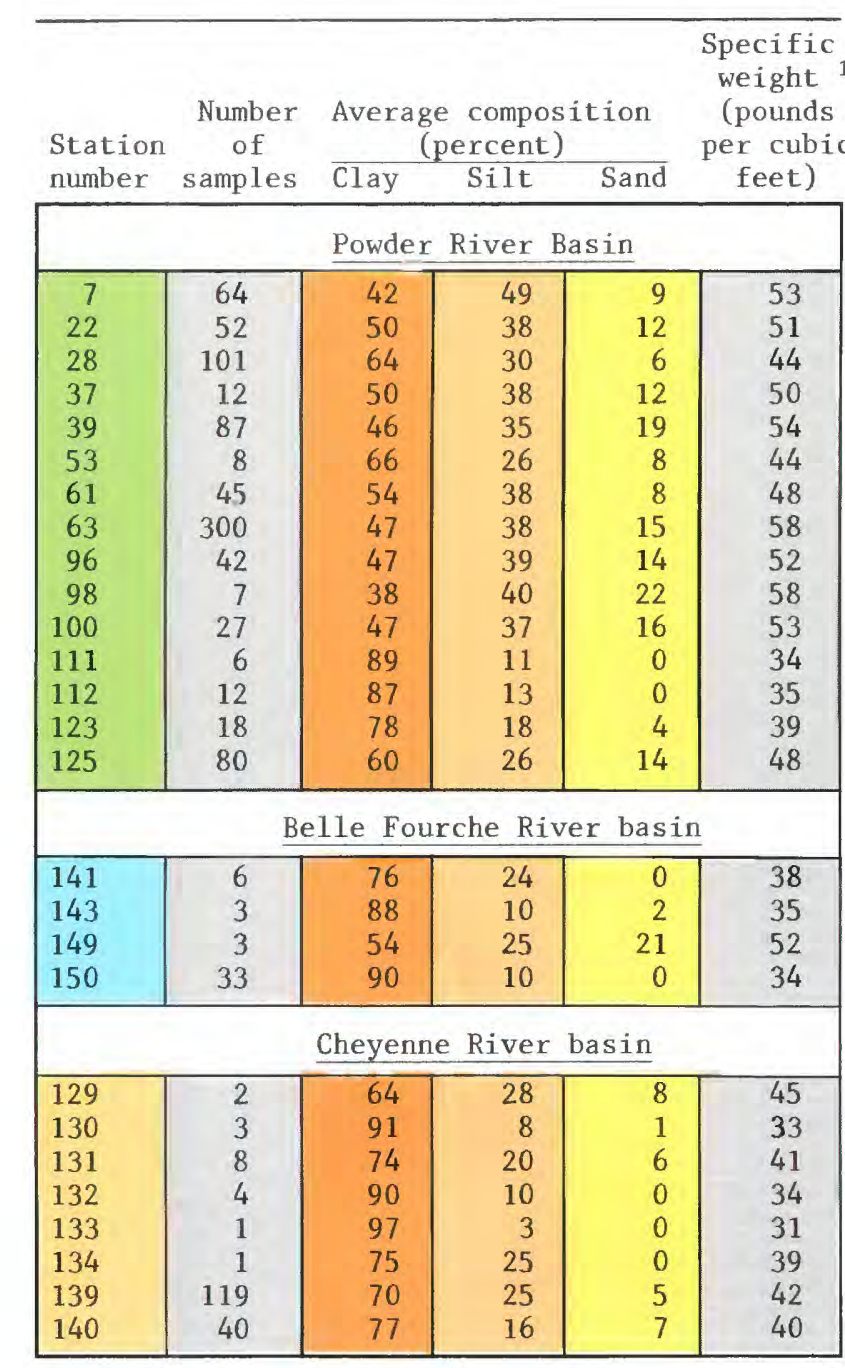

1 Based on average composition

\section{EXPLANATION}

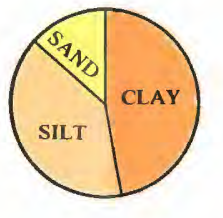

Sitt-0.004 to 0.062 millimeter
Particle SIZE based on Diameter

Sand-Coarser than 0.062 millimeter

Clay-Finer than 0.004 millimeter

$\nabla^{39} \quad$ STATION AND NUMBER 


\title{
7.0 SURFACE-WATER QUALITY--Continued \\ 7.3 Biology \\ 7.3.1. Bacteria
}

\section{Bacteria Concentrations are Small Throughout Area}

\author{
Small concentrations of fecal coliform and fecal streptococci bacteria indicate \\ little pollution from warm-blooded animals.
}

The median value of fecal coliform bacteria did not exceed 600 colonies per 100 milliliters of water, and the median value of fecal streptococci bacteria did not exceed 400 colonies per 100 milliliters at the stations shown in figure 7.3.1-1. The median value is the value for which 50 percent of the sample values are greater and 50 percent are smaller.

The two primary sources of fecal bacteria in Area 50 are fecal waste from livestock and wildlife, and human waste from sewage plants or individual septic systems. Because there are relatively few people and livestock in the area, fecal pollution contributed to streams by humans and animals is small. The probable sources of fecal bacteria at most stations are fecal wastes of livestock and wildlife that graze in the area and drink from streams.

Fecal coliform and fecal streptococci bacteria originate in the gastrointestinal tract of warmblooded animals, and are not adapted to aquatic environments. Their presence does not constitute a health hazard; they are sampled as indicators of the possible presence of pathogens, or disease-causing organisms. The half-life (length of time during which one-half of the remaining bacteria are destroyed) of fecal coliform and fecal streptococci bacteria outside the gastrointestinal tract is about 24 hours (Mallard, 1981). Therefore, the bacteria measured in samples were deposited a relatively short time prior to sampling. The distance of the sample bacteria from their source is dependent on the time of travel of the water in the stream.

Bacteria concentrations in the streams of the area will be affected to a greater degree by the population increase associated with increased mining of coal and other energy minerals than by the mining itself. Owing to the short life-span of the bacteria and the ephemeral flow of many of the streams, increased sewage effluent in streams will cause local, rather than regional, increases in bacteria concentrations. There is a demand for the sewage effluent of Gillette for industrial uses and by the local ranchers for irrigation. 


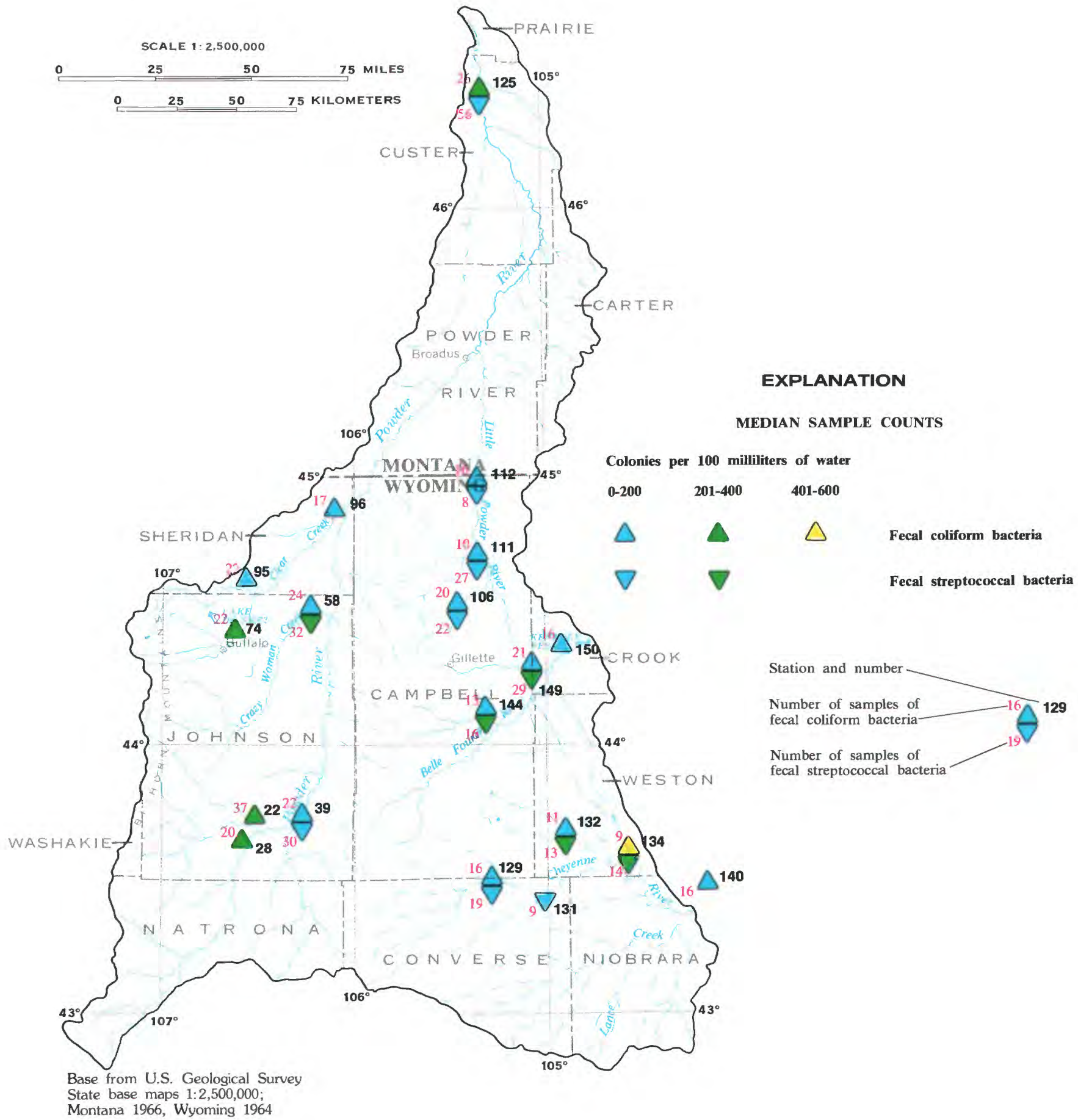

Figure 7.3.1-1 Fecal coliform and fecal streptococcal bacteria concentrations. 


\title{
7.0 SURFACE-WATER QUALITY--Continued 7.3 Biology--Continued \\ 7.3.2 Algae
}

\section{Algae are Indicators of Water Quality}

\author{
The productivity and relative abundance of diatoms, green algae, blue-green \\ algae, and euglenoids within the periphyton and phytoplankton communities \\ indicate organic enrichment in many streams of the area.
}

Diatoms are a common algae in periphyton and phytoplankton communities of the area, and commonly dominate the communities of perennial streams. Green algae, blue-green algae, and euglenoids commonly dominate the periphyton and phytoplankton communities of ephemeral and intermittent streams and perennial streams that receive sewage effluent from towns. Dominance of an algal community by green and blue-green algae or euglenoids generally is considered to be a sign of organic enrichment, particularly nutrients, whereas a relatively diverse diatom community generally predominates in unenriched environments. Because few of the streams in the area receive sewage effluent, the commonness of green and blue-green algae, and euglenoids probably is a result of the natural environmental conditions and fecal waste from livestock and wildlife. The location of stations sampled for phytoplankton (algae suspended in the water) and periphyton (algae attached to objects, such as rocks and logs) is shown in figure 7.3.2-1.

Phytoplankton concentrations in samples from two sites, one on an ephemeral stream reach and one on a perennial stream reach, are indicated in figure 7.3.2-2. The ephemeral stream reach contains stagnant pools that serve as waterholes for livestock; the perennial stream reach also receives livestock use, but the effects are diluted by the flowing water. Nutrients contributed by the livestock stimulate algal growth, particularly the growth of green and blue-green algae, and euglenoids.

The types or concentrations of algae in periphyton and phytoplankton communities could be affected by coal mining through changes in water quality or quantity. In a study of streams in southeastern Montana, Bahls (1980) found that salinity (as indicated by specific-conductance values of less than 6,400 micromhos) did not appear to adversely affect periphyton community structure; he also identified previous work (Bahls, 1979) that showed negative effects on diatom diversity from salinity (as indicated by specific-conductance values in excess of 7,500 micromhos). It is important to know how coal mining might affect algae, because algae are at the base of the aquatic food chain. Through photosynthesis, algae are the primary producers. Algae are a part of the diet of many fish; algae also serve as food for animals, such as insects in streams or zooplankton in lakes, which in turn are food for larger animals, such as fish. 

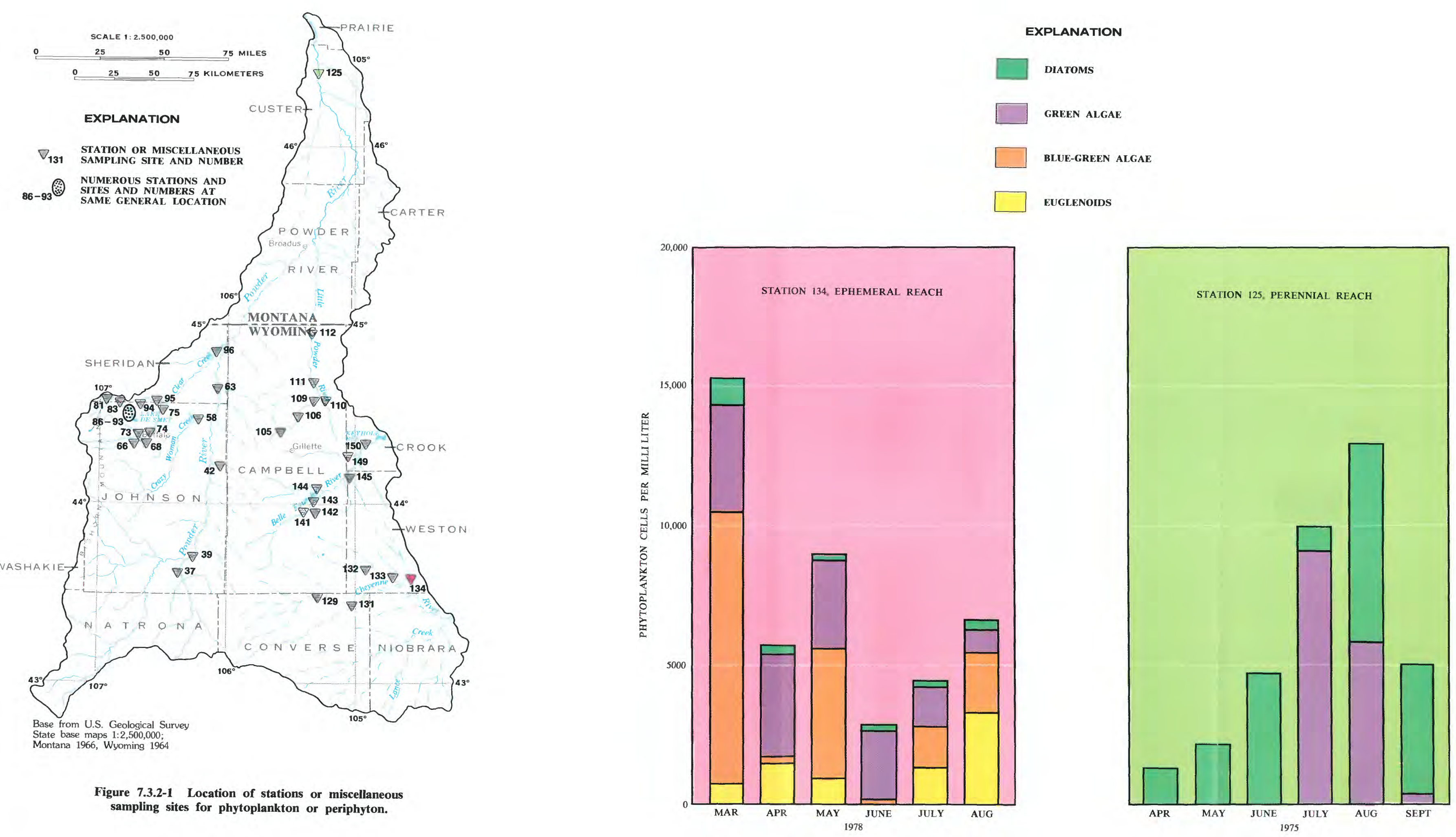

Figure 7.3.2-2 Phytoplankton counts for selected samples from an ephemeral reach of 


\author{
7.0 SURFACE-WATER QUALITY--Continued \\ 7.3 Biology--Continued \\ 7.3.3 Invertebrates
}

\title{
Invertebrate Communities are Indicators of Water Quality and Quantity
}

\author{
The invertebrate communities of streams receiving sewage effluent are different \\ from the communities of other streams; the invertebrate communities inhabiting \\ ephemeral streams are different from those of perennial and intermittent streams.
}

The invertebrate communities of Clear Creek and Donkey Creek reflect degradation of water quality by inflow of sewage effluent. Two invertebrate taxa (Tubificid worms and Chironomid bloodworms) that adapt to oxygen-deficient, organically enriched environments dominated invertebrate samples collected at site 158 on Donkey Creek. The invertebrate community composition in Clear Creek downstream from a sewage treatment plant (sites 165-168) was different from that upstream (sites 160-163), but the differences were less pronounced than for Donkey Creek because of dilution of the sewage by Clear Creek. The locations of invertebrate sampling stations and sites are shown in figure 7.3.3-1.

The invertebrate communities of streams in the area can be used as indicators of the water quantitythe relative volume and pattern of flow. The communities inhabiting ephemeral streams are adapted to life in lentic (standing water) habitats, such as pools. The body structure, feeding habits, and respiratory system of invertebrates adapted to lentic habitats are different from those of invertebrates adapted to life in lotic (flowing water) habitats, such as riffles in perennial or intermittent streams. Invertebrates adapted to lentic habitats can survive in the pools of perennial or intermittent streams, but invertebrates adapted to lotic habitats have a large mortality rate in lentic habitats.

Densities and community composition of invertebrates upstream and downstream from a coal mine are shown in figure 7.3.3-2. Although not tested statistically, the density and diversity of the invertebrate community generally appear to be at least as large downstream from the mine as upstream. Between the stations, the stream receives intermittent flow from a tributary, is diverted around the mine, and receives infrequent discharge pumped from the mine pit. Any one or a combination of these actions may have an effect on the invertebrate communities at the station downstream from the mine. The communities at either station are not atypical of communities in lentic habitats in other streams of the area.

In contrast to coal areas in the eastern United Sates, mine pumpage or leachate from coal mines in Area 50 generally does not contain toxic compounds in concentrations large enough to be lethal to invertebrates. Wangsness (1977) and Rockett (1976) found that invertebrate communities had developed in strip-mine ponds during the 20 to 30 years after they had been abandoned, but some differences still existed between the communities of natural ponds in the area and those of the abandoned mine ponds.

The invertebrate communities of small streams within or near Area 50 have been studied by Baril and others (1978), Wesche and Johnson (1980), and Wangsness and Peterson (1980). A photograph of an invertebrate, a caddisfly larva, from a small stream is shown in figure 7.3.3-3. Rehwinkel (1978) noted that invertebrates are not abundant in the Powder River in Montana. 


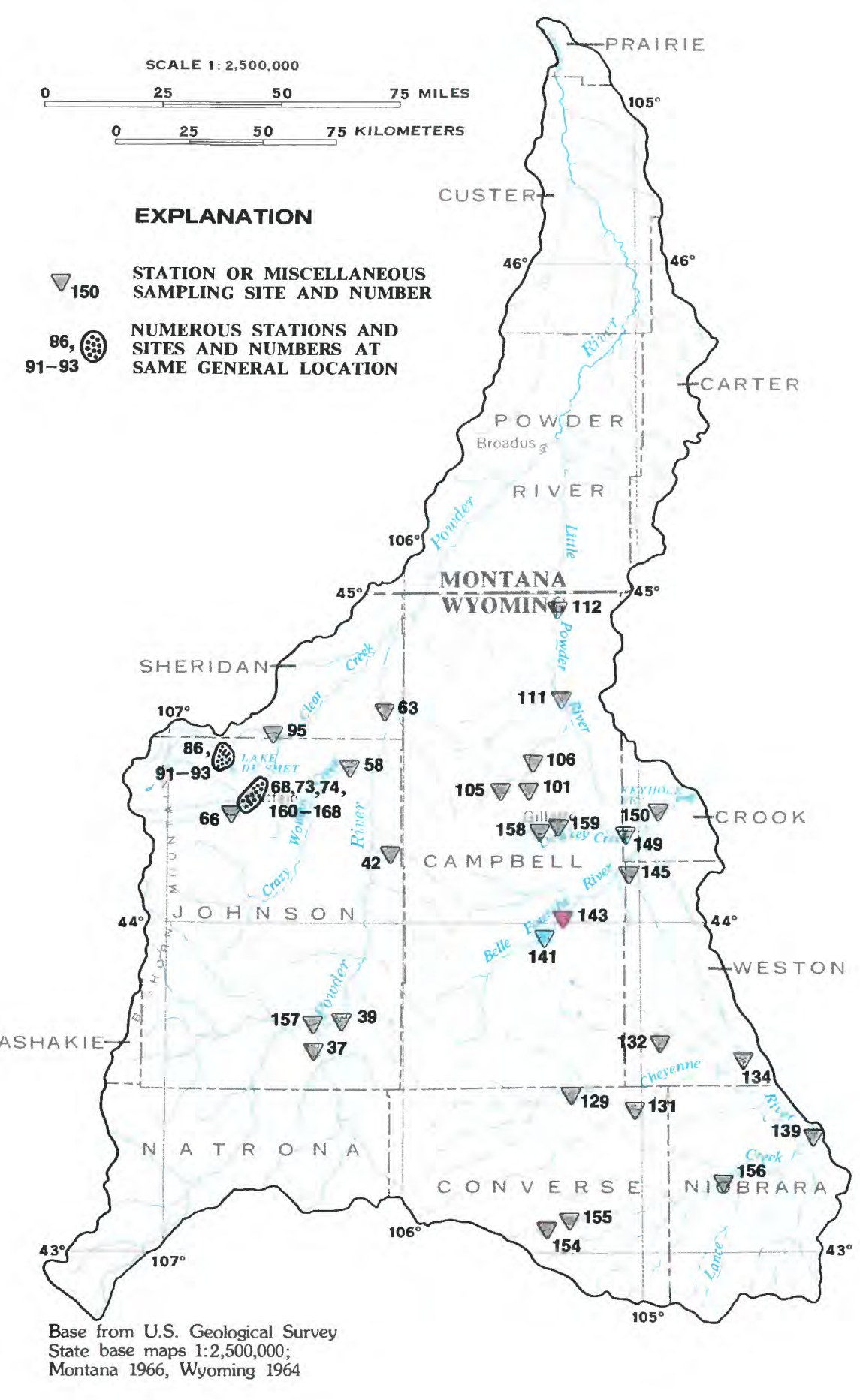

Figure 7.3.3-1 Location of stations or miscellaneous sampling sites for invertebrates.

\section{EXPLANATION}

$\square$ DIPTERA

$\square$ EPHEMEROPTERA

CRUSTACEA

$\square$ OTHERS
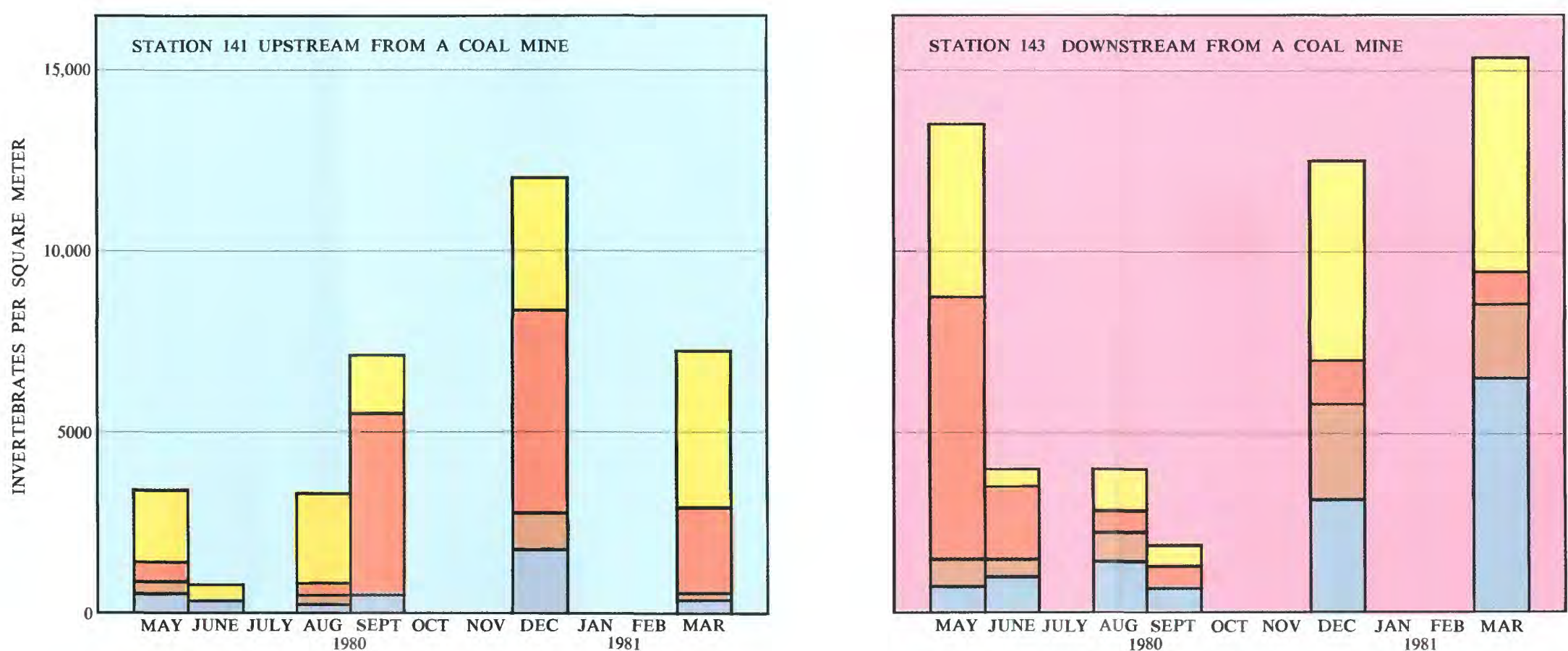

Figure 7.3.3-2 Invertebrate densities and community compositions of two ephemeral stream reaches of the Belle Fourche River. 


\author{
7.0 SURFACE-WATER QUALITY--Continued \\ 7.3 Biology--Continued \\ 7.3.4 Fish
}

\title{
Mountain Streams Support Cold-Water Game Fish
}

\author{
Cold-water game fish are found in mountain streams, but generally not in plains \\ streams; warm-water game fish are found in a few plains streams, but not in \\ mountain streams.
}

Streams in the Bighorn Mountains support coldwater game fish such as rainbow trout, brown trout, brook trout, whitefish, and grayling. The mountain streams have the best ratings as fishery resources, based on the stream-classification system shown in figure 7.3.4-1. The classification system was designed by the U.S. Fish and Wildlife Service in cooperation with the Wyoming Game and Fish Commission (U.S. Fish and Wildlife Service, 1978) and with the Montana Department of Fish, Wildlife, and Parks (U.S. Fish and Wildlife Service, 1980). The system includes the following criteria to evaluate permanent streams, their tributaries, and certain intermittent streams as fishery resources: (1) The presence of endangered or threatened species as designated by the States or Federal government, (2) species of high interest to the State, and (3) habitat restoration or mitigation potential. The Middle Fork Powder River, the only stream to receive a Class 1 designation (highest value as a fishery resource), has been inventoried by the National Park Service for possible designation as a National Wild and Scenic River. The Middle Fork of the Powder River also received a Class I designation (highest) from a rating system used by the Wyoming Department of Environmental Quality (1982).

A few perennial streams in Area 50 support warm-water game fish, but most plains streams, especially intermittent and ephemeral plains streams, do not support a fishery resource. Warm-water game fish found in the plains streams include channel catfish, black bullheads, largemouth bass, bluegills, and sunfish. Non-game fish such as white suckers, carp, redhorse, and bait minnows also are found in plains streams. Baxter and Simon (1970) noted the presence of about 20 species of fish in plains streams of this area. Rehwinkel (1978) found that flathead chubs and sturgeon chubs were the most common species in the Powder River, and that warm-water game fish were present in small numbers.

The ephemeral or intermittent character of the streams in areas of active coal mining inhibits the development of a fishery resource, with the exception of the Little Powder River. The Little Powder River is perennial, drains an area of active coal mining (fig. 7.3.4-1), and supports a limited fishery resource. Wesche and Johnson (1980) studied four small streams near the areas of active coal mining and concluded that they could not be considered practicable as sport fisheries, even though warm-water game fish were present, because of the small numbers and sizes of the fish.

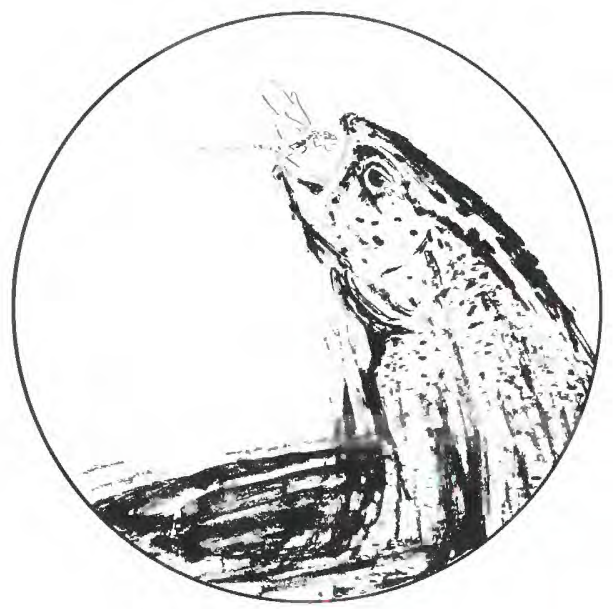




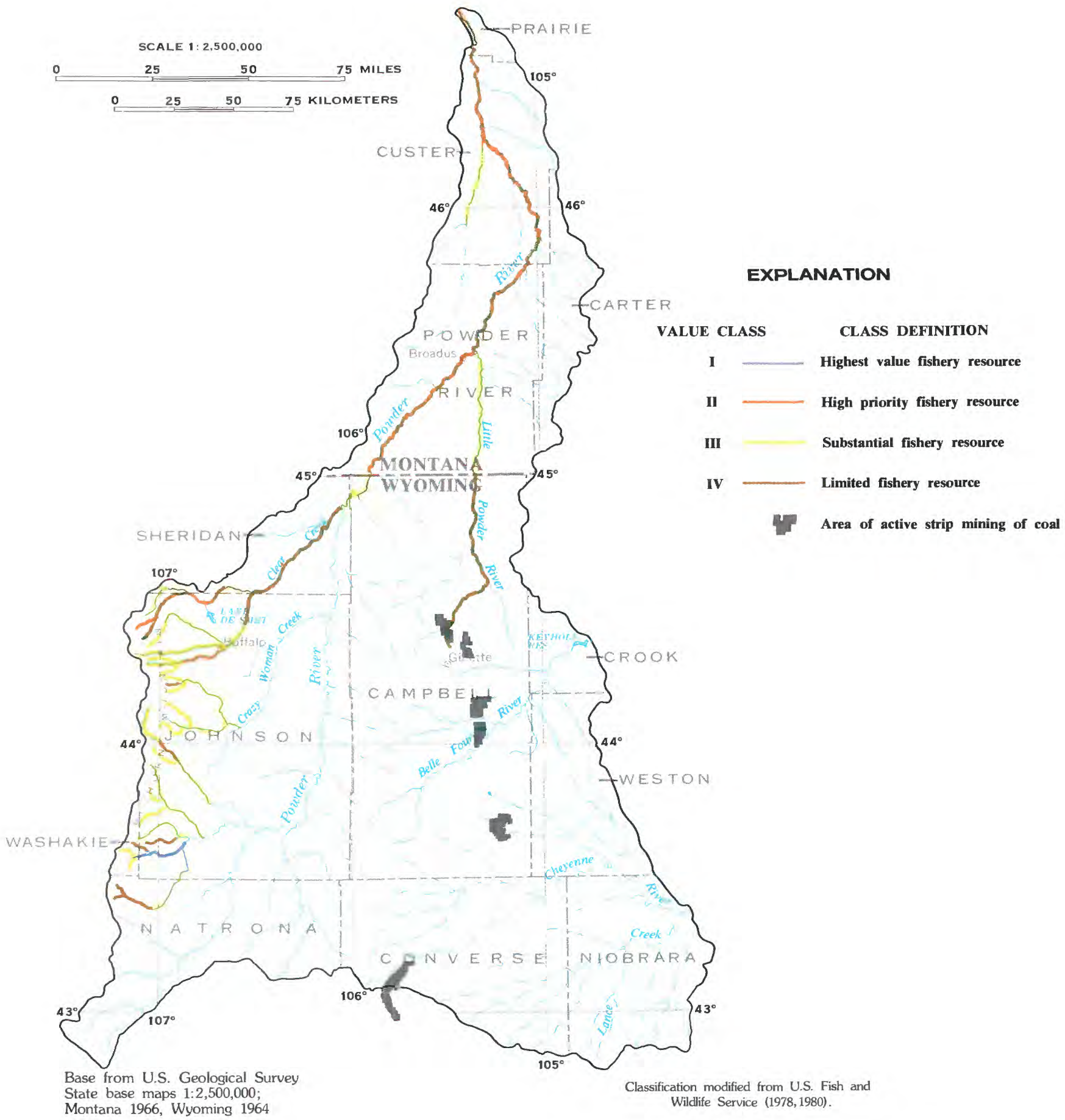

Figure 7.3.4-1 Fishery-resource classification. 


\title{
7.0 SURFACE-WATER QUALITY--Continued 7.4 Temperature
}

\section{Temperature is a Significant Factor of Water Quality}

\author{
Stream temperature affects rates of chemical reactions and biological processes; \\ in Area 50 temperatures can range from 0 degrees Celsius in winter to about \\ 25 degrees Celsius in summer.
}

Observations of water temperature are made at surface-water stations whenever discharge measurements are made. These measurements generally are made monthly; a summary of the temperature data was prepared by Lowham and others (1975). Water temperatures also are obtained daily, monthly, or less frequently when water-quality samples are collected. These data are published in annual reports of the U.S. Geological Survey (1983a, 1983b).

The temperature of water in streams of Area 50 can range from 0 degrees Celsius during winter to 25 degrees Celsius or more during late summer. Observations of water temperature for two example streams are shown in figure 7.4-1. North Piney Creek (station 81) drains a mountainous area of relatively high altitude, whereas Lance Creek (station 139) drains an area of lower altitude in the plains. Water temperatures of North Piney Creek are lower and have less variability than those of Lance Creek because of differences in the climatic and physical conditions of their drainage basins.

Temperature determines the physical form of water (solid, liquid, or vapor) and also affects most physical processes and chemical reactions that take place in water. For example, as water temperature increases, dissolved oxygen decreases because of the decreased saturation capacity of the water and the increased oxygen consumption of aquatic life. In contrast, the solubility of various substances in water increases with temperature. Because of its effect on water quality, temperature affects water use and aquatic life.

Water temperature is important to many water users. It is important to the sportsman, as it is a vital factor affecting fish life. It is important to agricultural users, as temperature of irrigation water can affect crop production. Industrial water users commonly use water for cooling purposes and need to consider stream temperature in plant design and operation.

The temperature of water in streams is significantly affected by the surrounding conditions. Climatic conditions that affect water temperature include solar radiation, wind speed, air temperature, and vapor pressure. Important physical conditions include shading, ground-water inflows, aspect of the stream, and stream width, depth, and velocity. Waste discharges and reservoirs also may have significant effects on the temperature of water in streams. 


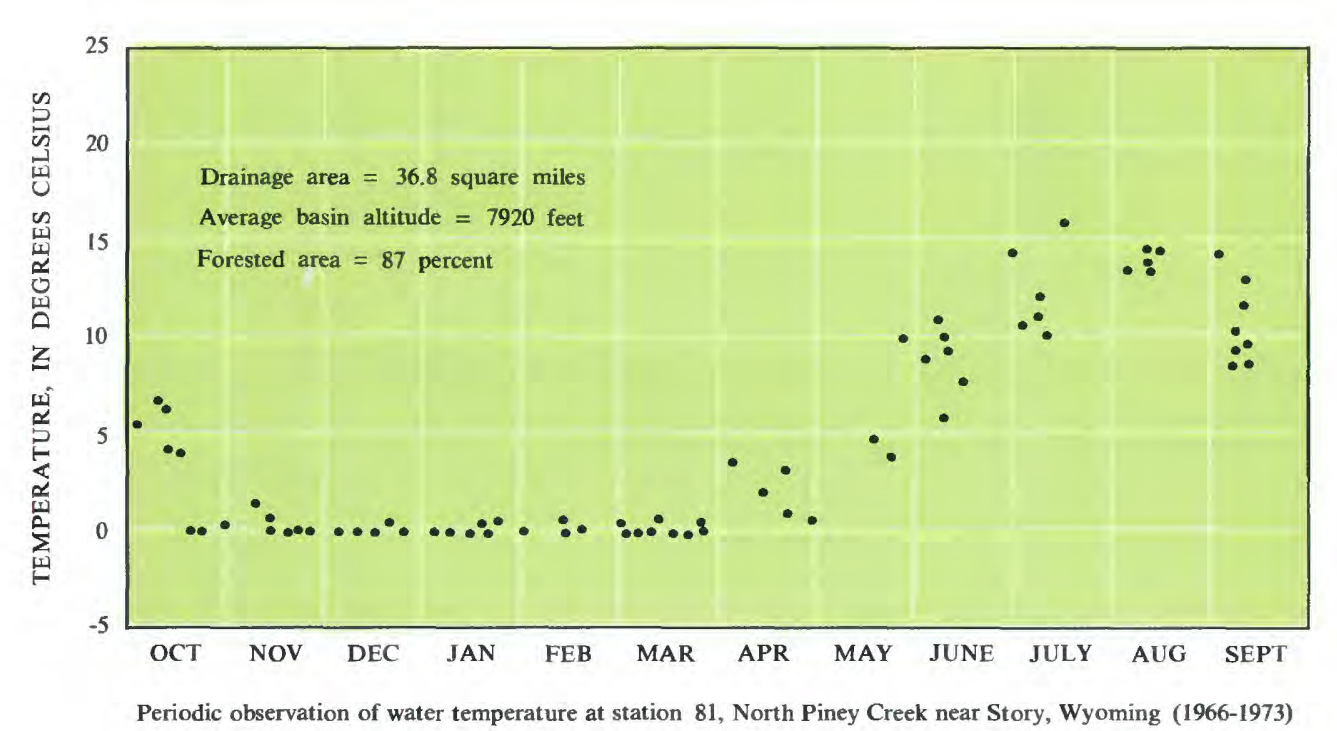

\section{EXPLANATION}

$\nabla_{81} \quad$ STATION AND NUMBER

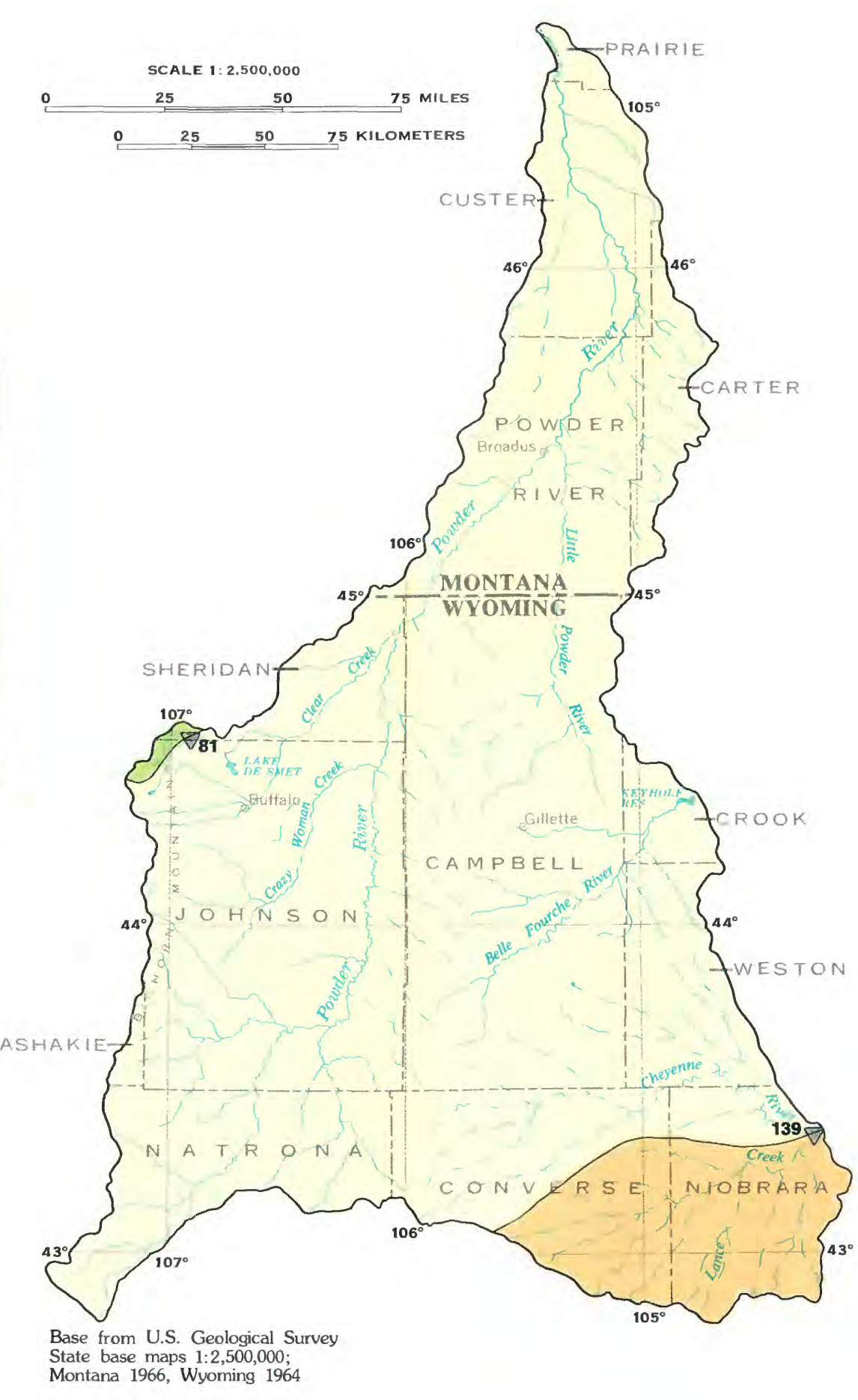

Figure 7.4-1 Observations of water temperature for two example streams.

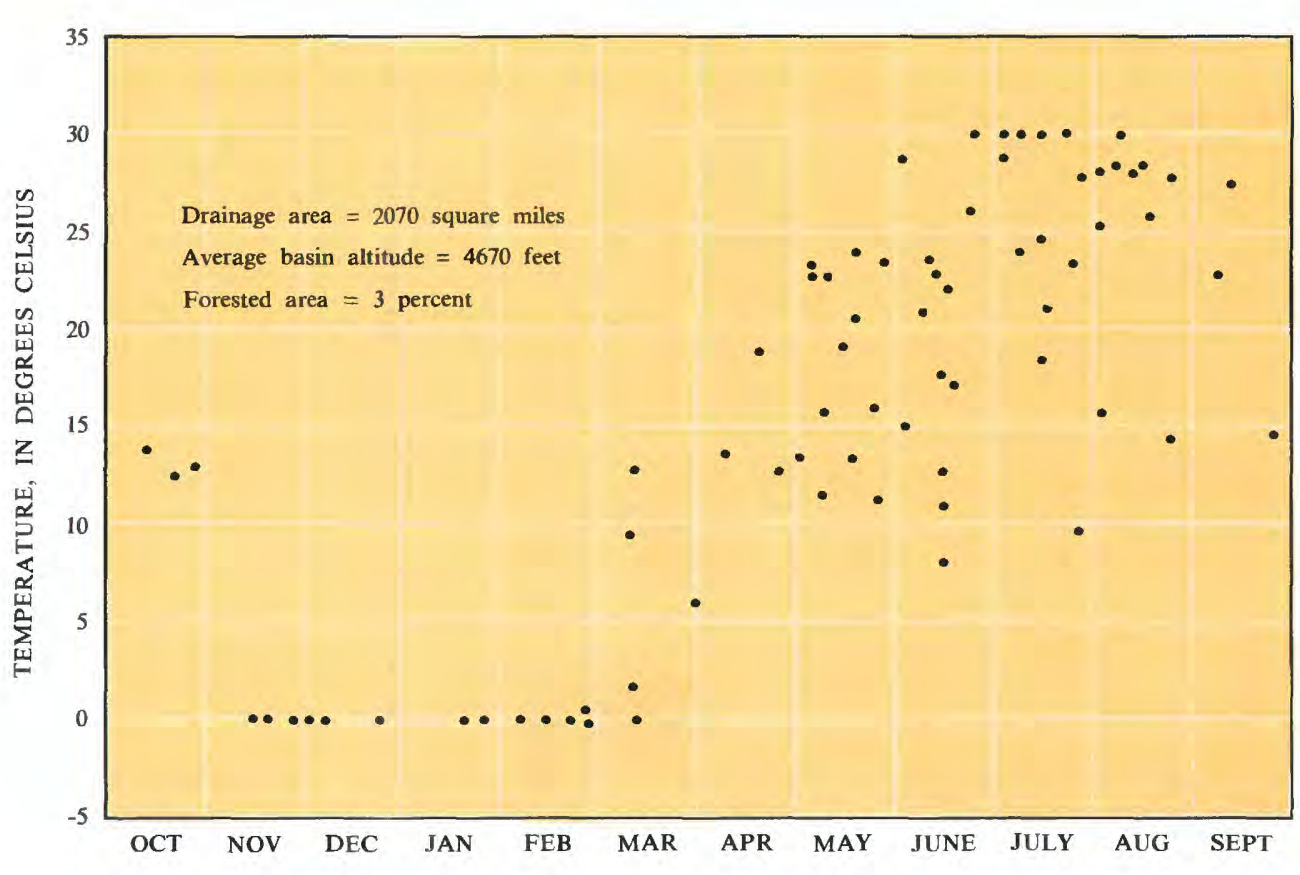

Period observation of water temperature at station 139, Lance Creek near Riverview, Wyoming (1961-1973) 


\subsection{GROUND WATER \\ 8.1 Ground-Water Data}

\section{Data Available for about 3,000 Wells}

\section{Data collected since the mid-1970's emphasize hydrology of small areas and regional aquifer systems.}

The distribution of ground-water-data sites in Area 50 is indicated in figure 8.1-1. The sites shown are those for which quality-of-water, well-yield, water-level, or geologic data are stored in the computer files of the U.S. Geological Survey as of September 1982. These files are continually expanded and revised as the result of studies in the area, but to date (1983) not all the available data are in the files.

Most ground-water data were collected during interpretive studies. The earliest studies in the area by the Geological Survey were by Renick (1924) and Riffenburg (1926). During the mid-1950's, several ground-water studies in Montana and Wyoming were completed by the Geological Survey as part of a special Federal program for the development of the Missouri River Basin. A description of the ground-water resources near Kaycee, Wyo., by Kohout (1957) was the only one of these studies that included part of Area 50.

The Montana Bureau of Mines and Geology conducted some of the earliest studies in the area, including those by Perry, (1931, 1932, and 1935). A cooperative program between the Geological Survey and the Montana Bureau of Mines and Geology began in 1956. Studies that included part of Area 50 were those of the Cedar Creek anticline in eastern Montana (Taylor, 1965) and ground-water resources of the northern Powder River valley (Taylor, 1968).

A cooperative program between the Wyoming State Engineer and the Geological Survey began in 1945. As part of this program, reconnaissance ground-water studies, which include all or part of Area 50, were completed in Crook County (Whitcomb and Morris, 1964); Johnson County (Whitcomb and others, 1966); Natrona County (Crist and Lowry, 1972); and Sheridan County (Lowry and Cummings, 1966). A similar study of Campbell County was started; however, because the State Engineer recognized the need for prompt reconnaissance coverage of a larger area to provide information needed for coal development, the study was expanded to include all northeastern Wyoming. The result was a report by Hodson and others (1973) (fig. 8.1-2).

With the subsequent increase in coal development in the area, a large quantity of ground-water data was collected by industry, universities, and government agencies.
Most of these data were collected to support studies to describe the hydrology and possible environmental impacts in relatively small areas, such as a proposed mine. The government agencies and universities that were most active in acquiring ground-water data are listed in section 10.2.

Much of the ground-water data collected in Campbell County, Wyo., is pooled through the Gillette Area Ground Water Monitoring Organization (GAGMO), an organization consisting principally of mining companies. Water levels in 800 wells completed in the Wyodak-Anderson coal were reported to the organization in 1981, resulting in a compilation of water-level data for most of Campbell County, Wyo., close to the coal outcrop. A copy made of this report is in the Wyoming State Library in Cheyenne.

The Madison Limestone was recognized as a potential source of water for coal development (U.S. Geological Survey, 1975); consequently, during 1975-80, the Geological Survey studied the regional aquifer in parts of Montana, North and South Dakota, Wyoming, and Nebraska (fig. 8.1-2). This regional study was a forerunner of $\mathrm{Re}-$ gional Aquifer System Analysis (RASA) studies by the Geological Survey. The results of the Madison Limestone study are described in a series of reports. Data for the Geological Survey test wells were reported by Blankennagel and others (1977) and by Brown and others (1977). The geology, geochemistry, and hydrology of the aquifer system will be described in Geological Survey Professional Paper 1273. Two chapters have been published: MacCary and others (1983) and Thayer (1983). Five remaining chapters have been released to the open files, pending publication: MacCary (1981), Peterson (1981), Brown and others (1982), Downey (1982a), and Busby and others (1983).

The Northern Great Plains RASA (fig. 8.1-2) was selected as one of the first of the series of RASA studies because of the extensive energy resources in the study area (U.S. Geological Survey, 1979e). This RASA project was completed in 1982. A few of the principal reports about results of the Northern Great Plains study are still in preparation (1983). Selected reports of results to date are: Lobmeyer (1980), Levings (1981a, 1981b), Levings and others (1981), Downey (1982a, 1982b), Larson and Daddow (1984), and Lenfest (1984). 


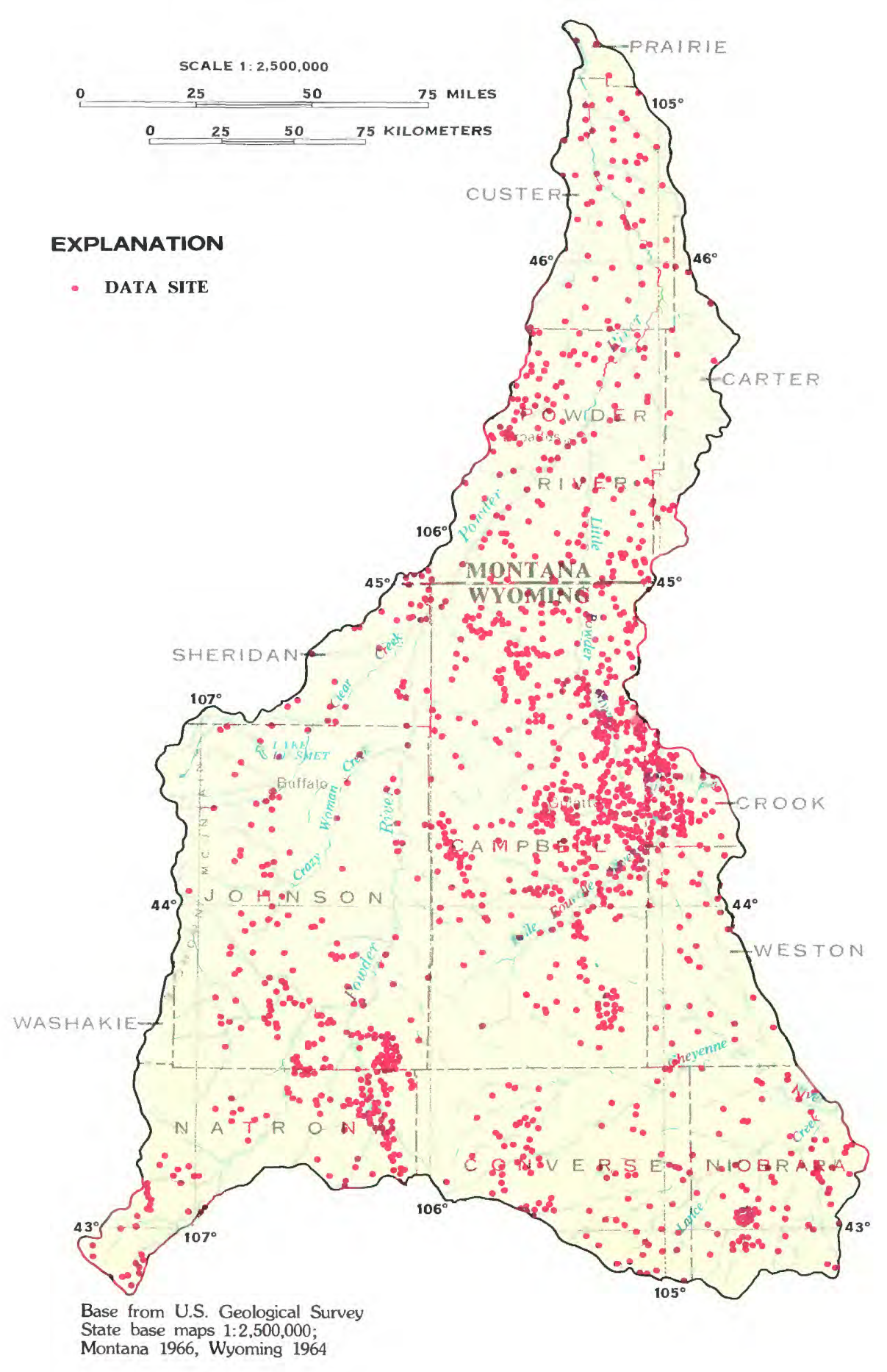

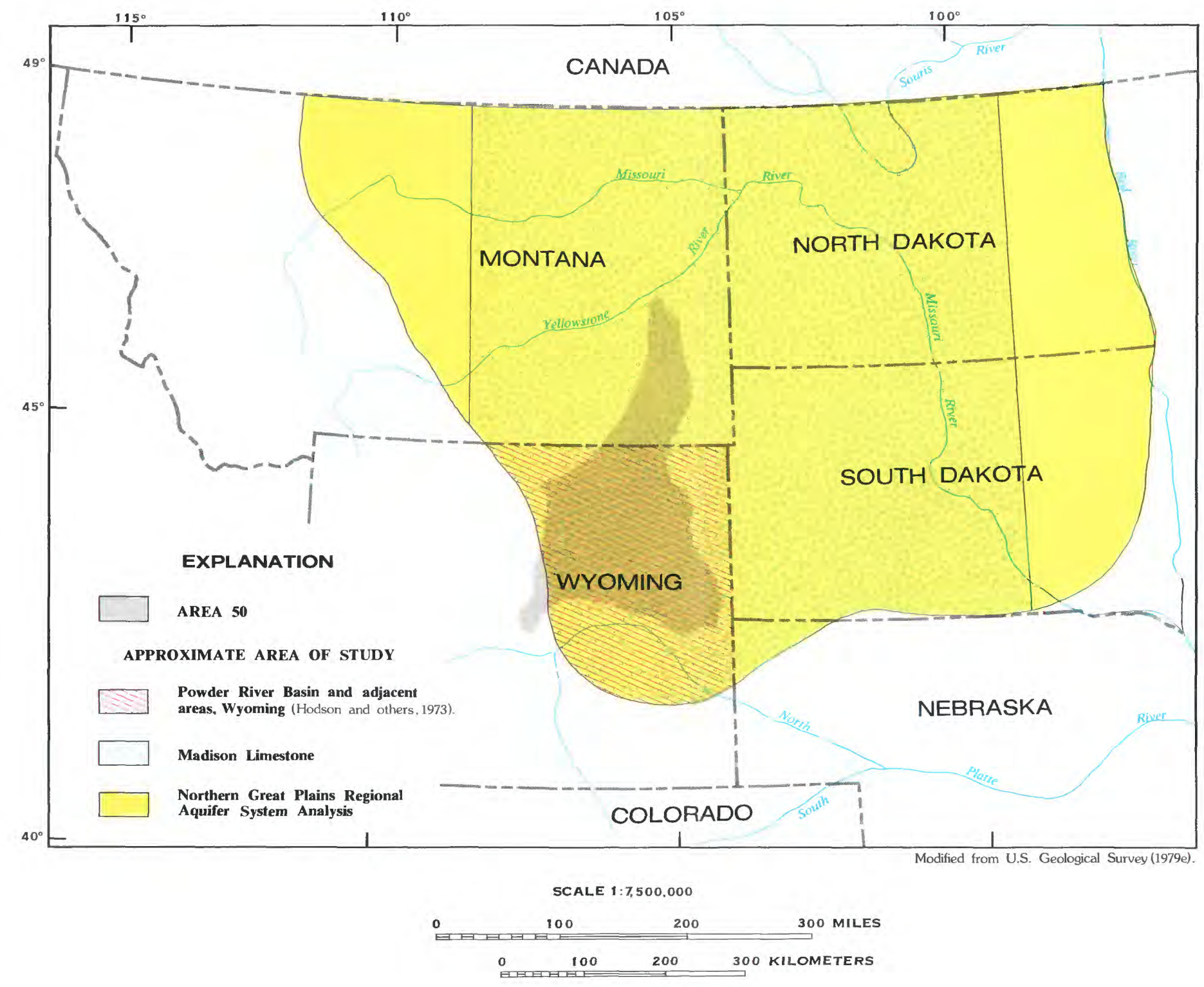

Figure 8.1-2 Location of Area 50 and large-scale ground-water studies that included most of the area. 


\title{
8.0 GROUND WATER--Continued \\ 8.2 Availability
}

\section{Ground Water is Available Throughout Area 50}

\author{
Ground water for stock and domestic use can be developed from wells less than \\ 500 feet deep in most of the area; deeper wells generally are needed to \\ obtain larger yields.
}

The shallowest bedrock in most of the area consists of lower Tertiary and Upper Cretaceous sedimentary rocks. Enough water for stock and domestic use can be obtained in most of the area from wells less than 500 feet deep. Wells commonly are drilled deeper, however, to produce yields such as shown in figure 8.2-1. Flowing wells can be developed principally in the valleys of the major streams such as the Powder, Little Powder and Cheyenne Rivers. Yields greater than 200 gallons per minute can be developed locally from wells less than 1,000 feet deep, and nearly everywhere in Area 50 (except in the mountains) from deeper wells because of the large saturated thickness of the rocks.

Paleozoic sandstone and carbonate rocks, which include the Madison Limestone, are usually considered where large ground-water supplies are sought. Flows of 7,000 and 3,400 gallons per minute were reported for two artesian wells completed in the Madison Limestone at Midwest in northeastern Natrona County, Wyo. (Crist and Lowry, 1972, p. 42). Although yields from the carbonate rocks can be several thousand gallons per minute, they also can be only several tens of gallons per minute. The large yields from carbonate rocks in Area 50 and adjoining areas are possible only as a result of large secondary permeability (which does not occur everywhere) or because of large artesian head above land surface, which occurs at places near the mountains.
The Upper and Lower Cretaceous shale on the east side of Area 50 has the least potential for developing a water supply in the area. The rocks on the western side of the basin have a somewhat greater water-yielding potential than those on the eastern side, because they include the Frontier and Mesaverde Formations, which contain thick sandstone. In most of the area, wells for stockwater are about 1 mile apart. Deep water wells are drilled through shale on the east side of the area into the Lakota Formation. Distribution systems for stock water, commonly tens of miles long, are then constructed from a single well. Because of the great depth to the older rocks in most of the area, water wells have not been drilled into them in the deep parts of the basin. Therefore, the availability of water from these rocks is relatively unknown.

Alluvial deposits are found along even the smallest streams but are too narrow to show in figure 8.2-1. The thickest and coarsest-grained alluvium occurs near the mountains where well yields of as much as 500 gallons per minute are possible. The alluvium distant from the mountains is mostly fine grained and the saturated thickness is generally less than 20 feet, so large water yields are not possible. The largest reported yield from the alluvium of the Powder River is 90 gallons per minute (Whitcomb and others, 1966, p. 47). 


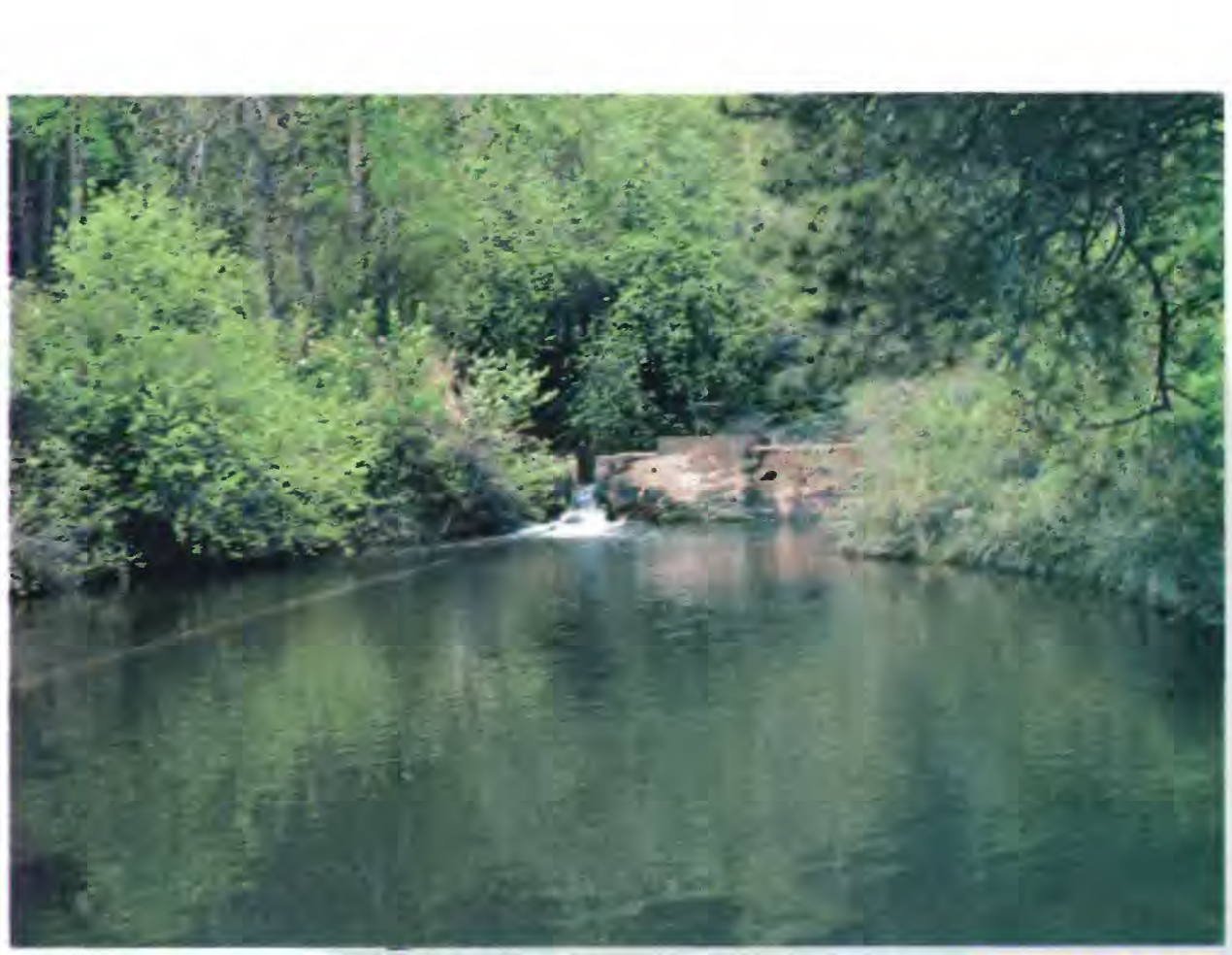

Fish hatchery spring near Story, Wyoming.

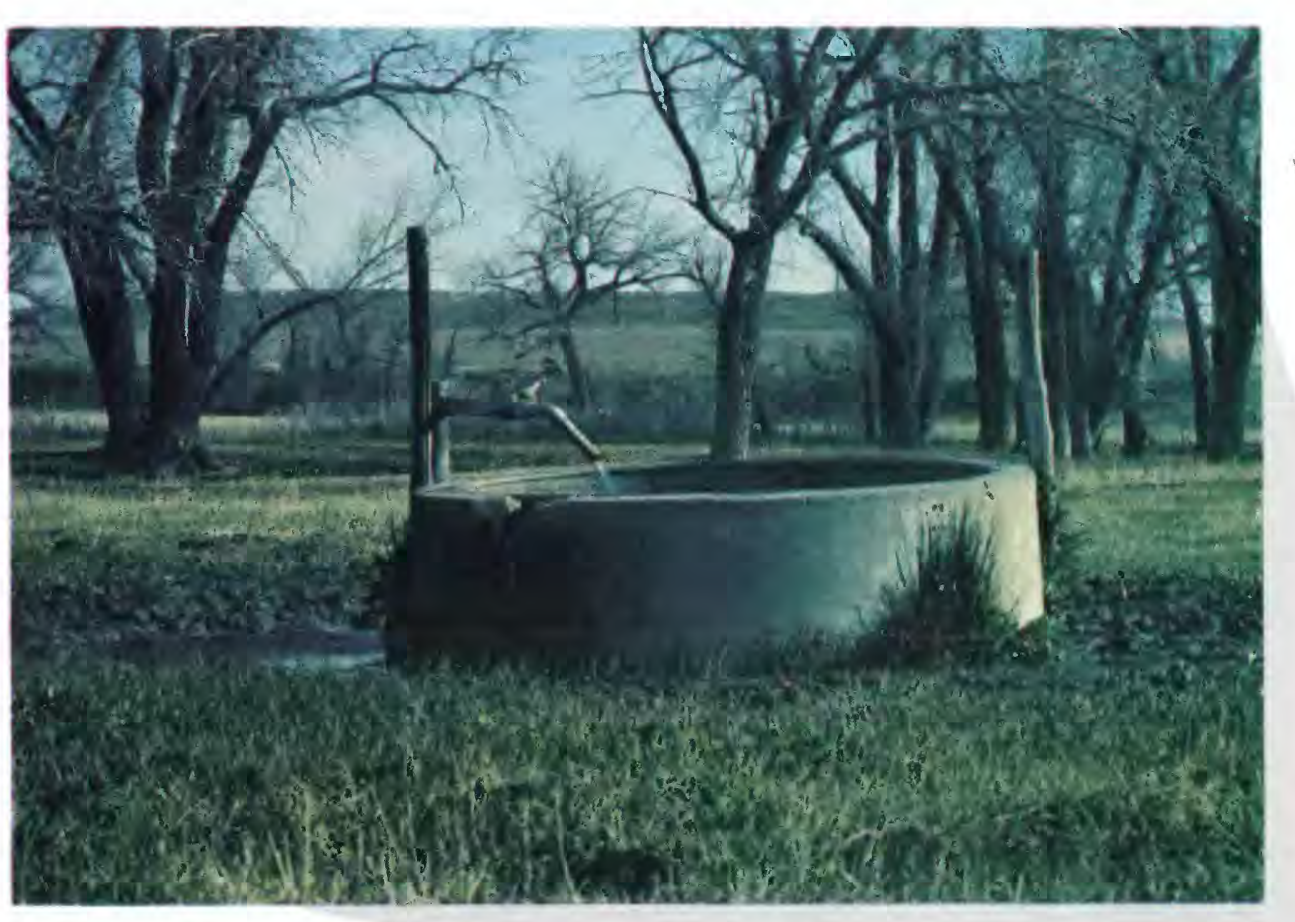

Artesian flow from lower Tertiary sandstone.

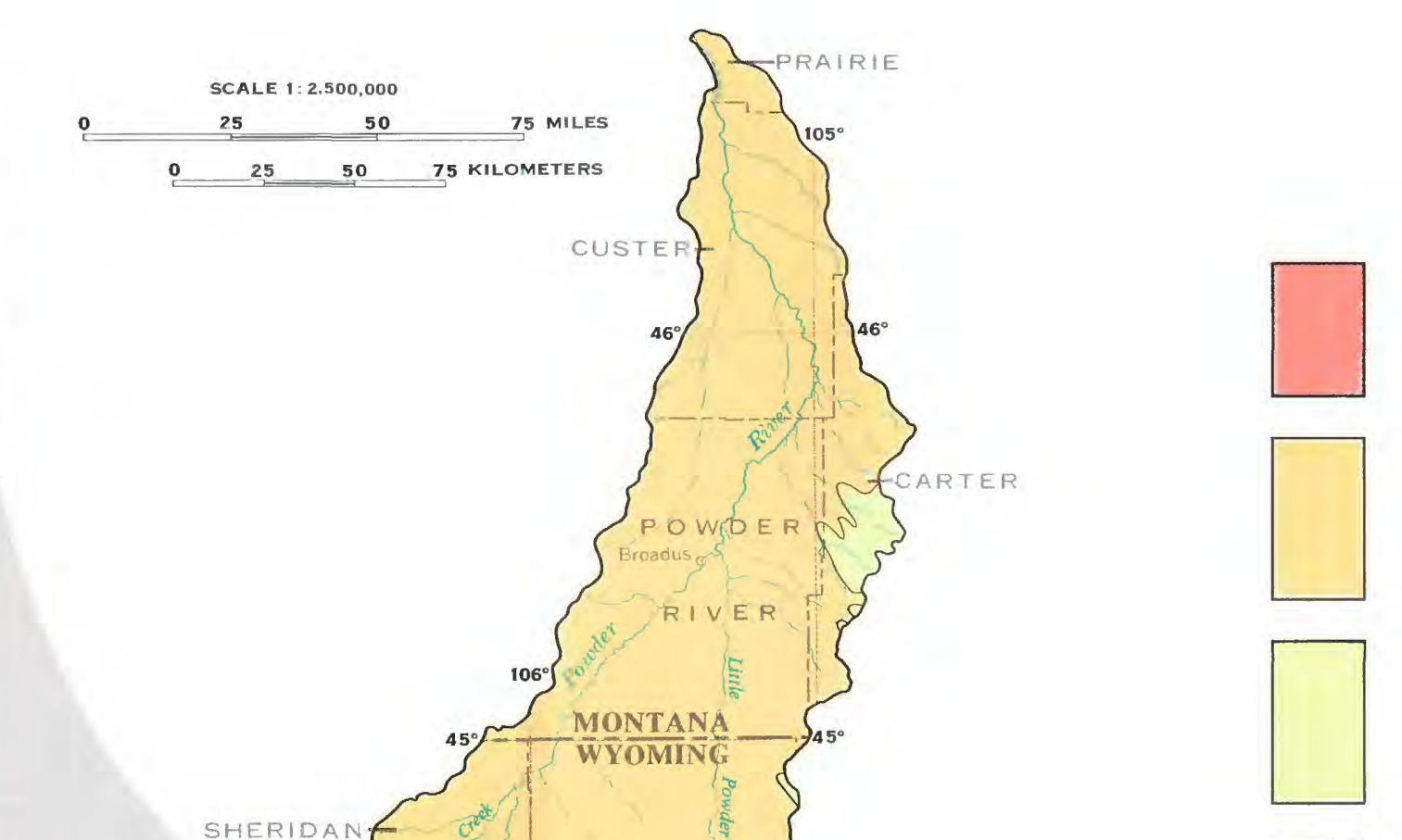

$\square$

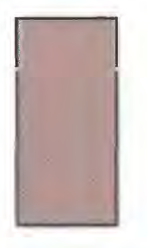

$\square$
EXPLANATION

UPPER TERTIARY CONTINENTAL ROCKS--Generally do develue ent of water well this Sprins for do commonly yield less than 25 gallons per minute are numerous

LOWER TERTIARY AND UPPER CRETACEOUS CONTINENTAL Rocks--Contain many sandstone lenses and coal beds from which yields of 10 to 20 gallons per
minute can be obtained. Yields of 500 gallons per minute have been obtained from wells 5,000 feet deep

UPPER AND LOWER CRETACEOUS SHALE--Little potential for development of water supplies. The most side of the area. Wells, which generally yield less than 50 gallons per minute, have been

LOWER CRETACEOUS AND JURASSIC ROCKS--A source of supplies of less than 50 gallons per minute.

than 25 gallons per minute, are abundent

JURASSIC, TRIASSIC, AND PERMIAN RED-BED SEQUENCE-Contains some gypsum, which may develop solution
cavities, and sandstone that yield Fewer than 10 wells are known to be completed in these rocks in Area 50

PALEOZOIC SANDSTONE AND CARBONATE ROCKS--Have the most potential for developing large groundwater supplies. Fractures and solution opening yield as much as several thousand gallons per only several tens of gallons per minute are common

PRECAMBRIAN IGNEOUS AND METAMORPHIC ROCKS--Will yield as much as 25 gallons per minute to springs and wells penetrating fractures or
openings caused by weathering in the outcrop area
Base from U.S. Geological Survey
State base maps 1:2,500,000.

Base from U.S. Geological Sur
State base maps 1 1.2,500,000;
Montana 1966, Wyoming 1964
Modified from Keefer (1974.) 


\title{
8.0 GROUND WATER--Continued
}

\author{
8.3 Recharge and Movement
}

\section{Three Aquifers Show Distinctive Patterns of Ground-Water Movement}

\author{
Recharge to the principal aquifers occurs mainly in the outcrop areas near the southern, western, \\ and eastern boundaries of Area 50. Small quantities of water probably move out of the area \\ in the Madison and Lower Cretaceous aquifers; movement in the coal aquifers is complex.
}

Water movement in an aquifer generally is inferred from potentiometric-surface maps such as shown in figure 8.3-1. Movement from recharge area to discharge area generally is at right angles to the potentiometric contours. However, in very permeable zones such as the fractures and solution openings that occur in the Madison aquifer, movement of water may follow the fractures and in some instances may be nearly parallel to the contours.

The Madison aquifer includes the Mission Canyon and Lodgepole Limestones of the Madison Group in Montana, and the Madison and Pahasapa Limestones in Wyoming. The map of the potentiometric surface of water in the Madison aquifer (fig. 8.3-1) shows that recharge to the aquifer occurs in the uplifted areas of the Black Hills and the Bighorn and Laramie Mountains in or adjacent to the study area.

Water movement in the Madison aquifer is locally controlled by structural features associated with zones of high permeability along the Bighorn Mountains and the Black Hills. West of the Black Hills, fracture zones that are very transmissive seem to divert the water to the north and south (Fitzwater, 1981) and therefore restrict the amount of flow into the center of the basin. Also, east of the Bighorn Mountains, in Johnson County, Wyo., faulting has broken the hydrologic continuity between the outcrop area and the aquifer in the basin, restricting flow into the basin (Blackstone, 1981). The potentiometric surface of the Madison aquifer seems to be flat, based on a limited quantity of data for the center of the basin. According to Swenson and others (1976), the flatness could indicate either a small quantity of flow or a larger transmissivity. A small quantity of flow could be due to a combination of (1) less movement because of the large permeability zones diverting the flow northward, and (2) discharge into the overlying Lower Cretaceous aquifer. Larger transmissivity would result from the high water temperatures and northward thickening of the formation. The principal discharge area for the Madison aquifer is in eastern North and South Dakota and the Province of Manitoba, Canada (Downey, 1982a). Leakage into the overlying Lower Cretaceous aquifer also accounts for some discharge from the Madison aquifer.

The Lower Cretaceous aquifer includes stratigraphic units from the Muddy and Newcastle Sandstones down to the Cloverly Formation and Lakota Sandstone (see fig. 3.6.1-3). Recharge to this aquifer is principally due to leakage from the underlying Madison aquifer, as indicated in a study by Dwight T. Hoxie and Kent C. Glover (U.S. Geological Survey, written commun., 1983) and shown in figure 8.3-2. The Lower Cretaceous aquifer is also recharged in the uplifted areas of the Black Hills and the Bighorn and Laramie Mountains in or adjacent to the study area. The closed circles in the potentiometric surface at the Wyoming-Montana State line are a low-pressure anomaly. This anomaly is the principal control of water movement in the aquifer. Hoxie and Glover (written commun., 1983) report that 76 percent of the water movement in the Lower Cretaceous aquifer is toward the lowpressure anomaly. In the trough in southeastern Johnson County, Wyo., ground water moves to replace oil pumped from the Lower Cretaceous formations at the Salt Creek oil field in northeastern Natrona County, Wyo.

Water movement in the shallow aquifers in the Powder River Basin, Wyoming (most of Area 50) is best described by movement in the coals, as these are the most extensive aquifers. Maps of the potentiometric surfaces for the School coal bed in Converse County, Wyo., and the Wyodak-Anderson coal bed elsewhere in the area are shown in figure 8.3-3. Most of the water-level data along the coal outcrops were obtained from the coal companies operating there. Recharge to the School and WyodakAnderson coal beds occurs along the outcrops, as shown on the map.

The potentiometric-surface map for the School coal bed indicates ground-water flow to the north and east. The potentiometric-surface map for the Wyodak-Anderson coal bed in figure 8.3-3 indicates movement to the north along the eastern outcrop with some discharge in the Gillette area. However, near the Wyoming-Montana border, movement is to the west in the aquifer. Because water-level data are not available to determine how the northward flow and westward flow are related, this may not be a true representation of the potentiometric surface describing regional flow.

Potentiometric maps published between 1980 and 1983 for all or a part of Area 50, in addition to those mentioned previously, include maps of the Lower Cretaceous aquifer in Montana, North Dakota, South Dakota, and Wyoming (Lobmeyer, 1980), the Judith River aquifer in Montana (Levings, 1982a), the Lakota aquifer in Montana (Levings, 1982b), the Fox Hills-lower Hell Creek aquifer in Montana (Levings, 1982c), and the Eagle Sandstone aquifer in Montana (Levings, 1982d). 


$$
\Delta 4 \mathrm{~B}
$$




\author{
8.0 GROUND WATER--Continued \\ 8.4 Chemical Quality \\ 8.4.1 Dissolved Solids
}

\title{
High Dissolved-Solids Concentrations in Most Ground-Water Supplies
}

\author{
Eighty-four percent of the wells and springs have water with dissolved-solids \\ concentrations greater than the recommended national drinking-water standard \\ of 500 milligrams per liter. Nearly all sources sampled, however, are \\ suitable for watering livestock.
}

The histogram for dissolved-solids concentrations from the area's wells and springs (fig. 8.4.1-1) shows that concentrations are less than the $500-\mathrm{mg} / \mathrm{L}$ (milligrams per liter) maximum recommended by the National Secondary Drinking Water Regulations (U.S. Environmental Protection Agency, 1979) in only 110 of 693 samples (about 16 percent). The secondary regulations are not mandatory, however, and the recommended $500-\mathrm{mg} / \mathrm{L}$ maximum for drinking water commonly is exceeded in the arid West because a practical alternative source is not available. Many rural dwellers are pleased to have wells that yield water with dissolved-solids concentrations of $1,000 \mathrm{mg} / \mathrm{L}$ or less. About 45 percent of the samples are in this category.

Most of the wells and springs in the area are used for watering livestock. Salinity (dissolved-solids) standards for livestock, published by the National Academy of Sciences and National Academy of Engineering (1973), may be summarized as follows:

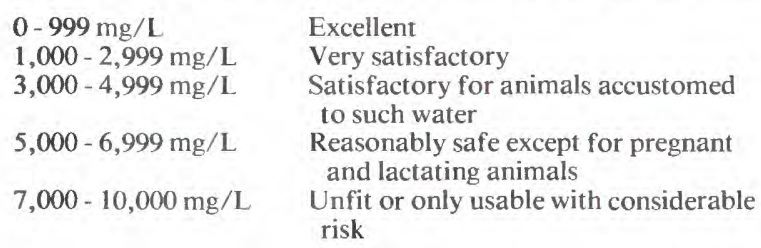

Based on these standards, 98 percent of the samples were satisfactory or better for livestock watering.

To some extent the well samples for salinity have a built-in bias because the wells have not been drilled at random. Wells are not likely to be drilled in areas known to have dissolved-solids concentrations that are hazardous to livestock. In addition, if a well were drilled and the water was too saline, the rancher would abandon the well. Furthermore, the analyses of samples in Geological Survey files generally do not include oil-field data that represent deeper aquifers that yield more saline water. For these reasons the samples are biased toward less mineralized ground water and are not truly representative of the area.

A statistical summary of dissolved-solids concentrations for aquifers with 10 or more samples is shown in table 8.4.1-1. Generally, the water in each aquifer has a considerable range in dissolved-solids concentrations. Samples from the Wasatch Formation contained from 227 to $8,200 \mathrm{mg} / \mathrm{L}$ of dissolved solids, whereas those from the Fort Union Formation contained from 209 to $5,620 \mathrm{mg} / \mathrm{L}$. Together, these two formations account for 65 percent of all samples.

Although other factors are involved, the length of flow time or the length of the flow path from recharge to discharge or withdrawal is probably the dominant factor affecting the dissolved-solids concentration in most aquifers. Wells close to recharge areas generally have the lowest dissolved-solids concentrations, whereas wells remote from the recharge areas have high dissolved-solids concentrations. The samples from the Tensleep Sandstone have the lowest median concentration $(254 \mathrm{mg} / \mathrm{L})$ of all the aquifers sampled, because most samples were collected from wells and springs near the Bighorn Mountains, where the formation crops out and where recharge occurs. However, a sample from the Tensleep Sandstone obtained near the middle of the basin, far from the recharge site, had a dissolved-solids concentration of $6,820 \mathrm{mg} / \mathrm{L}$. 


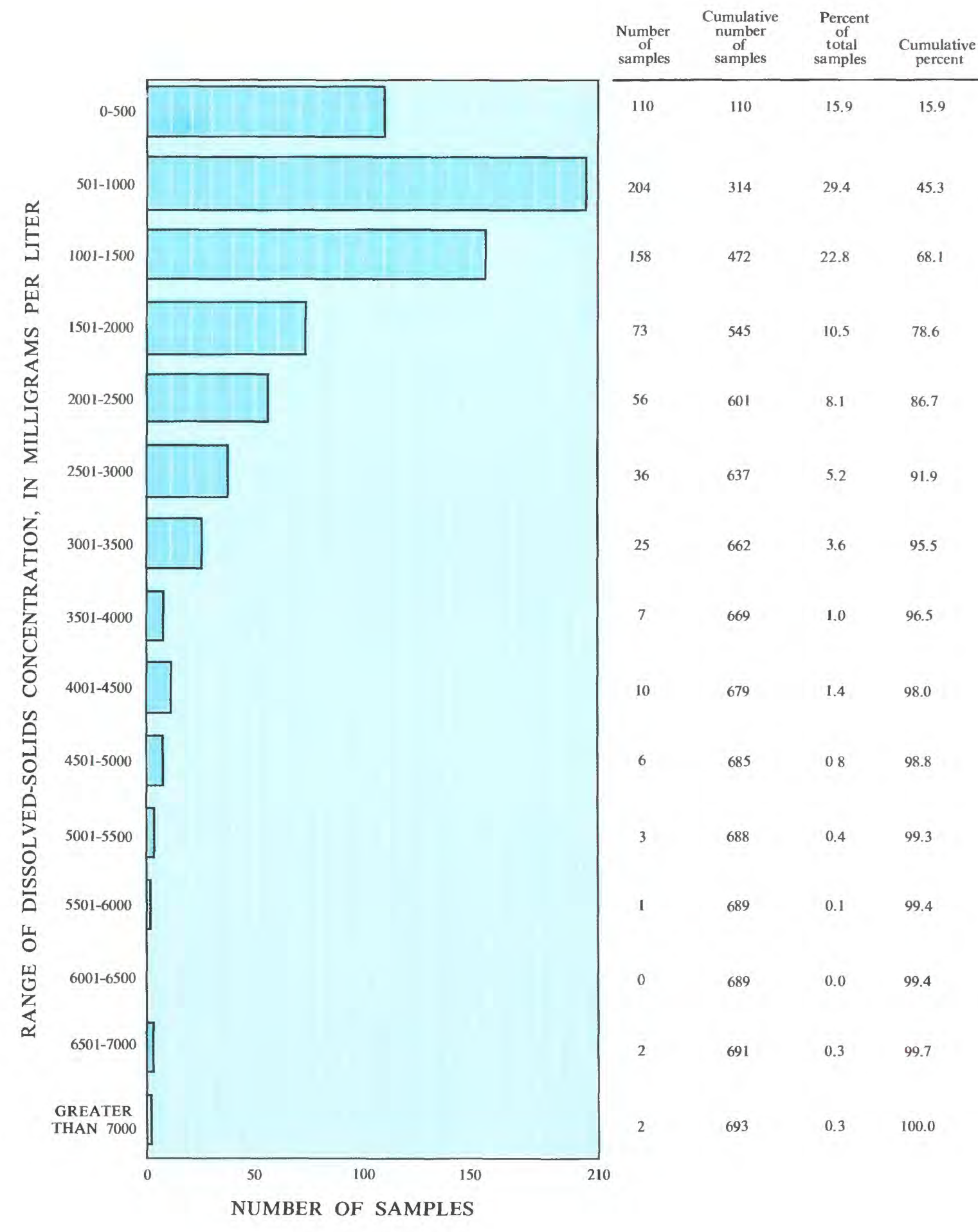
Table 8.4.1-1 Median, average, minimum, and maximum dissolved-

\begin{tabular}{|c|c|c|c|c|c|}
\hline \multirow[b]{2}{*}{ Aquifer } & \multicolumn{4}{|c|}{$\begin{array}{c}\text { Dissolved-solids concentration } \\
\text { (milligrams per liter) }\end{array}$} & \multirow{2}{*}{$\begin{array}{l}\text { Number } \\
\text { of samples }\end{array}$} \\
\hline & Median & Average & Minimum & Maximum & \\
\hline Alluvium & 1,700 & 2,128 & 106 & 6,610 & 38 \\
\hline Wasatch Formation & 1,010 & 1,298 & 227 & 8,200 & 191 \\
\hline Fort Union Formation & 1,260 & 1,464 & 209 & 5,620 & 257 \\
\hline $\begin{array}{l}\text { Fox Hills-Hell Creek } \\
\text { Formations }\end{array}$ & 691 & 790 & 340 & 2,850 & 24 \\
\hline Fox Hills Sandstone & 943 & 1,494 & 451 & 5,450 & 26 \\
\hline Hell Creek Formation & 800 & 978 & 408 & 2,390 & 23 \\
\hline Lance Formation & 977 & 1,218 & 251 & 2,850 & 31 \\
\hline Tensleep Sandstone & 254 & 874 & 230 & 6,820 & 15 \\
\hline Madison Group & 987 & 1,503 & 65 & 3,240 & 25 \\
\hline
\end{tabular}

Figure 8.4.1-1 Histogram of dissolved-solids concentrations. 


\title{
8.0 GROUND WATER--Continued \\ 8.4 Chemical Quality--Continued \\ 8.4.2 Trace Metals
}

\section{High Manganese and Iron Concentrations--A Common Problem}

\author{
Manganese concentrations exceed the recommended drinking-water standard in \\ about 43 percent of the wells sampled and iron concentrations exceed the \\ standard in about 35 percent of the wells. High selenium concentrations \\ in some wells may indicate a problem.
}

Both manganese and iron concentrations in the area's ground-water samples frequently exceed the maximum allowable concentration when used for domestic supplies (table 8.4.2-1). The National Secondary Drinking Water Regulations recommend a maximum concentration of $50 \mu \mathrm{g} / \mathrm{L}$ (micrograms per liter) for manganese and $300 \mu \mathrm{g} / \mathrm{L}$ for iron (U.S. Environmental Protection Agency, 1979). Domestic supplies and stock watering are both important uses for ground water in the area. For domestic use high manganese and high iron concentrations cause taste and staining (laundry and plumbing fixtures) problems. For stock watering, however, high manganese and iron concentrations are not problems.

Selenium concentrations exceeded the national primary drinking-water standard in 4 out of 159 ground-water samples (table 8.4.2-1). The National Interim Primary Drinking Water Regulations list a maximum allowable selenium concentration of 10 $\mu \mathrm{g} / \mathrm{L}$ (U.S. Environmental Protection Agency, 1977). (The primary drinking-water regulations are mandatory and are designed to safeguard the consumer's health, in contrast to the secondary standards, which are not mandatory but are only recommended for esthetic or economic reasons.) High selenium concentrations in some of the area's ground-water samples are not unexpected, because local selenium problems are known to exist in the area.

Plant uptake and concentration of selenium from seleniferous soils in parts of Wyoming have caused alkali disease (selenium poisoning) in foraging livestock. However, selenium poisoning of livestock from drinking water has not been documented (Beath, 1943). Nonetheless, a maximum concentration of $50 \mu \mathrm{g} / \mathrm{L}$ selenium in livestock water has been recommended (National Academy of Sciences and National Academy of Engineering, 1973). The maximum selenium concentration determined from the area's ground-water samples was $31 \mu \mathrm{g} / \mathrm{L}$. Besides soils, irrigation water is also a recognized source of selenium. In order to prevent a hazardous buildup of selenium in forage crops a maximum selenium concentration of $20 \mu \mathrm{g} / \mathrm{L}$ is recommended (National Academy of Sciences and National Academy of Engineering, 1973). Despite the toxicity of high concentrations, selenium is now recognized to be an essential trace element in animal diet.

In 6 out of 165 samples lead concentration exceeded the primary drinking-water standard. The National Primary Interim Drinking Water Regulations list a maximum allowable lead concentration of $50 \mu \mathrm{g} / \mathrm{L}$ (U.S. Environmental Protection Agency, 1977). Most high lead concentrations are not due to natural conditions, but are the result of corrosion (U.S. Environmental Protection Agency, 1976). Contamination from paint on acid ampoules used in preserving the water samples may also be responsible for some high lead concentrations. 
Table 8.4.2-1 Trace-metal concentrations in ground water in Area 50.

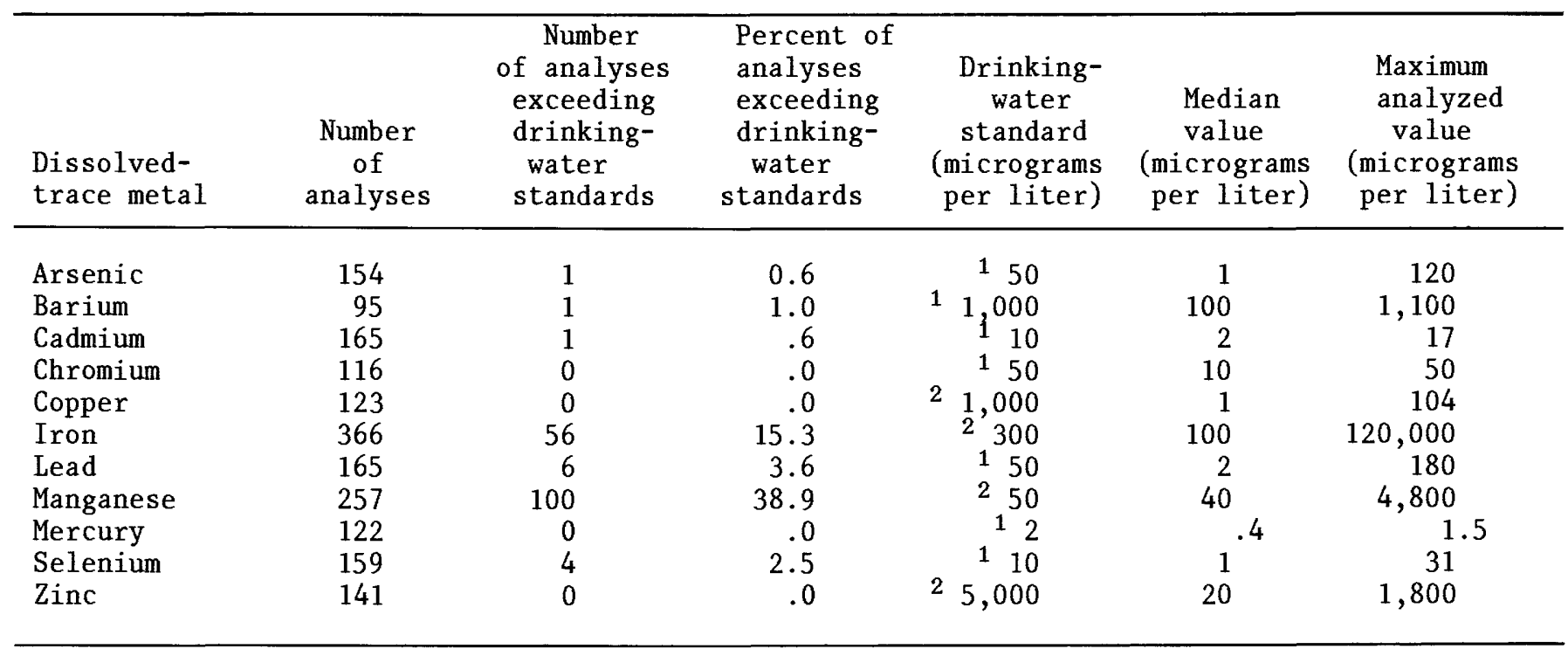

1 National interim primary drinking-water standards (U.S. Environmental Protection Agency, 1977)

2 National secondary drinking-water regulations (U.S. Environmental Protection Agency, 1979) 


\title{
8.0 GROUND WATER--Continued \\ 8.4 Chemical Quality--Continued \\ 8.4.3 Ground-Water-Quality Controls
}

\section{Lithology, Chemical Reactions, and Other Factors Control Water Quality}

\author{
Dissolved-solids concentrations in water usually increase with depth; in the \\ coal-bearing rocks dissolved-solids concentrations in water decrease with depth.
}

The chemical quality of ground water is controlled by the solubility of the rocks and minerals that comprise the aquifer, the reactions that occur as the water moves through the aquifer, the $\mathrm{pH}$ and temperature of the water, pressure, and, to some extent, the length of time that the water is in contact with the rocks. The differences in chemical quality that result from water moving through different rock types are illustrated by three curves in figure 8.4.3-1. Specific conductance, a measure of the electrical conductance of water, is closely related to the concentration of dissolved solids in the water. The data used in the figure are from all of Natrona County, Wyo. (Crist and Lowry, 1972), not just the part in Area 50. The only difference between the rock sequences used in figure 8.4.3-1 and those used elsewhere in this report is that the Fox Hills Sandstone is included with the Upper and Lower Cretaceous shale in figure 8.4.3-1. The differences between the three curves are attributed principally to differences in the lithology of the units and to the chemical reactions that occur as the water moves through the rocks. The increase in specific conductance of water from wells and springs in the upper Tertiary sequence illustrates the increase in dissolved solids that normally occurs as water moves through an aquifer. The sample with the smallest specific conductance was collected from a spring near the recharge area; samples from wells farther from the recharge area have larger specific conductances; and the samples that have specific conductances larger than 900 microsiemens were collected in an area where ground water is discharged into playa lakes and the dissolved solids are concentrated. Travelers on the Oregon Trail gathered salts deposited in those lakes for baking soda. Natrona County was named for the salt that is deposited in playas: Natron is sodium carbonate $\left(\mathrm{Na}_{2} \mathrm{CO}_{3} \bullet 10 \mathrm{H}_{2} \mathrm{O}\right)$; trona is a combination of sodium carbonate and bicarbonate, $\left(\mathrm{Na}_{2} \mathrm{CO}_{3} \mathrm{Na} \mathrm{HCO}_{3} \bullet 2 \mathrm{H}_{2} \mathrm{O}\right)$.

In contrast to the increase in dissolved-solids concentration that normally occurs as water moves through an aquifer, there is a decrease in dissolved-solids concentration in water moving through the lower Tertiary and
Upper Cretaceous continental rocks (fig. 8.4.3-2). The chemical quality of water in these deposits has been described by Riffenburg (1926), Thorstenson and others (1979), and Lee (1979). The dominant reactions that control the quality of water in these rocks are cationexchange softening and sulfate reduction. Cation exchange is a reaction in which the calcium and magnesium in the water are exchanged for sodium from solids such as clay, resulting in soft water. Sulfate reduction is a reaction whereby sulfate in the water is chemically reduced in the presence of organic material to form bicarbonate and sulfide. Water from shallow wells has large concentrations of calcium and magnesium, sulfate, and total solids; water from deep wells has small concentrations of calcium and magnesium, sulfate, and solids. Trace-metal concentrations in the water are small because trace metals in solution react with the sulfide resulting from sulfate reduction to form a precipitate that is relatively insoluble at the $\mathrm{pH}$ of the water.

The chemical quality of water in the alluvium varies with the composition of the alluvium and with the proximity to the mountains. The alluvium derived from the more-resistant rocks in the mountains generally contains water with smaller dissolved-solids concentrations than occur in alluvium derived from rocks in the plains. Water in alluvium of streams that originate in the mountains is of better quality in the mountains than it is in the plains. This is in part because of increased transpiration on the broader flood plains, which results in concentration of dissolved solids in the water, and in part because of the downstream increase in fine-grained sediment derived from rocks in the plains.

The quality of water in each of the geologic sequences is summarized in figure 8.4.3-3. However, the reader is cautioned that this summary is a gross generalization and that the quality of water from aquifers in deep parts of the area is not well known. 


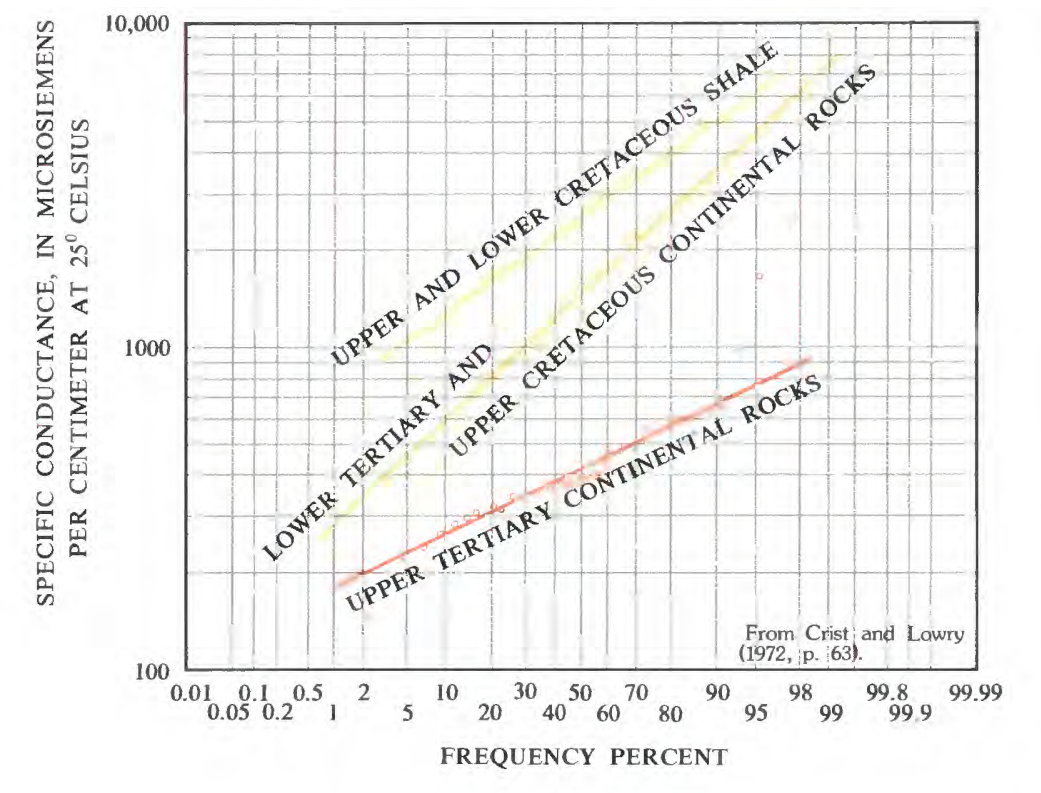

Figure 8.4.3-1 Differences in specific conductance within and between the indicated rock sequences.

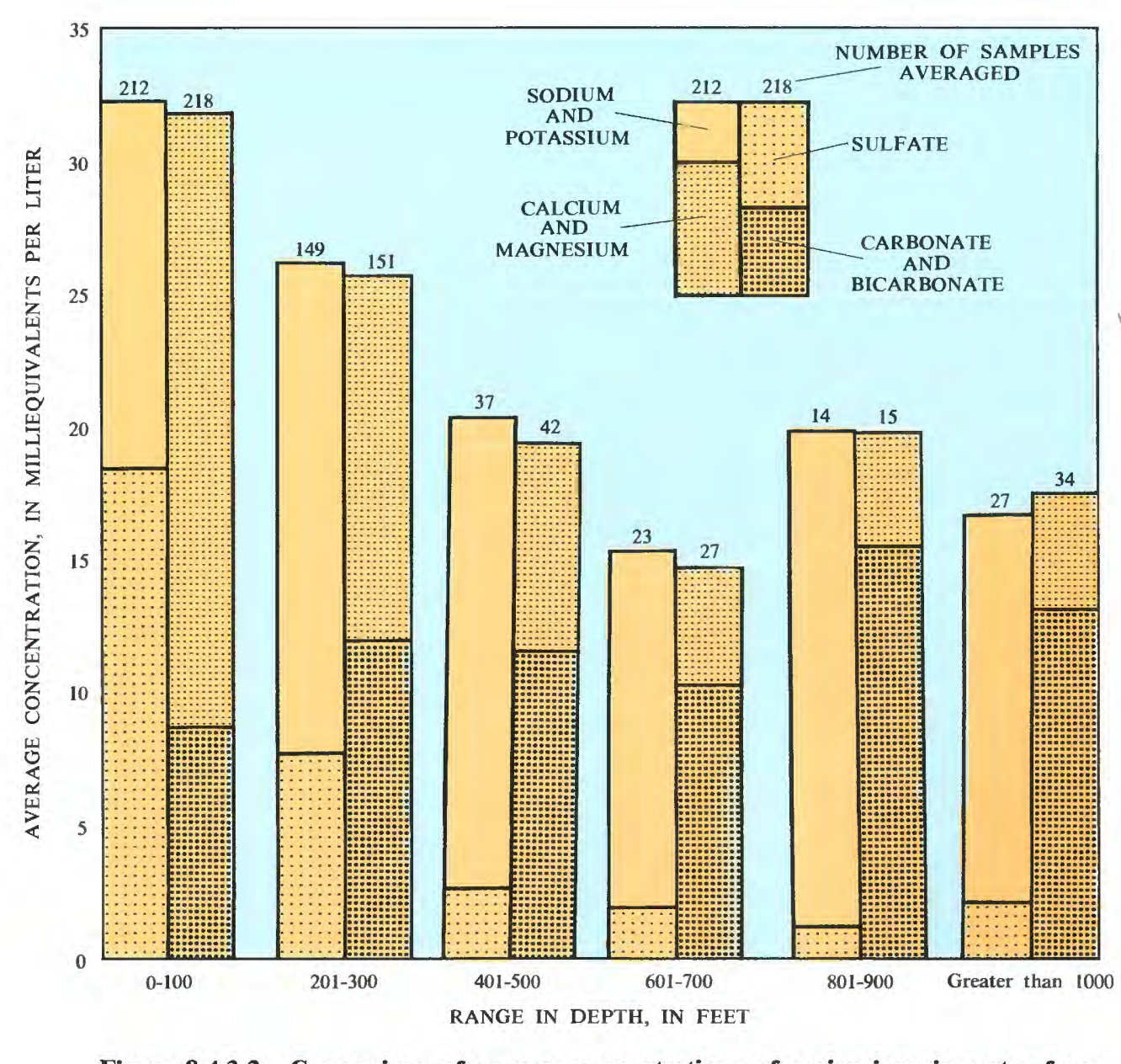

Figure 8.4.3-2 Comparison of average concentrations of major ions in water from springs and wells in the Lower Tertiary and Upper Cretaceous rocks.

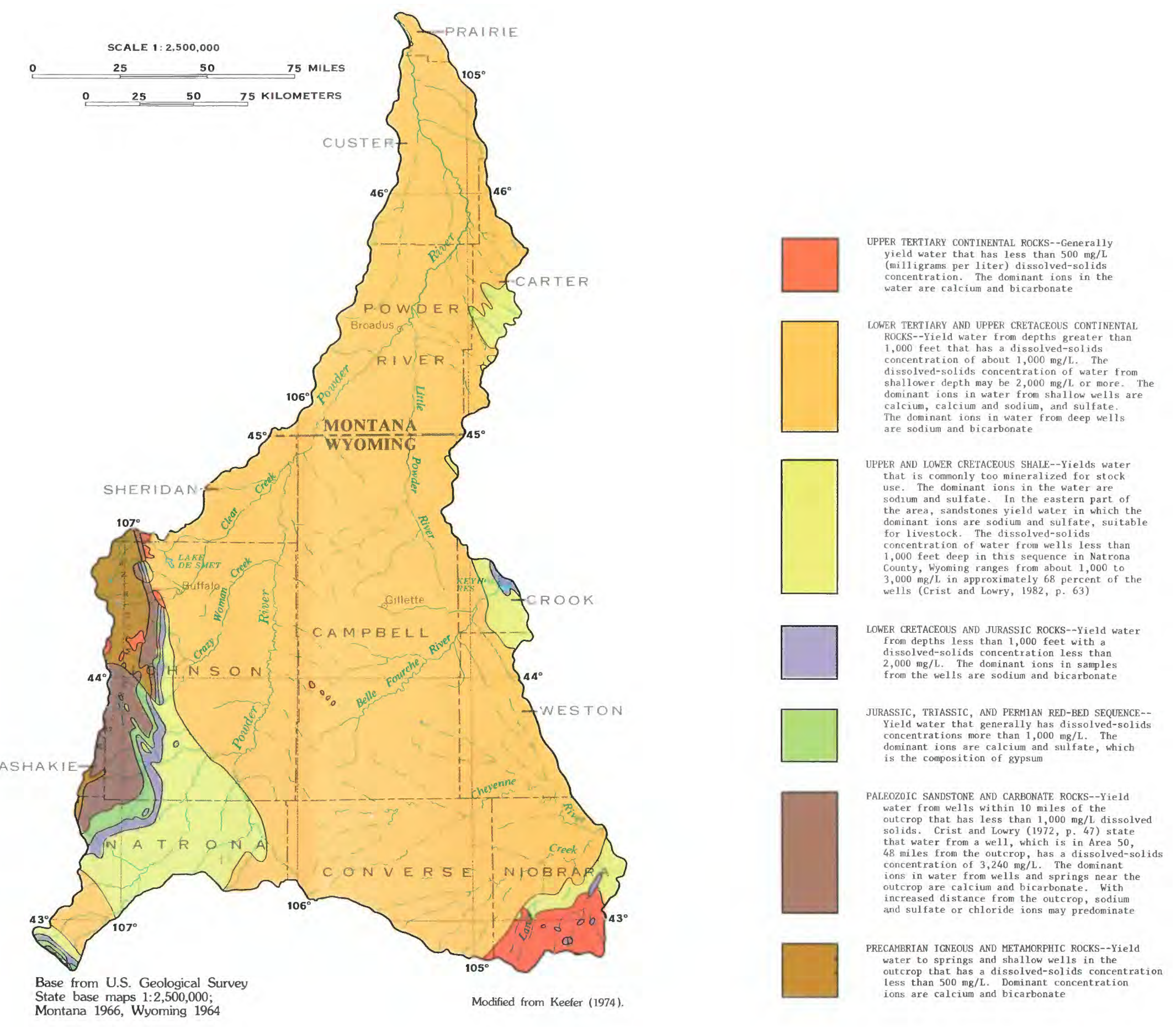

Figure 8.4.3-3 Summary of chemical quality of ground water. 



\section{National Water-Resource Data and Information are Available from Four Sources at the Federal Level}

\section{Water data are collected in coal areas by a large number of organizations in response to a wide variety of missions and needs.}

Three activities within the U.S. Geological Survey help identify and improve access to the vast amount of existing water data.

(1) The National Water Data Exchange (NAWDEX) indexes the water data available from more than 400 organizations and serves as a central focal point to help those in need of water data to determine what information already is available.

(2) The National Water Data Storage and Retrieval System (WATSTORE) serves as the central repository of water data collected by the U.S. Geological Survey and contains large volumes of data on the quantity and quality of both surface and ground waters.

(3) The Office of Water Data Coordination
(OWDC) coordinates Federal water-data acquisition activities and maintains a "Catalog of Information on Water Data." To assist in identifying available water-data activities in coal provinces of the United States, special indexes to the catalog are being printed and made available to the public.

The U.S. Environmental Protection Agency operates a Water Quality Control Information System which includes a data base called STORET. This data base is used for the STOrage and RETrieval of data relating to the quality of water in waterways within and contiguous to the United States.

More detailed explanations of these four activities are given in sections 9.2, 9.3, 9.4, and 9.5. 


\subsection{WATER-DATA SOURCES--Continued \\ 9.2 National Water Data Exchange (NAWDEX)}

\section{NAWDEX Simplifies Access to Water Data}

\section{The National Water-Data Exchange (NAWDEX) is a nationwide program managed by the U.S. Geological Survey to assist users of water data or water-related data in identifying, locating, and acquiring needed data.}

NAWDEX is a national confederation of wateroriented organizations working together to make their data more readily accessible and to facilitate a more efficient exchange of water data.

Services are available through a Program Office located at the U.S. Geological Survey's National Center in Reston, Virginia, and a nationwide network of Assistance Centers located in 45 States and Puerto Rico, which provide local and convenient access to NAWDEX facilities (see fig. 9.2-1). A directory (Edwards, 1980) is available on request that provides names of organizations and persons to contact, addresses, telephone numbers, and office hours for each of these locations.

NAWDEX can assist any organization or individual in identifying and locating needed water data and referring the requestor to the organization that retains the data required. To accomplish this service, NAWDEX maintains a computerized Master Water-Data Index (fig. 9.2-2), which identifies sites for which water data are available, the type of data available for each site, and the organization retaining the data. A Water Data Sources Directory (fig. 9.2-3) also is maintained that identifies organizations that are sources of water data and the locations within these organizations from which data may be obtained. In addition NAWDEX has direct access to some large water-data bases of its members and has reciprocal agreements for the exchange of services with others.

Charges for NAWDEX services are assessed at the option of the organization providing the requested data or data service. Search assistance services are provided free by NAWDEX to the greatest extent possible. Charges are assessed, however, for those requests requiring computer cost, extensive personnel time, duplicating services, or other costs encountered by NAWDEX in the course of providing services. In all instances, charges assessed by NAWDEX Assistance Centers will not exceed the direct costs incurred in responding to the data request. Estimates of cost are provided by NAWDEX upon request and in all instances where costs are anticipated to be substantial.

For additional information concerning the NAWDEX program or its services contact:

Program Office
National Water Data Exchange (NAWDEX)
421 National Center
12201 Sunrise Valley Drive
Reston, VA 22092
Telephone: (703) 860-6031
or FTS 928-6031
Hours: 7:45 - 4:15 EST
District Chief, WRD
U.S. Geological Survey
P.O. Box 1125
Cheyenne, WY 82003
Telephone: (307) 772-2153
FTS 328-2153
District Chief, WRD
U.S. Geological Survey
Federal Building, Drawer 10076
Helena, MT 59626
Telephone: (406) 449-5263
FTS 585-5263




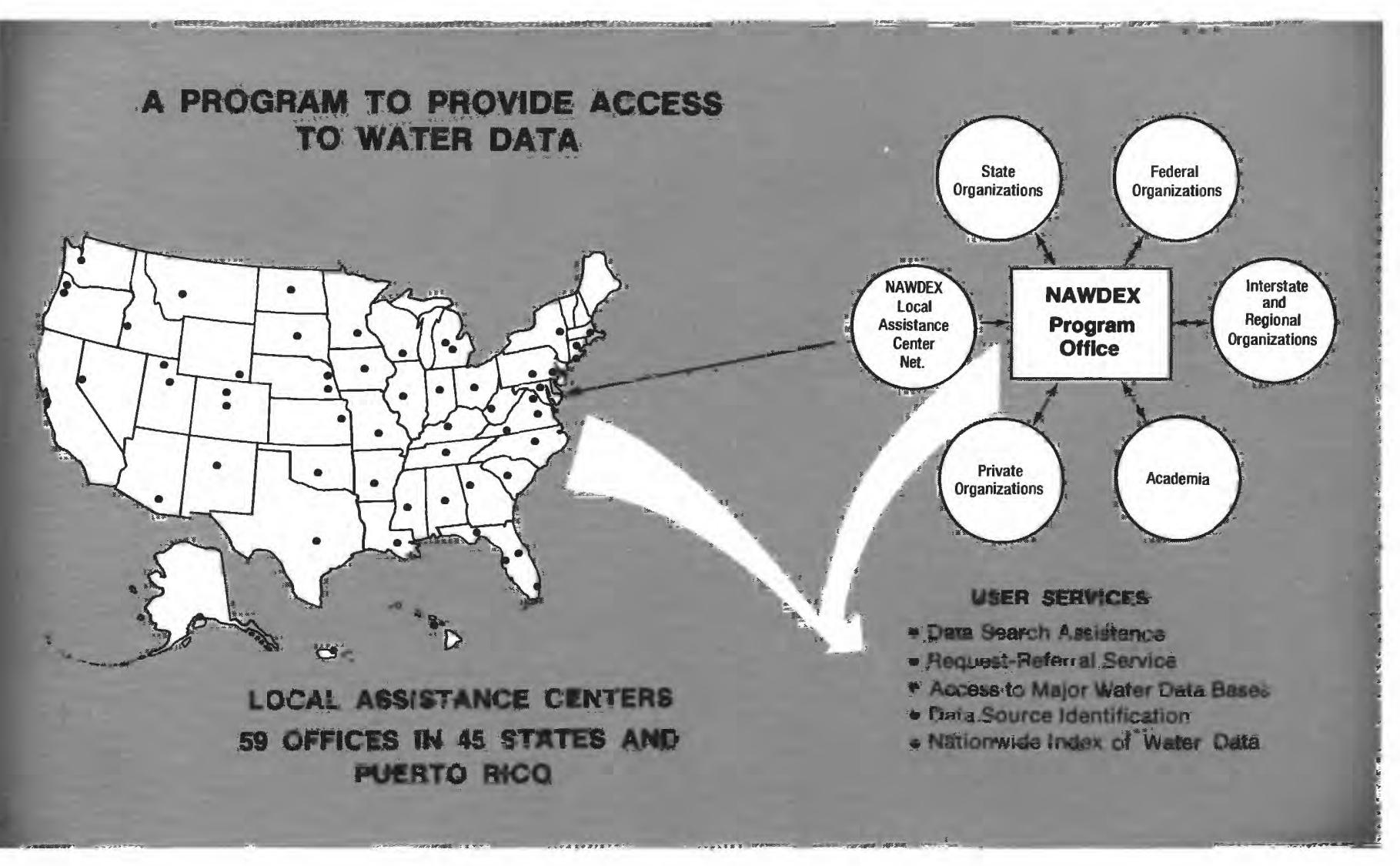

Figure 9.2-1 Function of NAWDEX Program Office.

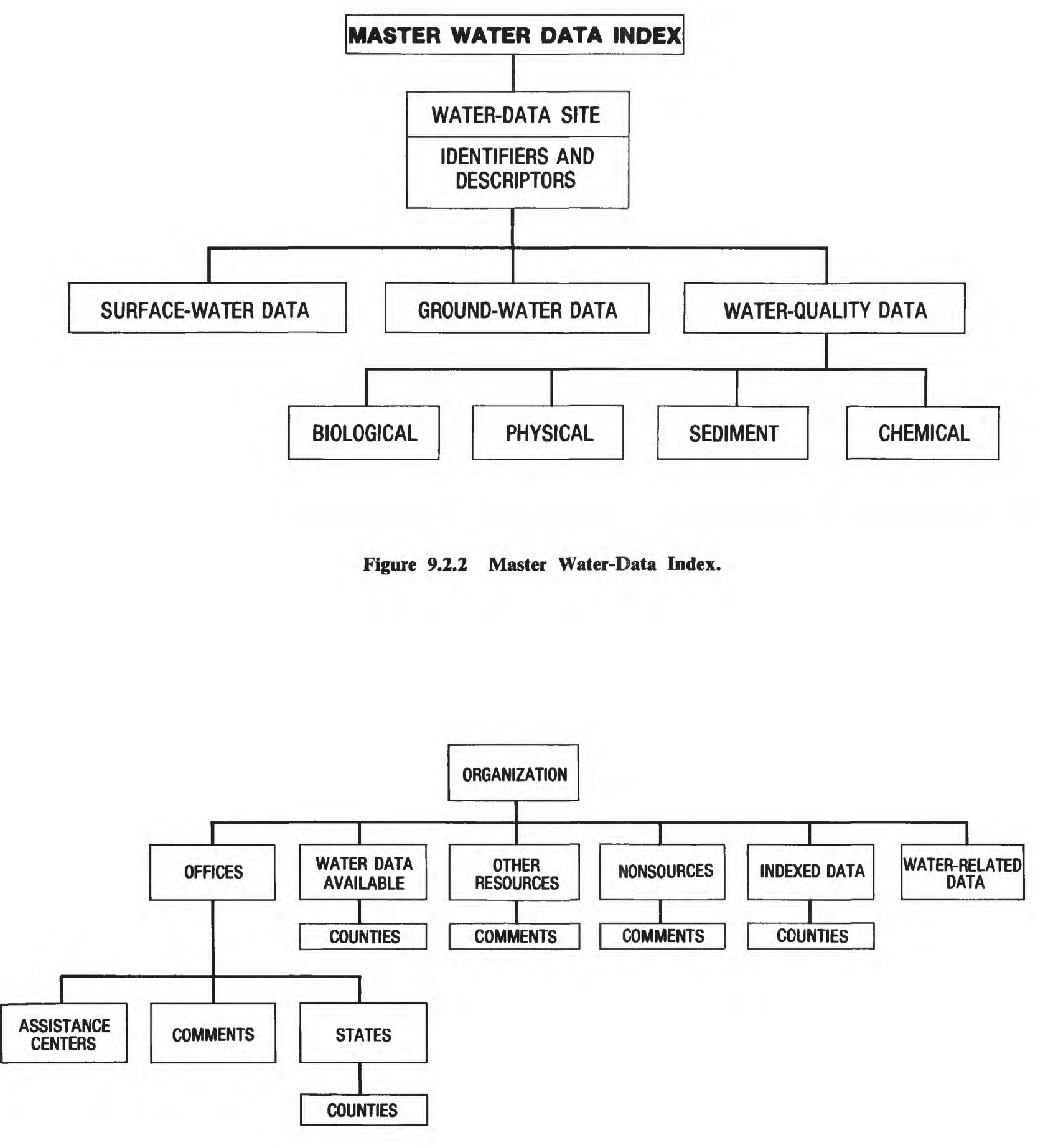

Figure 9.2-3 Water Data Sources Directory. 


\section{WATSTORE Automated Data System}

The National Water Data Storage and Retrieval System (WATSTORE) of the U.S. Geological Survey provides computerized procedures and techniques for processing water data and provides effective and
of data-releasing activities.

WATSTORE was established in November 1971 and efficient management of its data-releasing activities. The system is operated and maintained on the central computer facilities of the Survey at its National Center in Reston, Virginia. Data may be obtained from WATSTORE through the Water Resources Division's 43 district offices. General inquiries about WATSTORE may be directed to:

Chief Hydrologist

U.S. Geological Survey 437 National Center
Reston, VA 22092

U.S. Geological Survey Water Resources Divisio P.O. Box 1125

Cheyenne, WY 82003

U.S. Geological Survey Water Resources Division
Federal Building, Drawer 10076

Helena, MT 59626

The Geological Survey currently (1983) collects data at approximately 17,000 stage- or discharge-gaging at approximately 17,000 stage- or discharge-gaging water-level observation wells, and 7,400 groundwater quality wells. Each year many water-dat collection sites are added and others are discontinued; thus, large amounts of diversified data, both massed by the Survey's

The WATSTORE system consists of several files in which data are grouped and stored by common characteristics and grouped and stored by common system also is designed to allow for the inclusion of additional data files as needed. Currently, files are maintained for the storage of: (1) Surface-water quality-of-water, and ground-water data measured on a daily or continuous basis; (2) annual peak value for streanflow stations; (3) (2) anical analyses fo measured more frequently than daily; and (5) geologic and inventory data for ground-water sites. In addition, an index file of sites for which data are stored in the system is also maintained (fig. 9.3-1). A brief description of each file is as follows.

Station Header File: Information pertinent to he identification of nearly 220,000 sites is contained in this file. Al sites for which data are stored in the Daily Values WATSTORE are indexed in this file.

Daily Values File: All water-data parameters measured or observed either on a daily or on continuous basis and numerically reduced to daily values are stored in this file. Instantaneous measurements at fixed-time intervals, daily mean values, and statistics such as daily maximum and minimum values also may be stored. This file currently contain more than 200 millon daily values including data on temperatures, specific conductance, sediment concentrations, sediment discharges, and ground-water levels.

Peak Flow File: Annual maximum (peak) at surface-water sites comprise this file, which currently contains more than 400,000 peak observations.

Water Quality File: Results of more than 1.4 million analyses of water samples are contained in 185 different constituents and physical properties that describe the chemical, physical, biological, an radiochemical characteristics of both surface and ground waters.

Unit Values File: Water parameters measured on 
a schedule more frequent than daily are stored in this file. Rainfall, stream discharge, and temperature data are examples of the types of data stored in the Unit Values File.

Ground-Water Site-Inventory File: This file is maintained within WATSTORE independent of the files discussed above, but it is cross-referenced to the Water Quality File and the Daily Values File. It contains inventory data about wells, springs, and other sources of ground water. The data included are site location and identification, geohydrologic chracteristics, well-construction history, and one-time on site measurements such as water temperature. The file is designed to accomnodate 225 data elements

All data files of the WATSTORE system are and managed on the central computer facilities of the Geological Survey at its National Center. However, data may be entered into and retrieved from WATSTORE at a number of locations that are part of a nationwide telecommunication network.

Remote Job Entry Sites: Almost all Water Resources Division's district offices are equipped with the WATSTORE system. These terminals allow each site to enter data into or retrieve data from the system within an interval of several minutes to overnight, depending upon the priority placed on the request. The number of remote job-entry sites is increased as the need arises.

Digital Transmission Sites: Digital recorders are used at many field locations to record values fo parameters such as river stages, conductivity, water concentration. Data are recorded on 16-channe paper tape; the tape is removed from the recorder, and the data are transmitted over telephone lines to the receiver at Reston, Va. The data are re-recorded on magnetic tape for use on the central computer. Extensive testing of satellite data-collection platforms indicates their feasibility for transmitting realtime hydrologic data on a national scale. Batteryoperated radios are used as the communication lin to the satellite. About 500 data-relay stations are being operated curr sources Division.

Central Laboratory System: The Water Resources Division's two located in Denver, Colo., and Atlanta, Ga., analyze more than 150,000 water samples per year. These laboratories are equipped to automatically perform chemical analyses ranging from determinations of simple inorganic substances, such as chloride, to complex organic compounds, such as pesticides. A each analysis is completed, the results are verified by acring to the central computer facilities to be stored in the Water Quality File of WATSTORE.

Water data are used in many ways by decisionmakers for the management, development, and monitoring of our water resources. In addition to its data processing, storage, and retrieval capabilities, WATSTORE can provide a variety of useful
products ranging from simple tables of data to comproducts ranging from simple tables of data to complex statistical analyses. A minimal fee, plus the product, is charged to the requestor.

Computer-Printed Tables: Users most often request data from WATSTORE in the form of tables printed by the computer. These tables may contain lists of actual data or condensed indexes that indicate the availability of data stored in the files. A variety of formats is available to display the many types of data.

Computer-Printed Graphs: Computer-printed graphs for the rapid analysis or display of data ar grams are available to produce bar graphs (histograms), line graphs, frequency-distributio curves, X-Y point plots, site-location map plots, and other similar items by means of line printers.

Statistical Analyses: WATSTORE interfaces with a proprietary statistical package called SAS (Statistical Analysis System, 1976) to provide extensive analyses of data such as regression analyses, tions.

Digital Plotting: WATSTORE also makes use of software systems that prepare data for digital plotting on peripheral offline plotters available at the central computer site. Plots that can be obtained include hydrographs, frequency-distribution curves, $\mathrm{X}-\mathrm{Y}$ point plots, contour plots, and three-dimensionplots.

Data in Machine-Readable Form: Data stored in form for use con be to user-written computer programs. These data are available in the standard format of the WATSTORE system or in the form of punched cards or card images on magnetic tape.

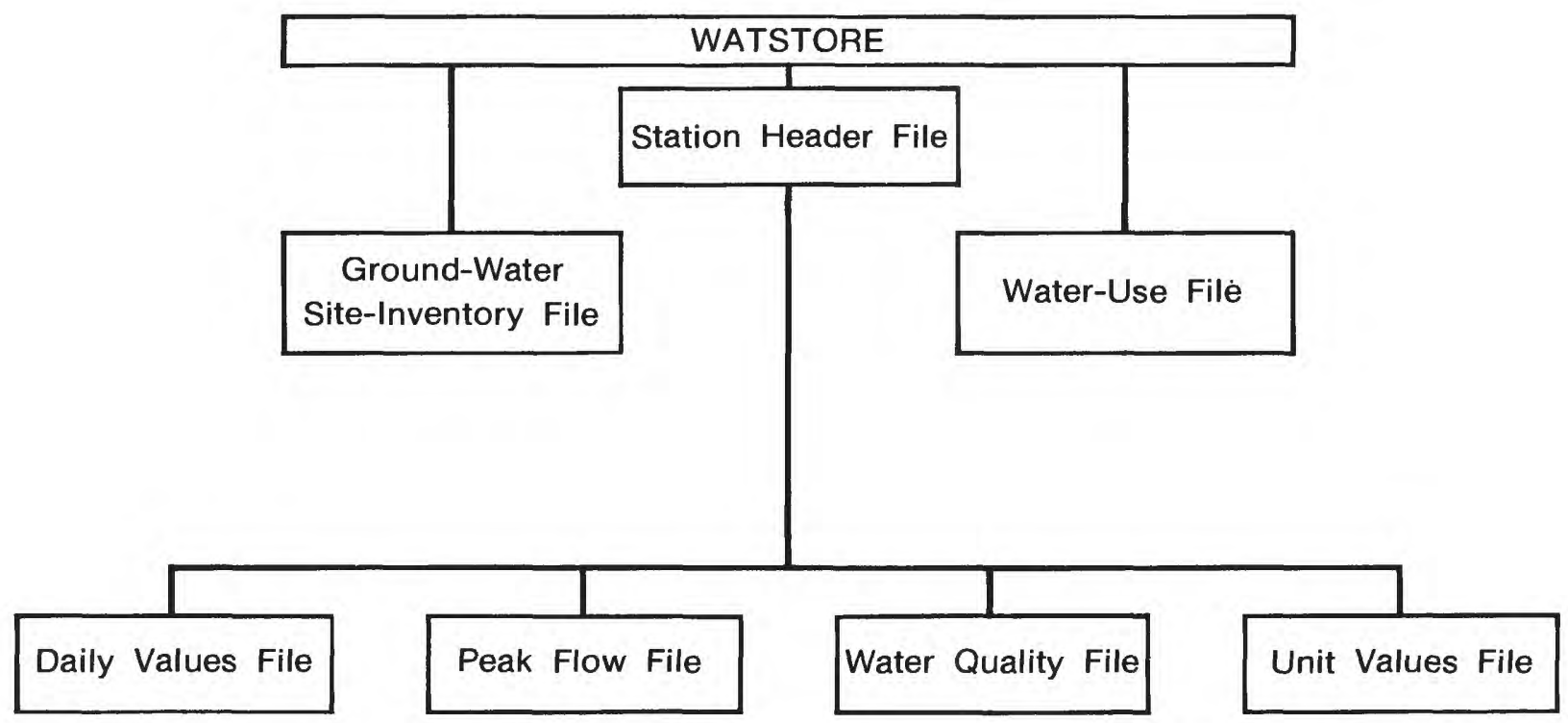

Figure 9.3-1 WATSTORE file system 


\section{Water Data Indexed for Coal Provinces} A special index, "Index to Water-Data Activities in Coal Provinces of the
United States," has been published by the U.S. Geological Survey's Office of Water Data Coordination (OWDC).

The "Index to Water-Data Activities in Coal Provist those involved ind develos. Was prepared to resulating the Nation's coal resources by providing information on the availability of water-resources data in the major coal provinces of the United States. It is derived from the "Catalog of Information on Water Data," which is a computerized information file about water-data acquisition activities in the United States, and its territories and possessions, with some international activities included.

This special index consists of five volumes (fig. 9.41): Volume 1, Eastern Coal Provin Great Plains and Rocky Mountain Coal Provinces: Volume IV, Gulf Coast Coal Province; and Volume V, Pacific Coast and Alaska Coal Provinces. The nformation presented will aid the user in obtaining data for evaluating the effects of coal mining on water resources and in developing plans for meeting additional water-data needs. The report does not contain the actual data, rather, it provides information that will enable the user to determine if needed

Each volume of this special index consists of four parts: Part A, Streamflow and Stage Stations; Part B, Quality of Surface-Water Stations; Part C, Quality of Ground-Water Stations; and Part D, Areal Investigations and Miscellaneous Activities. Information given for each activity in Parts A-C includes:
(1) The identification and location of the station, (2) the major types of data collected, (3) the frequency stored and (5) the the or organization the activity. Part D summarizes areat hydrologic investigations and water-data activities not included in the other parts of the index. The agencies that submitted the information, agency codes, and the number of activities reported by type are listed in a table.

Those who need additional information from the Catalog file or who need assistance in obtaining Cater data can who ned a Nation

Further information about the index volumes and their availability may be obtained from:

U.S. Geological Survey P.O. Box 1125 Cheyenne, WY 82003 Telephone: (307) 772-2153 FTS 328-2153

U.S. Geological Survey Federal Building. Drawer 10076 Helena, MT 59626 Telephone: (406) 449-5263 FTS 585-5263 


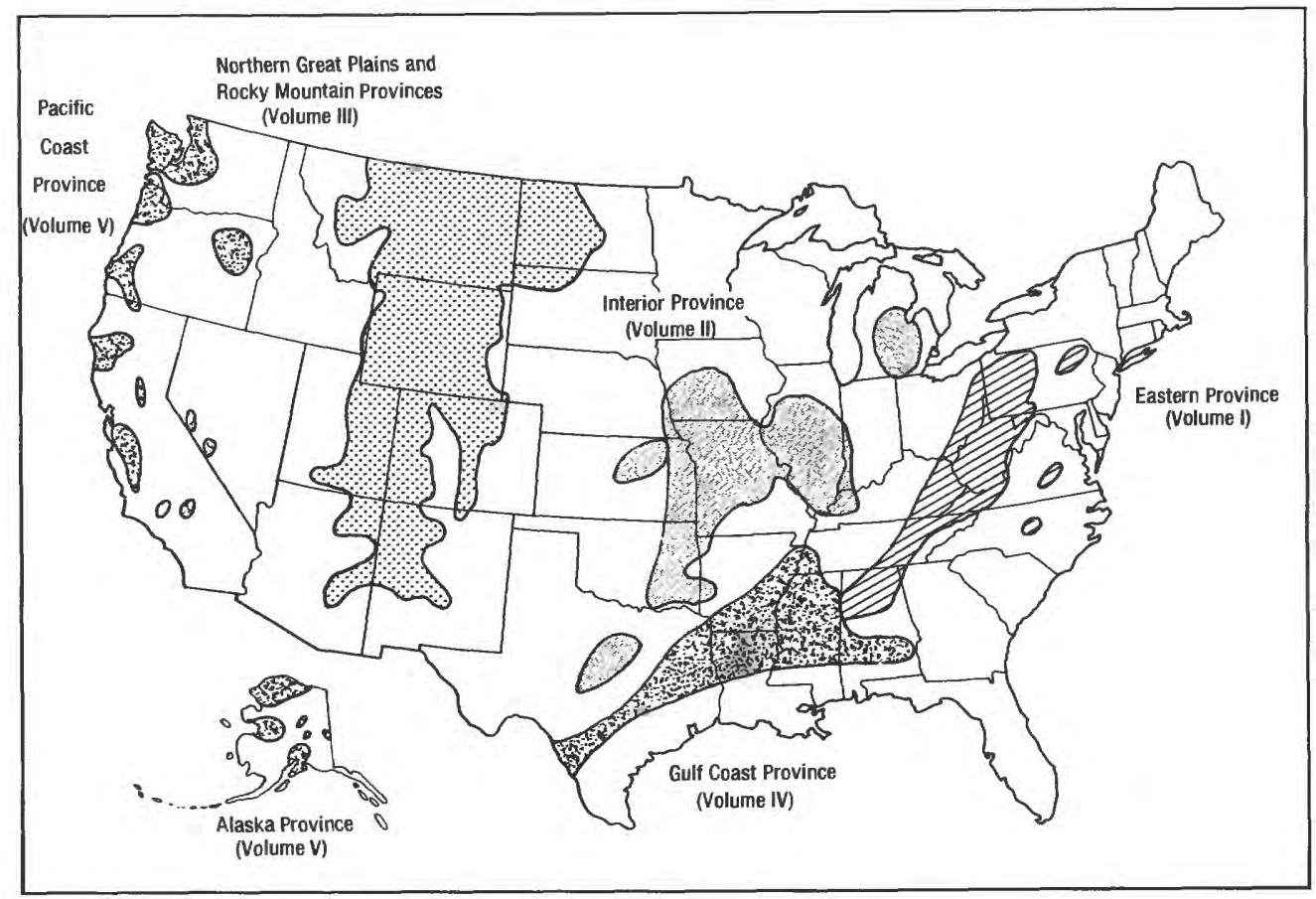

Figure 9.4-1 Index volumes and related provinces. 


\title{
9.0 WATER-DATA SOURCES--Continued \\ 9.5 STORET
}

\section{STORET is U.S. Environmental Protection Agency Computerized Water-Data System}

\author{
STORET is the computerized water-data system that is maintained by the \\ U.S. Environmental Protection Agency; the system is used to store many \\ kinds of water-quality data.
}

STORET is a computerized water-data system maintained by the U.S. Environmental Protection Agency for the STOrage and RETreival of data relating to the quality of water in waterways within and contiguous to the United States. The system is used to store data on water quality, water-quality standards, point sources of pollution, pollutioncaused fish kills, waste-abatement needs, implementation schedules, and other water-quality related information. The Water Quality File is the most widely used file in the STORET data base.

The data in the Water Quality File are collected through cooperative programs involving the Environmental Protection Agency, State water pollution control authorities, and other governmental agencies. The U.S. Forest Service, the U.S. Army Corps of Engineers, the U.S. Bureau of Reclamation, and the Tennessee Valley Authority all use STORET's Water Quality File to store and retrieve data collected through their water-quality monitoring programs. Data from the U.S. Geological Survey's water-quality file in WATSTORE are automatically copied into STORET on a periodic basis.
There are 1,800 water-quality parameters defined within STORET's Water Quality File. In 1976 data from more than 200,000 unique collection points in the United States were stored in the system. The groups of parameters and number of observations that are in the Water Quality File are shown in figure 9.5-1.

State, Federal, interstate, and local government agencies can become STORET users. Information on becoming a user of the system can be obtained by contacting the Environmental Protection Agency. The contact for this area is:

Environmental Services Division

U.S. Environmental Protection Agency 1860 Lincoln Street, Suite 103 Denver, CO 80295 Telephone: (303) 844-2226

Source: Handbook, Water Quality Control Information System (STORET), U.S. Environmental Protection Agency, Office of Water and Hazardous Materials, Washington, D.C. 20460. 


\subsection{SUPPLEMENTAL INFORMATION FOR AREA 50}

10.1 Hydrologic Studies by the Geological Survey

\section{Many Active Investigations in Area 50}

\section{The Wyoming and Montana Districts of the U.S. Geological Survey have many active hydrologic studies that will produce information about the water resources of Area 50; some are site-specific in scope and others are statewide or regional.}

The U.S. Geological Survey projects described below are either active (data collection and analysis in progress) or complete except for report (final report in preparation). Projects for which the final reports are listed in the References (section 11.0) of this report are not described below. For each project listed, the Geological Survey project number, purpose, and geographic location are given. For additional information see Green (1983) and Roberts (1983).

\section{WYOMING AND MONTANA}

1. Surface-Water Stations (WY001 and MT001). A network of surface-water stations is operated and maintained, in order to collect, store, and publish short-term and long-term stream flow data for evaluation, planning, and management of surface-water resources. Statewide, Wyoming and Montana.

2. Ground-Water Stations (WY002 and MT002). A network of ground-water wells is operated and maintained in order to collect, store, and publish short-term and long-term water-level data for evaluation, planning, and management of ground-water resources. Statewide, Wyoming and Montana.

3. Water-Quality Stations (WY003 and MT003). A network of water-quality stations is operated and maintained, in order to collect, store, and publish short-term and long-term chemical-, physical-, and biological-quality data for surface and ground waters for evaluation, planning, and management of water resources. Statewide, Wyoming and Montana.

4. Sediment Stations (WY004 and MT004). A network of sediment stations is operated and maintained, in order to collect, store, and publish data, including concentration, discharge, and particle size of sediment transported by rivers and streams, for evaluation, planning, and management of water resources. Statewide, Wyoming and Montana.
5. Northern Great Plains Regional Aquifer-System Analysis in Parts of Montana, North Dakota, South Dakota, and Wyoming (CR230, WY049, and MT067). Assess the availability of ground water through a detailed study of the hydrologic characteristics of the major aquifers and develop predictive models to evaluate selected ground-water-management alternatives. Northeastern Wyoming, eastern Montana, North and South Dakota.

\section{WYOMING}

1. Flood Investigations in Wyoming (WY010). Collect flood information at partial-record stations and other sites; define the magnitude and frequency of floods using all available data. Statewide.

2. Precipitation, Infiltration, and Runoff Relations for Small Basins in Wyoming (WY054). Define infiltration-rate curves for soils and other surficial materials for use in a rainfall-runoff model, in order to provide a method for estimating flood discharges on small streams. Statewide.

3. Streamflow Characteristics of Energy-Mineral Areas in Wyoming (WY056). Develop improved techniques and relations for estimating monthly and annual runoff; refine relations for estimating peak flows. Statewide.

4. Biological Communities of Small Streams in Wyoming (WY057). Define the biologic communities and their interrelated stream environments; evaluate aquatic organisms as a means of identifying alluvial-valley floors; assess potential for re-establishment of biologic communities following disturbance. Northeastern Wyoming.

5. Ground-Water Hydrology of the Southern Powder River Uranium District, Wyoming (WY060). Define the existing hydrologic system and evaluate impacts of 
uranium exploration and development. Northeastern Wyoming.

6. Potentiometric Maps of Shallow Aquifers in the Powder River Basin, Northeastern Wyoming (WY062). Prepare maps of potentions Northeastern Wyoming

7. Sediment Yield From Natural and Reclaimed Small Ephemeral Stream Basins in Wyoming (WY066). Relate sediment yield to rainfall and runoff; evaluate possible changes in the relation due to surface mining; determine the importance of channel erosion and slope wash as sediment sources, investigate possible sedimentWyoming.

8. Low Flow of Streamsin the Powder River Structural Basin, Wyoming (WY067). Analyze low-flow of water available without the use of artificial storage. Northeastern Wyoming.

9. Chemical Quality of Surface Water in the Powder River, Green River, Great Divide, and Hanna Basins, Wyoming (WY071). Summarize statistically the surfacewater quality data previously collected in the principal coal areas and recommend future water-quality datacollection activites in these

10. Recharge of Shallow Aquifers Through Ephemeral Stream Channels in Wyoming (WY073). Determine the relationship of water in the alluvium to evaluate the use of streamflow hydrographs to determine seepage from ephemeral streams. Northeastern Wyoming.

11. Ground-Water Quality in Wyoming (WY074). Assemble and summarize existing information; assess quality of water of major aquifers and for evaluating future changes in water quality. Statewide.

12. The Fluvial System in Energy-Minerals Areas of Wyoming (WY076). Describe how the fluvial systems function; determine the effects of energy-related developments on the stability of stream channels and drainage networks. Notheastern, south-central, and southwestern Wyoming.
13. Hydrologic Properties of the Alluvial Deposits Along the Powder River Between Sussex, Wyoming and Moorhead, Montana (WY078). Describe the hydrology of the alluvial deposits, determine the potential for develop-

14. Evaluation of the Ground-Water ObservationWell Program for the Powder River Basin and Adjacent Area, Northeastern Wyoming (WY079). Evaluate the existing observation-well program; recommend a revised
program to monitor ground-water levels. Northeastern Wyoming.

15. Evaluation of the Individual and Cumulative Impacts of Mine Operations on the Surface and Ground Wyomin (WY080) No Wyoming (WY080). Northeastern Wyoming.

\section{MONTANA}

1. Water-Use Data System for Montana (MT007) Develop and maintain a water-use data system that is responsive to users at State and national levels. Statewide.

2. Peak-Flow Analysis for Small Drainage Areas, Montana (MTO10. Obtain adequate data to enable definition of the magnitude and frequency of floods to be expected from any

3. Bridge-Site Investigations in Montana (MT023). Provide the Montana Department of Highways with sufficient data to permit the most economical and hydraulically safe bridge or culvert as possible. Statewide.

4. Special Investigations, Montana (MT030). Assist Statewide.

5. Effects of Mining and Related Activities on the Shallow Ground-Water System (MT048). Define the ground-water flow systems above the Bearpaw Shale; on the hydrictive models to assess the effects of ogic system. Southeastern Montana.

6. Structure, Potentiometric-Surface, and Quality-of作 tral and Eastem Montana (MTO56). Complile data from wells and test holes; prepare maps describing the altitude and configuration of the top of the aquifer, potentiometric surface, and quality of water. Central and eastem

7. Water-Resources Monitoring, Northern Powder River Coal Region, Montana (MT059). Determine detect and document any changes in the system as a result of coal mining. Southeastern Montana.

8. Limnological Reconnaissance of Small Reservoirs in Montana (MT064). Characterize the present physical, chemical, and biological conditions in selected reservoirs; evaluate the suitability of the reservoirs for various uses. Eastern Montana.
9. Streamflow Characteristics Related to Channel Geometry in Ephemeral Streams, Montana (MTO70). Collect data on chemical characteristics, develop equations relating channelgeactry to strentics;

10. Regional Analyses of Surface-Water Quality in the Fort Union Coal Region, Montana (MT072). Compile and present data in a semi-interpretive format: review and modify the data-monitoring network. Eastern Montana. 
10.0 SUPPLEMENTAL INFORMATION FOR AREA 50--Continued

10.2 List of Other Agencies

Resource Information Available from Other Agencies

Water, land, and coal resources in Area 50 are the concern of many State and Federal agencies; these agencies are important sources of information.

The names and addresses of principal State and Federal agencies that have additional information about water, land, and coal resources are listed below. Other agencies also have water-related misstruction of water projects, such as reservirs, with the use of water for specific purposes, such a recreation, are not included, unless they also serve as an important source of water-resources information. Also not included are coal and oil companies operating in the area that have nonproprietary informatio

\section{FEDERAL AGENCIES}

Wyoming State Office

U.S. Bureau of Land Managemen P.O. Box 1828

Montana State Office

U.S. Bureau of Land Management

Granite Tower, 222 N. 32n
Billings, MT 59101

Casper District Office

Management 951 Rancho Road
Casper, WY 82601

Miles City District Office

U.S. Bureau of Land Managemen Miles City, MT 59301

Wyoming State Office

U.S. Soil Conser P.O. Box 2440 Casper, WY 82602

Montana State Office

.

ost Office and Federal Bldg. Bozeman, MT 59715

U.S. Department of Energy P.O. Box 256

Grand Junction, CO 81502

Western Section, Branch o Coal Resources

U.S. Geological Survey

Mail Stop 972, Box 25046

Denver Federal Center
Lakewood, CO 80225

Surveillance and Analysis Division S. Environmental Protection Agency 1860 Lincoln Str Denver, CO 80295

Western Technical Center Office of Surface Mining 1020 - 15th Street

Thunder Basin National Grassland U.S. Forest Service 809 South 9th Street
Douglas, WY 82633

Northern Regional Office U.S. Forest Service and Courthouse 200 E. Broadway Street Missoula, MT 59801

STATE AGENCIES

Wyoming State Engineer Herschler Building Cheyenne, WY 82002

Wyoming State Geologist Box 3008, University Laramie, WY 82071

Water Quality Division yoming Department of Environmental Quality 
Herschler Building

Cheyenne, WY 82002

Land Quality Division Wyoming Department of Environmental Quality

Herschler Building

Cheyenne, WY 82002

Wyoming Water Research Center University of Wyoming

Box 3067, University Station Laramie, WY 82071

Montana Bureau of Mines and Geology

Montana College of Mineral

Science and Technology

Butte, MT 59701

Water Resources Division

Montana Department of Natural

Resources and Conservation

32 South Ewing

Helena, MT 59601

Energy Division

Montana Department of Natural

Resources and Conservation

25 South Ewing

Helena, MT 59601

\author{
Water Quality Bureau \\ Montana Department of Health \\ and Environmental Sciences \\ Cogswell Building \\ Helena, MT 59601 \\ Montana Water Resources \\ Research Center \\ Montana State University \\ Bozeman, MT 59717 \\ Montana Department of State Lands \\ 1625 - 11th Avenue \\ Helena, MT 59601

\section{MAPS}

Several of the agencies listed above have resource maps available. Water-resource, geologic, coalresource, land-use, topographic, and other naturalresource maps of the U.S. Geological Survey are available for purchase from:

Western Distribution Branch

U.S. Geological Survey

Box 25286, Denver Federal Center

Lakewood, CO 80225 
10.3 Index of Surface-Water Stations

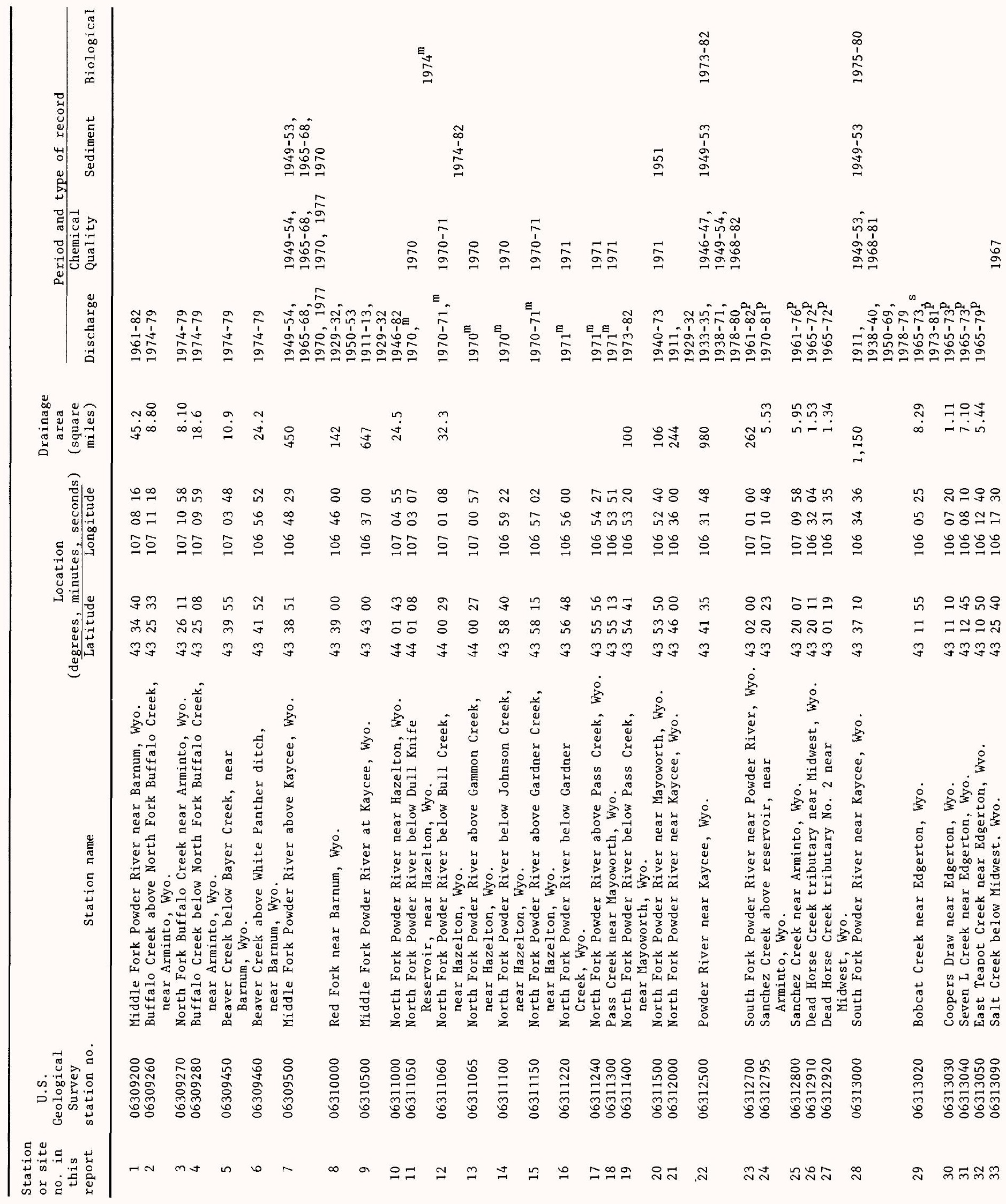




\subsection{SUPPLEMENTAL INFORMATION FOR}

AREA 50--Continued

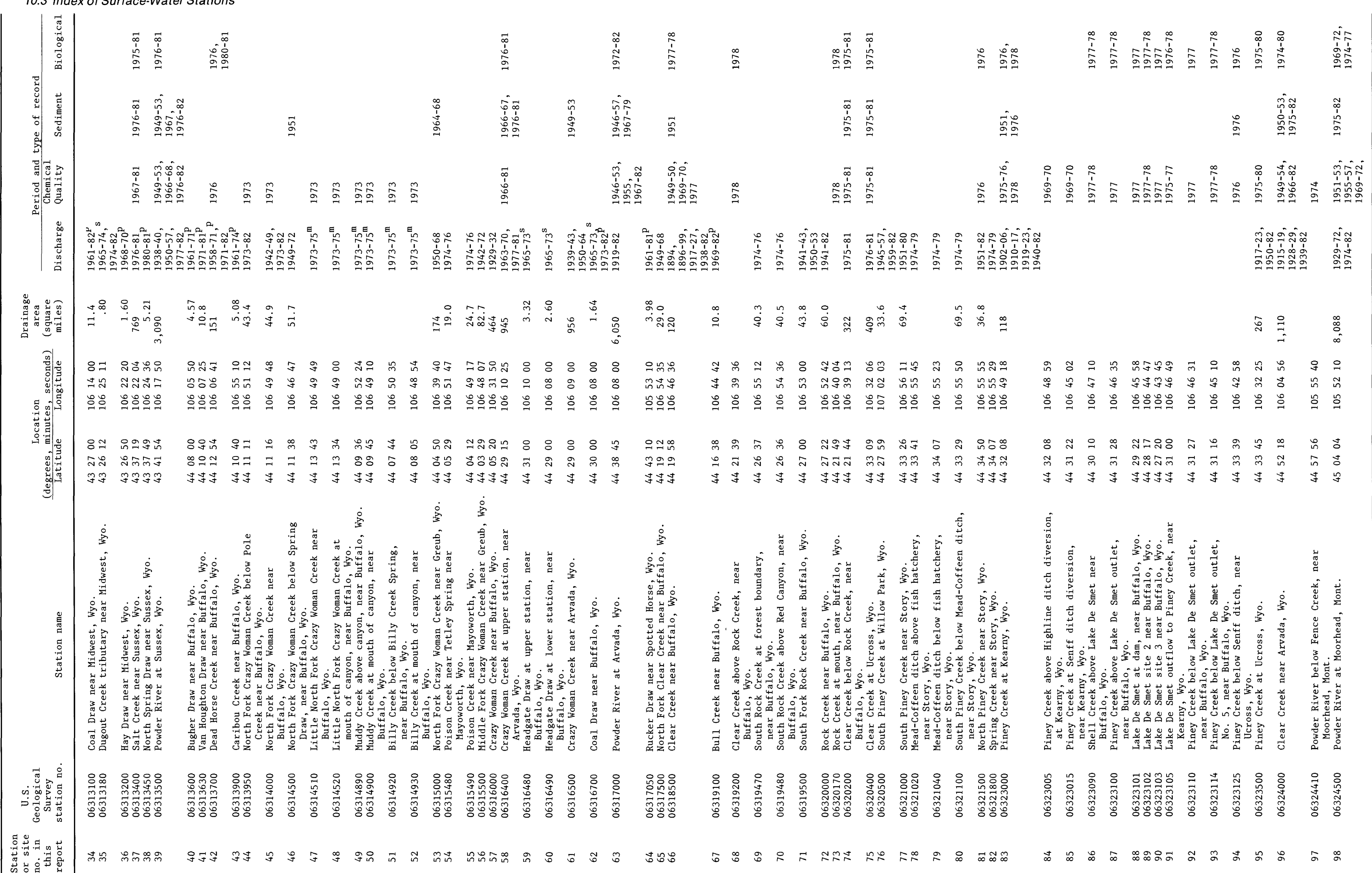

10.0 SUPPLEMENTAL INFORMATION FOR AREA 50--Continued

10.3 Index of Surface-Water Stations 


\subsection{SUPPLEMENTAL INFORMATION FOR}

AREA 50--Continued

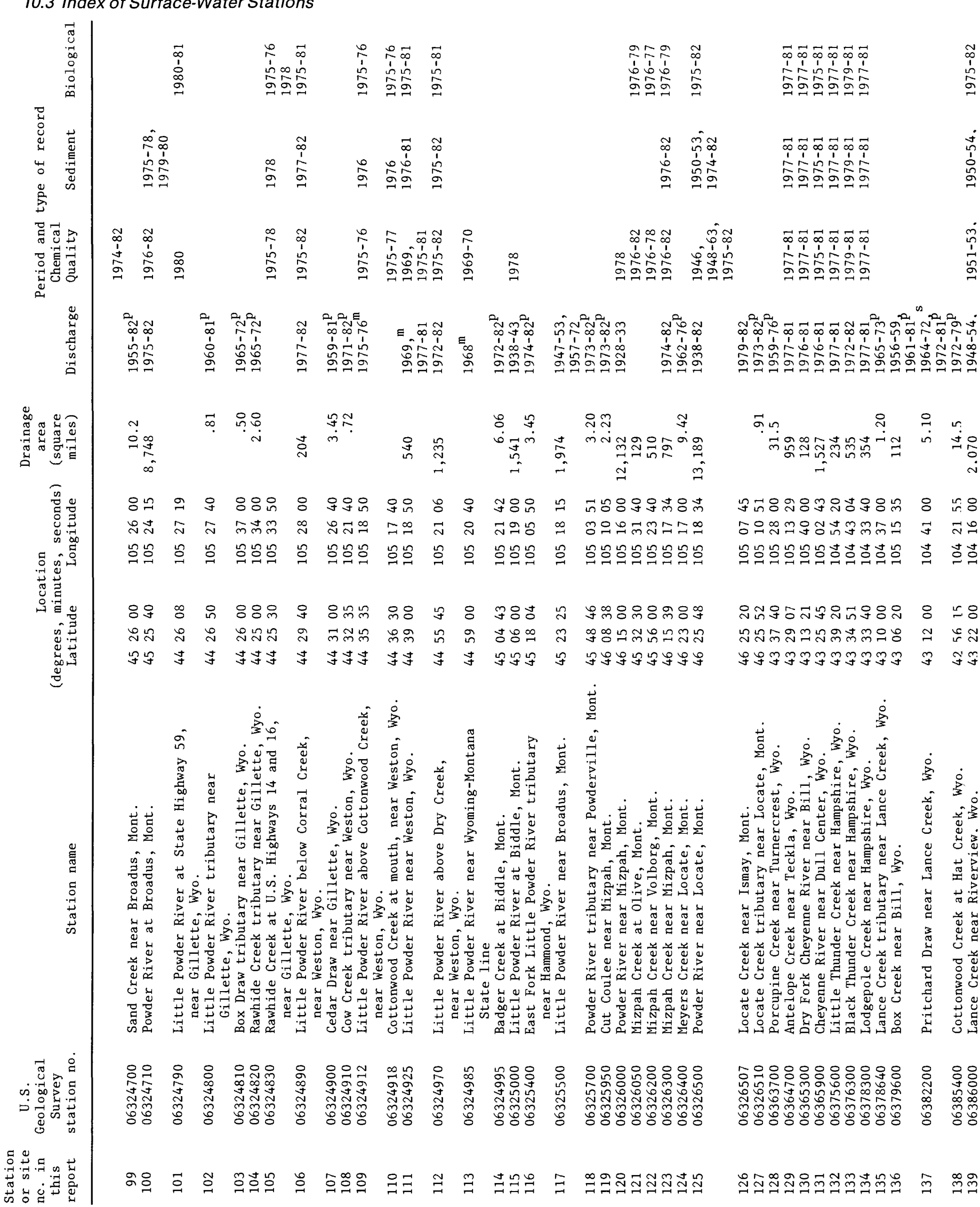




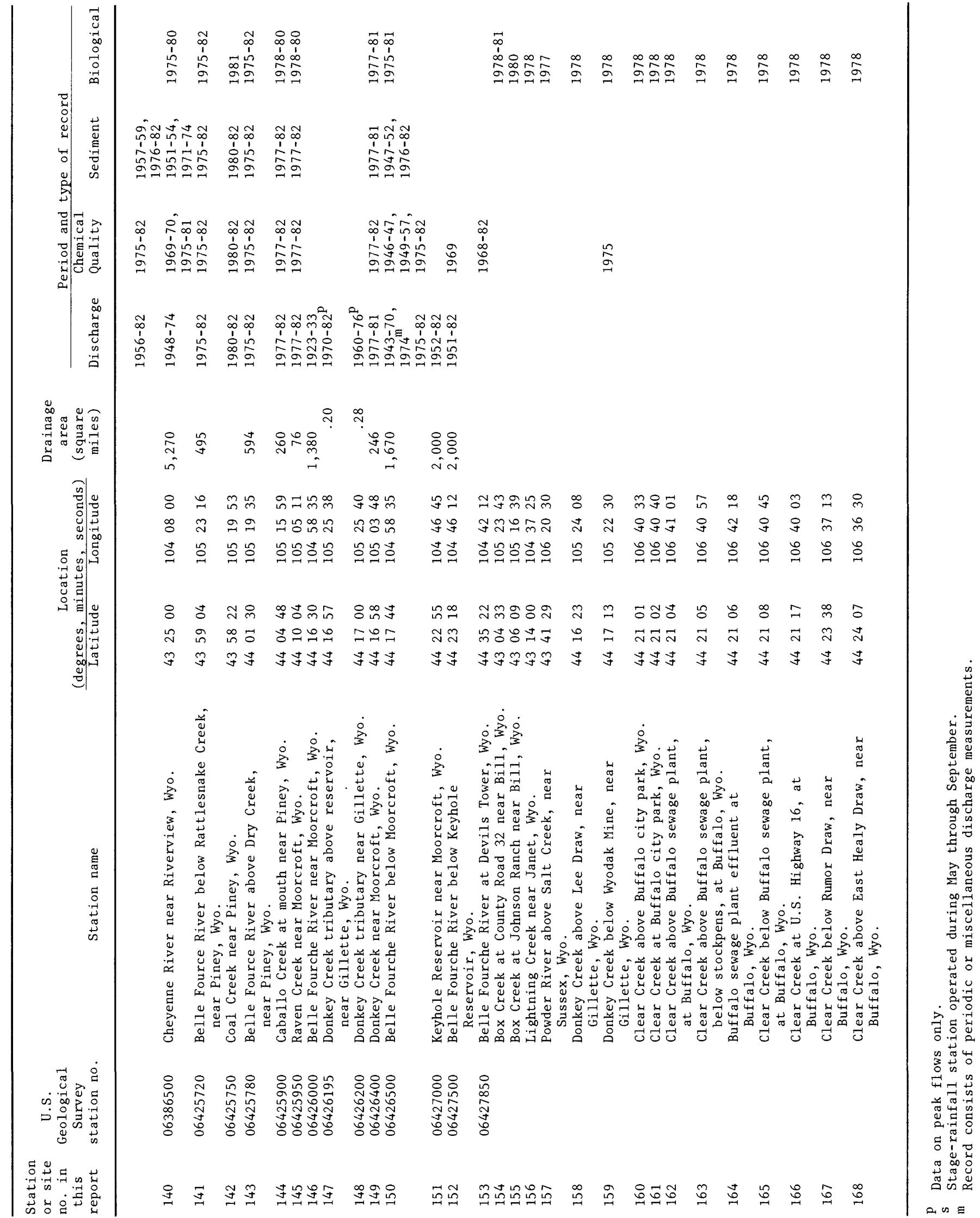




\title{
11.0 REFERENCES
}

11.1 Topic Listing

\section{Bibliography Contains More Than 350 References}

\author{
The scientific literature for Area 50 is extensive; the references \\ listed in this report are summarized by major topic.
}

More than 350 references are listed in section 11.2 , indicating the large amount of scientific information available. Because only about 145 of the references are cited in the text, the references are listed below by major topic. The topics correspond with primary and, in most instances, secondary headings used in this report. Every reference is listed at least once; some twice or more. The classification of the references is not exhaustive-a reference may include useful information about topics other than those for which the reference is listed. For example, the environmental impact statements are listed only under 1.0 INTRODUCTION; these reports commonly contain extensive information related to most of the other topics.

\subsection{INTRODUCTION}

Barrett and others (1980), Clark and others (1982), Davis and Wood (1974), Davis (1976), Davis and Rechard (1977), Deutsch and others (1979), Dunrud and Osterwald (1980), Everett (1979), Gillette Area Groundwater Monitoring Organization and Northeastern Wyoming Chapter, American Institute of Mining Engineers (1982), Greensdale (1980), Hadley and Keefer (1975), Hafen and Hafen (1961), Hudson (1975), Imhoff and others (1976), Jordan and others (1984), Keefer (1976), Keefer and Hadley (1976), Kilpatrick and Matchett (1982), Lagasse and others (1982), Leopold and others (1971), Lowry and Cummings (1966), Lusby and Toy (1976), Mapel (1959), Melancon and others (1979), Narten and others (1983), National Academy of Sciences (1974), Packer (1974), Raynolds, (1868), Rechard and Larson (1982), Rhodes and Stone (1981), Richards (1981), Ringen and others (1979), Slagle and others (1983), Steele and Hillier (1981), University of Wyoming, Black Thunder project research team (1976), U.S. Department of the Interior $(1975,1976,1977 \mathrm{a}, 1977 \mathrm{~b}$, 1977c,1977d, 1979a, 1979b, 1979c, 1979d, 1981a, 1981b, 1982a, 1982b, 1983), U.S. Department of the Interior and Montana Department of State Lands
(1980), U.S. Department of the Interior and others (1974), Van Voast (1974), Walker (1980), Wister (1902).

\subsection{DEFINITION OF TERMS}

Langbein and Iseri (1960), Lohman and others (1972), U.S. Geological Survey (1983a, 1983b), Young and Singleton (1977).

\section{O PHYSIOGRAPHY}

\subsection{Climate}

Cordell (1960), Farnsworth and Thompson (1982), Johnson and Omang (1976), Lowers (1960), Miller and others (1973a, 1973b), National Oceanic and Atmospheric Administration (1973), U.S. Soil Conservation Service (1977).

\subsection{Landforms}

Breckenridge and others (1974), Hammond (1964), Keefer (1974), Lageson and others (1980), Lane and others (1972), Schumm and Hadley (1957), Trimble (1980), Wendell and others (1976).

\subsection{Drainage}

Leopold and Miller (1954), Leopold and others (1964), U.S. Geological Survey (1976a, 1976b).

3.4 Soils

Conner and others (1976), Ebens and Shacklette (1982), Montagne and others (1982), Rankl (1982), Simonson and others (1978), Stephens (1975), U.S. Department of Agriculture (1962, 1975), U.S. Salinity Laboratory Staff (1954), Van Voast and Bremmer (1976), Young and Singleton (1977).

\subsection{Vegetation}

Beath (1943), Breckenridge and others (1974), Gough and others (1979), Lageson and others (1980), Ross and Hunter (1976), Wendell and others (1976), Young and Singleton (1977).

\subsection{Geology}

Averitt and Lopez (1972), Bass (1932), Bergantino (1977, 1980), Blackstone (1981), Breckenridge and others (1974), Brown (1952), Brown and others (1982), Bryson (1952), Bryson and Bass (1973), Cole and others 
(1980, 1982), Crist and Lowry (1972), Culler (1961), Culler and Peterson (1953), Denson and Horn (1975), Denson and others (1978), Denson and Keefer (1974), Dunlap (1958), Feltis (1981a, 1981b), Feltis and others (1981), Flores (1979), Flores and Canavello (1979), Gill and Cobban (1966), Glass (1976, 1980b, 1981, 1982), Grose (1972), Hausel and others (1979), Head and others (1979), Hodson and others (1973), Keefer (1974), Kent and others (1980), Kohout (1957), Lageson and others (1980), Lane and others (1972), Laudon and others (1976), Leopold and Miller (1954), Leopold and others (1964), Levings and others (1981), Lewis and Hotchkiss (1981), Lewis and Roberts (1978), Love and others $(1955,1977,1978 \mathrm{a}, 1978 \mathrm{~b}, 1978 \mathrm{c}, 1979$, 1980), Mapel (1958, 1959), Matson and Blumer (1973), McIntosh and Eister (1979), Morris (1956), Obernyer (1980), Parker and Andrews (1939), Peterson (1978, 1981), Pierce (1936), Pinchok (1975), Robinson and others (1964), Rocky Mountain Association of Geologists (1972), Sharp and others (1964), Stoner and Lewis (1980), Swenson and others (1976), Trimble (1980), Van Houten (1964), Warner (1947), Wendell and others (1976).

\subsection{ECONOMIC DEVELOPMENT}

Bass and others (1970), Bergantino and Cole (1981), Berryhill and others (1950), Breckenridge and others (1974), Calef (1960), City of Gillette/Campbell County Planning Commission (1978), Cole and others $(1980,1982)$, Combo and others (1949), Davis and Wood (1974), Davis (1976), Denson and Keefer (1974), Denson and others $(1973,1978)$, Dobson and Seelye (1982), Foss (1960), Freudenthal and others (1974), Glass $(1975,1976,1978,1980 \mathrm{a}, 1981,1982)$, Glass and others (1975), Goodier and others (1981), Grazis (1977a, 1977b, 1977c, 1977d), Greensdale (1980), Harza Engineering Company (1974), Hausel and others (1979), House and Cahill (1967), Hudson (1975), Jacobs and others (1982), Keefer and Schmidt (1973), Kilpatrick and Matchett (1982), Lageson and others (1980), Landers and others (1961), Lane and others (1972), Lowry and Cummings (1966), Mapel (1958, 1959), Matson and Blumer (1973), Matson and others (1968), Montana Coal Task Force (1973), Montana Department of Community Affairs, coordinator (1981), Montana State Engineer's Office (1948, 1961), National Research Council (1981), Northeast Wyoming Study Team (1978), Packer (1974), Pierce and others (1982), Pinchock (1975), Rahn $(1975,1976)$, Richards (1981), Sharp and others (1964), Shown
(1973), Smith (1981a, 1981b), Solley and others (1983), Strickland (1981), Struck (1975), Swanson and others (1976), Swanson and Huffman (1976), Unfer (1951), U.S. Bureau of Land Management $(1974,1978,1979,1980)$, U.S. Department of Commerce (1981), U.S. Geological Survey $(1973,1974$, 1979a, 1979b, 1979c, 1979d, 1980a, 1980b, 1982), Ver Ploeg (1982), Wendell and others (1976), Whitcomb and others (1966), Wyoming Department of Administration and Fiscal Control (1981), Wyoming Department of Economic Planning and Development (1981a, 1981b), Wyoming Office of the State Inspector of Mines (1982), Wyoming Water Planning Program (1972, 1973b).

\subsection{SURFACE-WATER DATA NETWORK}

Craig and Rankl 1978), Gilbert and Buchanan (1982), Knapton and Ferreira (1981), Omang and others (1979, 1982), Rankl and Barker (1977), Rucker and DeLong (1984), U.S. Geological Survey (1976a, 1976b, 1983a, 1983b).

\subsection{SURFACE-WATER QUANTITY}

Boner and others (1976), Craig and Rankl (1978), Culler (1961), Druse and others (1981), Ferreira (1981), Follansbee and Hodges (1925), Glover (1984), Johnson and Omang (1976), Lorens (1982), Lowham (1976), Lowry and Rankl (1984), Matthai (1979), Moore and Shields (1980), Omang and others $(1979,1982)$, Parrett and Omang (1981), Parrett and others (1978, 1984), Rankl (1982), Rankl and Barker (1977), Searcy (1959), Smith (1974), U.S. Geological Survey (1983a, 1983b), U.S. Office of Surface Mining (1981b), U.S. Water Resources Council (1981), Wyoming State Engineer's Office (1976).

\subsection{SURFACE-WATER QUALITY}

\subsection{Chemical Quality}

Briggs and Ficke (1978), Conner and others (1976), Druse and others (1981), Ebens and Shacklette (1982), Ehlke and others (1982), Frickel and Shown (1974), Geugh and others (1979), Greeson (1981a), Hem (1970), Hembree and others (1952), Karp and Botz (1975), Karp and others (1975), Knapton and Ferreira (1980), Knapton and McKinley (1977), Lorens (1982), Mackenthum (1973), McKee and Wolf (1971), Melancon and others (1979), National Academy of Sciences and National Academy of Engineering (1973), Ringen and others (1979), Rucker and DeLong (1984), U.S. Environmental Protection Agency (1976, 1977, 1979), U.S. Geo- 
logical Survey (1977, 1983a, 1983b), U.S. Public Health Service (1962).

\subsection{Suspended Sediment}

Hadley and Schumm (1961), Hembree and others (1952), Lagasse and others (1982), Langbein and Schumm (1958), Leopold and others (1964), Lidstone (1982), Long and Xiong (1981), Martinson (1982), Martinson and Meade (1983), Ringen and others (1979), Roach and Colby (1958), Rolfe and Hadley (1964), U.S. Bureau of Reclamation (1959), U.S. Geological Survey (1983a, 1983b).

\subsection{Biology}

Bahls (1979, 1980), Bahls and others (1981), Baril and others (1978), Baxter and Simon (1970), Gore and Johnson (1979), Greeson (1981a, 1981b, 1981c, 1981d, 1982), Klarich and Regele (1980), Klarich and others (1980), Knapton and Bochy (1976), Mallard (1981), McFeters and others (1974), Newell (1977), Rehwinkel (1978), Rockett (1976), U.S. Fish and Wildlife Service (1978, 1980), Wangsness (1977), Wangsness and Peterson (1980), Wesche and Johnson (1980), Wyoming Department of Environmental Quality (1982).

\subsection{Temperature}

Aagaard (1969), Lowham and others (1975), U.S. Geological Survey (1983a, 1983b).

\subsection{GROUND WATER}

\subsection{Ground-Water Data}

Ballance and Freudenthal (1975, 1976, 1977), Blankennagel and others (1977), Boner and others (1976), Botz and Bond (1966), Brown and others (1977, 1982), Busby and others (1983), Crist and Lowry (1972), Downey (1982a, 1982b), Gilbert and Buchanan (1982), Head and others (1979), Hodson (1971a, 1971b, 1974), Hodson and others (1973), Hopkins (1976), Kohout (1957), Larson and Daddow (1984), Lenfest (1984), Levings (1981a, 1981b, 1982a, 1982b, 1982c), Levings and others (1981), Lobmeyer (1980), Lobmeyer and others (1982), Lowry (1973), Lowry and Cummings (1966), Miller and others (1977), Perry (1931, 1932, 1935), Peterson (1981), Ragsdale (1982), Renick (1924), Riffenburg (1926), Ringen (1973, 1974), Slagle and Stimson (1979), Stevens (1978), Taylor (1965, 1968), Thayer (1983), U.S. Geological Survey (1975, 1979e, 1983a, 1983b), Wells (1982), Wells and others (1979), Whitcomb (1965), Whitcomb and Morris, (1964), Whitcomb and others (1966).

\subsection{Availability}

Anderson and Kelley (1976), Bergantino (1981), Crist and Lowry (1972), Downey (1982a), Feathers and others (1981), Ground-water Subgroup of Water Work Group, Northern Great Plains Resources Program (1974), Head and Merkel (1977), Hodson and others (1973), King (1974), LaRocque (1966), Levings and others (1981), Lewis and Hotchkiss (1981), Lewis and Roberts (1978), Littleton (1950), Lowry and Cummings (1966), Lowry and Rankl (1984), McCary and others (1983), Meinzer (1923), Miller (1976, 1979, 1981), Montana Bureau of Mines and Geology and U.S. Geological Survey (1978), Morris (1956), National Research Council (1981), Perry (1931, 1932, 1935), Rahn (1975, 1976), Renick (1929), Robinson and Foley (1941), Stoner and Lewis (1980), Taylor (1965, 1968, 1978), Warner (1947), Whitcomb (1965), Whitcomb and Morris (1964), Whitcomb and others (1966), Wyoming Water Planning Program (1972, 1973a).

8.3 Recharge and Movement

Blackstone (1981), Boner and others (1976), Downey (1982a), Feltis (1980a), Fitzwater (1981), Huntoon (1976), Konikow (1976), Levings (1982a, 1982b, 1982c, 1982d), Lobmeyer (1980), Meinzer (1923), Miller and Strausz (1980a, 1980b), Stone and Snoeberger (1977), Swenson and others (1976), U.S. Office of Surface Mining (1981a), Van Voast and others (1978), Wyoming State Engineer's Office (1976).

\subsection{Chemical Quality}

Beath (1943), Busby and others (1983), Crist and Lowry (1972), Dockins and others (1980), Ebens and Shaklette (1982), Everett (1979), Feder and others (1977), Feltis (1980b, 1980c, 1980d), Hem (1970), Hodson $(1971 \mathrm{~b}, 1974)$, Hodson and others (1973),Keefer (1974), Kohout (1957), Larson and Daddow (1984), Lee (1979, 1981), Littleton (1950), National Academy of Sciences and National Academy of Engineering (1973), Powers and others (1974), Renick (1924), Riffenburg (1926), Thorstenson and others (1979), U.S. Environmental Protection Agency (1976, 1977, 1979), U.S. Geological Survey (1977), U.S. Public Health Service (1962), Van Voast and Bremmer (1976), Van Voast and others (1978), Wells and others (1979).

\subsection{WATER-DATA SOURCES}

9.2 National Water Data Exchange (NAWDEX) Edwards (1980)

\subsection{SUPPLEMENTAL INFORMATION}

10.1 Hydrologic Studies by the Geological Survey Green (1983), Roberts (1983). 


\subsection{REFERENCES--Continued}

\subsection{Selected References}

Aagaard, F. C., 1969, Temperature of surface waters in Montana: Montana Fish and Game Department special publication, $613 \mathrm{p}$.

Anderson, K. E., and Kelly, J. E., 1976, Exploration for ground water in the Madison Limestone, Niobrara County, Wyoming, in Wyoming Geological Association Guidebook 28th Annual Field Conference: p. 277-281.

Averitt, Paul, and Lopez, Loreda, 1972, Bibliography and index of U.S. Geological Survey publications relating to coal, 1882-1970: U.S. Geological Survey Bulletin $1377,173 \mathrm{p}$.

Bahls, L. L., 1979, Benthic diatom diversity as a measure of water quality: Montana Acadamy of Science Proceedings, v. 38, p. 1-6.

1980 , Salinity and the structure of benthic algae (periphyton) communities in streams of the Southern Fort Union Region, Montana: Montana Department of Health and Environmental Sciences report, $35 \mathrm{p}$.

Bahls, L. L., Fillinger, Michael, Greene, Robert, Horpestad, Abraham, Ingman, Gary, and Weber, Erich, 1981, Biological water-quality monitoring, eastern Montana, 1979: Montana Department of Health and Environmental Sciences, Water Quality Bureau Report 81-3, $93 \mathrm{p}$.

Ballance, W. C., and Freudenthal, P. B., 1975, Ground-water levels in Wyoming, 1974: U.S. Geological Survey Open-File Report, 186 p. 1976, Ground-water levels in Wyoming, 1975: U.S. Geological Survey Open-File Report 76-598, 107 p.

1977, Ground-water levels in Wyoming, 1976: U.S. Geological Survey Open-File Report 77-686, $187 \mathrm{p}$.

Baril, S. F., Luedtke, R. J., and Roemhild, G. R., 1978, Environmental effects of western coal combustion, Part II-The aquatic macroin vertebrates of Rosebud Creek, Montana: U.S. Environmental Protection Agency report, EPA-600/3-78-099, 75 p.

Barrett, James, and others, 1980, Procedures recommended for overburden and hydrologic studies of surface mines, Thunder Basin project: U.S. Department of Agriculture, Forest Service, General Technical Report Int-71, $106 \mathrm{p}$.
Bass, N. W., 1932, The Ashland coal field; Rosebud, Powder River, and Custer Counties, Montana: U.S. Geological Survey Bulletin 831-B, p. 19-108.

Bass, N. W., Smith, H. L., and Horn, G. H., 1970, Standards for the classification of public coal lands: U.S. Geological Survey Circular 633, $10 \mathrm{p}$.

Baxter, G. T., and Simon, J. R., 1970, Wyoming fishes: Wyoming Game and Fish Department Bulletin No. 4, 168 p.

Beath, O. A., 1943, Toxic vegetation growing on the Salt Wash Sandstone Member of the Morrison Formation: American Journal of Botony, v. 30, p. 698-707.

Bergantino, R. N., 1977 [1980], Preliminary geologic map of the Miles City $1^{\circ}$ by $2^{\circ}$ quadrangle, Montana: Montana Bureau of Mines and Geology Open-File Report 49, 1 sheet.

1980 , Geologic map of the Ekalaka $1^{\circ}$ by $2^{\circ}$ quadrangle, southeastern Montana: Montana Bureau of Mines and Geology Montana Atlas 1-A, 1 sheet.

1981, Ground-water resources of the Ekalaka $1^{\circ}$ by $2^{\circ}$ quadrangle, southeastern Montana: Montana Bureau of Mines and Geology Montana Atlas 1-B, 1 sheet.

Bergantino, R. N., and Cole, G. A., 1981, Mineral resources map of the Ekalaka $1^{\circ}$ by $2^{\circ}$ quadrangle, southeastern Montana: Montana Bureau of Mines and Geology Montana Atlas 1-C, 1 sheet.

Berryhill, H. L., Jr., Brown, D. M., Brown, Andrew, and Taylor, D A., 1950, Coal resources of Wyoming: U.S. Geological Survey Circular 81, $78 \mathrm{p}$.

Blackstone, D. L., Jr., 1981, Structural uncoupling of the Madison aquifer, west margin, Powder River basin, Wyoming (abs): Tenth annual Rocky Mountain Ground Water Conference, Laramie, Wyo., 1981, Proceedings, p. 65.

Blankennagel, R. K., Miller, W. R., Brown, D. L., and Cushing, E. M., 1977, Report on preliminary data for Madison Limestone test well no. 1, NE1/4 SE1/4 sec. 15, T. 57 N., R. 65 W., Crook County, Wyoming: U.S. Geological Survey Open-File Report 77-164, $97 \mathrm{p}$.

Boner, F. C., Lowry, M. E., Lines, G. C., and Powell. 
J. E., 1976, Geohydrologic reconnaissance and measurement of perennial streams crossing outcrops of the Madison Limestone, northeastern Wyoming, 1974: U.S. Geological Survey Open-File Report 75-614, 63 p.

Botz, M. K., and Bond, E. W., 1966, Index and bibliography of ground-water studies in Montana: Montana Bureau of Mines and Geology Special Publication 37, 1 sheet.

Breckenridge, R. M., Glass, G. B., Root, F. K., and Wendell, W. G., 1974, Campbell County, Wyoming; geologic map atlas and summary of land, water, and mineral resources: The Geological Survey of Wyoming County Resources Series No. 3, 9 sheets.

Briggs, J. C., and Ficke, J. F., 1978, Quality of rivers in the United States, 1975 water yearbased on the National Stream Quality Accounting Network (NASQAN): U.S. Geological Survey Open-File Report 78-200, 436 p.

Brown, D. L., Blankennagel, R. K., Busby, J. F., and Lee, R. W., 1977, Preliminary data for Madison Limestone test well 2, SE1/4 SE $1 / 4$ sec. 18, T. 1 N., R. 54 E., Custer County, Montana: U.S. Geological Survey Open-File Report 77-863, $135 \mathrm{p}$.

Brown, D. L., Blankennagel, R. K., MacCary, L. M., and Peterson, J. A., 1982, Correlation of paleostructure and sediment deposition in the Madison Limestone and associated rocks in parts of Montana, North Dakota, South Dakota, Wyoming, and Nebraska: U.S. Geological Survey Open-File Report 82-906, $34 \mathrm{p}$.

Brown, R. W., 1952, Tertiary strata in eastern Montana and western North and South Dakota, in Billings Geological Society 3rd Annual Field Conference, Black Hills-Williston Basin, 1952, p. 89-92.

Bryson, R. P., 1952, The Coalwood coal field, Powder River County, Montana: U.S. Geological Survey Bulletin 973-B, p. 23-106.

Bryson, R. P., and Bass, N. W., 1973, Geology of Moorhead coal field, Powder River and Rosebud Counties, Montana: U.S. Geological Survey Bulletin 1338, 116 p.

Busby, J. F., Lee, R. W., and Hanshaw, B. B., 1983, Major geochemical processes related to the hydrology of the Madison aquifer system and associated rocks in parts of Montana, South Dakota, and Wyoming: U.S. Geological Survey Water-Resources Investigations Report 83-4093, 171 p., 17 over-size sheets.
Calef, W. C., 1960, Private grazing and public lands: Chicago, Ill., The University of Chicago Press, $292 \mathrm{p}$.

City of Gillette/Campbell County Planning Commission, and City of Gillette/Campbell County Department of Planning and Development, 1978, City of Gillette/Campbell County Comprehensive Planning Program 1978: Gillette, Wyo., $156 \mathrm{p}$.

Clark, P. F., Hodgson, H. E., and North, G. W., 1982, A guide to obtaining information from the USGS, 1982: U.S. Geological Survey Circular $777,42 \mathrm{p}$.

Cole, G. A., Matson, R. E., and Pederson, R. J., 1980, Montana coal: A guide to coal geology, resources and production: Montana Bureau of Mines and Geology Special Publication 83, $20 \mathrm{p}$.

Cole, G. A., Sholes, M. A., and Matson, R. E., 1982, Description of Montana coal fields and seam analyses: New York, McGraw-Hill, Keystone Coal Industry Manual, p. 580-585.

Combo, J. X., Brown, D. M., Pulver, H. F., and Taylor, D. A., 1949, Coal resources of Montana: U.S. Geological Survey Circular 53, 28 p.

Connor, J. J., Keith, J. R., and Anderson, B. M., 1976, Trace metal variations in soils and sagebrush in the Powder River basin, Wyoming and Montana: U.S. Geological Survey Journal of Research, v. 4, no. 1, pp. 49-59.

Cordell, G. V., Jr., 1960, Climate of the states, Montana: U.S. Department of Commerce, Weather Bureau, Climatography of the United States no. $60-24,21 \mathrm{p}$.

Craig, G. S., Jr., and Rankl, J. G., 1978, Analysis of runoff from small drainage basins in Wyoming: U.S. Geological Survey Water-Supply Paper 2056, $70 \mathrm{p}$.

Crist, M. A., and Lowry, M. E., 1972, Ground-water resources of Natrona County, Wyoming: U.S. Geological Survey Water-Supply Paper 1897, $92 \mathrm{p}$.

Culler, R. C., 1961, Hydrology of stock-water reservoirs in upper Cheyenne River basin, in Hydrology of the upper Cheyenne River basin: U.S. Geological Survey Water-Supply Paper 1531, Part A, p. 1-136.

Culler, R. C., and Peterson, H. V., 1953, Effect of stock reservoirs on runoff in the Cheyenne River basin above Angustura Dam: U.S. Geological Survey Circular 223, 33 p.

Davis, G. H., and Wood, L. A., 1974, Water demands for expanding energy development: 
U.S. Geological Survey Circular 703, 14 p. Davis, R. W., 1976, Hydrologic factors related to coal development in the eastern Powder River basin in Wyoming Geological Association Guidebook 28th Annual Field Conference: p. 203-207.

Davis, R. W., and Rechard, P. A., 1977, Effects of surface mining upon shallow aquifers in the eastern Powder River basin, Wyoming: University of Wyoming Water Resources Research Institute, Water Resources Series No. 67, 47 p.

Denson, N. M., Dover, J. H., and Osmonson, L. M., 1978, Structure contour and isopach maps of the Wyodak-Anderson coal bed in the Reno Junction-Antelope Creek area, Campbell and Converse Counties, Wyoming: U.S. Geological Survey Miscellaneous Field Studies Map MF-961, 1 sheet.

Denson, N. M., and Horn, G. H., 1975, Geologic and structure map of the southern part of the Powder River basin, Converse, Niobrara, and Natrona Counties, Wyoming: U.S. Geological Survey Miscellaneous Investigations Map I-877, 2 sheets.

Denson, N. M., and Keefer, W. R., 1974, Map of the Wyodak-Anderson coal bed in the Gillette area, Campbell County, Wyoming: U.S. Geological Survey Miscellaneous Investigations Map I-848-D.

Denson, N. M., Keefer, W. R., and Horn, G. H., 1973, Coal resources of the Gillette area, Wyoming: U.S. Geological Survey Miscellaneous Investigations Map I-848-C.

Deutsch, P. C., Ethridge, F. G., Franklin, W. T., Heil, R. D., McWhorter, D. B., and Ortiz, N. V., 1979, Overburden and hydrologic study of SEAM Thunder Basin study site, Campbell County, Wyoming: Colorado State University, Final Report, Volume II, SEAM Thunder Basin Study, $247 \mathrm{p}$.

Dobson, W. F., and Seelye, D. R., 1982, Mining technology assists oil recovery from Wyoming Field: Journal of Petroleum Technology, Feb. 1982, p. 259-265.

Dockins, W. S., Olson, G. J., McFeters, G. A., Turback, S. C., and Lee, R. W., 1980, Sulfate reduction in ground water of southeastern Montana: U.S. Geological Survey Water-Resources Investigations Report 80-9, $13 \mathrm{p}$.

Downey, J. S., 1982a, Geohydrology of the Madison and associated aquifers in parts of Montana, South Dakota, and Wyoming: U.S. Geological Survey Open-File Report 82-914, 108 p.
$1982 \mathrm{~b}$, Machine-readable data files from the Madison Limestone and Northern Great Plains regional aquifer system analysis projects, Montana, Nebraska, North Dakota, South Dakota, and Wyoming: U.S. Geological Survey WaterResources Investigations Report 82-4107, 26 p. Druse, S. A., Dodge, K. A., and Hotchkiss, W. R., 1981, Base flow and chemical quality of streams in the Northern Great Plains area, Montana and Wyoming: U.S. Geological Survey Water-Resources Investigations OpenFile Report 81-692, 60 p.

Dunlap, C. M., 1958, The Lewis, Fox Hills and Lance Formations of Upper Cretaceous age in the Powder River basin, Wyoming, in Wyoming Geological Association Guidebook 13th Annual Field Conference: p. 109-110.

Dunrud, C. R., and Osterwald, F. W., 1980, Effects of coal mine subsidence in the Sheridan, Wyoming, area: U.S. Geological Survey Professional Paper 1164, 49 p.

Ebens, R. J., and Shacklette, H. T., 1982, Geochemistry of some rocks, mine spoils, stream sediments, soils, plants, and waters in the Western energy region of the conterminous United States: U.S. Geological Survey Professional Paper 1237, 173 p.

Edwards, M. D., 1980, Directory of assistance centers of the National Water Data Exchange (NAWDEX): U.S. Geological Survey Open-File Report 80-1193, $10 \mathrm{p}$.

Ehlke, T. A., Runner, G. S., and Downs, S. C., 1982, Hydrology of Area 9, Eastern Coal Province, West Virginia: U.S. Geological Survey WaterResources Investigations Open-File Report 81-803, $63 \mathrm{p}$.

Everett, L. G., editor, 1979, Ground-water quality monitoring of western coal strip mining: U.S. Environmental Protection Agency report, $239 \mathrm{p}$.

Farnsworth, P. K., and Thompson, E. S., 1982, Mean monthly, seasonal, and annual pan evaporation for the United States: National Oceanic and Atmospheric Administration Report NWS 34, $82 \mathrm{p}$.

Feathers, K. R., Libra, Robert, and Stephenson, T. R., 1981, Occurrence and characteristics of ground water in the Powder River basin, Wyoming: University of Wyoming, Water Resources Research Institute report: v. I-1, 168 p., 4 append.; v. I-V, 8 pl.

Feder, G. L., Lee, R. W., Busby, J. F., and Saindon, L. G., 1977, Geochemistry of ground waters in 
the Powder River coal region, in U.S. Geological Survey, 1977, Geochemical Survey of the western energy regions, fourth annual progress report: U.S. Geological Survey OpenFile Report 77-872, p. 173-179

Feltis, R. D., 1980a, Map showing potentiometric surface of water in the Madison Group, Montana: Montana Bureau of Mines and Geology Hydro geologic Map 2, 1 sheet.

$1980 \mathrm{~b}$, Map showing dissolved-solids concentration of water in the Madison Group, Montana: Montana Bureau of Mines and Geology Hydro geologic Map 3, sheet 1.

$1980 \mathrm{c}$, Map showing ratio of sodium, potassium, and chloride to dissolved-solids concentration in water of the Madison Group, Montana: Montana Bureau of Mines and Geology Hydrogeologic Map 3, sheet 2.

$1980 \mathrm{~d}$, Map showing ratio of sulfate to total anions in water of the Madison Group, Montana: Montana Bureau of Mines and Geology Hydrogeologic Map 3, sheet 3.

1981a, Map showing configuration of the top of the Madison Group, Miles City 1-degree by 2-degree quadrangle, Montana: Montana Bureau of Mines and Geology Geologic Map 20, 1 sheet.

$1981 \mathrm{~b}$, Map showing configuration of the top of the Madison Group, Ekalaka 1-degree by 2-degree quadrangle, Montana: Montana Bureau of Mines and Geology Geologic Map 21, 1 sheet.

Feltis, R. D., Lewis, B. D., Frasure, R. L., Rioux, R. P., Jauhola, C. A., and Hotchkiss, W. R., 1981, Selected geologic data from the Northern Great Plains area of Montana: U.S. Geological Survey Water-Resources Investigations OpenFile Report 81-415, 61 p.

Ferreira, R. F., 1981, Mean annual streamflow of selected drainage basins in the coal area of southeastern Montana: U.S. Geological Survey Water-Resources Investigations Report 81-61, $21 \mathrm{p}$.

Fitzwater, P. L., 1981, Age and movement of ground water in the Madison Limestone, northeastern Wyoming: Tucson, Univ. of Arizona unpublished masters thesis, $83 \mathrm{p}$.

Flores, R. M., 1979, Restored stratigraphic cross sections and coal correlations in the Tongue River Member of the Fort Union Formation, Powder River area, Montana: U.S. Geological Survey Miscellaneous Field Studies Map MF-1127, 2 sheets.
Flores, R. M., and Canavello, D. A., 1979, Restored stratigraphic cross sections and coal correlations in the Tongue River Member of the Fort Union Formation, Powder River area, Wyoming: U.S. Geological Survey Miscellaneous Field Studies Map MF-1126, 2 sheets.

Follansbee, Rebert and Hodges, P. V., 1925, Some floods in the Rocky Mountain region: U.S. Geological Survey Water-Supply Paper 520-G, p. 105-129.

Foss, P. O., 1960, Politics and grass: Seattle, Wash., University of Washington Press, 236 p.

Freudenthal, D. D., Ricciardelli, Peter, and York, M. N., 1974, Coal development alternatives, an assessment of water use and alternatives: Wyoming Department of Economic Planning and Development report, 101 p., 7 appendixes with separate pagination.

Frickel, D. G., and Shown, L. M., 1974, Map showing streamflow volumes in northeastern Wyoming and southeastern Montana: U.S. Geological Survey Miscellaneous Investigations Map I-847-B, 1 sheet.

Gilbert, B. K., and Buchanan, T. J., 1982, Waterdata program of the U.S. Geological Survey: U.S. Geological Survey Circular 863, 16 p.

Gill, J. R., and Cobban, W. A., 1966, The Red Bird section of the Upper Cretaceous Pierre Shale in Wyoming: U.S. Geological Survey Professional Paper 393-A, 73 p.

Gillette Area Groundwater Monitoring Organization and Northeastern Wyoming Chapter, American Institute of Mining Engineers, 1982, Hydrology symposium on surface coal mines in Powder River basin, Gillette, Wyo., Nov. 3-5, 1982, Proceedings, 275 p.

Glass, G. B., 1975, Analyses and measured sections of 54 Wyoming coal samples (collected in 1974): Geological Survey of Wyoming Report of Investigations No. 11, 219 p.

1976, Update on the Powder River coal basin: Wyoming Geological Association Guidebook, 28th Annual Field Con ference, p. 209-220.

1978, Wyoming coal fields, 1978: Geological Survey of Wyoming Public Information Circular 9, $91 \mathrm{p}$.

1980 a, Wyoming coal production and summary of coal contracts: Geological Survey of Wyoming Public Information Circular 12, 99 p. editor, 1980b, Guidebook to the coal geology of the Powder River coal basin: Geological Survey of Wyoming Public Information Circular $14,188 \mathrm{p}$. 
1981, Index map to U.S. Geological Survey coal resource occurrence and coal development potential open-file reports in Wyoming: Geological Survey of Wyoming Map Series MS-9A, map, scale 1:1,000,000; accompanying text, $13 \mathrm{p}$.

1982, Description of Wyoming coal fields and seam analyses: Keystone Coal Industry Manual, New York, McGraw-Hill, p. 660-685; Geological Survey of Wyoming Reprint 43, $29 \mathrm{p}$.

Glass, G. B., Wendell, W. G., Root, F. K., and Breckenridge, R. M., compilers, 1975, Energy resources map of Wyoming: Geological Survey of Wyoming map, scale 1:500,000.

Glover, K. C., 1984, Storage analysis for ephemeral streams in semiarid regions: U.S. Geological Survey Water-Resources Investigations Report 83-4078, 55 p.

Goodier, J. T., and others, revised 1981, Wyoming mineral development monitoring system: Wyoming Department of Economic Planning and Development, Monitoring Report No. 405, variable pagination.

Gore, J. A., and Johnson, L. S., 1979, Observations on the initial biotic recolonization of a reclaimed channel of the Tongue River in Wyoming: University of Wyoming Water Resources Research Institute report, $55 \mathrm{p}$.

Gough, L. P., Shacklette, H. R., and Case, A. A., 1979, Element concentrations toxic to plants, animals, and man: U.S. Geological Survey Bulletin 1466, $80 \mathrm{p}$.

Grazis, S. L., 1977a, Geologic map and coal resources of the Pleasantdale quadrangle, Campbell County, Wyoming: U.S. Geological Survey Coal Investigations Map C-76, 3 sheets.

$1977 \mathrm{~b}$, Geologic map and coal resources of the Scaper Reservoir quadrangle, Campbell County, Wyoming: U.S. Geological Survey Coal Investigations Map C-77, 3 sheets.

1977c, Geologic map and coal resources of the Gap SW quadrangle, Campbell County, Wyoming: U.S. Geological Survey Coal Investigations Map C-78, 3 sheets.

1977d, Geologic map and coal resources of the Saddle Horse Butte quadrangle, Campbell County, Wyoming: U.S. Geological Survey Coal Investigations Map C-79, 3 sheets.

Green, S. L., compiler, 1983, Water-resources in vestigations of the U.S. Geological Survey in Wyoming, fiscal year 1983: U.S. Geological
Survey Open-File Report 83-770, 120 p.

Greensdale, W. M., 1980, Protecting alluvial valley floors-Congressional action defends their role in western agriculture: Engineering Bulletin, v. 52, August, p. 27-32.

Greeson, P. E., editor, 1981a, Biota and biological parameters as environmental indicators: U.S. Geological Survey Circular 848-B, 24 p. editor, $1981 \mathrm{~b}$, Organic substances in water: U.S. Geological Survey Circular 848-C, 19 p. 1981c, Infectious waterborne diseases: U.S. Geological Survey Circular 848-D, 19 p. editor, 1981d, Microbiology of the aquatic environment: U.S. Geological Survey Circular 848-E, 19 p.

editor, 1982, Biota and biological principles of the aquatic environment: U.S. Geological Survey Circular 848-A, 49 p.

Grose, T. L., 1972, Tectonics, in Geologic atlas of the Rocky Mountain region United States of America: Denver, Rocky Mountain Association of Geologists, p. 35-44.

Ground-water Subgroup of Water Work Group, Nor thern Great Plains Resource Program, 1974, Shallow ground water in selected areas in the Fort Union coal region: U.S. Geological Survey Open-File Report 74-371, 132 p.

Hadley, R. F., and Keefer, W. R., 1975, Map showing some potential effects of surface mining of the Wyodak-Anderson coal, Gillette area, Campbell County, Wyoming: U.S. Geological Survey Miscellaneous Investigations Map I-848-F.

Hadley, R. F., and Schumm, S. A., 1961, Sediment sources and drainage-basin characteristics in the upper Cheyenne River basin, in Hydrology of the upper Cheyenne River basin: U.S. Geological Survey Water-Supply Paper 1531, Part B, p. 137-198.

Hafen, L. R., and Hafen, A. W., editors, 1961, Powder River campaigns and Sawyer expedition of 1865: Glendale, Calif., The Arthur H. Clark Co., 386 p.

Hammond, E. H., 1964, Analysis of properties in land form geography: An application to broadscale land form mapping: Annals of the Association of American Geographers, v. 54, p. 11-19.

Harza Engineering Company, 1974, Powder River storage development: Wyoming State Engineer's Office, Wyoming Water Planning Program report, 5 sections with separate pagination. 
Hausel, W. D., and others, 1979, Wyoming mines and minerals: Geological Survey of Wyoming Map Series MS-5, scale 1:500,000.

Head, W. J., Kilty, K. T., and Knottek, R. K., 1979, Maps showing formation temperatures and configurations of the tops of the Minnelusa Formation and the Madison Limestone, Powder River basin, Wyoming, Montana, and adjacent areas: U.S. Geological Survey Miscellaneous Investigations Map I-1159.

Head, W. J., and Merkel, R. H., 1977, Hydrologic characteristics of the Madison Limestone, the Minnelusa Formation, and equivalent rocks as determined by well-logging formation evaluation, Wyoming, Montana, South Dakota, and North Dakota: U.S. Geological Survey Journal of Research, v. 5, no. 4, p. 473-485.

Hem, J. D., 1970, Study and interpretation of the chemical characteristics of natural water $(2 \mathrm{~d}$ ed.): U.S. Geological Survey Water-Supply Paper 1473, $363 \mathrm{p}$.

Hembree, C. H., Colby, B. R., Swenson, H. A., and Davis, J. R., 1952, Sedimentation and chemical quality of water in the Powder River drainage basin, Wyoming and Montana: U.S. Geological Survey Circular 170, 92 p.

Hodson, W. G., 1971a, Logs of wells in Campbell County, Wyoming: Wyoming State Engineer, Wyoming Water Planning Program Report No. $8,210 \mathrm{p}$.

$1971 \mathrm{~b}$, Chemical analyses of ground water in the Powder River Basin and adjacent areas, northeastern Wyoming: Wyoming Department of Economic Planning and Development report, $20 \mathrm{p}$.

1974, Records of water wells, springs, oiland gas-test holes, and chemical analyses of water for the Madison Limestone and equivalent rocks in the Powder River Basin and adjacent areas, northeastern Wyoming: Wyoming State Engineer report, $26 \mathrm{p}$.

Hodson, W. G., Pearl, R. H., and Druse, S. A., 1973 1974, Water resources of the Powder River Basin and adjacent areas, northeastern Wyoming: U.S. Geological Survey Hydrologic Investigations Atlas 465, 4 sheets.

Hopkins, W. B., 1976, Water-resources data for deep aquifers of eastern Montana: U.S. Geological Survey Water-Resources Investigations Report 76-40, 37 p.

House, V. W., and Cahill, T. E., 1967, Everybody's guide to Wyoming water administration: University of Wyoming Agricultural Extension
Service Bulletin 479, 31 p.

Hudson, H. H., 1975, Water for Wyoming's coal: Water Spectrum (U.S. Corps of Engineers), summer 1975, p. 41-46.

Huntoon, Peter, 1976, Permeability and ground water circulation in the Madison aquifer along the eastern flank of the Bighorn Mountains of Wyoming in Wyoming Geological Association Guidebook 28th Annual Field Conference: p. 283-290.

Imhoff, E. A., Fritz, T. O., and La Fevers, J. R., 1976, A guide to State programs for the reclamation of surface-mined areas: U.S. Geological Survey Circular 731, 33 p.

Jacobs, J. J., Bradley, E. B., and Vanvig, Andrew, 1982, Coal-energy development and agriculture in northeast Wyoming's Powder River basin: University of Wyoming Agricultural Experiment Station Report RJ-178, 77 p.

Johnson, M. V., and Omang, R. J., 1976, A method for estimating magnitude and frequency of floods in Montana: U.S. Geological Survey Open-File Report 75-650, 35 p.

Jordan, P. R., Bloyd, R. M., and Daddow, P. B., 1984, An assessment of cumulative impacts of coal mining on the hydrology in part of the Powder River structural basin, Wyoming-a progress report: U.S. Geological Survey WaterResources Investigations Report 83-4235, 25 p.

Karp, R. W., and Botz, M. K., 1975, Water quality inventory and management plan, middle Yellowstone River basin: Montana Department of Health and Environmental Sciences report, $109 \mathrm{p}$.

Karp, R. W., Klarich, D. A., and Botz, M. K., 1975, Water quality inventory and management plan, lower Yellowstone River basin: Montana Department of Health and Environmental Sciences report, $177 \mathrm{p}$.

Keefer, W. R., 1974, Regional topography, physiography,and geology of the Northern Great Plains: U.S. Geological Survey Open-File Report 74-50, 17 p.

1976, Role of earth sciences in Federal coal development in the West, in U.S. Geological Survey Annual Report, fiscal year 1976: p. 9-16.

Keefer, W. R., and Hadley, R. F., 1976, Land and natural resource information and some potential environmental effects of surface mining in the Gillette area, Wyoming: U.S. Geological Survey Circular 743, 27 p. 
Keefer, W. R., and Schmidt, P. W., 1973, Energy resources map of the Powder River basin, Wyoming and Montana: U.S. Geological Survey Miscellaneous Investigations Map I-847-A.

Kent, B. H., Berlage, L. J., and Boucher, E. M., 1980, Stratigraphic framework of coal beds underlying the western part of the Recluse $1^{\circ}$ $\times 12^{\circ}$ quadrangle, Campbell County, Wyoming: U.S. Geological Survey Coal Investigations Map C-81-C, 2 sheets.

Kilpatrick, F. A., and Matchett, D. L., editors, 1982, Water and energy-technical and policy issues: American Society of Civil Engineers, Eastern Conference, Pittsburg, Pa., May 24-26, 1982, and Western Conference, Fort Collins, Colo., June 28-30, 1982, proceedings, $651 \mathrm{p}$.

King, N. J., 1974, Maps showing occurrence of ground water in the Gillette area, Campbell County, Wyoming: U.S. Geological Survey Miscellaneous Investigations Map I-848-E.

Klarich, D. A., and Regele, S. M., 1980, Structure, general characteristics, and salinity relationships of benthic macroinvertebrate associations in streams draining the southern Fort Union coalfield region of southeastern Montana: Montana Department of Health and Environmental Sciences, Water Quality Bureau report, $148 \mathrm{p}$.

Klarich, D. A., Regele, S. M., and Bahls, L. L., 1980, Data report for the benthic macroinvertebrate and periphyton community inventory of streams draining the southern Fort Union coalfield region of southeastern Montana: Montana Department of Health and Environmental Sciences, Water Quality Bureau report, $268 \mathrm{p}$.

Knapton, J. R., and Bochy, B. M., 1976, Results of phytoplankton sampling at National Stream Quality Accounting Network stations in Montana-1975 water year: U.S. Geological Survey Open-File Report 76-219, 27 p.

Knapton, J. R., and Ferreira, R. F., 1980, Statistical analyses of surface-water-quality variables in the coal area of southeastern Montana: U.S. Geological Survey Water-Resources Investigations Report 80-40, 128 p.

Knapton, J. R., and McKinley, P. W., 1977, Water quality of selected streams in the coal area of southeastern Montana: U.S. Geological Survey Water-Resources Investigations Report 77-80, $145 \mathrm{p}$.
Kohout, F. A., 1957, Geology and ground-water resources of the Kaycee irrigation project, Johnson County, Wyoming, with a section on Chemical quality of the water by F.H. Rainwater: U.S. Geological Survey Water-Supply Paper 1360-E, p. 321-374.

Konikow, L. F., 1976, Preliminary digital model of ground-water flow in the Madison Group, Powder River basin and adjacent areas, Wyoming, Montana, South Dakota, North Dakota, and Nebraska: U.S. Geological Survey WaterResources Investigations Report 63-75, 44 p.

Lagasse, P. F., Li, Ruh-Ming, and Simons, D. B., 1982, Sediment control for the surface mining industry, in Kilpatrick, F. A., and Matchett, D. L., editors, Water and energy-technical and policy issues: American Society of Civil Engineers, Western Conference, Fort Collins, Colo., June 28-30, 1982, Proceedings, p. 519-524.

Lageson, D. R., and others, 1980, Natrona County, Wyoming: The Geological Survey of Wyoming County Resource Series No. 6, 8 sheets.

Landers, W. S., and others, 1961, Carbonizing properties of Wyoming coals: U.S. Bureau of Mines report RI 5731, $74 \mathrm{p}$.

Lane, D. W., in collaboration with Root, F. K., and Glass, G. B., 1972, Geologic map atlas and summary of economic mineral resources of Converse County, Wyoming: The Geological Survey of Wyoming County Resource Series No. 1, $22 \mathrm{p}$.

Langbein, W. B., and Iseri, K. T., 1960, General introduction and hydrologic definitions: U.S. Geological Survey Water-Supply Paper 1541-A, 29 p.

Langbein, W. B., and Schumm, S. A., 1958, Yield of sediment in relation to mean annual precipitation: American Geophysical Union Trans actions, v. 39 , no. 6, p. 1076-1084.

Larson, L. R., and Daddow, R. L., 1984, Groundwater quality data from the Powder River Basin, northeastern Wyoming: U.S. Geological Survey Open-File Report 83-939 (in press).

LaRocque, G. A., Jr., 1966, General availability of ground water and depth to water level in the Missouri River basin: U.S. Geological Survey Hydrologic Investigations Atlas 217, 1 sheet.

Laudon, R. B., Curry, W. H. III, and Runge, J. S., editors, 1976, Geology and energy resources of the Powder River basin: Wyoming Geological Association Guidebook 28th Annual Field Conference, $328 \mathrm{p}$. 
Lee, R. W., 1979, Ground-water-quality data from the northern Powder River basin, southeastern Montana: U.S. Geological Survey WaterResources Investigations Open-File Report 79-1331, 55 p.

1981, Geochemistry of water in the Fort Union Formation of the northern Powder River Basin, southeastern Montana: U.S. Geological Survey Water-Supply Paper 2076, 17 p. (1982).

Lenfest, L. W., Jr., 1984, Evapotranspiration rates at selected sites in the Powder River basin, Wyoming and Montana: U.S. Geological Survey Water-Resources Investigations Report 82-4105 (in press).

Leopold, L. B., and Miller, J. P., 1954, A postglacial chronology for some alluvial valleys in Wyoming: U.S. Geological Survey Water-Supply Paper 1261, 90 p.

Leopold, L. B., Wolman, M. G., and Miller, J. P., 1964, Fluvial processes in geomorphology: San Francisco, W. H. Freeman and Company, 522 p.

Leopold, L. B., and others, 1971, A procedure for evaluating environmental impact: U.S. Geological Survey Circular 645, 13 p.

Levings, G. W., 1981a, Selected drill-stem-test data from the Northern Great Plains area of Montana: U.S. Geological Survey Water-Resources Investigations Open-File Report 81-326, 20 p. 1982a, Potentiometric-surface map of water in the Judith River Formation and equivalent units in the northern Great Plains area of Montana: U.S. Geological Survey Open-File Report 82-562, 1 sheet.

1982b, Potentiometric-surface map of water in the Lakota Formation and equivalent units in the northern Great Plains area of Montana: U.S. Geological Survey Open-File Report 82-563, 1 sheet.

1982c, Potentiometric-surface map of water in the Fox Hills-lower Hell Creek aquifer in the northern Great Plains area of Montana: U.S. Geological Survey Open-File Report 82-564, 1 sheet.

1982d, Potentiometric-surface map of water in the Eagle Sandstone and equivalent units in the northern Great Plains area of Montana: U.S. Geological Survey Open-File Report 82-565, 1 sheet.

Levings, J. F., Levings, G. W., Feltis, R. D., Hotchkiss, W. R., and Lee, R. W., 1981, Selective annotated bibliography of geology and groundwater resources for the Montana part of the
Northern Great Plains Regional AquiferSystem Analysis: U.S. Geological Survey Water-Resources Investigations Open-File Report 81-401, 91 p.

Lewis, B. D., and Hotchkiss, W. R., 1981, Thickness, percent sand, and configuration of shallow hydrogeologic units in the Powder River Basin, Montana and Wyoming: U.S. Geological Survey Miscellaneous Investigations Map I-1317, 6 sheets.

Lewis, B. D., and Roberts, R. S., 1978, Geology and water-yielding charac teristics of rocks of the northern Powder River basin, southeastern Montana: U.S. Geological Survey Miscellaneous Investigations Map I-847-D, 2 sheets.

Lidstone, C. D., 1982, Stream channel reconstruction and drainage basin stability, in Hydrology symposium on surface coal mines in Powder River basin, Gillette, Wyo., Nov. 3-5, 1982: Gillette Area Ground-water Monitoring Organization and Northeast Wyoming Chapter, American Institute of Mining Engineers, Proceedings, p. 43-56.

Littleton, R. T., 1950, Ground-water conditions in the vicinity of Gillette, Wyoming, with a section on The quality of ground waters, by $\mathrm{H}$. A. Swenson: U.S. Geological Survey Circular 76, $43 \mathrm{p}$.

Lobmeyer, D. H., 1980, Preliminary potentiometric-surface map showing freshwater heads for the lower Cretaceous rocks in the Northern Great Plains of Montana, North Dakota, South Dakota, and Wyoming: U.S. Geological Survey Open-File Report 80-757.

Lobmeyer, D. H., Anna, L. O., and Busby, J. F., 1982, Preliminary data for Northern Great Plains test well 1, NW1/4 NE1/4 sec. 11, T. 55 N.; R. 77 W., Sheridan County, Wyoming: U.S. Geological Survey Open-File Report 82-446, $72 \mathrm{p}$.

Lohman, S. W., and others, 1972, Definitions of selected ground-water terms-revisions and conceptual refinements: U.S. Geological Survey Water-Supply Paper 1988, 21 p.

Long, Y. Q., and Xiong, G. S., 1981, Sediment measurement in the Yellow River; Erosion and sediment transport measure ment: Proceedings of the Florence Symposium, June 1981, International Association of Hydrologic Sciences Publication no. 133, p. 275-285.

Lorens, J. A., 1982, Computer programs for model- 
ing flow and water quality of surface water systems: U.S. Geological Survey Open-File Report 82-430, $62 \mathrm{p}$.

Love, J. D., Weitz, J. L., and Hose, R. K., 1955, Geologic map of Wyoming: U.S. Geological Survey map, scale 1:500,000.

Love, J. D., and others, 1977, Geologic map of the Newcastle $1^{\circ}$ by $2^{\circ}$ quadrangle northeastern Wyoming and western South Dakota: U.S. Geological Survey Miscellaneous Field Studies Map MF-883.

1978a, Preliminary geologic map of the Armino $1^{\circ}$ by $2^{\circ}$ quadrangle, central Wyoming: U.S. Geological Survey Open-File Report 78-1089, $10 \mathrm{p}$.

1978b, Preliminary geologic map of the Sheridan $1^{\circ}$ by $2^{\circ}$ quadrangle, northern Wyoming: U.S. Geological Survey Open-File Report 78-456, $6 \mathrm{p}$.

1978c, Preliminary geologic map of the Gillette $1^{\circ}$ by $2^{\circ}$ quadrangle, northeastern Wyoming and western South Dakota: U.S. Geological Survey Open-File Report 78-343, 8 p.

1979, Preliminary geologic map of the Casper

$1^{\circ}$ by $2^{\circ}$ quadrangle, central Wyoming: U.S. Geological Survey Open-File Report 79-961, $14 \mathrm{p}$.

1980, Geologic map of the Torrington $1^{\circ}$ by $2^{\circ}$ quadrangle, southeastern Wyoming and western Nebraska: U.S. Geological Survey miscellaneous Field Studies Map MF-1184.

Lowers, A. R., 1960, Climate of the states, Wyoming: U.S. Department of Commerce, Weather Bureau, Climatography of the United States, no. $60-48,16 \mathrm{p}$.

Lowham, H. W., 1976, Techniques for estimating flow characteristics of Wyoming streams: U.S. Geological Survey Water-Resources Investigations Report 76-112, 83 p.

Lowham, H. W., Kircher, J. E., and Boner, F. C., 1975, Temperatures of Wyoming streams: Wyoming State Engineer, Wyoming Water Planning Program Report No. 15, 115 p.

Lowry, M. E., 1973, Hydrology of the uppermost Cretaceous and lowermost Paleocene rocks in the Hilight oil field, Campbell County, Wyoming: U.S. Geological Survey Open-File Report, 60 p.

Lowry, M. E., and Cummings, T. R., 1966, Groundwater resources of Sheridan County, Wyoming: U.S. Geological Survey Water-Supply Paper 1807, 77 p.
Lowry, M. E., and Rankl, J. G., 1984, Hydrology of the Whitetail Butte area, northern Campbell County, Wyoming: U.S. Geological Survey Water-Resources Investigations Report 82-4117 (in press).

Lusby, G. C., and Toy, T. J., 1976, An evaluation of surface-mine spoils area restoration in Wyoming using rainfall simulation: Earth Surface Processes, v. 1, p. 375-386.

MacCary, L. M., 1981, Apparent water resistivity, porosity, and ground-water temperature of the Madison Limestone and underlying rocks in parts of Montana, Nebraska, North Dakota, South Dakota, and Wyoming: U.S. Geological Survey Open-File Report 81-629, 43 p., 21 over-size sheets.

MacCary, L. M., Cushing, E. M., and Brown, D. L., 1983, Potentially favorable areas for largeyield wells in the Red River Formation and Madison Limestone in parts of Montana, North Dakota, South Dakota, and Wyoming: U.S. Geological Survey Professional Paper 1273-E, $13 \mathrm{p}$.

Mackenthum, K. M., 1973, Toward a cleaner aquatic environment: U.S. Environmental Protection Agency, Washington, D.C.

Mallard, G. E., 1981, Micro-organisms in stormwater, in Greeson, P.E., editor, Microbiology of the aquatic environment: U.S. Geological Survey Circular 848-E, p. E23-E33.

Mapel, W. J., 1958, Coal in the Powder River basin in Wyoming Geological Association Guidebook 13th Annual Field Conference: p. 218-224. 1959, Geology and coal resources of the Buffalo Lake-De Smet area, Johnson and Sheridan Counties, Wyoming: U.S. Geological Survey Bulletin 1078, 148 p.

Martinson, H. A., 1982, Channel changes on Powder River between Moorhead and Broadus, Montana, 1939-1978: Fort Collins, Colo., Colorado State University unpublished thesis, $83 \mathrm{p}$.

Martinson, H. A., and Meade, R. H., 1983, Channel changes of Powder River, 1938-78, Powder River County, Montana: U.S. Geological Survey Hydrologic Investigations Atlas HA-661, 3 sheets.

Matson, R. E., and Blumer, J. W., 1973, Quality and reserves of strippable coal, selected deposits, southeastern Montana: Montana Bureau of Mines and Geology Bulletin 91, $135 \mathrm{p}$.

Matson, R. E., Dahl, G. G., Jr., and Blumer, J. W., 
1968, Strippable coal deposits on state land, Powder River County, Montana: Montana Bureau of Mines and Geology Bulletin 69, $81 \mathrm{p}$.

Matthai, H. F., 1979, Hydrologic and human aspects of the 1976-77 drought: U.S. Geological Survey Professional Paper 1130, 84 p.

McFeters, G. A., Bissonnette, G. K., Jezeski, J. J., Thomson, C. A., and Stuart, D. G., 1974, Comparative survival of indicator bacteria and enteric pathogens in well water: Applied Microbiology, v. 27, p. 823-829.

McIntosh, W. L., and Eister, M. F., 1979, Geologic map index of Wyoming: U.S. Geological Survey maps, 13 unnumbered sheets.

McKee, J. E., and Wolf, H. W., 1971, Water quality criteria [2d ed]: California State Water Quality Control Board Pub. 3-A, 548 p.

Meinzer, O. E., 1923, Outline of ground-water hydrology: U.S. Geological Survey WaterSupply Paper 494, 71 p.

Melancon, S. M., Hess, B. C., and Thomas, R. W., 1979, Assessment of energy resource development impact on water quality: the Tongue and Powder River basins: U.S. Environmental Protection Agency, Office of Research and Development Report, EPA-600/7-79-249, $197 \mathrm{p}$.

Miller, J. F., Frederick, R. H., and Tracey, R. J., 1973a, Precipitation-frequency atlas of the western United States; Montana: National Oceanic and Atmospheric Administration, National Weather Service Atlas, v.I, 41 p.

$1973 \mathrm{~b}$, Precipitation-frequency atlas of the western United States; Wyoming: National Oceanic and Atmospheric Administration, $\mathrm{Na}$ tional Weather Service atlas, v. II, $43 \mathrm{p}$.

Miller, M. R., Bermel, W. M., Bergantino, R. N., Sonderegger, J. L., Norbeck, P. M., and Schmidt, F. A., 1977, Compilation of hydrogeologic data for southeastern Montana (in map form): Montana Bureau of Mines and Geology Open-File Report 26, 7 p.

Miller, W. R., 1976, Water in carbonate rocks of the Madison Group in southeastern Montana-a preliminary evaluation: U.S. Geological Survey Water-Supply Paper 2043, $51 \mathrm{p}$.

1979, Water resources of the central Powder River area of south eastern Montana: Montana Bureau of Mines and Geology Bulletin 108, $65 \mathrm{p}$.

1981, Water resources of the southern Powder River area, southeastern Montana: Montana
Bureau of Mines and Geology Memoir 47,53 p. Miller, W. R., and Strausz, S. A., 1980a, Preliminary map showing freshwater heads for the Mission Canyon and Lodgepole Limestones and equivalent rocks of Mississippian age in the Northern Great Plains of Montana, North and South Dakota, and Wyoming: U.S. Geological Survey Water-Resources Investigations Open-File Map 80-729, 1 sheet.

1980b, Preliminary map showing freshwater heads for the Red River Formation, Bighorn Dolomite, and equivalent rocks of Ordovician age in the Northern Great Plains of Montana, North and South Dakota, and Wyoming: U.S. Geological Survey Water-Resources Investigations Open-File Map 80-730, 1 sheet.

Montagne, Clifford, Munn, L. C., Nielsen, G. A., Rogers, J. W., and Hunter, H. E., 1982, Soils of Montana: University of Montana, Montana Agriculture Experiment Station Bulletin 744, $95 \mathrm{p}$.

Montana Bureau of Mines and Geology and U.S. Geological Survey, 1978, Ground water of the Fort Union Coal Region, eastern Montana: Montana Bureau of Mines and Geology Special Publication 80, $47 \mathrm{p}$.

Montana Coal Task Force, 1973, Coal development in eastern Montana: Montana Department of Natural Resources and Conservation, $80 \mathrm{p}$.

Montana Department of Community Affairs, coordinator, 1981, Existing land use, Rosebud, Big Horn, Powder River, Treasure, Custer, and Garfield Counties, Montana, as part of Montana Statewide Cooperative Land Use Program: Individual maps.

Montana State Engineer's Office, 1948, Water resources survey, Custer County, Montana, Part I, History of land and water use on irrigated areas, and Part II, Maps showing irrigated areas in colors designating the sources of supply: Montana State Engineer report, $78 \mathrm{p}$. 1961, Water resources survey, Powder River County, Montana, Part I, History of land and water use on irrigated areas, and Part II, Maps showing irrigated areas in colors designating the sources of supply: Montana State Engineer report, $38 \mathrm{p}$.

Moore, L. G., and Shields, R. R., 1980, Streamflow characteristics of the Yellowstone River basin, Montana through 1976: U.S. Geological Survey Water-Resources Investigations Report 80-41, $67 \mathrm{p}$.

Morris, D. A., 1956, Reconnaissance of the geology 
and ground-water resources in the Cheyenne River drainage basin in northern Converse County, Wyoming: U.S. Geological Survey Open-File Report, 14 p.

Narten, P. F., Litner, S. F., Allingham, J. W., Foster, Lee, Larsen, D. M., and McWreath, H. C., III, 1983, Reclamation of mined lands in the western coal region: U.S. Geological Survey Circular 872, 56 p.

National Academy of Sciences, 1974, Rehabilitation potential of western coal lands: Cambridge, Mass., Ballinger Publishing Co., 198 p.

National Academy of Sciences and National Academy of Engineering, 1973 [1974], Water quality criteria, 1972: U.S. Government Printing Office, 594 p.

National Oceanic and Atmospheric Administration, 1973, Monthly normals of temperature, precipitation, and heating and cooling degree days 1941-70: U.S. Department of Commerce Publication, Climatography of the U.S. No. 81, 8 p.

National Research Council, Committee on GroundWater Resources in Relation to Coal Mining, 1981, Coal mining and ground-water resources in the United States: Washington, National Academy Press, $197 \mathrm{p}$.

Newell, R. L., 1977, Aquatic invertebrates of the Yellowstone River Basin, Montana: Montana Department of Natural Resources and Conservation, Yellowstone Impact Study Technical Report No. 5, 109 p.

Northeast Wyoming Study Team, 1978, Report on the Yellowstone basin and adjacent coal area, northeast Wyoming: Missouri River Basin Commission Level B study, v. 8, 10 chapters.

Obernyer, S. L., 1980, The Lake De Smet coal seam: the product of active basin-margin sedimentation and tectonics in the Lake De Smet area, Johnson County, Wyoming, during Eocene Wasatch time, in Guidebook to the coal geology of the Powder River Coal Basin, Wyoming: Geological Survey of Wyoming Public Information Circular No. 14, p. 31-70.

Omang, R. J., Hull, J. A., and Parrett, Charles, 1979, Annual peak discharges from small drainage areas in Montana for stations discontinued before 1978: U.S. Geological Survey Open-File Report 79-510, 117 p.

Omang, R. J., Parrett, Charles, and Hull, J. A., 1982, Annual peak discharges from small drainage areas in Montana through September 1981:U.S. Geological Survey Open-File Report
82-270, 114 p.

Packer, P. E., 1974, Rehabilitation potential and limitations of surface-mined land in the Northern Great Plains: U.S. Department of Agriculture, Forest Service, General Technical Report INT-14, $44 \mathrm{p}$.

Parker, F. S., and Andrews, D. A., 1939, The Mizpah coal field, Custer County, Montana: U.S. Geological Survey Bulletin 906-C, p. 85-133.

Parrett, Charles, Carlson, D. D., Craig, G. S., Jr., and Chin, E. H., 1984, Floods of May 1978 in southeastern Montana and northeastern Wyoming: U.S. Geological Survey Professional Paper 1244 (in press).

Parrett, Charles, Carlson, D. D., Craig, G. S., Jr., and Hull, J. A., 1978, Data for floods of May 1978 in northeastern Wyoming and southeastern Montana: U.S. Geological Survey Open-File Report 78-985, 16 p.

Parrett, Charles, and Omang, R. J., 1981, Revised techniques for estimating magnitude and frequency of floods in Montana: U.S. Geological Survey Open-File Report 81-917, 70 p.

Perry, E. S., 1931, Ground water in eastern and central Montana: Montana Bureau of Mines and Geology Memoir 2, $59 \mathrm{p}$.

1932, Shallow wells near Terry, Montana, as a source of irrigation water: Montana Bureau of Mines and Geology Miscellaneous Contribution $3,7 \mathrm{p}$.

1935, Geology and ground-water resources of southeastern Montana: Montana Bureau of Mines and Geology Memoir 14, 67 p.

Peterson, J. A., 1978, Subsurface geology and porosity distribution, Madison Limestone and underlying formations, Powder River Basin, northeastern Wyoming and southeastern Montana, and adjacent areas: U.S. Geological Survey Open-File Report 78-783, 9 p.

1981 , Stratigraphy and sedimentary facies of the Madison Limestone and associated rocks in parts of Montana, North Dakota, South Dakota, Wyoming, and Nebraska: U.S. Geological Survey Open-File Report 81-642, 92 p., 21 over-size sheets.

Pierce, F. W., Kent, B. H., and Grundy, W. D., 1982, Geostatistical analysis of a 113-billionton coal deposit, central part of the Powder River basin, northeastern Wyoming, in Gurgel, K. D., editor, Proceedings, Fifth Symposium on the Geology of Rocky Mountain Coal: Utah Geological and Mineral Survey Bulletin 118, p. 262-272. 
Pierce, W. G., 1936, The Rosebud coal field, Rosebud and Custer Counties, Montana: U.S. Geological Survey Bulletin 847-B, p. 43-120.

Pinchock, J. M., 1975, Index map and bibliography of coal studies in Montana: Montana Bureau of Mines and Geology Special Publication 71, 1 sheet.

Powers, J. F., Bond, J. J., Sandoval, F. M., and Wilis, W. D., 1974, Nitrification in Paleocene shale: Science, v. 183, March 1974, p. 1077-1078.

Ragsdale, J. O., 1982, Ground-water levels in Wyoming, 1971 through part of 1980: U.S. Geological Survey Open-File Report 82-859, $200 \mathrm{p}$.

Rahn, P. H., 1975, Ground water in coal strip-mine spoils, Powder River basin: Montana Academy of Sciences, Proceedings of Fort Union Coal Field Symposium, v. 3, Reclamation Section, p. 348-361.

1976, Potential of coal strip-mine spoils as aquifers in the Powder River basin: Old West Regional Commission, project no. 10470025, Billings, Mont., 108 p.

Rankl, J. G., 1982, An empirical method for determining average soil infiltration rates and runoff, Powder River structural basin, Wyoming: U.S. Geological Survey Water-Resources Investigations Report 81-76, $38 \mathrm{p}$.

Rankl, J. G., and Barker, D. S., 1977, Rainfall and runoff data from small basins in Wyoming: Wyoming State Engineer, Wyoming Water Planning Program Report no. 17, 195 p.

Raynolds, W. F., 1868, Report on the exploration of the Yellowstone River: Washington, D.C., The Secretary of War, $174 \mathrm{p}$.

Rechard, P. A., and Larson, L. W., 1982, Hydrology, coal development, and the Missouri Basin, in Kilpatrick, F. A., and Matchett, D. L., editors, Water and energy-technical and policy issues: American Society of Civil Engineers, Western Conference, Fort Collins, Colo., June 28-30, 1982, Proceedings, p. 432-437.

Rehwinkel, B. J., 1978, Powder River aquatic ecology project final report: Montana Department of Fish and Game report, 119 p.

Renick, B. C., 1924, Base exchange in ground water by silicates as illustrated in Montana: U.S. Geological Survey Water-Supply Paper 520-D, p. 53-72.

1929, Geology and ground-water resources of central and southern Rosebud County, Montana, with chemical analyses of the waters by
H. G. Riffenburg: U.S. Geological Survey Water-Supply Paper 600, 140 p.

Rhodes, F. H. T., and Stone, R. O., editors, 1981, Language of the earth: New York, Pergamon Press, 415 p.

Richards, Bill, 1981, Powder River basin-new energy frontier: National Geographic, Special Report on Energy, Feb. 1981, p. 86-113.

Riffenburg, H. B., 1926, Chemical character of ground water of the northern Great Plains: U.S. Geological Survey Water-Supply Paper 560-B, p. 31-52.

Ringen, B. H., 1973, Records of ground-water levels in Wyoming, 1940-1971: Wyoming State Engineer, Wyoming Water Planning Program Report No. 13, 479 p.

1974, Ground-water levels in Wyoming, 1972-1973: Wyoming State Engineer, Wyoming Water Planning Program Report No. 13, supplement no. 1, 158 p.

Ringen, B. H., Shown, L. M., Hadley, R. F., and Hinkley, T. K., 1979, Effect on sediment yield and water quality of a nonrehabilitated surface mine in north-central Wyoming: U.S. Geological Survey Water-Resources Investigations Report 79-47, 23 p.

Roach, C. H., and Colby, B. R., 1958, Erosion and deposition of sediment in stock reservoirs in the Powder River drainage basin, Wyoming: U.S. Geological Survey Open-File Report, 55 p.

Roberts, R. S., compiler, 1983, Water-resources investigations of the U.S. Geological Survey in Montana, October 1982 through September 1983: U.S. Geological Survey Open-File Report 83-260, 44 p.

Robinson, C. S., Mapel, W. J., and Bergendahl, M. H., 1964, Stratigraphy and structure of the northern and western flanks of the Black Hills uplift, Wyoming, Montana, and South Dakota: U.S. Geological Survey Professional Paper 404, $134 \mathrm{p}$.

Robinson, T. W., and Foley, F. C., 1941, Memorandum regarding the artesian well near Osage, Wyoming (Jones No. 1 Well): U.S. Geological Survey Open-File Report, 9 p.

Rockett, L. C., 1976, The limnology of existing strip mine ponds in northeastern Wyoming as related to mined land reclamation: Wyoming Game and Fish Department Completion Report, 28 p.

Rocky Mountain Association of Geologists, 1972, Geologic atlas of the Rocky Mountain Region, United States of America: Denver, Colo., Rocky 
Mountain Association of Geologists, 331 p.

Rolfe, B. N., and Hadley, R. F., 1964, Weathering and transport of sediment in the Cheyenne River Basin, eastern Wyoming, in Proceedings of the 12th National Conference on Clays and Clay Minerals, Atlanta, Ga., September/October 1963: New York, Pergamon Press, p. 649-670.

Ross, R. L., and Hunter, H. E., 1976, Climax vegetation of Montana: U.S. Department of Agriculture, Soil Conservation Service report, $64 \mathrm{p}$.

Rucker, S. J., IV., and DeLong, L. L., 1984, Evaluation of selected surface-water-quality stations in Wyoming: U.S. Geological Survey WaterResources Investigations Report 82-4003 (in press).

Schumm, S. A., and Hadley, R. F., 1957, Arroyos and the semiarid cycle of erosion: American Journal of Science, v. 255, March 1957, p. 161-174.

Searcy, J. K., 1959, Flow-duration curves: U.S. Geological Survey Water-Supply Paper 1542-A, $33 \mathrm{p}$.

Sharp, W. M., McKay, E. J., McKeown, F. A., and White, A. M., 1964, Geology and uranium deposits of the Pumpkin Buttes area of the Powder River basin, Wyoming: U.S. Geological Survey Bulletin 1107-H, p. 541-638.

Shown, L. M., 1973, Land use map of the Gillette area, Wyoming, 1970: U.S. Geological Survey Miscellaneous Investigations Map I-848-A.

Simonson, G. H., and others, compilers, 1978, General soil map Montana: U.S. Department of Agriculture, Soil Conservation Service, issued by Montana State University, Bozeman Extension, Miscellaneous publication no. 16, map.

Slagle, S. E., and others, 1983, Hydrology of Area 49, Northern Great Plains and Rocky Mountain coal provinces, Montana and Wyoming: U.S. Geological Survey Water-Resources Investigations Open-File Report 82-682, 94 p.

Slagle, S. E., and Stimson, J. R., 1979, Hydrogeologic data from the northern Powder River basin, southeastern Montana: U.S. Geological Survey Water-Resources Investigations Open-File Report 79-1332, 111 p.

Smith, J. F., 1981a, Permit requirements for development of energy and other selected natural resources for the State of Wyoming: U.S. Geological Survey Open-File Report 81-1287, 60 p. 1981b, Permit requirements for energy and other natural resources for the State of Montana: U.S. Geological Survey Open-File Report 81-1267, 76 p.

Smith, V. E., 1974, Characteristics of Wyoming stock-water ponds and dike spreader systems: University of Wyoming, Water Resources Research Institute, Water Resources Series No. 47, $47 \mathrm{p}$.

Solley, W. B., Chase, E. B., and Mann, W. B., IV., 1983, Estimated use of water in the United States in 1980: U.S. Geological Survey Circular 1001, $56 \mathrm{p}$.

Steele, T. D., and Hillier, D. E., compilers and editors, 1981, Assessment of impacts of proposed coal-resource and related economic development on water resources, Yampa River basin, Colorado and Wyoming-a summary: U.S. Geological Survey Circular 839, 56 p.

Stephens, J. R., Jr., 1975, Soil survey of Johnson County, Wyoming, southern part: U.S. Department of Agriculture, Soil Conservation Service, $156 \mathrm{p}$.

Stevens, M. D., 1978, Ground-water levels in Wyoming, 1977: U.S. Geological Survey OpenFile Report 78-605, 203 p.

Stone, Randolph, and Snoeberger, D. F., 1977, Cleat orientation and areal hydraulic anisotropy of a Wyoming coal aquifer: Ground Water, v. 15 , no. 6 , p. 434-438.

Stoner, J. D., and Lewis, B. D., 1980, Hydrogeology of the Fort Union coal region, eastern Montana: U.S. Geological Survey Miscellaneous Investigations Map I-1236, 2 sheets.

Strickland, Dale, 1981, Annual report of big game harvest 1980: Wyoming Game and Fish Department report, $161 \mathrm{p}$.

Struck, D. G., 1975, Conflictive land use: Coal strip mining and agriculture: Western Interstate Commission of Higher Education report, 1 sheet.

Swanson, V. E., and Huffman, Claude, Jr., 1976, Guidelines for sample collecting and analytical methods used in the U.S. Geological Survey for determining the chemical composition of coal: U.S. Geological Survey Circular 735, 11 p.

Swanson V. E., and others, 1976, Collection, chemical analysis and evaluation of coal samples in 1975: U.S. Geological Survey OpenFile Report 76-468, 503 p.

Swenson, F. A., Miller, W. R., Hodson, W. G., and Visher, F. N., 1976, Maps showing configuration and thickness and potentiometric surface 
and water quality in the Madison Group, Powder River basin, Wyoming and Montana: U.S. Geological Survey Miscellaneous Investigations Map I-847-C, 2 sheets.

Taylor, O. J., 1965, Ground-water resources along the Cedar Creek anticline in eastern Montana: Montana Bureau of Mines and Geology Memoir 40, 44 p.

1968, Ground-water resources of the northern

Powder River valley, southeastern Montana: Montana Bureau of Mines and Geology Bulletin 66, $34 \mathrm{p}$.

1978, Summary appraisals of the Nation's ground-water resources-Missouri Basin Region: U.S. Geological Survey Professional Paper 813-Q, 41 p.

Thayer, P. A., 1983, Relationship of porosity and permeability to petrology of the Madison Limestone and associated rocks in part of Montana, Nebraska, North Dakota, South Dakota, and Wyoming: U.S. Geological Survey Professional Paper 1273-C, 29 p.

Thorstenson, D. C., Fisher, W. D., and Croft, M. G., 1979, The geochemistry of the Fox Hillsbasal Hell Creek aquifer in southwestern North Dakota and northwestern South Dakota: Water Resources Research, v. 15, no. 6, p. 1479-1498.

Trimble, D. E., 1980, The geologic story of the Great Plains: U.S. Geological Survey Bulletin 1493, $55 \mathrm{p}$.

Unfer, Louis, Jr., 1951, Study of factors influencing the rank of Wyoming coals: Laramie, Wyo., University of Wyoming unpublished masters thesis, $54 \mathrm{p}$.

University of Wyoming, Black Thunder project research team, 1976, Black Thunder mine site, Campbell County, Wyoming: University of Wyoming, Final environmental assessment, 3 volumes.

U.S. Bureau of Land Management, 1974, Surface ownership, northern Great Plains resources program region: Denver Service Center, Colo., Map.

1978, State of Wyoming land status: U.S. Bureau of Land Management map, scale 1:1,000,000.

1979, Wyoming land use decisions, western Powder River basin area: U.S. Bureau of Land Management, Casper District Office report, $53 \mathrm{p}$.

1980, Wyoming land use decisions, eastern

Powder River basin area: U.S. Bureau of Land
Management, Casper District Office report, $14 \mathrm{p}$.

U.S. Bureau of Reclamation, 1959, Report on sediment control in upper Cheyenne River basin, South Dakota-Wyoming: U.S. Bureau of Reclamation, Huron, S.D. Project Office report, $80 \mathrm{p}$.

U.S. Department of Agriculture, 1962, Soil survey manual: U.S. Department of Agriculture Handbook 18, 487 p.

1975, Soil taxonomy: U.S. Department of Agriculture Handbook 436, 754 p.

U.S. Department of Commerce, 1981, 1978 census of agriculture: Bureau of the Census, State and County Data Part 50, Wyoming AC78-A-50, v. 1,267 p.

U.S. Department of the Interior, 1975, Proposed plan of mining and reclamation, Belle Ayr South mine, Amax Coal Company, Campbell County, Wyoming: U.S. Department of the Interior, Geological Survey (lead agency), Reston, Va., Final Environmental Impact Statement, variable pagination.

1976, Proposed plan of mining and reclamation, Cordero mine, Sun Oil Company coal lease W-8385, Campbell County, Wyoming: U.S. Department of the Interior, Geological Survey (lead agency), Reston, Va., Final Environmental Impact Statement, variable pagination.

1977a, Resource and potential reclamation evaluation, Bear Creek study area, West Moorhead Coalfield: U.S. Depart ment of the Interior, EMRIA Report no. 8, 259 p.

$1977 \mathrm{~b}$, Resource and potential reclamation evaluation, White Tail Butte study area, Little Powder River Coal Field: U.S. Department of the Interior, EMRIA Report no. 13, $112 \mathrm{p}$. $1977 \mathrm{c}$, Proposed mining and reclamation plan, Eagle Butte mine, Amax Coal Company coal lease W-0313773, Campbell County, Wyoming: U.S. Department of the Interior, Geological Survey (lead agency), Reston, Va., Final Environmental Impact Statement, variable pagination.

1977d, Proposed mining and reclamation plan, East Gillette mine, Kerr-McGee Corporation coal leases W-311810, W-312311, and W-313668, Campbell County, Wyoming: U.S. Department of the Interior, Geological Survey (lead agency), Reston, Va., Draft Environmental Impact Statement, variable pagination.

1979a, Proposed mining and reclamation 
plan, Pronghorn mine, Campbell County, Wyoming: U.S. Department of the Interior, Geological Survey (lead agency), Reston, Va., Final Environmental Impact Statement, variable pagination.

$1979 \mathrm{~b}$, Proposed mining and reclamation plan, Coal Creek mine, Campbell County, Wyoming: U.S. Department of the Interior, Geological Survey (lead agency), Reston, Va., Final Environmental Impact Statement, variable pagination.

1979c, Proposed mining and reclamation plan, Caballo mine, Campbell County, Wyoming: U.S. Department of the Interior, Geological Survey (lead agency), Reston, Va., Final Environmental Impact Statement, variable pagination.

1979d, Proposed development of coal resources in the eastern Powder River Basin, Wyoming: U.S. Department of the Interior, Bureau of Land Management (lead agency), Cheyenne, Wyo., Final Environmental Impact Statement, variable pagination.

1981a, Powder River regional coal: U.S. Department of the Interior, Bureau of Land Management (lead agency), Cheyenne, Wyo., Final Environmental Impact Statement, variable pagination.

1981b, Proposed mining and reclamation plan, Rojo Caballos mine, Campbell County, Wyoming: U.S. Department of the Interior, Office of Surface Mining Reclamation and Enforcement (lead agency), Denver, Colo., Final Environmental Impact Statement OSMEIS-3, variable pagination.

1982a, Proposed mining and reclamation plan, North Antelope mine, Campbell County, Wyoming: U.S. Department of the Interior, Office of Surface Mining Reclamation and Enforcement (lead agency), Denver, Colo., Draft Environmental Impact Statement OSMEIS-6, variable pagination.

1982b, Proposed mining and reclamation plan, Antelope mine, Converse County, Wyoming: U.S. Department of the Interior, Office of Surface Mining Reclamation and Enforcement (lead agency), Denver, Colo., Final Environmental Impact Statement OSM-EIS-5, variable pagination.

1983, Proposed mining and reclamation plan, North Rochelle mine, Campbell County, Wyoming: U.S. Department of the Interior, Office of Surface Mining Reclamation and En- forcement (lead agency), Denver, Colo., Final Environmental Impact Statement OSMEIS-9, variable pagination.

U.S. Department of the Interior and Montana Department of State Lands, 1980, Northern Powder River basin coal, Montana: U.S. Department of the Interior, Geological Survey, (lead agency), Reston, Va., Final Environmental Impact Statement, 4 volumes.

U.S. Department of the Interior, U.S. Department of Agriculture, and U.S. Interstate Commerce Commission, 1974, Proposed development of coal resources in the eastern Powder River coal basin of Wyoming: U.S. Department of the Interior, Bureau of Land Management (lead agency), Cheyenne, Wyo., Final Environmental Impact Statement, 6 volumes.

U.S. Environmental Protection Agency, 1976 [1977], Quality criteria for water, 1976: U.S. Environmental Protection Agency publication, $256 \mathrm{p}$.

1977, National interim primary drinking water regulations: U.S. Environmental Protection Agency Report, EPA-570/9-76-003, $159 \mathrm{p}$.

1979, National secondary drinking water regulations: Federal Register, v. 44 , no. 140 , July 19, p. 42195-42202.

U.S. Fish and Wildlife Service, 1978, 1978 Stream evaluation map, State of Wyoming: U.S. Fish and Wildlife Service Office of Biological Services, 1 sheet.

1980,1980 Stream evaluation map, State of Montana: U.S. Fish and Wildlife Service Office of Biological Services, 1 sheet.

U.S. Geological Survey, 1973, Land and coal ownership in the Gillette area, Wyoming: U.S. Geological Survey Miscellaneous Investigations Map I-848-B.

1974, Stripping coal deposits of the northern Great Plains, Montana, Wyoming, North Dakota, and South Dakota: U.S. Geological Survey Miscellaneous Field Studies Map MF-590, 1 sheet.

1975 , Plan of study of the hydrology of the Madison Limestone and associated rocks in parts of Montana, Nebraska, North Dakota, South Dakota, and Wyoming: U.S. Geological Survey Open-File Report 75-631, 37 p.

1976a, Hydrologic unit map-1974, State of Wyoming: U.S. Geological Survey map, scale 1:500,000.

1976b, Hydrologic unit map-1974, State of 
Montana: U.S. Geological Survey map, scale 1:500,000.

1977, National handbook of recommended methods for water-data acquisition, chapter 5-Chemical and physical quality of water and sediment: $193 \mathrm{p}$.

1979a, Land use and land cover, 1974-76, Gillette, Wyoming; South Dakota; Montana: U.S. Geological Survey Land Use Map L-77, scale 1:250,000.

$1979 \mathrm{~b}$, Land use and land cover, 1970-76, Hardin, Montana; Wyoming: U.S. Geological Survey Land Use Map L-78, scale 1:250,000. $1979 c$, Land use and land cover, 1974, Miles City, Montana; North Dakota: U.S. Geological Survey Land Use Map L-80, scale 1:250,000. 1979d, Land use and land cover, 1976, Newcastle, Wyoming; South Dakota; Nebraska: U.S. Geological Survey Land Use Map L-81, scale $1: 250,000$.

$1979 \mathrm{e}$, Plan of study for the Northern Great Plains regional aquifer-system analysis in parts of Montana, North Dakota, South Dakota, and Wyoming: U.S. Geological Survey Water Resources Investigations Report 79-34, $20 \mathrm{p}$.

1980a, Land use and land cover, 1976, Ekalaka, Montana; North Dakota; South Dakota: U.S. Geological Survey Land Use Map L-137, scale 1:250,000.

$1980 \mathrm{~b}$, Catalog of selected offices of the Office of Surface Mining, Bureau of Land Management, and Geological Survey relating to coal, 1981: U.S. Geological Survey Circular 840, $41 \mathrm{p}$.

1982, Land use and land cover and associated maps for Torrington, Wyoming; Nebraska: U.S. Geological Survey Open- File Report 82-4, scale 1:250,000.

1983a, Water-resources data for Wyoming, water year 1982: U.S. Geological Survey Water-Data Report WY-82-1, 504 p. (Annual series; reports for previous years published with similar titles.)

1983b, Water Resources data for Montana, water year 1982, v. 1., Hudson Bay basin and Missouri River basin: U.S. Geological Survey Water-Data Report MT-82-1, 553 p. (Annual series; reports for previous years published with similar titles.)

U.S. Office of Surface Mining, 1981a, Ground water model handbook: U.S. Office of Surface Mining Report H-D3004-021-81-1062D, 5 sec- tions with separate pagination.

1981b, Surface water model handbook: U.S. Office of Surface Mining Report H-D3004-021-81-1063D, 4 sections with separate pagination.

U.S. Public Health Service, 1962, Drinking water standards, 1962: U.S. Public Health Service Publication 956, $61 \mathrm{p}$.

U.S. Salinity Laboratory Staff, 1954, Diagnosis and improvement of saline and alkali soils: U.S. Department of Agriculture Handbook 60, $160 \mathrm{p}$.

U.S. Soil Conservation Service, 1977, Average annual precipitation in Montana based on 1941-1970 base period: Bozeman, Montana, U.S. Department of Agriculture, $13 \mathrm{p}$.

U.S. Water Resources Council, 1981, Guidelines for determining flood flow frequency [revised]: Hydrology Committee Bulletin 17B, 27 p., 14 appendixes with separate pagination.

Van Houten, F. B., 1964, Tertiary geology of the Beaver Rim area, Fremont and Natrona Counties, Wyoming: U.S. Geological Survey Bulletin 1164, 99 p.

Van Voast, W. A., 1974, Hydrologic effects of coal strip mining in southeastern MontanaEmphasis: One year of mining near Decker: Montana Bureau of Mines and Geology Bulletin 93, 24 p.

Van Voast, W. A., and Bremmer, J. M., 1976, Volatilization of sulfur from unamended and sulfate treated soils: Soil Biology Biochemistry, v. 8, p. 19-22.

Van Voast, W. A., Hedges, R. B., and McDermott, J. J., 1978, Hydrologic characteristics of coalmine spoils, southeastern Montana: Montana University Joint Water Resources Research Center Report 94, 34 p.

Ver Ploeg, A. J., 1982, Wyoming's oil and gas in dustry: Geological Survey of Wyoming Public Information Circular No. 17, 20 p.

Walker, F. K., 1980, Bibliography and index of U.S. Geological Survey publications relating to coal, January 1971 through June 1978: American Geological Institute publication, $64 \mathrm{p}$.

Wangsness, D. J., 1977, Physical, chemical, and biological relations of four ponds in the Hidden Water Creek strip-mine area, Powder River basin, Wyoming: U.S. Geological Survey Water-Resources Investigations Report 77-72, $48 \mathrm{p}$.

Wangsness, D. J., and Peterson, D. A., 1980, Behavioral and catastrophic drift of in 
vertebrates in two streams in northeastern Wyoming: U.S. Geological Survey Open-File Report 80-1101, 13 p.

Warner, D. A., 1947, Geology and ground-water resources of the Kaycee area, Wyoming: U.S. Geological Survey Open-File Report, 9 p.

Wells, D. K., 1982, Ground-water data from selected wells in alluvial aquifers, Powder River basin, northeastern Wyoming: U.S. Geological Survey Open-File Report 82-856, $35 \mathrm{p}$.

Wells, D. K., Busby, J. F., and Glover, K. C., 1979, Chemical analysis of water from the Minnelusa Formation and equivalents in the Powder River basin and adjacent areas, northeastern Wyoming: Wyoming State Engineer, Wyoming Water Planning Program Report no. $18,27 \mathrm{p}$.

Wendell, W. G., Glass, G. B., Breckenridge, R. M., Root, F. K., Lageson, David, and The Remote Sensing Lab, University of Wyoming, 1976, Johnson County, Wyoming; Geologic map atlas and summary of land, water and mineral resources: The Geological Survey of Wyoming County Series no. 4, 9 sheets.

Wesche, T. A., and Johnson, L. S., 1980, Aquatic biota and abiota of selected streams on Thunder Basin National Grassland, Wyoming: University of Wyoming Water Resources Research Institute report, $20 \mathrm{p}$.

Whitcomb, H. A., 1965, Ground-water resources and geology of Niobrara County, Wyoming, with a section on Chemical quality of the ground water, by T. R. Cummings: U.S. Geological Survey Water-Supply Paper 1788, $101 \mathrm{p}$.

Whitcomb, H. A., Cummings, T. R., and McCullough, R. A., 1966, Ground-water resources and geology of northern and central Johnson County, Wyoming: U.S. Geological Survey Water-Supply Paper 1806, 99 p.

Whitcomb, H. A., and Morris, D. A., 1964, Groundwater resources and geology of northern and western Crook County, Wyoming: U.S. Geological Survey Water-Supply Paper 1698, $92 \mathrm{p}$.

Wister, Owen, 1902, The Virginian: New York, Grosset and Dunlap (1929 ed., with permission of the Macmillan Co.), $434 \mathrm{p}$.
Wright, R. A., editor, 1978, The reclamation of disturbed arid lands: Albuquerque, University of New Mexico Press, 196 p.

Wyoming Department of Administration and Fiscal Control, 1981, Wyoming data handbook 1981: Wyoming Department of Administration and Fiscal Control, Division of Research and Statistics handbook, 5th edition, $201 \mathrm{p}$.

Wyoming Department of Economic Planning and Development, 1981a, Wyoming Mineral Development Monitoring System: Wyoming Department of Economic Planning and Development, Mineral Development Division report, $196 \mathrm{p}$. 1981b, Mining laws of Wyoming, 1980: The Geological Survey of Wyoming Public Information Circular 15, 34 sections, separate pagination (looseleaf).

Wyoming Department of Environmental Quality, 1982, Wyoming surface water classifications FY-82: Department of Environmental Quality, Water Quality Division report, $14 \mathrm{p}$.

Wyoming Office of the State Inspector of Mines, 1983, Annual report of the State Inspector of Mines of Wyoming for the year ending December 31, 1982: State of Wyoming (published annually since 1902).

Wyoming State Engineer's Office, 1976, Investigation of recharge to groundwater reservoirs of northeastern Wyoming (the Powder River basin): Old West Regional Commission report, $111 \mathrm{p}$.

Wyoming Water Planning Program, 1972, Water and related land resources of northeastern Wyoming: Wyoming State Engineer's Office, Wyoming Water Planning Program Report No. $10,209 \mathrm{p}$. 1973a, Wyoming's groundwater supplies: Wyoming State Engineer's Office information publication (27 unnumbered pages).

$1973 \mathrm{~b}$, The Wyoming framework water plan: Wyoming State Engineer's Office, Wyoming Water Planning Program report, 243 p.

Young, J. F., and Singleton, P. C., 1977, Wyoming general soil map: University of Wyoming Agricultural Experiment Station Research Journal, no. 117,40 p. 
